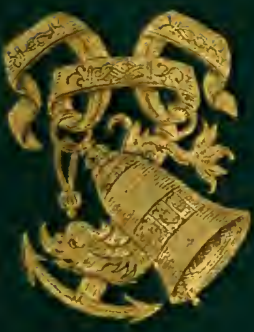




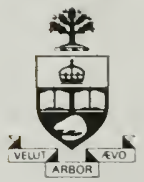

Presented to the

Prof. Robert Finch LIBRARY of the UNIVERSITY OF TORONTO by$$
\text { by }
$$ 
73 


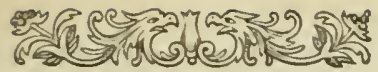

\section{OF THE ADVANCEMENT OF}

\section{LEARNING.}

ధ 
Digitized by the Internet Archive in 2009 with funding from University of Toronto 


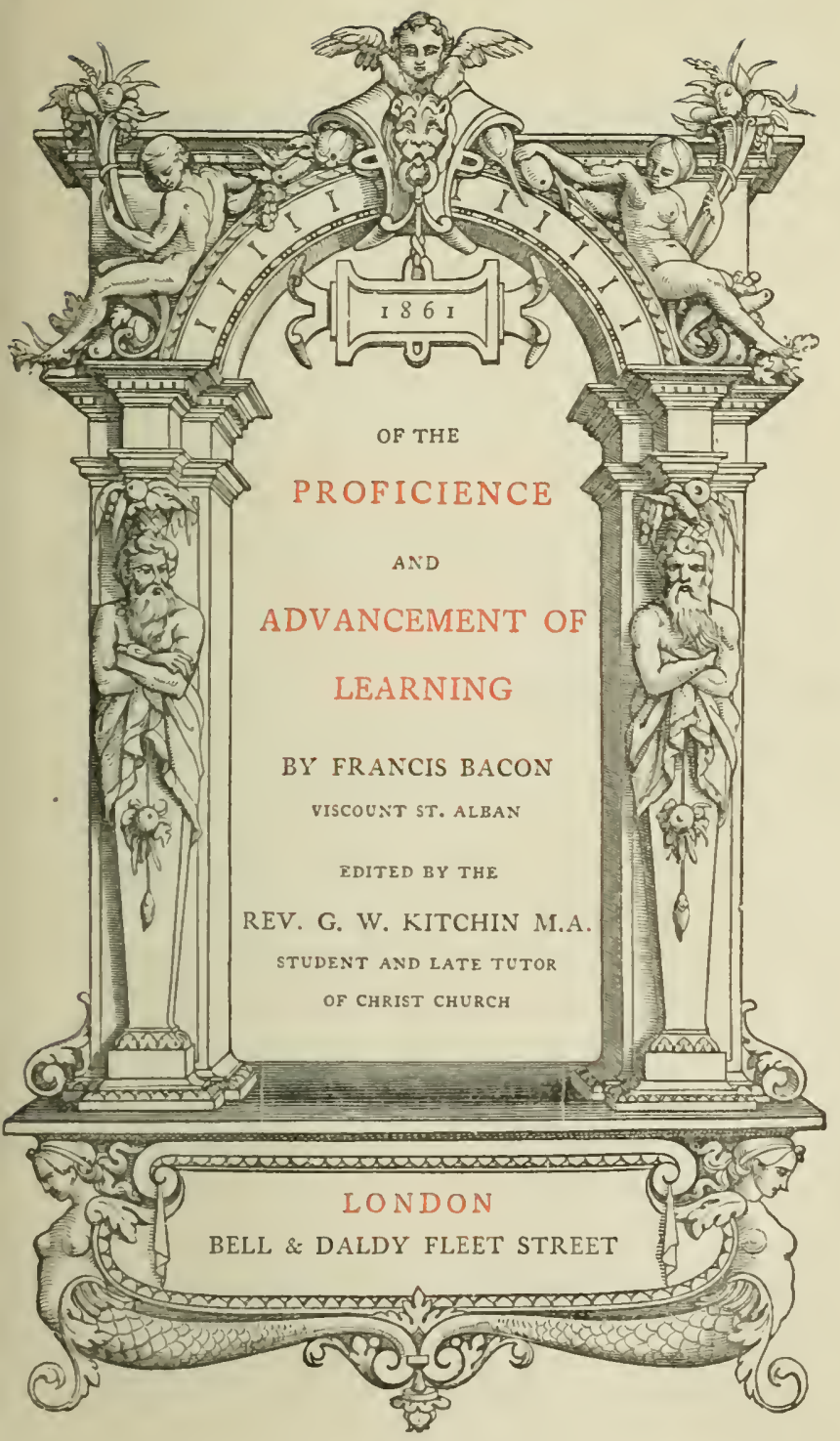





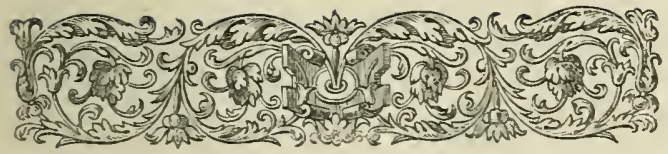

\section{P R E F A CE.}

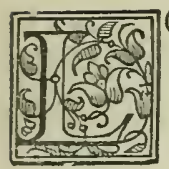

ORD BACON has given us his own eftimate of the value and pofition of the Advancement of Learning. "This writing," fays he, "feemeth to me, fi nunquam fallit imago, not much better than that noife or found which muficians make while they are tuning their infruments; which is nothing pleafant to hear, but yet is a caufe why the mufic is fweeter afterwards: fo have I been content to tune the inftruments of the Mufes, that they may play that have better hands." Wherein he errs in two oppofite ways: for, on the one fide, the book is nobler than the fenfelefs jargon to which he likens it; while, on the other, the muficians that have taken up the work have fcarcely fucceeded in playing harmoniouny together. He feems not to be aware of the intrinfic worth of the thoughts expreffed in every page, while he alfo feems to have imagined that a Millennium of 
Learning was about to begin, to which this book fhould be, as it were, the herald trumpet. Under fo almoft divine a fovereign as King James I. learning will furely be fortered and advanced. Controverfies in religion, he thinks, are all but worn out (and this on the eve of the great Puritan ftruggles and fuccefles!), and we thall have leifure to leave queftions of faith for the difcovery of the Laws of Nature. And yet, with all this, he does not difcern the value of mathematics, that branch of learning which was then making great advance, and was deftined to work wonders. He fcarcely cared to have an opinion on the "Copernican Theory" of Aftronomy. He never mentions his famous countryman Gilbert without a fneer, or at leaft a difparaging remark; though he was engaged on thofe difcoveries in magnetifm which have tended to enlarge in many ways the empire of man over Nature. He by no means emancipates himfelf thoroughly from the thraldom of the old fcholaftic fyftems. He regards Poetry as complete, requiring no farther development: and is not confcious that he is living with thofe who were above all others to be the pride of Englifh Literature, and who fhould labour in broad fields of Poetry, which had never yet been touched by mortal hand. In thefe and other 


\section{PREFACE.}

vii

fubjects the book is defective enough; yet, remembering all things, we muft marvel at the extraordinary breadth of knowledge and reading; the fertility of thought, and happinefs of expreffion; the complete arrangement of fubjects, and lucid order of the work, which fhow themfelves throughout. Nor did Bacon himfelf fail to fee the importance of his pioneer-book-otherwife he would not have expanded it fo fully as he has done in the Latin-tranflating it into that tongue that it might the more readily gain accefs to all lands, and be read by the learned in every place; and carefully expunging all paffages which might be diftafteful abroad, left the Roman Church fhould be offended with the accidents, and fo neglect the effence of his writings.

The frontifpiece of the original edition of the Novum Organum expreffes his feeling refpecting the Advancement. Between two pillars, the pillars of Hercules, the thip of learning fails forth upon a toffed fea, bound for lands as yet unvifited, to bring thence goodly ftore of new and precious merchandife. Behind her lie all thofe well-known fhores of knowledge, of which the Advancement gives the map and chart. They were, if we may fo fpeak, thofe Mediterranean lands which were the heart of the fourth or Roman Empire-trod- 
den by every foot of learned men : familiar even to children in knowledge. But beyond the ftraits is the great outer fea, and continents as yet unknown, to be explored by painful daring, and deftined to increafe the wealth of the world in a million ways. The old empire hould give place to the new : juft as the Mediterranean ceafed to be all-important, when once the boldnefs of Bartholomew Diaz had fhown an eafier pathway to the wealth of India; and the infpired dreams of Columbus had been realized by the difcovery of new continents acrofs the main.

The Advancement of Learning was, therefore, the firft work in Bacon's great feries. That feries he ftyled the "Inftauratio Magna," and under the firft head of "Partitiones Scientiarum" he placed this book. It was to be a chart of the lands already difcovered and known; fo as to direct the attention of the adventurer without lors of time or labour to thofe parts which had not yet been explored. Then came the Novum Organum; a "Method" or inftrument by means of which men hould arrive at thefe novelties:- the thip, in fact, of his frontifpiece, on board of which (to ufe his own motto), -

Multi pertranfibunt, et augebitur fcientia.

After that, the "Inftauratio" was to be compofed 
of fucceffive works, ending with a "Philofophia fecunda," or complete fyßtem of knowledge. This, however, he felt muft be left to pofterity.

Whoever, therefore, defires to acquaint himfelf with Bacon's philofophical works muft begin with the Advancement, referring to the $D e$ Augmentis Scientiarum from time to time. Then, having thus become familiar with the ftyle of the great thinker, he will be able to go on to that noble work, the Novum Organum; wherein are contained the feeds of marvellous wifdom, of knowledge which has grown and flourifhed to this day; and has affected for ever the courfe and fortunes of learning.

In preparing this edition of the Advancement of Learning for the general reader, I have aimed at three things - a faithful text, full verification of quotations, and brevity and fimplicity of notes.

As to the firft of thefe matters, there was but little difficulty. The variations in the text are very few, and very unimportant. Wherever it was poffible, I have followed the edition of 1605 , leaving myfelf little fcope for conjecture.

As to the next point, I had the work already done for me, to a great extent, both in the edition of Mr. Markby, and in the De Augmentis of the great Ellis and Spedding edition. I have been able here and there to fupply miffing references, 
and have carefully verified thofe already found for me.

But with refpect to notes, it is unneceffary that I fay more than that their aim is to be as unobtrufive as poffible, and that I hope they may be ufeful.

Lafty, I fubjoin a brief analyfis of the work. 


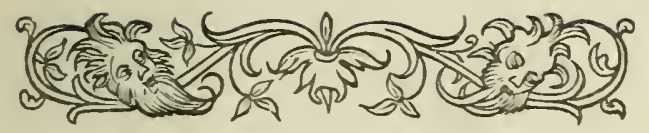

\section{A N A L Y S IS.}

Book I. (Preliminary.) Briefly removes the prejudices againft Learning, with proofs, divine and human, of its dignity. (Corresponds with De Augmentis, Bk. I.)

Book II. (On the main fubject.) Commended to kings as nurfing fathers. (De Augm. ii. prof.)

Learning is twofold-Divine and Human. Divine poltponed. (De Augm. ii.)

HUMAN LEARNING is threefold-I. Hiftory (which anfwers to the Memory). II. Poefy (to Imagination). III. Philofophy (to Reafon).

I. Hiftory.

I. Natural.

(a.) Of Creatures.

(b.) Marvels.

2. Civil.

(c.) Arts.

(a.) Memorials.

(b.) Antiquities.

(c.) Perfect Hiftory.

i. Chronicles.

a. Ancient.

b. Modern.

ii. Lives.

iii. Narrations.

iv. Annals.

v. Cofmography.

3. Ecclefiaftical.

(a.) Of the Church.

(b.) Of Prophecy.

(c.) Of Providence.

4. Literary, or appendices to Hiftory. 
II. Poefy. (Herein is no deficiency.)

I. Narrative.

2. Reprefentative.

3. Allufive or Parabolical.

III. Philofophy. (De Augm. iii.)

1. Divine (or Natural Theology, not $=$ Divinity).

2. Natural

Difcufion of the Philofophia Prima.

i. Science.

(i.) Phyfical (of material and efficient caufes).

(2.) Metaphyfical (of formal and final caufes), and under Metaphyfical come Mathematics, pureand mixed.

ii. Prudence.

(r.) Experimental.

(2.) Philofophical.

(3.) Magical.

3. Human. (De Augm. iv.)

i. Segregate (i.e. of individual men) of (a.) Body and (b.) Mind, firt confidered in combination with refpect to (a.) Difcovery and ( $\beta$.$) Impreffion, and then feparately;$

(a.) Body.

(a.) Medicine.

(B.) Colmetic Art.

( $\gamma$.) Athletics.

(ঠ.) Senfual Arts.

(b.) Mind.

(a.) Its Nature, (with two Appendices on Divination and Fafcination.)

(B.) Its Functions. (De Augm. v.)

A. Intellectual, whofe Arts are four.

(i.) Of Invention.

(a.) Of Arts (deficient).

(B.) Of Speech. 
(ii.) Of Judgment, whofe Methods are-

(a.) Of Direction (Analytics).

(b.) Of Caution (Elenches).

(iii.) of Cuftody.

(a.) By Writing.

(b.) By Memory.

(a.) Prenotion.

(в.) Emblem.

(iv.) of Tradition. (De Augm. vi.) .

(a.) Its organ-fpeech, or writing (grammar).

(b.) Its method (Logic).

(c.) Its illuftration (Rhetoric).

(With appendices).

B. Moral. (De Augm, vii.)

(i.) Of the Nature of Good (omitting the fummum bonum, as belonging to another life).

(1.) Private.

(a.) Active.

(b.) Paffive.

(a.) Confervative.

(B.) Perfective.

(2.) Relative.

(a.) Of man as citizen.

(b.) Of man as focial being.

(ii) Of Moral Culture.

ii. Congregate. (De Augm. viii.)

(a.) In Converfation.

(b.) In Negociation (with rules for felf-advancement).

(c.) In Government (with notes on Laws). 
In Conclufion. (De Augm. ix.)

Theology-refers to man's Reafon and Will.

Difcuffed as to-

x. The nature (or manner) of the Revelation

(a.) Its Limits.

(b.) Its Sufficiency.

(c.) Its Acquifition.

2. The thing revealed.

(a.) Matter of Belief.

(a.) Faith.

(B.) Manners.

(b.) Matter of Service.

(a.) Liturgy.

(B.) Government.

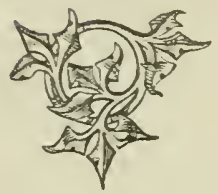




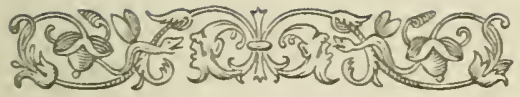

THE TWO BOOKS OF FRANCIS BACON.

Of the Proficience and

Advancement of Learning,

Divine and Human.

To the King.

ค 



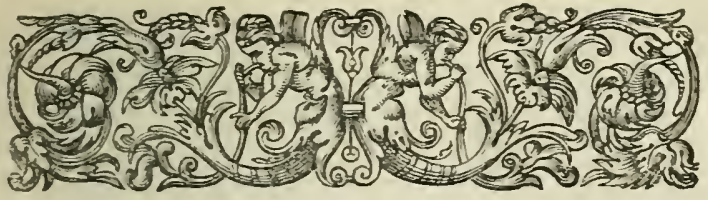

THE FIRST BOOK OF FRANCIS BACON:

Of the Proficience and

\section{Advancement of Learning \\ Divine and Human.}

To the King.

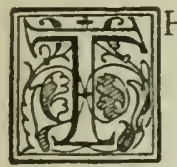

HERE were under the Law, excellent King, both daily Sacrifices and freeDe Aug. Sc. I. will Offerings; the one proceeding upon ordinary obfervance, the other upon a devout cheerfulnefs: in like manner there belongeth to Kings from their fervants both tribute of duty and prefents of affection. In the former of thefe I hope I thall not live to be wanting, according to my moft humble duty, and the good pleafure of your Majefty's employments: for the latter, I thought it more refpective to make choice of fome oblation, which might rather refer to the propriety and excellency of your individual perfon, than to the bufinels of your crown and ftate.

1 Where the divifions occur in the Latin, I propofe to place references in the margins. 


\section{ADVANCEMENT OF LEARNING.}

Wherefore, reprefenting your Majefty many times unto my mind, and beholding you, not with the inquifitive eye of prefumption, to difcover that which the Scripture telleth me is infrutable, ${ }^{2}$ but with the obfervant eye of duty and admiration; leaving afide the other parts of your virtue and fortune, I have been touched, yea, and poffeffed with an extreme wonder at thofe your virtues and faculties, which the Philofophers call intellectual; the largenefs of your capacity, the faithfulners of your memory, the fwiftnefs of your apprehenfion, the penetration of your judgment, and the facility and order of your elocution: and I have often thought, that of all the perfons living that I have known, your Majefty were the beft inftance to make a man of Plato's opinion, ${ }^{3}$ that all knowledge is but remembrance, and that the mind of man by nature knoweth all things, and hath but her own native and original notions ${ }^{4}$ (which by the Atrangenefs and darknefs of this tabernacle of the body are fequeftered) again revived and reftored: fuch a light of nature I have obferved in your Majefty, and fuch a readinefs to take flame and blaze from the leaft occafion prefented, or the leaft fpark of another's knowledge delivered. And as the Scripture faith of the wifent king, That bis beart was as the fands of the fea $;^{5}$ which though

2 Prov. xxv. 3 .

${ }^{3}$ Phædo, i. 72 . I have ufed in all references to Plato the paging of the ed. Steph.

4 The edition $x 605$ has motions, a word which miffes the point -editions 1629 and 1633 read notions.

3 I Kings iv. 29. 
it be one of the largeft bodies, yet it confifteth of the fmalleft and fineft portions; fo hath God given your Majefty a compofition of underftanding admirable, being able to compafs and comprehend the greateft matters, and neverthelefs to touch and apprehend the leaft; whereas it fhould feem an impoffibility in nature for the fame infrument to make itfelf fit for great and fmall works. And for your gift of fpeech, I call to mind what Cornelius Tacitus faith of Auguftus Cæfar: Augufto profluens, et qua principem deceret, eloquentia fuit. ${ }^{6}$ For, if we note it well, fpeech that is uttered with labour and difficulty, or fpeech that favoureth of the affectation of art and precepts, or fpeech that is framed after the imitation of fome pattern of eloquence, though never fo excellent; all this hath fomewhat fervile, and holding of the fubject But your Majefty's manner of fpeech is indeed prince-like, flowing as from a fountain, and yet ftreaming and branching itfelf into nature's order, full of facility and felicity, imitating none, and inimitable by any. And as in your civil eftate there appeareth to be an emulation and contention of your Majefty's virtue with your fortune; a virtuous difpofition with a fortunate regiment; a virtuous expectation (when time was) of your greater fortune, with a profperous poffeffion thereof in the due time; a virtuous obfervation of the laws of marriage, with moft bleffed and happy fruit of marriage; a virtuous and moft Chriftian defire of peace, with a fortunate inclination in your neigh-

6 Tac. Annal. xiii. 3 . 


\section{ADVANCEMENT OF LEARNING.}

Learning, how difcredited.

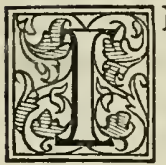

$\mathrm{N}$ the entrance to the former of thefe, to clear the way, and as it were to make filence, to have the true teitimonies concerning the dignity of Learning to be better heard, without the interruption of tacit objections, I think good to deliver it from the difcredits and difgraces which it hath received; all from ignorance; but ignorance feverally difguifed, appearing fometimes in the zeal and jealoufy of Divines; fometimes in the feverity and arrogancy of Politiques; and fometimes in the errors and imperfections of learned men themfelves.

By Divines.

I. I hear the former fort fay, that Knowledge is of thofe things which are to be accepted of with great limitation and caution; that the afpiring to overmuch knowledge was the original temptation and fin whereupon enfued the fall of man; that Knowledge hath in it fomewhat of the ferpent, and therefore where it entereth into a man it makes him fwell; Scientia inflat: ${ }^{10}$ that Salomon gives a cenfure, $T$ bat there is no end of making books, and that much reading is wearinefs of the fief $; 11$ and again in another place, That in spacious knowledge there is much contriftation, and that he that increafeth knowledge increafeth anxiety $;^{12}$ that St. Paul gives a caveat, That we be not fpoiled through vain philofophy $;^{13}$ that expe-

10 I Cor, viii. I.

11 Eccl. xii. 12.

12 Eccl. i. I 8.

13 Col. ii. 8. 


\section{BOOK I.}

rience demonftrates how learned men have been arch-heretics, how learned times have been inclined to atheifm, and how the contemplation of fecond caufes doth derogate from our dependence upon God, who is the firft caufe.

To difcover then the ignorance and error of Their obthis opinion, and the mifunderftanding in the jections angrounds thereof, it may well appear thefe men do not obferve or confider that it was not the pure knowledge of nature and univerfality, a knowledge by the light whereof man did give names unto other creatures in Paradife, ${ }^{14}$ as they were brought before him, according unto their proprieties, which gave the occafion to the fall: but it was the proud knowledge of good and evil, with an intent in man to give law unto himfelf, and to depend no more upon God's commandments, which was the form of the temptation. Neither is it any quantity of knowledge, how great foever, that can make the mind of man to fwell; for nothing can fill, much lefs extend the foul of man, but God and the contemplation of God; and therefore Salomon, fpeaking of the two principal fenfes of inquifition, the eye and the ear, affirmeth that the eye is never fatisfied with feeing, nor the ear with hearing $;^{15}$ and if there be no fulnefs, then is the continent greater than the content: $f_{0}$ of knowledge itfelf, and the mind of man, whereto the fenfes are but reporters, he defineth likewife in thefe words, placed after that Kalendar or Ephemerides, which he maketh of the diverfities of

it See Gen. ii. and iii.

15 Eccl. i. 8. 


\section{ADVANCEMENT OF LEARNING.}

times and feafons for all actions and purpofes; and concludeth thus: God hath made all things beautiful, or decent, in the true return of their feafons: Alfo be hath placed the world in man's heart, yet cannot man find out the work which God worketh from the beginning to the end ${ }^{16}$ declaring not obfcurely, that God hath framed the mind of man as a mirror or glass, capable of the image of the univerfal world, and joyful to receive the impreffion thereof, as the eye joyeth to receive light; and not only delighted in beholding the variety of things and viciffitude of times, but raifed alfo to find out and difcern the ordinances and decrees, which throughout all thofe changes are infallibly obferved. And although he doth infinuate that the fupreme or fummary law of nature, which he calleth the work which God worketh from the beginning to the end, is not poffible to be found out by man; yet that doth not derogate from the capacity of the mind, but may be referred to the impediments, as of thortnefs of life, ill conjunction of labours, ill tradition of knowledge over from hand to hand, and many other inconveniences, whereunto the condition of man is fubject. For that nothing parcel of the world is denied to man's inquiry and invention, he doth in another place rule over, when he faith, The fpirit of man is as the lamp of God, wherewith be Searcheth the inwardne/s of all fecrets. ${ }^{17}$ If then fuch be the capacity and receipt of the mind of man, it is manifeft that there is no danger at all in the proportion or quantity 
of knowledge, how large foever, left it fhould make it fwell or out-compals itfelf; no, but it is merely the quality of knowledge, which, be it in quantity more or lefs, if it be taken without the true corrective thereof, hath in it fome nature of venom or malignity, and fome effects of that venom, which is ventofity or fwelling. This corrective fpice, the mixture whereof maketh Knowledge fo fovereign, is Charity, which the Apoftle immediately addeth to the former claufe: for fo he faith, Knowledge bloweth up, but Charity buildeth $u p$; not unlike unto that which he delivereth in another place: If I spake, faith he, with the tongues of men and angels, and bad not sharity, it were but as a tinkling cymbal; ${ }^{18}$ not but that it is an excellent thing to fpeak with the tongues of men and angels, but becaufe, if it be fevered from charity, and not referred to the good of men and mankind, it hath rather a founding and unworthy glory, than a meriting and fubftantial virtue. And as for that cenfure of Salomon, concerning the excefs of writing and reading books, and the anxiety of fpirit which redoundeth from knowledge; and that admonition of St. Paul, That we be not feduced by vain philofopby; let thofe places be rightly underftood, and they do indeed excellently fet forth the true bounds and limitations, whereby human knowledge is confined and circumfribed; and yet without any fuch contracting or coarctation, but that it may comprehend all the univerfal nature of things; for thefe limitations are

18 I Cor. xiii. I. 
three: the firft, That we do not fo place our felicity in knowledge, as we forget our mortality: the fecond, That we make application of our knowledge, to give ourfelves repofe and contentment, and not diftafte or repining: the third, That we do not prefume by the contemplation of nature to attain to the myfteries of God. For as touching the firlt of there, Salomon doth excellently expound himfelf in another place of the fame book, where he faith:19 I faw well that knowledge recedeth as far from ignorance as light doth from darknefs; and that the wife man's eyes keep watch in his bead, whereas the fool roundeth about in darknefs: but withal I learned, that the fame mortality involveth them both. And for the fecond, certain it is, there is no vexation or anxiety of mind which refulteth from knowledge otherwife than merely by accident; for all knowledge and wonder (which is the feed of knowledge) is an impreffion of pleafure in itfelf : but when men fall to framing conclufions out of their knowledge, applying it to their particular, and miniftering to themfelves thereby weak fears or vaft defires, there groweth that carefulnefs and trouble of mind which is fpoken of : for then knowledge is no more Lumen ficcum, whereof Heraclitus the profound ${ }^{\circ}$ faid, Lumen ficcum optima

19 Eccl. ii. I 3,14 .

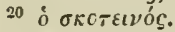

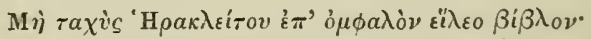

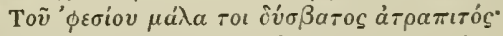

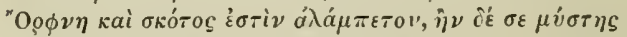

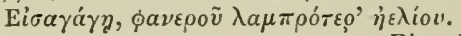

Diog. Laert. ix. 
anima; but it becometh Lumen madidum, or maceratum, being fteeped and infufed in the humours of the affections. ${ }^{21}$ And as for the third point, it deferveth to be a little ftood upon, and not to be lightly paffed over: for if any man fhall think by view and inquiry into thefe fenfible and material things to attain that light, whereby he may reveal unto himfelf the Nature or Will of God, then indeed is he fpoiled by vain philofophy: for the contemplation of God's creatures and works produceth (having regard to the works and creatures themfelves), knowledge, but having regard to God, no perfect knowledge, but wonder, which is broken knowledge. And therefore it was molt aptly faid by one of Plato's fchool, ${ }^{22}$ That the fenfe of man carrieth a refemblance with the fun, which, as we fee, openeth and revealeth all the terreftrial globe; but then again it obfcureth and concealeth the fars and celeftial globe: fo doth the fenfe difcover natural things, but it darkeneth and Jutteth up divine. And hence it is true that it hath proceeded, that divers great learned men have been heretical, whilft they have fought to fly up to the fecrets of the Deity by the waxen wings of the fenfes. And as for the conceit that too much knowledge fhould incline a man to Atheifm, ${ }^{9.3}$ and that the ignorance of fecond caufes thould make a more devout dependence upon God, which is the firft caufe;

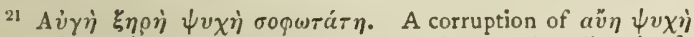
бофшта́т $\eta$. (See note in Ellis and Spedding's ed.) The phrafe occurs in Stobæus, cf. Ritter, Hift. Pbilos. vol. i. Heraclitus.

${ }^{22}$ Philo Jud. de Samn.

23 See Bacon's Eljays-On Atbeijm. 
firft, it is good to ank the queftion which Job afked of his friends: IVill you lie for God, as one man will do for another, to gratify bim? ? For certain it is that God worketh nothing in nature but by fecond caufes : and if they would have it otherwife believed, it is mere impofture, as it were in favour towards God; and nothing elfe but to offer to the Author of 'Truth the unclean facrifice of a lie. But farther, it is an affured truth, and a conclufion of experience, that a little or fuperficial knowledge of Philofophy may incline the mind of man to Atheifm, but a farther proceeding therein doth bring the mind back again to Religion: for in the entrance of Philofophy, when the fecond caufes, which are next unto the fenfes, do offer themfelves to the mind of man, if it dwell and ftay there it may induce fome oblivion of the higheft caufe; but when a man paffeth on farther, and feeth the dependence of caufes, and the works of Providence; then, according to the allegory of the poets, he will eafily believe that the highe ft link of nature's chain muft needs be tied to the foot of Jupiter's chair. ${ }^{25}$ To conclude therefore, let no man upon a weak conceit of fobriety or an illapplied moderation think or maintain, that a man can fearch too far, or be too well ftudied in the book of God's word, or in the book of God's works; divinity or philofophy: but rather let men endeavour an endlefs progrefs or proficience in both; only let men beware that they apply both to charity, and not to fwelling; to ufe, and not to

21 Job xiii. 7. ${ }^{25}$ Hom. Il. viii. 19. 
oftentation; and again, that they do not unwifely mingle or confound thefe learnings together.

2. And as for the difgraces which Learning re- By Politiceiveth from Politiques, they be of this nature; cians. that Learning doth foften men's minds, and makes them more unapt for the honour and exercife of arms; that it doth mar and pervert men's difpofitions for matter of government and policy, in making them too curious and irrefolute by variety of reading, or too peremptory or pofitive by frictnefs of rules and axioms, or too immoderate and overweening by reafon of the greatnefs of examples, or too incompatible and differing from the times by reafon of the diffimilitude of examples; or at leaft, that it doth divert men's travails from action and bufinefs, and bringeth them to a love of leifure and privatenefs; and that it doth bring into ftates a relaxation of difcipline, whilft every man is more ready to argue than to obey and execute. Out of this conceit, Cato, ${ }^{26}$ furnamed the Cenfor, one of the wifert men indeed that ever lived, when Carneades the philofopher came in embaffage to Rome, and that the young men of Rome began to flock about him, being allured with the fweetnefs and majefty of his eloquence and learning, gave coun$\mathrm{fel}$ in open fenate that they fhould give him his difpatch with all fpeed, left he fhould infect and enchant the minds and affections of the youth, and at unawares bring in an alteration of the manners and cuftoms of the ftate. ${ }^{27}$ Out of the fame conceit or humour did Virgil, turning his pen to the 26 See Pliny, Nat. Hiff. vii. 3 I. 27 Plut. vit. Cat. 


\section{$14 A D V A N C E M E N T$ OF LEARNING.}

advantage of his country, and the difadvantage of his own profeffion, make a kind of feparation between policy and government, and between arts and fciences, in the verfes fo much renowned, attributing and challenging the one to the Romans, and leaving and yielding the other to the Grecians :-

Tu regere imperio populos, Romane, memento,

Hæ tibi erunt artes, \&c. ${ }^{28}$

So likewife we fee that Anytus, the accufer of Socrates, laid it as an article of charge and accufation againft him, that he did, with the variety and power of his difcourfes and difputations, withdraw young men from due reverence to the laws and cuftoms of their country, and that he did profers a dangerous and pernicious fcience, which was, to make the worfe matter feem the better, and to fupprefs truth by force of eloquence and fpeech. ${ }^{\circ 9}$

Theirob- (I.) But thefe, and the like imputations, have jections re- rather a countenance of gravity than any ground
futed. of juftice : for experience doth warrant, that both in perfons and in times, there hath been a meeting and concurrence in Learning and Arms, flourifhing and excelling in the fame men and the fame ages. For, as for men, there cannot be a better nor the like inftance, as of that pair, Alexander the Great and Julius Caefar the Dictator; whereof the one was Ariftotle's fcholar in philofophy, and the other was Cicero's rival in eloquence: or if any man had rather call for fcholars that were great

${ }^{28}$ Virg. AEn. vi, 85 I. 29 Plato, Apol. Soc., i. 19, 24. 
generals, than generals that were great fcholars, let him take Epaminondas the Theban, or Xenophon the Athenian; whereof the one was the firft that abated the power of Sparta, and the other was the firft that made way to the overthrow of the monarchy of Perfia. And this concurrence is yet more vifible in times than in perfons, by how much an age is a greater object than a man. For both in Egypt, Affyria, Perfia, Græcia, and Rome, the fame times that are moft renowned for arms, are likewife moft admired for learning, fo that the greateft authors and philofophers, and the greateft captains and governors have lived in the fame ages. Neither can it otherwife be: for as in man the ripeners of ftrength of the body and mind cometh much about an age, fave that the ftrength of the body cometh fomewhat the more early : ${ }^{30}$ fo in ftates, Arms and Learning, whereof the one correfpondeth to the body, the other to the foul of man, have a concurrence or near fequence in times.

(2.) And for matter of Policy and Government, that learning fhould rather hurt, than enable thereunto, is a thing very improbable: we fee it is accounted an error to commit a natural body to empiric phyficians, which commonly have a few pleafing receipts whereupon they are confident and adventurous, but know neither the caufes of difeafes, nor the complexions of patients, nor peril of

$30 \mathrm{Cf}$. Ariftotle, Rhet. ii. 14. 4, where he fays that the body reaches perfection at the age of $35(7 \times 5)$, and the mind at 49 $(7 \times 7$. 


\section{ADVANCEMENT OF LEARNING.}

accidents, nor the true method of cures : we fee it is a like error to rely upon advocates or lawyers, which are only men of practice and not grounded in their books, who are many times eafily furprifed when matter falleth out befides their experience, to the prejudice of the caufes they handle: fo by like reafon it cannot be but a matter of doubtful confequence if ftates be managed by empiric Statefmen, not well mingled with men grounded in learning. But contrariwife, it is almoft without inftance contradictory, that ever any government was difaftrous that was in the hands of learned governors. ${ }^{31}$ For howfoever it hath been ordinary with politic men to extenuate and difable learned men by the names of Pedantes; yet in the records of time it appeareth, in many particulars, that the governments of princes in minority (notwithftanding the infinite difadvantage of that kind of ftate) have neverthelefs excelled the government of princes of mature age, even for that reafon which they feek to traduce, which is, that by that occafion the ftate hath been in the hands of Pedantes; for fo was the ftate of Rome for the firft five years, which are fo much magnified, during the minority of Nero, in the hands o Seneca, a Pedanti ; fo it was again, for ten years' fpace or more, during the minority of Gordianus the younger, with great applaufe and contentation in the hands of Mifitheus, a Pedanti: fo was it before that, in the minority of Alexander Severus, in like happinefs, in hands not much unlike, by

31 See Plato, Rep. v. 473 . 
reafon of the rule of the women, who were aided by the teachers and preceptors. Nay, let a man look into the government of the bifhops of Rome, as, by name, into the government of Pius Quintus, and Sextus Quintus, in our times, who were both at their entrance efteemed but as pedantical ${ }^{32}$ friars, and he fhall find that fuch popes do greater things, and proceed upon truer principles of eftate, than thofe which have afcended to the papacy from an education and breeding in affairs of eftate and courts of princes; for although men bred in learning are perhaps to feek in points of convenience and accommodating for the prefent, which the Italians call Ragioni di ftato, whereof the fame Pius Quintus could not hear fpoken with patience, terming them inventions againft religion and the moral virtues; yet on the other fide, to recompenfe that, they are perfect in thofe fame plain grounds of religion, juftice, honour, and moral virtue, which if they be well and watchfully purfued, there will be feldom ufe of thofe other, no more than of phyfic in a found or well-dieted body. Neither can the experience of one man's life furnifh examples and precedents for the events of one man's life: for, as it happeneth fometimes that the grandchild, or other defcendants, refembleth the anceftor more than the fon; fo many times occurrences of prefent times may fort better with ancient examples than with thofe of the latter or immediate times: and laftly, the wit of one man can no

32 Edit. 1605 , prejudicial. The Latin has "fraterculis rerum imperitis." 
more countervail learning than one man's means can hold way with a common purfe.

3. And as for thofe particular feducements, or indifpofitions of the mind for policy and government, which Learning is pretended to infinuate; if it be granted that any fuch thing be, it muft be remembered withal, that Learning miniftereth in every of them greater ftrength of medicine or remedy than it offereth caufe of indifpofition or infirmity. For if by a fecret operation it make men perplexed and irrefolute, on the other fide by plain precept it teacheth them when and upon what ground to refolve; yea, and how to carry things in fufpenfe without prejudice, till they refolve; if it make men pofitive and regular, it teacheth them what things are in their nature demonftrative, and what are conjectural, and as well the ufe of diftinctions and exceptions, as the latitude of principles and rules. If it miflead by difproportion or diffimilitude of examples, it teacheth men the force of circumftances, the errors of comparifons, and all the cautions of application; fo that in all thefe it doth rectify more effectually than it can pervert. And thefe medicines it conveyeth into men's minds much more forcibly by the quicknefs and penetration of examples. For let a man look into the errors of Clement the feventh, fo lively defcribed by Guicciardine, ${ }^{32}$ who ferved under him, or into the errors of Cicero, painted out by his own pencil in his Epiftles to Atticus, and he will fly apace from being irrefolute. Let him look into the errors of 


\section{$B O O K I$.}

Phocion, and he will beware how he be obftinate or inflexible. Let him but read the fable of Ixion, ${ }^{33}$ and it will hold him from being vaporous or imaginative. Let him look into the errors of Cato the fecond, and he will never be one of the Antipodes, to tread oppofite to the prefent world. ${ }^{34}$

4. And for the conceit that Learning fhould difpofe men to leifure and privatenefs, and make men flothful; it were a ftrange thing if that which accuftometh the mind to a perpetual motion and agitation thould induce flothfulnefs: whereas contrariwife it may be truly affirmed, that no kind of men love bufinefs for itfelf but thofe that are learned; for other perfons love it for profit, as a hireling, that loves the work for the wages; or for honour, as becaufe it beareth them up in the eyes of men, and refrefheth their reputation, which otherwife would wear; or becaufe it putteth them in mind of their fortune, and giveth them occafion to pleafure and difpleafure; or becaufe it exercifeth fome faculty wherein they take pride, and fo entertaineth them in good humour and pleafing conceits towards themfelves; or becaufe it advanceth any other their ends. So that, as it is faid of untrue valours, that fome men's valours are in the eyes of them that look on; fo fuch men's induftries are in the eyes of others, or at leaft in regard of their own defignments: only learned men love bufinefs as an action according to nature, as agreeable to health of mind as exercife is to health of body, taking pleafure in the action itfelf, and not

33 Pind. Pytb. ii. 2r, feq. 34 Cic. ad Att. ii. I. 
in the purchafe: fo that of all men they are the moft indefatigable, if it be towards any bufinefs which can hold or detain their mind.

And if any man be laborious in reading and ftudy and yet idle in bufinefs and action, it groweth from fome weakners of body or foftnefs of fpirit; fuch as Seneca fpeaketh of: Quidam tam funt umbratiles, ut putent in turbido effe quicquid in luce ef $;^{35}$ and not of Learning: well may it be that fuch a point of a man's nature may make him give himfelf to Learning, but it is not learning that breedeth any fuch point in his nature.

5. And that Learning fhould take up too much time or leifure; I anfwer, the moft active or bufy man that hath been or can be, hath, no queftion, many vacant times of leifure, while he expecteth the tides and returns of bufinefs (except he be either tedious and of no difpatch, or lightly and unworthily ambitious to meddle in things that may be better done by others:) and then the queftion is, but how thefe ipaces and times of leifure fhall be filled and fpent ; whether in pleafures or in ftudies; as was well anfwered by Demofthenes to his adverfary $Æ$ chines, that was a man given to pleafure, and told him, That bis orations did fmell of the lamp: Indeed, (faid Demofthenes) there is a great difference between the things that you and I do by lamp-light. ${ }^{36}$ So as no man need doubt that Learning will expulfe bufinefs, but rather it will keep

35 Seneca, Epift. 3 . quoted from Pomponius, "Quidam adeo in latebras refugerunt, ut" \&-c.

${ }^{86}$ Plutarch. Libanius, Vit. Demofih. (Ed. Dindorf, p. 6.) Told of Pytheas, not of Aifchines. 
and defend the poffeffion of the mind againft idlenefs and pleafure, which otherwife at unawares may enter to the prejudice of both.

6. Again, for that other conceit that Learning Thould undermine the reverence of laws and government, it is affuredly a mere depravation and calumny, without all hadow of truth. For to fay that a blind cuftom of obedience fhould be a furer obligation than duty taught and underftood, it is to affirm, that a blind man may tread furer by a guide than a feeing man can by a light. And it is without all controverfy, that learning doth make the minds of men gentle, generous, maniable, ${ }^{3 i}$ and pliant to government; whereas ignorance makes them churlifh, thwart, and mutinous: and the evidence of time doth clear this affertion, confidering that the moft barbarous, rude, and unlearned times have been moft fubject to tumults, feditions, and changes.

7. And as to the judgment of Cato the Cenfor, he was well punithed for his blafphemy againft Learning, in the fame kind wherein he offended; for when he was paft threefcore years old, he was taken with an extreme defire to go to fchool again, and to learn the Greek tongue, to the end to perufe the Greek authors; which doth well demonftrate that his former cenfure of the Grecian learning was rather an affected gravity, than according to the inward fenfe of his own opinion. And as for Virgil's verfes, though it pleafed him to brave the 37 The edition of 1605 reads amiable, that of 1633 maniable. The latter word anfwers beft to the Latin, artes-teneros reddunt, Sequaces, cereos. 


\section{ADVANCEMENT OF LEARNING.}

world in taking to the Romans the art of empire, and leaving to others the art of fubjects; yet fo much is manifeft that the Romans never afcended to that height of empire, till the time they had afcended to the height of other arts. For in the time of the two firft Cæars, which had the art of government in greateft perfection, there lived the beft poet, Virgilius Maro; the beft hiftoriographer, Titus Livius; the beft antiquary, Marcus Varro; and the beft, or fecond orator, Marcus Cicero, that to the memory of man are known. As for the accufation of Socrates, the time muft be remembered when it was profecuted; which was under the Thirty Tyrants, the moft bafe, bloody, and envious perfons that have governed; which revolution of ftate was no fooner over, but Socrates, whom they had made a perfon criminal, was made a perfon heroical, and his memory accumulate with honours divine and human; and thofe difcourfes of his which were then termed corrupting of manners, were after acknowledged for fovereign medicines of the mind and manners, and fo have been received ever fince till this day. Let this, therefore, ferve for anfwer to Politiques, which in their humorous feverity, or in their feigned gravity, have prefumed to throw imputations upon Learning; which redargution neverthelefs (fave that we know not whether our labours may extend to other ages) were not needful for the prefent, in regard of the love and reverence towards Learning, which the example and countenance of two fo learned Princes, Queen Elizabeth, and your Majefty, being as Caf- 
tor arid Pollux, Lucida fidera, ${ }^{38}$ ftars of excellent light and moft benign influence, hath wrought in all men of place and authority in our nation.

III. Now therefore we come to that third fort of difcredit or diminution of credit that groweth unto Learning from learned men themfelves, which commonly cleaveth fafteft : it is either from their fortune; or from their manners; or from the nature of their ftudies. For the firft, it is not in their power; and the fecond is accidental; the third only is proper to be handled. But becaufe we are not in hand with true meafure, but with popular eftimation and conceit, it is not amifs to fpeak fomewhat of the two former. The derogations therefore which grow to Learning from the fortune or condition of learned men, are either in refpect of fcarcity of means, or in refpect of privatenefs of life and meannefs of employments.

I. (a) Concerning want, and that it is the cafe of This objeclearned men ufually to begin with little, and not to grow rich fo faft as other men by reafon they convert not their labours chiefly to lucre and increafe: it were good to leave the common place By learned men themfelves. tion examined and refuted: I. As to theirmeanin commendation of poverty to fome friar to handle, to whom much was attributed by Machiavel in this point; when he faid, That the kingdom of the clergy had been long before at an end, if the reputation and reverence towards the poverty of friars bad not borne out the fcandal of the fuperfuities and excefes of bijhops and prelates. ${ }^{39}$ So a man might fay that the

${ }^{33}$ Hor, Carm. iii. 2.

39 Mach. Difc. fspra Tita. Liv. iii. l., fpeaking of the Francifcan and Dominican orders. 


\section{$24 A D V A N C E M E N T$ OF LEARNING.}

felicity and delicacy of princes and great perfons had long fince turned to rudenefs and barbarifm, if the poverty of Learning had not kept up civility and honour of life: but without any fuch advantages, it is worthy the obfervation what a reverend and honoured thing poverty was for fome ages in the Roman ftate, which neverthelefs was a fate without paradoxes. For we fee what Titus Livius faith in his introduction: Ceterum aut me amor negotii fufcepti fallit, aut nulla unquam refpublica nec major, nec fanctior, nec bonis exemplis ditior fuit; nec in quam tam fera avaritia luxuriaque immigraverint; nec ubi tantus ac tam diu paupertati ac parfimonice bonos fuerit. ${ }^{40}$ We fee likewife, after that the ftate of Rome was not itfelf, but did degenerate, how that perfon that took upon him to be counfellor to Julius Cæfar after his victory where to begin his reftoration of the ftate, maketh it of all points the moft fummary to take away the eftimation of wealth: Verum hac, et omnia mala pariter cum bonore pecunice definent; fi neque magiftratus, neque alia vulgo cupienda, venalia erunt. ${ }^{41}$ To conclude this point, as it was truly faid, that $R$ uboreftrirtutis color, though fometime it come from vice $;^{42}$ fo it may be fitly faid that Paupertas ef virtutis fortuna, though fometime it may proceed from mifgovernment and accident. Surely Salomon hath pronounced it both in cenfure, Qui feftinat ad divitias non erit infons; ${ }^{43}$ and in precept; Buy the truth, and fell it not; and fo of wifdom and know-

10 Livii Praf.

1 Epift. I. ad C. Caes. de Rep.ord.

\$2 Diog. Cyn. ap. Laert. vi. 54.

43 Prov, xxviii. 22 . 
ledge; ${ }^{44}$ judging that means were to be fpent upon Learning, and not Learning to be applied to means.

$(\beta)$ And as for the privatenefs, or obfcurenefs (as it may be in vulgar eftimation accounted) of life of contemplative men; it is a theme fo common to extol a private life, not taxed with fenfuality and floth, in comparifon [with] and to the difadvantage of a civil life, for fafety, liberty, pleafure, and dignity, or at leaft freedom from indignity, as no man handleth it but handleth it well; fuch a confonancy it hath to men's conceits in the expreffing, and to men's confents in the allowing. This only I will add, that learned men forgotten in ftates and not living in the eyes of men, are like the images of Caffius and Brutus in the funeral of Junia: of which not being reprefented, as many others were, Tacitus faith, Eo ipjo prafulgebant, quod non vifebantur. ${ }^{45}$

(y) And for meannefs of employment, that which is moft traduced to contempt is that the government of youth is commonly allotted to them; which age, becaufe it is the age of leaft authority, it is transferred to the difefteeming of thofe employments wherein youth is converfant, and which are converfant about youth. But how unjuft this traducement is (if you will reduce things from popularity of opinion to meafure of reafon) may appear in that we fee men are more curious what they put into a new veffel than into a veffel feafoned; and what mould they lay about a young

4 Prov. xxiii. 23.

is Tac. Ann. iii. 76. ad fin. 


\section{ADVANCEMENT OF LEARNING.}

plant than about a plant corroborate; fo as the weakeft terms and times of all things ufe to have the beft applications and helps. And will you hearken to the Hebrew rabbins? Your young men hall fee vifions, and your old men frall dream dreams; ${ }^{46}$ fay they ${ }^{47}$ youth is the worthier age, for that vifions are nearer apparitions of God than dreams. And let it be noted, that howfoever the condition ${ }^{46}$ of life of Pedantes hath been fcorned upon theatres, as the ape of tyranny; and that the modern loofenefs or negligence hath taken no due regard to the choice of fchoolmafters and tutors; yet the ancient wifdom of the beft times did always make a juft complaint, that ftates were too bufy with their laws and too negligent in point of education: which excellent part of ancient difcipline hath been in fome fort revived of late times by the colleges of the Jefuits; of whom, although in regard of their fuperftition I may fay, Quo meliores, eo deteriores; yet in regard of this, and fome other points concerning human learning and moral matters, I may fay, as Agefilaus faid to his enemy Pharnabazus, Talis quum fis, utinam nofter effes. ${ }^{49}$ And thus much touching the difcredits drawn from the fortunes of learned men.

1I. As to their manners.
2. As touching the manners of learned men, it is a thing perfonal and individual : and no doubt there be amongtt them, as in other profeffions,

46 Joel ii. 28.

47 Ed. I 629 and I 633 read "fay the."

$48 \mathrm{Ed}$. 1605 reads "conditions... hath," I633 reads "conditions... have."

49 Conference of Agefilaus and Pharnabazus. Plut. Vit. Ages. 


\section{$B O O K I$.}

of all temperatures : but yet fo as it is not without truth, which is faid, that Abeunt fudia in mores, ${ }^{50}$ ftudies have an influence and operation upon the manners of thofe that are converfant in them.

(a) But upon an attentive and indifferent review, I for my part cannot find any difgrace to Learning can proceed from the manners of learned men not inherent ${ }^{51}$ to them as they are learned; except it be a fault (which was the fuppofed fault of Demorthenes, Cicero, Cato the fecond, Seneca, and many more) that, becaufe the times they read of are commonly better than the times they live in, and the duties taught better than the duties practifed, they contend fometimes too far to bring things to perfection, and to reduce the corruption of manners to honefty of precepts, or examples of too great height. And yet hereof they have caveats enough in their own walks. For Solon, when he was afked whether he had given his citizens the beft laws, anfwered wifely, $r_{e a}$ of fuch as they would receive: ${ }^{50}$ and $\mathrm{Plato}$, finding that his own heart could not agree with the corrupt manners of his country, refufed to bear place or office, faying, That a man's country was to be ufed as bis parents were, that is, with bumble perfuafions, and not with contefations. ${ }^{53}$ And Cærar's counfellor put in the

so Ovid, Ep. xv. 83 .

31 De Augm. has nullum occurrit dedecus literis $\epsilon x$ litteratorum moribus, quatenus funt literati, adbarens, which explains it. The not before inberent goes with cannut according to the rule of double negative, as it prevailed in early Englifh writers.

${ }_{52}$ Plutarch, Vit. Solon.

53 Plato, Epift. Z. iii. 331. 


\section{ADVANCEMEN'T OF LEARNING.}

fame caveat, Non ad vetera inftituta revocans que jampridem corruptis moribus ludibrio funt: ${ }^{54}$ and Cicero noteth this error directly in Cato the fecond, when he writes to his friend Atticus; Cato optime fentit, fed nocet interdum reipublice; loquitur enim tanquam in reipublicâ Platonis, non tanquam in face Romuli.55 And the fame Cicero doth excufe and expound the philofophers for going too far, and being too exact in their prefcripts, when he faith, Ifti ipfi praceptores virtutis et magiftri, videntur fines officiorum paulolongius quam natura vellet protulife, ut cum ad ultimum animo contendifemus, ibi tamen, ubi oportet, confifteremus: 56 and yet himfelf might have faid, Monitis fum minor ip ee meis ; ${ }^{5 i}$ for it was his own fault, though not in fo extreme a degree.

( $\beta$ ) Another fault likewife much of this kind hath been incident to learned men; which is, that they have efteemed the prefervation, good, and honour of their countries or mafters before their own fortunes or fafeties. For fo faith Demofthenes unto the Athenians; If it pleafe you to note it, my counfels unto you are not fucb whereby I fhould growe great among $f$ you, and you become little among/t the Grecians: but they be of that nature, as they are fometimes not good for me to give, but are always good for you to follow. ${ }^{58}$ And fo Seneca, after he had confecrated that Quinquennium Neronis ${ }^{59}$ to

54 Sall. Epift. de Rep. ord.

56 Cic. pro Mur. xxxi. 65.

58 Demolth. Cbers. 187 , ad finem.

59 The 2uinquennium Neronis refers to the firt five years of Nero's reign, during which he was under Seneca's influence. 


\section{$B O O K I$.}

the eternal glory of learned governors, held on his honeft and loyal courfe of good and free counfel, after his mafter grew extremely corrupt in his government. Neither can this point otherwife be ; for Learning endueth men's minds with a true fenfe of the frailty of their perfons, the cafualty of their fortunes, and the dignity of their foul and vocation: fo that it is impoffible for them to efteem that any greatnefs of their own fortune can be a true or worthy end of their being and ordainment; and therefore are defirous to give their account to God, and fo likewife to their mafters under God (as kings and ftates that they ferve) in thefe words; Ecce tibi lucrefeci, and not Ecce mibi lucrefeci;60 whereas, the corrupter fort of mere Politiques, that have not their thoughts eftablifhed by learning in the love and apprehenfion of duty, nor never look abroad into univerfality, do refer all things to themfelves, and thruft themfelves into the centre of the world, as if all lines fhould meet in them and their fortunes; never caring in all tempefts what becomes of the thip of eftates, fo they may fave themfelves in the cockboat of their own fortune: whereas men that feel the weight of duty and know the limits of felf love, ufe to make good their places and duties, though with peril ; and if they fand in feditious and violent alterations, it is rather the reverence which many times both adverfe parts do give to honefty, than any verfatile advantage of their own carriage. But for this point of tender fenfe and faft obligation of duty

co Matt. xxv, 20. 


\section{ADVANCEMENT OF LEARNING.}

which learning doth endue the mind withal, howfoever fortune may tax it, and many in the depth of their corrupt principles may defpife it, yet it will receive an open allowance, and therefore needs the lefs difproof or excufation.

( $\gamma$ ) Another fault incident commonly to learned men, which may be more properly defended than truly denied, is, that they fail fometimes in applying themfelves to particular perfons: which want of exact application arifeth from two caufes; the one, becaufe the largenefs of their mind can hardly confine itfelf to dwell in the exquifite obfervation or examination of the nature and cuftoms of one perfon: for it is a fpeech for a lover, and not for a wife man: Satis magnum alter alteri theatrum fumus. ${ }^{61}$ Neverthelefs I fhall yield, that he that cannot contract the fight of his mind as well as difperfe and dilate it, wanteth a great faculty. But there is a fecond caufe, which is no inability, but a rejection upon choice and judgment. For the honeft and juft bounds of obfervation by one perfon upon another, extend no farther but to underftand him fufficiently, whereby not to give him offence, or whereby to be able to give him faithful counfel, or whereby to ftand upon reafonable guard and caution in refpect of a man's felf. But to be fpeculative into another man to the end to know how to work him, or wind him, or govern him, proceedeth from a heart that is double and cloven and not entire and ingenuous; which as in friendthip it is want of integrity, fo towards princes or

${ }^{61}$ A faying of Epicurus. Seneca, Epiff. Mor. i. 7 . 
fuperiors is want of duty. For the cuftom of the Levant, which is that fubjects do forbear to gaze or fix their eyes upon princes, ${ }^{62}$ is in the outward ceremony barbarous, but the moral is good: for men ought not by cunning and bent obfervations to pierce and penetrate into the hearts of kings, which the Scripture hath declared to be infcrutable. ${ }^{63}$

(d) There is yet another fault (with which I will conclude this part) which is often noted in learned men, that they do many times fail to obferve decency and difcretion in their behaviour and carriage, and commit errors in fmall and ordinary points of action, fo as the vulgar fort of capacities do make a judgment of them in greater matters by that which they find wanting in them in fmaller. But this confequence doth often deceive men, for which I do refer them over to that which was faid by Themiftocles, arrogantly and uncivilly being applied to himfelf out of his own mouth, but, being applied to the general ftate of this queftion, pertinently and juftly; when, being invited to touch a lute, he faid, He could not fiddle, but be could make a fmall town a great fate. ${ }^{64}$ So, no doubt, many may be well feen in the paffages of government and policy, which are to feek in little and punctual occafions. I refer them alfo to that which Plato faid of his mafter Socrates, whom he compared to the gallipots of apothecaries, which on the outfide had apes and owls and antiques, but
62 Herod. I. 99.
of Plutarch, Vit. Tbemift, ad init.
63 Prov. xxv. 3 . 


\section{ADVANCEMENT OF LEARNING.}

contained within fovereign and precious liquors and confections; acknowledging that to an external report he was not without fuperficial levities and deformities, but was inwardly replenifhed with excellent virtues and powers. ${ }^{65}$ And fo much touching the point of manners of learned men.

But in the mean time I have no purpofe to give allowance to fome conditions and courfes bafe and unworthy, wherein divers profeffors of learning have wronged themfelves and gone too far; fuch as were thofe trencher Philofophers which in the later age of the Roman ftate were ufually in the houfes of great perfons, being little better than folemn parafites; of which kind, Lucian maketh a merry defcription of the philofopher that the great lady took to ride with her in her coach, and would needs have him carry her little dog, which he doing officioufly and yet uncomely, the page fcoffed and faid, That be doubted, the philofopher of a Stoic would turn to be a Cynic. ${ }^{60}$ But above all the reft, the grofs and palpable flattery, whereunto many not unlearned have abafed and abufed their wits and pens, turning, as Du Bartas faith, ${ }^{6}{ }_{i}$ Hecuba into Helena, and Fauftina into Lucretia, hath moft diminifhed the price and eftimation of learning. Neither is the moral ${ }^{68}$ dedication of books and writings, as to patrons, to be commended : for that books, fuch as are worthy the name of books,

65 Plat. Conv. iii. 2 I 5 , where the thought is prefent, though the exact fimilitude is wanting.

66 Lucian. de Merc. Cond., 33, 34.

67 See Bethulian's Refcue, buok v.

"Tous ces efprits dont la voix futtereufe

Change Hícube en Hilène, et Fauftine en Ioucrècr."

68 Moral, here cuftcmary. 
ought to have no patrons but truth and reafon. And the ancient cuftom was to dedicate them only to private and equal friends, or to entitle the books with their names: or if to kings and great perfons, it was to fome fuch as the argument of the book was fit and proper for: but thefe and the like courfes may deferve rather reprehenfion than defence.

Not that I can tax or condemn the morigeration or application of learned men to men in fortune. For the anfwer was good that Diogenes made to one that anked him in mockery, How it came to pafs that philofophers were the followers of rich men, and not rich men of philofophers? He anfurered foberly, and yet fharply, Becaufe the one fort knew what they bad need of, and the other did not. ${ }^{69}$ And of the like nature was the anfwer which Ariftippus made, when having apetition to Dionyfius, and no ear given to him, he fell down at his feet; whereupon Dionyfius ftaid, and gave him the hearing, and granted it ; and afterward fome perfon, tender on the behalf of philofophy, reproved Ariftippus that he would offer the profeffion of philofophy fuch an indignity, as for a private fuit to fall at a tyrant's feet: but he anfwered, It was not his fault, but it was the fault of Dionyfius, that bad bis ears in bis feet.io Neither was it accounted weaknefs, but difcretion in him that would not difpute his beft with Adrianus Cæafar; excufing himfelf, That it was reafon to yield to bim

69 Diog. Laert. Vit. Arifippi, ii. 69 ; the anfwer was given by Ariftippus. 70 Ibid. ii. 79. 
34 ADVANCEMENT OF LEARNING.

that commanded thirty legions.71 Thefe and the like applications, and ftooping to points of neceffity and convenience, cannot be difallowed; for though they may have fome outward bafenefs, yet in a judgment truly made they are to be accounted fubmiffions to the occafion, and not to the perfon.

As to their follies.

3. Now I proceed to thofe errors and vanities which have intervened amongit the ftudies themfelves of the learned, which is that which is principal and proper to the prefent argument; wherein my purpofe is not to make a juftification of the errors, but by a cenfure and feparation of the errors to make a juftification of that which is good and found, and to deliver that from the afperfion of the other. For we fee that it is the manner of men to fcandalize and deprave that which retaineth the ftate ${ }^{i 2}$ and virtue, by taking advantage upon that which is corrupt and degenerate: as the heathens in the primitive Church ufed to blemifh and taint the Chriftians with the faults and corruptions of heretics. But neverthelefs I have no meaning at this time to make any exact animadverfion of the errors and impediments in matters of learning, which are more fecret and remote from vulgar opinion, but only to fpeak unto fuch as do fall under or near unto a popular obfervation.

There be therefore chiefly three vanities in ftudies, whereby learning hath been moft traduced.

71 Spartianus, Vit. Adriani, $\S$ I5. The excufe was made by Favorinus.

$72 \mathrm{Had}$ Bacon been accuftomed to ufe the then modern word its, it is probable he would have ufed it here. As it is, "the ftate and virtue " muft mean its pure and right condition. 


\section{BOOK $I$.}

For thore things we do efteem vain, which are either falfe or frivolous, thofe which either have no truth or no ufe: and thofe perfons we efteem vain, which are either credulous or curious; and curiofity is either in matter or words: fo that in reafon, as well as in experience, there fall out to be thefe three diftempers, as I may term them, of learning: the firft, fantaftical learning; the fecond, contentious learning; and the laft, delicate learning; vain imaginations, vain altercations, and vain affectations; and with the laft I will begin. (a) Martin Luther, conducted no Folly in doubt by a higher providence, but in difcourfe of vain words. rearon ${ }^{73}$ finding what a province he had undertaken againt the bifhop of Rome and the degenerate traditions of the church, and finding his own folitude, being no ways aided by the opinions of his own time, was enforced to awake all antiquity, and to call former times to his fuccours to make a party againft the prefent time. So that the ancient authors, both in divinity and in humanity, which had long time flept in libraries, began generally to be read and revolved. This by confequence did draw on a neceflity of a more exquifite travail in the languages original, wherein thofe authors did write, for the better underftanding of thofe authors, and the better advantage of prefling and applying their words. And thereof grew again a delight in their manner of ftyle and phrafe, and an admiration of that kind of writing; which was much furthered

73 Difcourfe of reafon; a proper logical term. Cf. Sanderfon, Ars Log. in. i. 
and precipitated by the enmity and oppofition that the propounders of thofe primitive but feeming new opinions had againft the fchoolmen; whowere generally of the contrary part, and whofe writings were altogether in a different ftyle and form; taking liberty to coin and frame new terms of art to exprefs their own fenfe, and to avoid circuit of fpeech, without regard to the purenefs, pleafantnefs, and, as I may call it, lawfulnefs of the phrafe or word. And again, becaufe the great labour that ${ }^{74}$ then was with the people, (of whom the Pharifees were wont to fay, Execrabilis ifta turba, qua non novit legem $)^{75}$ for the winning and perfuading of them, there grew of neceffity in chief price and requeft eloquence and variety of difcourfe, as the fitteft and forcibleft accefs into the capacity of the vulgar fort : fo that thefe four caufes concurring, the admiration of ancient authors, the hate of the fchoolmen, the exact ftudy of languages, and the efficacy of preaching, did bring in an affectionate ftudy of eloquence and copie of fpeech, which then began to flourifh. This grew fpeedily to an excefs; for men began to hunt more after words than matter; more after the choicenefs of the phrafe, and the round and clean compofition of the fentence, and the fweet falling of the claufes, and the varying and illuftration of their works with tropes and figures, than after the weight of matter, worth of fubject, foundnefs of argument, life of invention or depth of judgment. Then grew the flowing and watery

74 Ed. 1629 and 1633 omit that; but becaufe here=becaufe of. 75 John vii. 10. 
vein of Oforius ${ }^{76}$ the Portugal bifhop, to be in price. Then did Sturmius fpend fuch infinite and curious pains upon Cicero the Orator, and Hermogenes the Rhetorician, befides his own books of Periods and Imitation, and the like. Then did Car of Cambridge, and Afcham with their lectures and writings almoft deify Cicero and Demofthenes, and allure all young men that were fudious, unto that delicate and polifhed kind of learning. Then did Erafmus take occafion to make the fcoffing Echo: Decem annos confumpfi in legendo Cicerone; and the Echo anfwered in Greek, "OVE, Afine. ${ }^{i 7}$ Then grew the learning of the fchoolmen to be utterly defpifed as barbarous. In fum, the whole inclination and bent of thofe times was rather towards copie than weight.

Here, therefore, is the firft diftemper of learning, when men ftudy words and not matter; whereof, though I have reprefented an example of late times, yet it hath been and will be fecundum majus et minus in all time. And how is it poffible but this thould have an operation to difcredit learning, even with vulgar capacities, when they fee learned men's works like the firft letter of a patent, or limned book; which though it hath large flourifhes, yet is but a letter? It feems to me that Pygmalion's frenzy is a good emblem or portraiture of this vanity : 78 for words are but the images of matter; and except they have life of reafon and invention, to fall in love with them is all one as to fall in love with a picture.

76 Bithop of Silves, died 1580 .

77 Collog. between Fuvenis and Echo. ${ }^{78}$ Ovid, Mitam. x. 243. 


\section{$3^{8}$ ADVANCEMEN'T OF LEARNING.}

But yet notwithftanding it is a thing not haftily to be condemned, to clothe and adorn the obfcurity even of Philofophy itfelf with fenfible and plaufible elocution. For hereof we have great examples in Xenophon, Cicero, Seneca, Plutarch, and of Plato alfo in fome degree; and hereof likewife there is great ufe: for furely, to the fevere inquifition of truth and the deep progrefs into philofophy, it is fome hindrance; becaufe it is too early fatisfactory to the mind of man, and quencheth the defire of further fearch, before we come to a juft period. But then if a man be to have any ufe of fuch knowledge in civil occafions, of conference, counfel, perfuafion, difcourfe, or the like; then fhall he find it prepared to his hands in thofe authors which write in that manner. But the excers of this is fo juftly contemptible, that as Hercules, when he faw the image of Adonis, Venus' minion, in a temple, faid in difdain, Nil Jacri es ; 79 fo there is none of Hercules' followers in learning, that is, the more fevere and laborious fort of inquirers into truth, but will defpife thofe delicacies and affectations, as indeed capable of no divinenefs. And thus much of the firft difeafe or diftemper of learning.

Folly in ( $\beta$ ) The fecond which followeth is in nature vain matter. worfe than the former: for as fubitance of matter is better than beauty of words, fo contrariwife vain matter is worfe than vain words: wherein it feemeth the reprehenfion of St. Paul was not only proper for thofe times, but prophetical for the times following; and not only refpective to

79 Theocr. v. 2. (fchol.) or Erafmi Adag. 
divinity, but extenfive to all knowledge: Devita profanas vocum novitates, et oppofitiones falf nominis cientic. ${ }^{80}$ For he affigneth two marks and badges of fufpected and falfified fcience: the one, the novelty and ftrangenefs of terms; the other, the ftrictners of pofitions, which of neceffity doth induce oppofitions, and fo queftions and altercations. Surely, like as many fubftances in nature which are folid do putrify and corrupt into worms; fo it is the property of good and found knowledge to putrify and diffolve into a number of fubtle, idle, unwholefome, and, as I may term them, vermiculate queftions, which have indeed a kind of quicknefs and life of fpirit, but no foundnefs of matter or goodnefs of quality. This kind of degenerate learning did chiefly reign amongft the Schoolmen : ${ }^{81}$ who having fharp and ftrong wits, and abundance of leifure, and fmall variety of reading, but their wits being fhut up in the cells of a few authors (chiefly Ariftotle their dictator) as their perfons were thut up in the cells of monafteries and colleges, and knowing little hiftory, either of nature or time, did out of no great quantity of matter and infinite agitation of wit fpin out unto thofe laborious webs of learning which are extant in their books. ${ }^{82}$ For the wit and mind of man, if it work upon matter, which is the contemplation of the creatures of God, worketh according to the ftuff, and is limited thereby ; but if it work upon itfelf, as the fpider worketh his

80 I Tim. vi. 20.

8I For his judgment-a harh one-on the Schoolmen, fee the Nov. Org. i. 71.

82 See Hallam, Hift. of Lit. vol. i. init. $18-23$. 
web, then it is endlefs, and brings forth indeed cobwebs of learning, admirable for the finenefs of thread and work, but of no fubftance or profit.

This fame unprofitable fubtilty or curiofity is of two forts; either in the fubject itfelf that they handle, when it is a fruitlefs fpeculation or controverfy, (whereof there are no fmall number both in Divinity and Philofophy) or in the manner or method of handling of a knowledge, which amongtt them was this; upon every particular pofition or affertion to frame objections, and to thofe objections, folutions; which folutions were for the moft part not confutations, but diftinctions : whereas indeed the ftrength of all fciences is, as the ftrength of the old man's fagot, in the band. For the harmony of a fcience, fupporting each part the other, is and ought to be the true and brief confutation and fuppreffion of all the fmaller fort of objections. But, on the other fide, if you take out every axiom, as the fticks of the fagot, one by one, you may quarrel with them, and bend them, and break them at your pleafure: fo that, as was faid of Seneca, Verborum minutiis rerum frangit pondera; ${ }^{83}$ fo a man may truly fay of the fchoolmen, 2uaftionum minutiis fientiarum frangunt foliditatem. For were it not better for a man in a fair room to fet up one great light or branching candleftick of lights, than to go about with a fmall watch candle into every corner? And fuch is their method, that refts not fo much upon evidence of truth proved by arguments, au-

${ }^{83}$ Rerum pondera minutifimis fententiis fregit.-Quint. de Inft. Orat. X. I. 
thorities, fimilitudes, examples, as upon particular confutations and folutions of every fcruple, cavillation, and objection; breeding for the molt part one queftion as faft as it folveth another; even as in the former refemblance, when you carry the light into one corner, you darken the reft; fo that the fable and fiction of Scylla feemeth to be a lively image of this kind of philofophy or knowledge; which was transformed into a comely virgin for the upper parts; but then

Candida fuccinctam la-trantibus inguina monftris : ${ }^{84}$

fo the generalities of the fchoolmen are for a while good and proportionable; but then, when you defcend into their diftinctions and decifions, inftead of a fruitful womb for the ufe and benefit of man's life, they end in monftrous altercations and barking queftions. So as it is not poffible but this quality of knowledge muft fall under popular contempt, the people being apt to contemn truth upon occafion of controverfies and altercations, and to think they are all out of their way which never meet; and when they fee fuch digladiation about fubtilties, and matters of no ufe or moment, they eafily fall upon that judgment of Dionyfius of Syracufe, Verba ifla funt fenum otioforum. ${ }^{35}$

Notwithftanding, certain it is that if thofe Schoolmen to their great thirft of truth and unwearied travail of wit had joined variety and univerfality of reading and contemplation, they had proved excellent lights, to the great advancement 84 Virg. Ecl. vi. 75 . s5 Diog. Laert. iii. 18. (Vit. Platonis.) 


\section{ADVANCEMENT OF LEARNING.}

of all learning and knowledge: but as they are, they are great undertakers indeed, and fierce with dark keeping: but as in the inquiry of the divine truth, their pride inclined to leave the oracle of God's word, and to vanifh in the mixture of their own inventions; fo in the inquifition of nature, they ever left the oracle of God's works, and adored the deceiving and deformed images which the unequal mirror of their own minds, or a few received authors or principles did reprefent unto them. And thus much for the fecond difeafe of learning.

Folly in untruth.

(y) For the third vice or difeafe of learning, which concerneth deceit or untruth, it is of all the reft the fouleft; as that which doth deftroy the effential form of knowledge, which is nothing but a reprefentation of truth: for the truth of being and the truth of knowing are one, differing no more than the direct beam and the beam reflected. This vice therefore brancheth itfelf into two forts; delight in deceiving, and aptnefs to be deceived; impofture and credulity; which, although they appear to be of a diverfe nature, the one feeming to proceed of cunning and the other of fimplicity, yet certainly they do for the moft part concur: for, as the verfe noteth,

\section{Percontatorem fugito, nam garrulus idem eft, ${ }^{66}$}

an inquifitive man is a prattler; fo, upon the like reafon, a credulous man is a deceiver: as we fee it in fame, that he that will eafily believe rumours,

${ }^{66}$ Hor. Ep. I. xviii. 69. 
will as eafily augment rumours, and add fomewhat to them of his own; which Tacitus wifely noteth, when he faith, Fingunt fimul creduntque :87 fo great an affinity hath fiction and belief.

This facility of credit and accepting or admitting things weakly authorized or warranted, is of two kinds according to the fubject: for it is either a belief of hiftory, (as ${ }^{88}$ the lawyers fpeak, matter of fact); or elfe of matter of art and opinion. As to the former, we fee the experience and inconvenience of this error in ecclefiaftical hiftory; which hath too eafily received and regiftered reports and narrations of miracles wrought by martyrs, hermits, or monks of the defert, and other holy men, and their relics, fhrines, chapels, and images : which though they had a paffage for a time by the ignorance of the people, the fuperftitious fimplicity of fome, and the politic toleration of others holding them but as divine poefies; yet after a period of time, when the mift began to clear up, they grew to be efteemed but as old wives' fables, impoftures of the clergy, illufions of fpirits, and badges of Antichrift, to the great fcandal and detriment of religion.

So in natural hiftory, we fee there hath not been that choice and judgment ufed as ought to have been; as may appear in the writings of Plinius, Cardanus, ${ }^{89}$ Albertus, ${ }^{90}$ and divers of the Arabians,

87 Tac. Hift. i. 5 I.

\&5 I have here followed the reading of Ed. 1605 .

89 Cardan-born in Pavia, I 501 -wrote about 122 works on Phyfics, Mathematics, Aftronomy, Aftrology, Medicine, Ethics, Mufic, \&c.

90 Albertus Magnus-born in Swabia, about I I98-the moft learned man of his age. 


\section{$44 A D V A N C E M E N T$ OF LEARNING.}

being fraught with much fabulous matter, a great part not only untried, but notoriounly untrue, to the great derogation of the credit of natural philofophy with the grave and fober kind of wits : wherein the wifdom and integrity of Ariftotle is worthy to be obferved; that, having made fo diligent and exquifite a hiftory of living creatures, hath mingled it fparingly with any vain or feigned matter: and yet on the other fake, ${ }^{91}$ hath caft all prodigious narrations, which he thought worthy the recording, into one book:92 excellently difcerning that matter of manifert truth (fuch whereupon obfervation and rule were to be built), was not to be mingled or weakened with matter of doubtful credit; and yet again, that raricies and reports that feem incredible are not to be fuppreffed or denied to the memory of men.

And as for the facility of credit which is yielded to arts and opinions, it is likewife of two kinds; either when too much belief is attributed to the arts themfelves, or to certain authors in any art. The fiences themfelves, which have had better intelligence and confederacy with the imagination of man than with his reafon, are three in number; aftrology, natural magic, and alchemy: of which fciences, neverthelefs, the ends or pretences are noble. For aftrology pretendeth to difcover that correfpondence or concatenation which is between the fuperior globe and the inferior: natural magic

91 So in all the early editions; fide has been fuggefted.

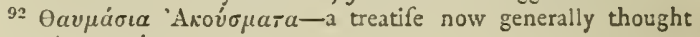
not to be genuine. 
pretendeth to call and reduce natural philofophy from variety of fpeculations to the magnitude of works: and alchemy pretendeth to make feparation of all the unlike parts of bodies which in mixtures of nature are incorporate. But the derivations and profecutions to thefe ends, both in the theories and in the practices, are full of error and vanity; which the great profeffors themfelves have fought to veil over and conceal by enigmatical writings, and referring themfelves to auricular traditions and fuch other devices, to fave the credit of impoftures: and yet furely to alchemy this right is due, that it may be compared to the hufbandman whereof Æfop makes the fable; that, when he died, told his fons that he had left unto them gold buried under ground in his vineyard; and they digged over all the ground, and gold they found none; but by reafon of their ftirring and digging the mould about the roots of their vines, they had a great vintage the year following: fo affuredly the fearch and ftir to make gold hath brought to light a great number of good and fruitful inventions and experiments, as well for the difclofing of nature as for the ufe of man's life.

And as for the overmuch credit that hath been given unto authors in fciences, in making them dictators, that their words fhould ftand, and not counfellors $9^{3}$ to give advice; the damage is infinite that fciences have received thereby, as the principal

93 Ed. 1629 and 1633 have confuls. De Augm. "Dictatoria quadam poteftate munivit ut edicant, non fenatoria ut confulant." Ellis fuggefts that Dacon wrote counfell rs. It clearly thould be counfellors. 
caufe that hath kept them low at a fay without growth or advancement. For hence it hath come, that in arts mechanical the firit devifer comes horteft, and time addeth and perfecteth; but in fciences the firft author goeth farthert, and time leefeth and corrupteth. So we fee, artillery, failing, printing, and the like, were groflly managed at the firft, and by time accommodated and refined: but contrariwife, the philofophies and fiences of Ariftotle, Plato, Democritus, Hippocrates, Euclides, Archimedes, of molt vigour at the firft and by time degenerate and imbafed; whereof the reafon is no other, but that in the former many wits and induftries have contributed in one; and in the latter many wits and induftries have been fpent about the wit of fome one, whom many times they have rather depraved than illuftrated. For as water will not afcend higher than the level of the firft fpringhead from whence it defcendeth, fo knowledge derived from Ariftotle, and exempted from liberty of examination, will not rife again higher than the knowledge of Ariftotle. And therefore although the pofition be good, Oportet difcentem credere, ${ }^{94}$ yet it muft be coupled with this, Oportet edoctum judicare; for difciples do owe unto mafters only a temporary belief and a fufpenfion of their own judgment until they be fully inftructed, and not an abfolute refignation or perpetual captivity : and therefore, to conclude this point, I will fay no more, but fo let great authors have their due, as time, which is the author of authors, be not de-

$$
94 \text { Arift. Sopb. El. } 2 .
$$


prived of his due, which is, further and further to difcover truth.

4. Thus have I gone over thefe three difeafes of Leffer erlearning; befides the which there are fome other ${ }_{\text {Learned }}$ rather peccant humours than formed difeafes: which Men. neverthelefs are not fo fecret and intrinfic but that they fall under a popular obfervation and traducement, and therefore are not to be paffed over.

(a) The firft of thefe is the extreme affecting of Affectation two extremities; the one antiquity, the other no- of extremes. velty; wherein it feemeth the children of time do take after the nature and malice of the father. For as he devoureth his children, fo one of them feeketh to devour and fupprefs the other; while antiquity envieth there fhould be new additions, and novelty cannot be content to add but it muft deface. Surely the advice of the prophet is the true direction in this matter, State fuper vias antiquas, et videte quanam fit via recta et bona et ambulate in ea. ${ }^{95}$ Antiquity deferveth that reverence, that men fhould make a fand thereupon and difcover what is the beft way; but when the difcovery is well taken, then to make progreffion. And to fpeak truly, Antiquitas faculi jurentus mundi. ${ }^{6}$ Thefe times are the ancient times, when the world is ancient, and not thofe which we account ancient ordine retrogrado, by a computation backward from ourfelves.

(b) Another error induced by the former is a Diftruft of diftruft that anything hould be now to be found novelty. out, which the world thould have miffed and paffed

${ }^{95}$ Jerem. vi. 16.

${ }^{96}$ See Nov. Org. i. 84. 


\section{ADVANCEMENT OF LEARNING.}

over fo long time; as if the fame objection were to be made to time, that Lucian maketh to Jupiter and other the heathen gods; of which he wondereth that they begot fo many children in old time, and begot none in his time; and anketh whether they were become feptuagenary, or whether the law Papia, made againft old men's marriages, had reftrained them. So it feemeth men doubt left time is become paft children and generation; wherein, contrariwife, we fee commonly the levity and inconftancy of men's judgments, which till a matter be done, wonder that it can be done; and as foon as it is done, wonder again that it was no fooner done: as we fee in the expedition of Alexander into Afia, which at firft was prejudged as a vaft and impoffible enterprife; and yet afterwards it pleafeth Livy to make no more of it than this: Nil aliud quàm bene aujus vana contemnere ${ }^{97}$ and the fame happened to Columbus in the weftern navigation. But in intellectual matters it is much more common; as may be feen in moft of the propofitions of Euclid; which till they be demonftrate, they feem ftrange to our affent; but being demonftrate, our mind accepteth of them by a kind of relation (as the lawyers fpeak), as if we had known them before.

Belief in 3. Another error, that hath alfo fome affinity the wifdom with the former, is a conceit that of former opin-
of the paft. ions or fects, after variety and examination, the beft hath ftill prevailed and fuppreffed the reft; fo as, if a man fhould begin the labour of a new fearch, 
he were but like to light upon fomewhat formerly rejected, and by rejection brought into oblivion: as if the multitude, or the wifelt for the multitude's fake, were not ready to give paffage rather to that which is popular and fuperficial than to that which is fubftantial and profound; for the truth is that time feemeth to be of the nature of a river or ftream, which carrieth down to us that which is light and blown up, and finketh and drowneth that which is weighty and folid.

4. Another error, of a diverfe nature from all Method. the former, is the over early and peremptory reduction of knowledge into arts and methods; from which time commonly fciences receive fmall or no augmentation. But as young men, when they knit and thape perfectly, do feldom grow to a further ftature; fo knowledge, while it is in aphorifms and obfervations, it is in growth : but when it once is comprehended in exact methods, it may perchance be further polifhed and illuftrate ${ }^{98}$ and accommodated for ufe and practice; but it increafeth no more in bulk and fubftance.

5. Another error, which doth fucceed that which Love of we laft mentioned, is that after the diftribution of particulars. particular arts and fciences, men have abandoned univerfality, or pbilofophia prima; which cannot but ceafe and ftop all progreffion. For no perfect difcovery can be made upon a flat or a level: neither is it poffible to difcover the more remote and deeper parts of any fcience, if you ftand but upon

93 So in Ed. 1605 . 


\section{ADVANCEMENT OF LEARNING.}

the level of the fame fcience, and afcend not to a higher fience.

Reverence. 6. Another error hath proceeded from too great a reverence, and a kind of adoration of the mind and underftanding of man; by means whereof men have withdrawn themfelves too much from the contemplation of nature, and the obfervations of experience, and have tumbled up and down in their own reafon and conceits. Upon thefe intellectualifts, which are notwithftanding commonly taken for the moft fublime and divine philofophers, Heraclitus gave a juft cenfure, faying, Men fought truth in their swn little worlds, and nst in the great and common world; $; 9$ for they difdain to fpell, and fo by degrees to read in the volume of God's works: and contrariwife by continual meditation and agitation of wit do urge and as it were invocate their own fpirits to divine and give oracles unto them, whereby they are defervedly deluded.

Intercix- $\quad 7$. Another error that hath fome connection ture o:

î̀rourite is dies, \&s. their meditations, opinions, and doctrines, with fome conceits which they have moft admired, or fome fciences which they have moft applied; and given all things elfe a tincture according to them, utterly untrue and unproper. So hath Plato intermingled his philofophy with theology, and Ariftotle with logic; and the fecond fchool of Plato, Proclus and the reft, with the mathematics. ${ }^{1}$ For thefe were the arts which had a kind of primoge-

on Sex: Empir. adv. ML:b. rii. Ij3.

1 See Nov. Orz. i. 63 . 
niture with them feverally. So have the alchymifts made a philofophy out of a few experiments of the furnace; and Gilbertus, ${ }^{2}$ our countryman, hath made a philofophy out of the obfervations of a lodeftone. So Cicero, when reciting the feveral opinions of the nature of the foul he found a mufician that held the foul was but a harmony, faith pleafantly, Hic ab arte fua non recefit, Ecc. ${ }^{3}$ But of thefe conceits Ariftotle fpeaketh ferioufly and wifely, when he faith, 2ui respiciunt ad pauca de facili pronunciant. *

8. Another error is an impatience of doubt, Impatience and hafte to affertion without due and mature of doubt. fufpenfion of judgment. For the two ways of contemplation are not unlike the two ways of action commonly fpoken of by the ancients; the one plain and fmooth in the beginning, and in the end impaffable; the other rough and troublefome in the entrance, but after a while fair and even. So it is in contemplation; if a man will begin with certainties, he fhall end in doubts; but if he will be content to begin with doubts, he fhall end in certainties.

9. Another error is in the manner of the tradi- Manner of tion and delivery of knowledge, which is for the traditicn of moft part magiftral and peremptory, and not ingenuous and faithful; in a fort as may be foonelt believed, and not eafilieft examined. It is true, that in compendious treatifes for practice that form

2 See Nov. Org. i. 64 .

3 Tufcul. D:jp. i, x. zo. He is fpeaking of Ariftoxenus. Plato, in the Ploads, pp. 56 and 61 , introduces the fame analogy:

4 De Gener. el Corrupt. i. 2. 


\section{ADVANCEMENT OF LEARNING.}

is not to be difallowed: but in the true handling of knowledge, men ought not to fall either on the one fide into the vein of Velleius the Epicurean : Nil tam metuens, quàm ne dubitare aliqua de re videretur $;^{5}$ nor on the other fide into Socrates his ironical doubting of all things ${ }^{6}$ but to propound things fincerely with more or lefs affeveration, as they ftand in a man's own judgment proved more or lefs.

Low ends. 10. Other errors there are in the fcope that men propound to themfelves, whereunto they bend their endeavours; for whereas the more conftant and devote ${ }^{\tau}$ kind of profeffors of any fcience ought to propound to themfelves to make fome additions to their fcience, they convert their labours to afpire to certain fecond prizes: as to be a profound interpreter or commenter, to be a hharp champion or defender, to be a methodical compounder or abridger; and fo the patrimony of knowledge cometh to be fometimes improved, but feldom augmented.

Mirtale in the fartheft end of knowledge.

I 1. But the greateft error of all the reft is the miftaking or mifplacing of the laft or fartheft end of knowledge : for men have entered into a defire of learning and knowledge, fometimes upon a natural curiofity and inquifitive appetite; fometimes to entertain their minds with variety and delight; fometimes for ornament and reputation ; and

3 Cic. De Nat. Deor. I. viii. 18.

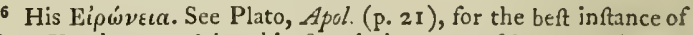
this. He there explains his fuperiority to confint in the knowledge of his own ignorance.

7 So Ed. 1605 . 
fometimes to enable them to victory of wit and contradiction; and moft times for lucre and profeffion; and feldom fincerely to give a true account of their gift of reafon, to the benefit and ufe of men: as if there were fought in knowledge a couch whereupon to reft a fearching and reftlefs fpirit; or a tarraffe, for a wandering and variable mind to walk up and down with a fair profpect; or a tower of ftate, for a proud mind to raife itfelf upon; or a fort or commanding ground, for Atrife and contention; or a thop, for profit or fale; and not a rich ftorehoufe, for the glory of the Creator and the relief of man's eftate. But this is that which will indeed dignify and exalt knowledge, if contemplation and action may be more nearly and Atraitly conjoined and united together than they have been; a conjunction like unto that of the two higheft planets, Saturn, the planet of reft and contemplation, and Jupiter, the planet of civil fociety and action: howbeit, I do not mean, when I fpeak of ufe and action, that end before-mentioned of the applying of knowledge to lucre and profeffion; for I am not ignorant how much that diverteth and interrupteth the profecution and advancement of knowledge, like unto the golden ball thrown before Atalanta, which while the goeth afide and ftoopeth to take up, the race is hindered;

Declinat curfus, aurumque volubile tollit. ${ }^{8}$

I2. Neither is my meaning, as was fpoken of 8 Ovid, Metam. x. 667 . 
Socrates, to call philofophy down from heaven to converfe upon the earth $; 9$ that is, to leave natural philorophy afide, and to apply knowledge only to manners and policy. But as both heaven and earth do confpire and contribute to the ufe and benefit of man; fo the end ought to be, from both philofophies to feparate and reject vain fpeculations, and whatfoever is empty and void, and to preferve and augment whatfoever is folid and fruitful : that knowledge may not be, as a curtefan, for pleafure and vanity only, or as a bond-woman, to acquire and gain to her mafter's ufe; but as a fpoufe, for generation, fruit, and comfort.

Thus have I defcribed and opened, as by a kind of diffection, thofe peccant humours, (the principal of them, ) which hath ${ }^{10}$ not only given impediment to the proficience of learning, but have given alfo occafion to the traducement thereof: wherein if I have been too plain, it muft be remembered, fidelia vulnera amantis, fed dolofa ofcula malignantis.11 This, I think, I have gained, that I ought to be the better believed in that which I fhall fay pertaining to commendation; becaufe I have proceeded fo freely in that which concerneth cenfure. And yet I have no purpofe to enter into a laudative of learning, or to make a hymn to the Mufes; (though I am of opinion that it is long fince their rites were duly celebrated:) but my intent is, without varnifh or amplification juftly to weigh

9 Cic. Tufc. Diffp. v. 4, ro.

10 In all Editions batb. For in Bacon's time the verb fingular was very commonly ufed with more nominatives than one, and even with plural nouns, as here.

11 Prov. xxvii. 6. 


\section{$B O O K I$.}

the dignity of knowledge in the balance with other things, and to take the true value thereof by teftimonies and arguments divine and human.

II. i. Firft therefore let us feek the dignity of Divine Knowledge in the archetype or firft platform, Proofs of which is in the attributes and acts of God, as far of Knowas they are revealed to man and may be obferved ledge. with fobriety; wherein we may not feek it by the I. God's name of Learning; for all Learning is Knowledge own wilacquired, and all knowledge in God is original: and therefore we muft look for it by another name, that of Wifdom or Sapience, as the Scriptures call it.

It is fo then, that in the work of the creation we fee a double emanation of Virtue from God; the one referring more properly to Power, the other to Widom; the one expreffed in making the fubfiftence of the matter, and the other in difpofing the beauty of the form. This being fuppofed, it is to be obferved that for anything which appeareth in the hiftory of the creation, the confufed mafs and matter of Heaven and Earth was made in a moment; and the order and difpofition of that chaos or mafs was the work of fix days; fuch a note of difference it pleafed God to put upon the works of Power, and the works of IVifdom; wherewith concurreth, that in the former it is not fet down that God faid, Let there be beaven and earth, as it is fet down of the works following; but actually, that God made Heaven and Earth: the one carrying the ftyle of a Manufacture, and the other of a Law, Decree, or Counfel. 


\section{ADVANCEMENT OF LEARNING.}

2. The wif- To proceed to that which is next in order from Angels.

God, to Spirits ; 12 we find, as far as credit is to be given to the celeftial hierarchy of that fuppofed Dionyfius the fenator of Athens, the firft place or degree is given to the angels of Love, which are termed Seraphim; the fecond to the angels of Light, which are termed Cherubim; and the third, and fo following places, to Thrones, Principalities, and the reft, which are all angels of power and miniftry; fo as the angels of Knowledge and Illumination are placed before the angels of Office and Domination., ${ }^{13}$

3. Creation To defcend from Spirits and Intellectual Forms of light.

to Senfible and Material Forms; we read the firft Form that was created was Light, ${ }^{14}$ which hath a relation and correfpondence in nature and corporal things to Knowledge in Spirits and incorporal things.

4. God's So in the diftribution of days we fee the day contempla- wherein God did reft and contemplate His own
tion of Creation. works, was bleffed above all the days wherein $\mathrm{He}$ did effect, and accomplifh them. ${ }^{15}$

5. Man's After the creation was finifhed, it is fet down endin Eden, unto us that man was placed in the garden to work
knowledge. therein ; which work, fo appointed to him, could be no other than work of Contemplation; that is, when the end of work is but for exercife and experiment, not for neceffity; for there being then no reluctation of the creature, nor fweat of the brow, man's employment muft of confequence

12 Cf. Hooker, E. P. I. iv. I, 2.

13 Dionys. De Coelefti Hierarcb. cap. 7, 8, 9. This work is, as Bacon hints, fpurious, though no other auther is affigned.

14 Gen. i. 3 .

'. Gen. ii. 3 . 
have been matter of delight in the experiment, and not matter of labour for the ufe. Again, the firit acts which man performed in Paradife confifted of the two fummary parts of knowledge; the view of creatures, and the impofition of names. ${ }^{16}$ As for the knowledge which induced the fall, it was, as was touched before, not the natural knowledge of creatures, but the moral knowledge of good and evil; wherein the fuppofition was, that God's commandments or prohibitions were not the originals of good and evil, but that they had other beginnings, which man afpired to know; to the end to make a total defection from God and to depend wholly upon himfelf.

To pafs on: in the firft event or occurrence 6. Abel's after the fall of man, we fee, (as the Scriptures have infinite myfteries, not violating at all the templation have infinite mylteries, not violating at all the blefied. truth of the ftory or letter,) an image of the two eftates, the contemplative ftate and the active ftate, figured in the two perfons of Abel and Cain, and in the two fimpleft and moft primitive trades of life; that of the thepherd, (who, by reafon of his leifure, reft in a place, and living in view of heaven, is a lively image of a contemplative life,) and that of the hurbandman: ${ }^{17}$ where we fee again the favour and election of God went to the fhepherd, and not to the tiller of the ground.

So in the age before the flood, the holy records within thofe few memorials which are there entered and regiftered have vouchfafed to mention and honour the name of the inventors and authors 7. God honours inventors before the flood. of mufic and works in metal. ${ }^{18}$ In the age after 16 Gen. ii. 19. 17 iv. $2 \quad 18$ iv. $21,22$. 
the flood, the firft great judgment of God upon the ambition of man was the confufion of tongues $;^{19}$ whereby the open trade and intercourfe of learning and knowledge was chiefly imbarred.

8. The To defcend to Mofes the lawgiver, and God's learning of firft pen: he is adorned by the Scriptures with
Mofes. this addition and commendation, That he was feen in all the learning of the Egyptians; ${ }^{20}$ which nation, we know, was one of the moft ancient fchools of the world: for fo Plato brings in the Egyptian prieft faying unto Solon: You Grecians are ever children; you have no knowledge of antiquity, nor antiquity of knowledge. ${ }^{21}$ Take a view of the ceremonial law of Mofes; you thall find, befides the prefiguration of Chrift, the badge or difference of the people of God, the exercife and impreflion of obedience, and other divine ufes and fruits thereof, that fome of the moft learned Rabbins have travailed profitably and profoundly to obferve, fome of them a natural, fome of them a moral fenfe, or reduction of many of the ceremonies and ordinances. As in the law of the leprofy, where it is faid, If the whitenefs have overfpread the flefh, the patient may pass abroad for clean; but if there be any whole flefh remaining, be is to be Sut up for unclean ;22 one of them noteth a principle of nature, that putrefaction is more contagious before maturity than after: and another noteth a pofition of moral philofophy, that men abandoned to vice do not fo much corrupt manners,
19 Gen. xi.
20 Act. Ap. vii. 22.
${ }^{21}$ Plat. Tim. iii. 22.
${ }^{22}$ Levit. xiii. 12-I4. 
as thofe that are half good and half evil. So in this and very many other places in that law, there is to be found, befides the theological fenfe, much afperfion of philofophy.

So likewife in that excellent book of Job, if it be 9. Job's

revolved with diligence, it will be found pregnant learning. and fwelling with natural philofophy; as, for example, cofmography, and the roundnefs of the world, 2ui extendit aquilonem fuper vacuum, et appendit terram fuper nibilum; ${ }^{23}$ wherein the penfilenefs of the earth, the pole of the north, and the finitenefs or convexity of heaven are manifeftly touched. So again, matter of aftronomy; Spiritus ejus ornavit colos, et obftetricante manu ejus eductus eft coluber tortuofus. ${ }^{24}$ And in another place; Nunquid conjungere valebis micantes fellas Pleiadas, aut gyrum Arcturi poteris difipare? ${ }^{25}$ Where the fixing of the ftars, ever ftanding at equal diftance, is with great elegancy noted. And in another place, शui facit Arcturum, et Oriona, et Hyadas, et interiora Aufri; $; 6$ where again he takes knowledge of the depreffion of the foutherr pole, calling it the fecrets of the fouth, becaufe the fouthern ftars were in that climate unfeen. Matter of generation; Annon ficut lac mulfifti me, et ficut cafeum coagulafii me? \&c. ${ }^{27}$ Matter of minerals; Habet argentum venarum fuarum principia: et auro locus eft in quo conflatur, ferrum de terra tollitur, et lapis folutus calore in as vertitur $:{ }^{28}$ and fo forwards in that chapter.

$\begin{array}{lll}23 \\ \text { Job xxvi. } 7 . & 21 \text { xxvi. 1 3. } & 25 \text { xxxviii. } 31 . \\ 26 \text { ix. } 9 . & 27 \text { x. 10. } & 28 \text { xxviii. I. }\end{array}$


10. Solomon.
11. Our Lord fubdued ignorance.

So likewife in the perfon of Salomon the King, we fee the gift or endowment of wifdom and learning, both in Salomon's petition and in God's affent thereunto, preferred before all other terrene and temporal felicity. ${ }^{29}$ By virtue of which grant or donative of God Salomon became enabled not only to write thofe excellent Parables or Aphorifms concerning divine and moral philofophy; but alfo to compile a Natural Hiftory of all verdure, from the cedar upon the mountain to the mofs upon the wall, (which is but a rudiment between putrefaction and a herb, $)^{30}$ and alfo of all things that breathe or move. ${ }^{31}$ Nay, the fame Salomon the King, although he excelled in the glory of treafure and magnificent buildings, of Thipping and navigation, of fervice and attendance, of fame and renown, and the like, yet he maketh no claim to any of thofe glories, but only to the glory of inquifition of truth; for fo he faith exprefly, The glory of God is to conceal a thing, but the glory of the king is to find it out; ${ }^{32}$ as if, according to the innocent play of children, the Divine Majefty took delight to hide His works, to the end to have them found out; and as if kings could not obtain a greater honour than to be God's playfellows in that game; confidering the great commandment of wits and means, whereby nothing needeth to be hidden from them.

Neither did the difpenfation of God vary in the times after our Saviour came into the world; for 29 I Kings iii. 5, 999 . 30 Nov. Org. ii. 30. 31 I Kings iv. 33. 32 Prov. xxv, 2. 
our Saviour Himfelf did firft thow His power to fubdue ignorance, by $\mathrm{His}$ conference with the priefts and doctors of the law, ${ }^{33}$ before He fhowed His power to fubdue nature by $H$ is miracles. And the coming of the Holy Spirit was chiefly figured and expreffed in the fimilitude and gift of tongues, ${ }^{3+4}$ which are but vebicula fcientice.

So in the election of thofe inftruments, which it pleafed God to ufe for the plantation of the Faith, notwithftanding that at the firft $\mathrm{He}$ did employ perfons altogether unlearned, otherwife than by infpiration, more evidently to declare His immediate working, and to abafe all human wifdom or knowledge; yet, neverthelefs, that counfel of His was no fooner performed, but in the next viciffitude and fucceffion $\mathrm{He}$ did fend His Divine Truth into the world waited on with other learnings, as with fervants or handmaids; for fo we fee St. Paul, who was the only learned amongft the Apoftles, had his pen moft ufed in the Scriptures of the New Teftament.

So again, we find that many of the ancient 13. Learned Birhops and Fathers of the Church were excellently read and fudied in all the learning of the heathen; infomuch that the edict of the Emperor Julianus, ${ }^{35}$ whereby it was interdicted unto Chriftians to be admitted into fchools, lectures, or exercifes of learning, was efteemed and accounted a more pernicious engine and machination againft

12. The Apoftles not all unlearned. St. Paul.

Bilhops, \&ec. 
the Chriftian Faith, than were all the fanguinary profecutions of his predeceffors; neither could the emulation and jealoufy of Gregory the firft of that name, bilhop of Rome, ${ }^{36}$ ever obtain the opinion of piety or devotion; but contrariwife received the cenfure of humour, malignity, and pufillanimity, even amongft holy men; in that he defigned to obliterate and extinguifh the memory of heathen antiquity and authors. But contrariwife, it was the Chriftian Church, which, amidft the inundations of the Scythians on the one fide from the north-weft, and the Saracens from the eaft, did preferve in the facred lap and bofom thereof the precious relics even of heathen learning, which otherwife had been extinguinhed as if no fuch thing had ever been.

14. Revival And we fee before our eyes, that in the age of of learning ourfelves and our fathers, when it pleafed God to formation. call the Church of Rome to account for their degenerate manners and ceremonies, and fundry doctrines obnoxious and framed to uphold the fame abufes; at one and the fame time it was ordained by the Divine Providence that there fhould attend withal a renovation and new fpring of all other knowledges. And on the other fide we fee the Jefuits, (who partly in themfelves, and partly by the emulation and provocation of their example, have much quickened and ftrengthened the ftate

36 Gibbon, vol. iv. c. 45 . The ftory that St. Gregory deftroyed the Palatine Library is now rejected; but as to his averfion to profane letters there can be no doubt. Milman's Latin Chriftianity, bk. iii. c. 7 . 
of learning, we fee, I fay, what notable fervice and reparation they have done to the Roman fee.

Wherefore, to conclude this part, let it be obferved, that there be two principal duties and fer15. Conclufion. vices, befides ornament and illuftration, which philofophy and human learning do perform to faith and religion. The one, becaufe they are an effectual inducement to the exaltation of the glory of God: for as the Pfalms and other Scriptures do often invite us to confider and magnify the great and wonderful works of God, 37 fo if we hould reft only in the contemplation of the exterior of them, as they firft offer themfelves to our fenfes, we hould do a like injury unto the Majefty of God, as if we hould judge or conftrue of the ftore of fome excellent jeweller, by that only which is fet out toward the ftreet in his thop. The other, becaufe they minifter a fingular help and prefervative againft unbelief and error: for our Saviour faith, You err, not knowing the Scriptures, nor the power of God; ${ }^{38}$ laying before us two books or volumes to ftudy, if we will be fecured from error; firft, the Scriptures, revealing the Will of God; and then the creatures expreffing His Power ; ${ }^{39}$ whereof the latter is a key unto the former: not only opening our underftanding to conceive the true fenfe of the Scriptures, by the general notions of reafon and rules of fpeech; but chiefly opening our belief, in drawing us into a due meditation of the omnipotency of God, which is chiefly figned and engraven upon His works.

37 Ps, xix riv.

38 Matt. xxii. 29.

39 Cf. Now. Org. i. 89. 


\section{ADVANCEMENT OF LEARNING.}

Thus much therefore for divine teftimony and evidence concerning the true dignity and value of Learning.

Human ii. As for human proofs, it is fo large a field, Proofs. as in a difcourfe of this nature and brevity it is fit rather to ufe choice of thofe things which we Ihall produce, than to embrace the variety of Learning in them. Firft, therefore, in the degrees of human higheft honour honour amongft the heathen, it was the higheft to among the obtain to a veneration and adoration as a God. Heathen. This unto the Chriftians is as the forbidden fruit. But we fpeak now feparately of human teftimony: according to which, that which the Grecians call apotbeojis, and the Latins, relatio inter divos, was the fupreme honour which man could attribute unto man : efpecially when it was given; not by a formal decree or act of ftate, as it was ufed among the Roman Emperors, but by an inward affent and belief. Which honour, being fo high, had alfo a degree or middle term; for there were reckoned above human honours, honours ${ }^{40}$ heroical and divine: in the attribution and diftribution of which honours, we fee antiquity made this difference : that whereas founders and uniters of ftates and cities, law-givers, extirpers of tyrants, fathers of the people, and other eminent perfons in civil merit, were honoured but with the titles of worthies or demi-gods; fuch as were Hercules, r. As bear- Thefeus, Minos, Romulus, and the like: on the ing much other fide, fuch as were inventors and authors of
fruit. new arts, endowments, and commodities towards

$$
\text { 40 All the old Editions read bonour. }
$$


man's life, were ever confecrated amongft the gods themfelves; as were Ceres, Bacchus, Mercurius, Apollo, and others: and juftly; for the merit of the former is confined within the circle of an age or a nation; and is like fruitful fhowers, which though they be profitable and good, yet ferve but for that feafon, and for a latitude of ground where they fall; but the other is indeed like the benefits of heaven, which are permanent and univerfal. The former, again, is mixed with ftrife and perturbation; but the latter hath the true character of Divine Prefence, coming ${ }^{41}$ in aura leni, without noife or agitation.

Neither is certainly that other merit of learning, in repreffing the inconveniences which grow from man to man, much inferior to the former, of re2. Asbringing peace and $\mathrm{fe}-$ lieving the neceffities which arife from nature; which merit was lively fet forth by the ancients in that feigned relation of Orpheus' theatre, where all beafts and birds affembled; and, forgetting their feveral appetites, fome of prey, fome of game, fome of quarrel, ftood all fociably together liftening to the airs and accords of the harp; the found whereof no fooner ceafed, or was drowned by fome louder noife, but every beaft returned to its own nature: wherein is aptly defcribed the nature and condition of men, who are full of favage and unreclaimed defires of profit, of luft, of revenge ; which as long as they give ear to precepts, to curity. 
laws, to religion, fweetly touched with eloquence and perfuafion of books, of fermons, of harangues, fo long is fociety and peace maintained; but if thefe inftruments be filent, or that fedition and tumult make them not audible, all things diffolve into anarchy and confufion.

Efpecially under learned princes.

But this appeareth more manifeftly, when kings themfelves, or perfons of authority under them, or other governors in commonwealths and popular eftates, are endued with learning. For although he might be thought partial to his own profeffion, that faid, Then fould people and eftates be bappy, when either kings were philofophers, or philofophers kings $;^{42}$ yet fo much is verified by experience, that under learned princes and governors there have been ever the beft times: for howfoever kings may have their imperfections in their paffions and cuftoms; yet if they be illuminate by learning, they have thofe notions of religion, policy, and morality, which do preferve them, and refrain them from all ruinous and peremptory errors and exceffes; whifpering evermore in their ears, when counfellors and fervants ftand mute and filent. And fenators or counfellors likewife, which be learned, do proceed upon more fafe and fubftantial principles, than counfellors which are only men of experience: the one fort keeping dangers afar off, whereas the other difcover them not till they come near hand, and then truft to the agility of their wit to ward or avoid them. 
Which felicity of times under learned princes, Such as the (to keep ftill the law of brevity, by ufing the moft eminent and felected examples, ) doth beft appear Domitian. in the age which paffed from the death of Domitian the emperor until the reign of Commodus; comprehending a fucceffion of fix princes, all learned, or fingular favourers and advancers of learning, which age for temporal refpects, was the moft happy and flourifhing that ever the Roman empire, (which then was a model of the world,) enjoyed: a matter revealed and prefigured unto Domitian in a dream the night before he was nain; for he thought there was grown behind upon his fhoulders a neck and a head of gold : which came accordingly to pafs in thofe golden times which fucceeded: of which princes we will make fome commemoration; wherein although the matter will be vulgar, and may be thought fitter for a declamation than agreeable to a treatife infolded as this is, yet becaufe it is pertinent to the point in hand,

\section{Neque femper arcum Tendit Apollo, ${ }^{43}$}

and to name them only were too naked and curfory, I will not omit it altogether. The firft was Nerva; the excellent temper of whofe govern(i.) Nerva. ment is by a glance in Cornelius Tacitus touched to the life: Poftquam divus Nerva res olim infociabiles mifcuifet, imperium et libertatem. ${ }^{4+}$ And in token of his learning, the laft act of his fhort

fix Em- 


\section{ADVANCEMENT OF LEARNING.}

reign left to memory, was a miffive to his adopted fon Trajan, proceeding upon fome inward difcontent at the ingratitude of the times, comprehended in a verfe of Homer's :

Telis, Phøebe, tuis lacrymas ulcifcere noftras. ${ }^{45}$

(2.) Trajan. Trajan, who fucceeded, was for his perfon not learned: but if we will hearken to the fpeech of our Saviour, that faith, He that receiveth a prophet in the name of a prophet, Shall bave a prophet's reward $;^{46}$ he deferveth to be placed amongit the moft learned princes : for there was not a greater admirer of learning, or benefactor of learning; a founder of famous libraries, a perpetual advancer of learned men to office, and a familiar converfer with learned profeffors and preceptors, who were noted to have then moft credit in court. On the other fide, how much Trajan's virtue and government was admired and renowned, furely no teftimony of grave and faithful hiftory doth more lively fet forth, than that legend tale of Gregorius Magnus, bilhop of Rome, who was noted for the extreme envy he bore towards all heathen excellency: and yet he is reported, out of the love and eftimation of Trajan's moral virtues, to have made unto God paffionate and fervent prayers for the delivery of his foul out of hell : ${ }^{47}$ and to have obtained it, with a caveat that he hould make no more fuch petitions. In this prince's time alfo, the perfecution

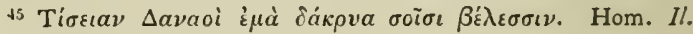
a. 42. Dionis. Epit. (Xiphilini), xii.

${ }^{46}$ Matt. X. 41.

47 See Dante, Purgatorio, $x$. who feems to take it from the Life of Gregory, by John the Deacon. 
againft the Chriftians received intermiffion, upon the certificate of Plinius Secundus, a man of excellent learning, and by Trajan advanced. ${ }^{48}$

Adrian, his fucceffor, was the moft curious man (3.) Adrian. that lived, and the moft univerfal inquirer; infomuch as it was noted for an error in his mind, that he defired to comprehend all things, and not to referve himfelf for the worthieft things: falling into the like humour that was long before noted in Philip of Macedon, who, when he would needs over-rule and put down an excellent mufician in an argument touching mufic, was well anfwered by him again, God forbid, fir, faith he, that your fortune jhould be fo bad, as to know thefe things better than 1.49 It pleafed God likewife to ufe the curiofity of this emperor as an inducement to the peace of His Church in thofe days. For having Chrift in veneration, not as a God or Saviour, but as a wonder or novelty; and having His picture in his gallery, matched with Apollonius, with whom in his vain imagination he thought he had fome conformity; yet it ferved the turn to allay the bitter hatred of thofe times againft the Chriftian name, fo as the Church had peace during his time. And for his government civil, although he did not attain to that of Trajan's in glory of arms, or perfection of juftice, yet in deferving of the weal of the fubject he did exceed him. For Trajan erected many famous monuments and buildings; infomuch as Conftantine the Great in emulation

${ }^{48}$ C. Plin. Epif. x. 97.

49 Plutarch, Apophtb. 179. 


\section{ADVANCEMENT OF LEARNING.}

was wont to call him Parietaria, wall-flower, becaufe his name was upon fo many walls: but his buildings and works were more of glory and triumph than ufe and neceffity. But Adrian fpent his whole reign, which was peaceable, in a perambulation or furvey of the Roman empire; giving order and making aflignation where he went, for re-edifying of cities, towns, and forts decayed; and for cutting of rivers and freams, and for making bridges and paffages, and for policing ${ }^{50}$ of cities and commonalties with new ordinances and conftitutions, and granting new franchifes and incorporations; fo that his whole time was a very reftoration of all the lapfes and decays of former times.

(4.) Antoninus Pius. Antoninus Pius, who fucceeded him, was a prince excellently learned; and had the patient and fubtle wit of a fchoolman; infomuch as in common fpeech, which leaves no virtue untaxed, he was called Cymini Sector, ${ }^{51}$ a carver or divider of cummin, which is one of the leaft feeds; fuch a patience he had and fettled fpirit to enter into the leaft and moft exact differences of caufes; a fruit no doubt of the exceeding tranquillity and ferenity of his mind; which being no ways charged or incumbered, either with fears, remorfes, or fcruples, but having been noted for a man of the pureft goodnels, without all fiction or affectation, that hath reigned or lived, made his mind continually prefent and entire. He likewife approached a degree

so Editions 1605 and 1629 , pollicing, edition 1633 , pollifing.

s1 Unum de iftis puto qui cuminum tecant. Julian, Cas. So

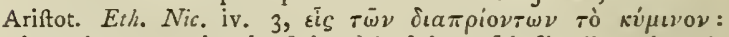
where, however, the phrafe is ufed of the " fkinflint," or niggard. 
nearer unto Chriftianity, and became, as Agrippa faid unto St. Paul, half a Chriftian; ${ }^{52}$ holding their religion and law in good opinion, and not only ceafing perfecution, but giving way to the advancement of Chriftians.

There fucceeded him the firft Divi fratres, the two adoptive brethren, Lucius Commodus Verus, ${ }^{53}$ (fon to Ælius Verus, who delighted much in the fofter kind of learning, and was wont to call the poet Martial his Virgil, ${ }^{54}$ ) and Marcus Aurelius Antoninus; whereof the latter, who obfcured his colleague and furvived him long, was named the philofopher: who, as he excelled all the reft in learning, fo he excelled them likewife in perfection of all royal virtues; infomuch as Julianus the emperor, in his book entitled Cafares, being as a pafquil or fatire to deride all his predeceffors, feigned that they were all invited to a banquet of the gods, and Silenus the jefter fat at the nether end of the table, and beftowed a fcoff on every one as they came in; but when Marcus Philofophus came in, Silenus was gravelled, and out of countenance, not knowing where to carp at him; fave at the laft he gave a glance at his patience towards his wife. And the virtue of this prince, continued with that of his predeceffor, made the name of Antoninus fo facred in the world, that though it were extremely difhonoured in Cominodus, Caracalla, and Heliogabalus, who all bore the name, yet when Alexander Severus refufed

13 Acts xxvi. 28. 33 Better known as L. Aurelius Verus. 34 See his life by Spartianus.

( 5 and 6.) L. Cummodus Verus, and M. Aur. Antoninus. 


\section{ADVANCEMENT OF LEARNING.}

the name, becaufe he was a ftranger to the family, the fenate with one acclamation faid, 2uomodo Auguftus, fic et Antoninus. In fuch renown and veneration was the name of thefe two princes in thofe days, that they would have it as a perpetual addition in all the emperor's ftyle. In this emperor's time alfo the Church for the moft part was in peace; fo as in this fequence of fix princes we do fee the bleffed effects of learning in fovereignty, painted forth in the greateft table of the world.

So under

Queen

Elizabeth.

But for a tablet, or picture of fmaller volume, (not prefuming to fpeak of your majefty that liveth,) in my judgment the moft excellent is that of Queen Elizabeth, your immediate predeceffor in this part of Britain ; a princefs that, if Plutarch were now alive to write lives ${ }^{55}$ by parallels, would trouble him, I think, to find for her a parallel amongtt women. This lady was endued with learning in her fex fingular, and great ${ }^{56}$ even amongft mafculine princes; whether we fpeak of learning, of language, or of fcience, modern or ancient, Divinity or Humanity: and unto the very laft year of her life the was accuftomed to appoint fet hours for reading, fcarcely any young fudent in a univerfity more daily, or more duly. As for her government, I affure myfelf I thall not exceed, if I do affirm that this part of the ifland never had fortyfive years of better times; and yet not through the calmnefs of the feafon, but through the wifdom

55 Ed. 1605 , lynes.

56 Edd. 1629 , $16_{33}$, rare. Ed. 1605 , grace, i.e. "learning in her fex fingular, and grace even amongft mafculine princes." 
of her regiment. For if there be confidered of the one fide, the truth of religion eftablifhed; the conftant peace and fecurity; the good adminiftration of juftice; the temperate ufe of the prerogative, not lackened, nor much ftrained; the flourihing ftate of learning, fortable to fo excellent a patronefs; the convenient eftate of wealth and means, both of Crown and fubject; the habit of obedience, and the moderation of difcontents : and there be confidered on the other fide the differences of religion; the troubles of neighbour countries; the ambition of Spain, and oppofition of Rome; and then, that the was folitary and of herfelf: thefe things, I fay, confidered, as I could not have chofen an inftance fo recent and fo proper, fo I fuppofe I could not have chofen one more remarkable or eminent to the purpofe now in hand, which is concerning the conjunction of learning in the prince with felicity in the people.

Neither hath learning an influence and operation only upon civil merit and moral virtue, and the arts or temperature of peace and peaceable 3. As promoting greatnefs in war. government; but likewife it hath no lefs power and efficacy in enablement towards martial and military virtue and prowefs; as may be notably reprefented in the examples of Alexander the Great, and Cæfar the dictator, mentioned before, but now in fit place to be refumed: of whole virtues and acts in war there needs no note or recital, having been the wonders of time in that kind: but of their affections towards learning, and 


\section{ADVANCEMENT OF LEARNING.}

perfections in learning, it is pertinent to fay fomewhat.

As Alexan- Alexander ${ }^{57}$ was bred and taught under Arifder. totle, the great philofopher, who dedicated divers of his books of philofophy unto him : he was attended with Callifthenes and divers other learned perfons, that followed him in camp, throughout his journeys and conquefts. What price and eftimation he had learning in doth notably appear in thefe three particulars: firft, in the envy he ufed to exprefs that he bore towards Achilles, in this, that he had fo good a trumpet of his praifes as Homer's verfes ; fecondly, in the judgment or folution he gave touching that precious cabinet of Darius, which was found among his jewels; whereof queftion was made what thing was worthy to be put into it; and he gave his opinion for Homer's works: thirdly, in his letter to Ariftotle, after he had fet forth his books of nature, wherein he expoftulated with him for publifhing the fecrets or myfteries of philofophy; and gave him to underftand that himfelf efteemed it more to excel other men in learning and knowledge than in power and empire. And what ufe he had of learning doth appear, or rather thine, in all his fpeeches and anfwers, being full of fcience, and ufe of fcience, and that in all variety.

And herein again it may feem a thing fcholaftical, and fomewhat idle, to recite things that every man knoweth; but yet, fince the argument I handle leadeth me thercunto, I am glad that

s7 Thefe anecdotes of Alexander come from Plutarch, Vit. Alex. 
men thall perceive $I$ am as willing to flatter, if they will fo call it, an Alexander, or a Cæfar, or an Antoninus, that are dead many hundred years fince, as any that now liveth: for it is the difplaying of the glory of learning in fovereignty that I propound to myfelf, and not an humour of declaiming in any man's praifes. Obferve then the fpeech he ufed of Diogenes, and fee if it tend not to the true ftate of one of the greateft queftions of moral philofophy; whether the enjoying of outward things, or the contemning of them, be the greateft happinels: for when he faw Diogenes fo perfectly contented with fo little, he faid to thofe that mocked at his condition, IVere I not Alexander, I would wifh to be Diogenes. But Seneca inverteth it, and faith; Plus erat, quod bic nollet accipere, quàm quod ille poffet dare. ${ }^{58}$ There were more things which Diogenes would have refufed, than there were which Alexander could have given.

Obferve again that fpeech which was ufual with him, That be felt bis mortality chiefly in two things, fleep and luft;59 and fee if it were not a fpeech extracted out of the depth of natural philofophy, and liker to have come out of the mouth of Ariftotle or Democritus, than from Alexander.

See again that fpeech of humanity and poefy ; when upon the bleeding of his wounds, he called unto him one of his flatterers, that was wont to afcribe to him divine honour, and faid, Look, this is very blood; this is not fuch a liquor as Homer

$$
{ }^{38} \text { Sen. De Benef. v. } 4 .
$$$$
\text { so Sen. Ep. Mor. vi. } 7 \text {. }
$$ 
speaketh of, which ran from Venus' band, when it was pierced by Diomedes. ${ }^{60}$

See likewife his readinefs in reprehenfion of logic, in the fpeech he ufed to Caffander, upon a complaint that was made againft his father Antipater: for when Alexander happened to fay, Do you think thefe men would have come from fo far to complain, except they had juft caufe of grief? And Caffander anfwered, $Y_{e a}$, that was the matter, becaufe they thought they fhould not be difproved. Said Alexander laughing: See the fubtilties of Ariftotle, to take a matter botb ways, pro et contra, $\xi^{\circ} c$.

But note again how well he could ufe the fame art, which he reprehended, to ferve his own humour: when bearing a fecret grudge to Callifthenes, becaufe he was againit the new ceremony of his adoration, feafting one night where the fame Callifthenes was at the table, it was moved by fome after fupper, for entertainment fake, that Callifhenes, who was an eloquent man, might fpeak of fome theme or purpofe at his own choice; which Callifhenes did; choofing the praife of the Macedonian nation for his difcourfe, and performing the fame with fo good manner, as the hearers were much ravifhed: whereupon Alexander, nothing pleafed, faid, It was eafy to be eloquent upon fo good a Jubject. But, faith he, Turn your fyle, and let us bear what you can fay againft us: which Callifthenes prefently undertook, and

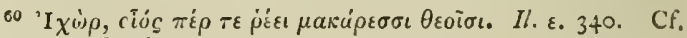
Seneca, ad Lucll. 59. 
did with that fting and life, that Alexander interrupted him, and faid, The goodnefs of the caufe made bim eloquent before, and defpite made bim eloquent then again.

Confider further, for tropes of rhetoric, that excellent ufe of a metaphor or tranflation, wherewith he taxed Antipater, who was an imperious and tyrannous governor: for when one of Antipater's friends commended him to Alexander for his moderation, that he did not degenerate, as his other lieutenants did, into the Perfian pride, in ufe of purple, but kept the ancient habit of Macedon, of black; ${ }^{61}$ True, faith Alexander, but Antipater is all purple within.62 Or that other, when Parmenio came to him in the plain of Arbela, and fhowed him the innumerable multitude of his enemies, efpecially as they appeared by the infinite number of lights, as it had been a new firmament of ftars, and thereupon advifed him to affail them by night: whereupon he anfwered, That be would not fleal the victory.

For matter of policy, weigh that fignificant diftinction, fo much in all ages embraced, that he made between his two friends, Hephæetion and Craterus, when he faid, That the one loved Alexander, and the otber loved the king: defcribing the principal difference of princes' beft fervants, that fome in affection love their perfon, and others in duty love their crown.

Weigh alfo that excellent taxation of an error, ordinary with counfellors of princes, that they

61 The Greek is $\lambda \varepsilon v \kappa o \pi a ́ \rho v \phi o s$.

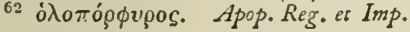


76 ADVANCEMENT OF LEARNING.

Speaketh of, which ran from Venus' band, when it was pierced by Diomedes. 60

See likewife his readinefs in reprehenfion of logic, in the fpeech he ufed to Caffander, upon a complaint that was made againft his father Antipater: for when Alexander happened to fay, Do you think thefe men would bave come from fo far to complain, except they had juft cause of grief? And Caflander anfwered, $r_{e a}$, that was the matter, becaufe they thought they fhould not be difproved. Said Alexander laughing: See the fubtilties of Ariftotle, to take a matter both ways, pro et contra, $\xi^{\circ} c$.

But note again how well he could ufe the fame art, which he reprehended, to ferve his own humour : when bearing a fecret grudge to Callifthenes, becaufe he was againft the new ceremony of his adoration, feafting one night where the fame Callifthenes was at the table, it was moved by fome after fupper, for entertainment rake, that Callifhenes, who was an eloquent man, might fpeak of fome theme or purpofe at his own choice; which Callifthenes did; choofing the praife of the Macedonian nation for his difcourfe, and performing the fame with fo good manner, as the hearers were much ravihed: whereupon Alexander, nothing pleafed, faid, It was eafy to be eloquent upon fo good a fubject. But, faith he, Turn your fyle, and let us bear what you can fay againft us: which Callifthenes prefently undertook, and

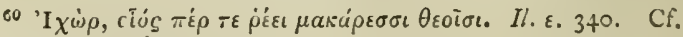
Seneca, ad Lucil. 59 . 


\section{$B O O K I$.}

did with that fting and life, that Alexander interrupted him, and faid, The goodnefs of the caufe made bim eloquent before, and defpite made bim eloquent then again.

Confider further, for tropes of rhetoric, that excellent ufe of a metaphor or tranflation, wherewith he taxed Antipater, who was an imperious and tyrannous governor: for when one of Antipater's friends commended him to Alexander for his moderation, that he did not degenerate, as his other lieutenants did, into the Perfian pride, in ufe of purple, but kept the ancient habit of Macedon, of black; ;1 True, faith Alexander, but Antipater is all purple within. ${ }^{6 \Omega}$ Or that other, when Parmenio came to him in the plain of Arbela, and fhowed him the innumerable multitude of his enemies, efpecially as they appeared by the infinite number of lights, as it had been a new firmament of ftars, and thereupon advifed him to affail them by night: whereupon he anfwered, That be would not fteal the victory.

For matter of policy, weigh that fignificant diftinction, fo much in all ages embraced, that he made between his two friends, Hephæftion and Craterus, when he faid, That the one loved Alexander, and the other loved the king : defcribing the principal difference of princes' beft fervants, that fome in affection love their perfon, and others in duty love their crown.

Weigh alfo that excellent taxation of an error, ordinary with counfellors of princes, that they

${ }^{61}$ The Greek is $\lambda \varepsilon v \kappa o \pi a ́ p v \phi o s$.

62 ò 
he collected, we fee that he efteemed it more honour to make himfelf but a pair of tables to take the wife and pithy words of others, than to have every word of his own to be made an apophthegm or an oracle; as vain princes, by cuftom of flattery, pretend to do. ${ }^{65}$ And yet if I fhould enumerate divers of his fpeeches, as I did thofe of Alexander, they are truly fuch as Solomon noteth, when he faith, Verba fapientum tanquam aculei, et tanquam clavi in altum defixi: $:^{66}$ whereof I will only recite three, not fo delectable for elegancy, but admirable for vigour and efficacy.

As, firft, it is reafon he be thought a mafter of words, that could with one word appeafe a mutiny in his army, which was thus: The Romans, when their generals did fpeak to their army, did ufe the word milites, but when the magiftrates fpake to the people, they did ufe the word Quirites. The foldiers were in tumult, and feditioufly prayed to be cafhiered; not that they fo meant, but by expoftulation thereof to draw Cærar to other conditions; wherein he being refolute not to give way, after fome filence, he began his fpeech, $E g \sigma$, 2uirites, ${ }^{6 \tau}$ which did admit them already cafhiered; wherewith they were fo furprifed, croffed, and confufed, as they would not fuffer him to go on in his fpeech, but relinquifhed their demands, and made it their fuit to be again called by the name of milites.

The fecond fpeech was thus: Cafar did extremely affect the name of king; and fome were

${ }^{\text {as }}$ Cic. Epijt. ad Div. ix. 16.

66 Eccl. xii. II.

${ }^{67}$ Suet. Ful, Coss. c. 70. 
fet on as he paffed by in popular acclamation to falute him king: whereupon, finding the cry weak and poor, he put it off thus, in a kind of jeft, as if they had iniftaken his furname; Non Rex fum, fed Coefar; ${ }^{68}$ a fpeech that if it be fearched the life and fulnels of it can fcarce be exprefled. For, furt, it was a refufal of the name, but yet not ferious: again, it did fignify an infinite confidence and magnanimity, as if he prefumed Cæfar was the greater title; as by his worthinefs it is come to pafs till this day: but chiefly it was a fpeech of great allurement toward his own purpofe; as if the ftate did ftrive with him but for a name, whereof mean families were vefted; for $R e x$ was a furname with the Romans, as well as King is with us. ${ }^{69}$

The laft fpeech which I will mention, was ufed to Metellus, when Cæfar after war declared did poffers himfelf of the city of Rome; at which time entering into the inner treafury to take the money there accumulated, Metellus being tribune forbade him : whereto Cæfar faid, That if be did not defist, be would lay bim dead in the place. And prefently taking himfelf up, he added, Adolefcens, durius eft mibi boc dicere quàm facere. roung man, it is harder for me to Speak than to do it..$^{i 0} \mathrm{~A}$ fpeech compounded of the greateft terror and greateft clemency that could proceed out of the mouth of man. ${ }^{71}$

65 Suet. $\mathcal{F}$ ul. Caes, c. 70.

69 Cf. Hor. Sat. I. vii.

70 Plutarch, Ful. Cas.

i1 To thete might have well been added Cafar's exhortation to the boatman, "Thou carrieft Cafar and his fortunes." 
But to return and conclude with him; it is evident, himfelf knew well his own perfection in learning, and took it upon him; as appeared when, upon occafion that fome fpake what a ftrange refolution it was in Lucius Sylla to refign his dictature; he fcoffing at him to his own advantage anfwered, That Sylla could not fkill of letters, and therefore knew not bow to dictate. ${ }^{2}$

And Xeno- And here it were fit to leave this point, touching phon.

the concurrence of military virtue and learning; (for what example would come with any grace after thofe two of Alexander and Cafar?) were it not in regard of the rarenefs of circumftance that I find in one other particular, as that which did fo fuddenly pafs from extreme fcorn to extreme wonder; and it is of Xenophon the philofopher, who went from Socrates' fchool into A fia, in the expedition of Cyrus the younger, againft $\mathrm{King}$ Artaxerxes. This Xenophon at that time was very young, and never had feen the wars before; neither had any command in the army, but only followed the war as a voluntary, for the love and converfation of Proxenus his friend. ${ }^{73} \mathrm{He}$ was prefent when Phalynus came in meffage from the great king to the Grecians, after that Cyrus was flain in the field, and they a handful of men left to themfelves in the midft of the king's territories, cut off from their country by many navigable rivers, and many hundred miles. The meflage imported, that they fhould deliver up their arms, and fubmit 72 Suet. Ful. Cas, c. 77 .

7 Xen. Anab. ii. ad fin. 
themfelves to the king's mercy. To which meffage before anfwer was made, divers of the army conferred familiarly with Phalynus, and amongft the reft Xenophon happened to fay, IVhy, Pbalynus, we have now but the e two things left, our arms and our virtue; and if we yield up our arms, bow Shall we make ufe of our virtue? Whereto Phalynus fmiling on him, faid, If $I$ be not deceived, young gentleman, you are an Atbenian: and, I believe you fudy philofophy, and it is pretty that you fay: but you are much abufed, if you think your virtue can withftand the king's power. ${ }^{74}$ Here was the fcorn; the wonder followed: which was, that this young fcholar or philofopher, after all the captains were murdered in parley by treafon, conducted thofe ten thoufand foot through the heart of all the king's high countries from Babylon to Græcia in fafety, in defpite of all the king's forces, to the aftonifhment of the world, and the encouragement of the Grecians in time fucceeding to make invafion upon the kings of Perfia: as was after purpofed by Jafon the Theffalian, attempted by Agefilaus the Spartan, and achieved by Alexander the Macedonian, all upon the ground of the act of that young fcholar.

To proceed now from imperial and military 4. Alfo in virtue to moral and private virtue: firft, it is an affured truth, which is contained in the verfes:

Scilicet ingenuas didiciffe fideliter artes,

Emollit mores, nec finit efle feros. ${ }^{75}$

It taketh away the wildnefs and barbarifm and and private effects by raifing the charakte:s of men.

7 Xen. Anab. ii. 1. 12. ${ }^{75}$ Ov. Ep. Pont. ii. ix. 47. 


\section{ADVANCEMENT OF LEARNING.}

fiercenefs of men's minds; but indeed the accent had need be upon fideliter: for a little fuperficial learning doth rather work a contrary effect. It taketh away all levity, temerity, and infolency, by copious fuggeftion of all doubts and difficulties, and acquainting the mind to balance reafons on both fides, and to turn back the firft offers and conceits of the mind, and to accept of nothing but examined and tried. It taketh away vain admiration of anything, which is the root of all weaknefs: for all things are admired either becaufe they are new, or becaufe they are great. For novelty, no man that wadeth in learning or contemplation thoroughly, but will find that printed in his heart Nil novi Juper terram. ${ }^{76}$ Neither can any man marvel at the play of puppets, that goeth behind the curtain, and advifeth well of the motion. And for magnitude, as Alexander the Great, after that he was ufed to great armies, and the great conquefts of the fpacious provinces in Afia, when he received letters out of Greece, of fome fights and fervices there, which were commonly for a paffage or a fort, or fome walled town at the moft, he faid, It feemed to bim that he was advertifed of the Battle of the Frogs and the Mice, that the old tales went of. $i 7$ So certainly, if a man meditate much upon the univerfal frame of nature, the earth with men upon it (the divinenefs of fouls except,) will not feem much other than an

76 Eccl. i. 9.

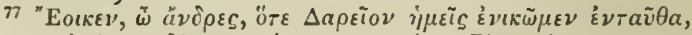

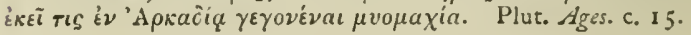




\section{BOOK I.}

ant-hill, whereas fome ants carry corn, and fome carry their young, and fome go empty, and all toand-fro a little heap of duft. It taketh away or mitigateth fear of death, or adverfe fortune; which is one of the greateft impediments of virtue, and imperfections of manners. For if a man's mind be deeply feafoned with the confideration of the mortality and corruptible nature of things, he will eafily concur with Epictetus, who went forth one day and faw a woman weeping for her pitcher of earth that was broken; and went forth the next day and faw a woman weeping for her fon that was dead, and thereupon faid: Heri vidi fragilem frangi, bodie vidi mortalem mori. ${ }^{78}$ And therefore Virgil did excellently and profoundly couple the knowledge of caufes and the conqueft of all fears, together, as concomitantia:

Felix, qui potuit rerum cognofcere caufas, Quique metus omnes, et inexorabile fatum Subjecit pedibus, Atrepitumque Acherontis avari. ${ }^{79}$

It were too long to go over the particular remedies which learning doth minifter to all the difeafes of the mind; fometimes purging the ill-humours, fometimes opening the obftructions, fometimes helping digeftion, fometimes increafing appetite, fometimes healing the wounds and exulcerations thereof, and the like; and, therefore, I will conclude with that which hath rationem totius, which is, that it difporeth the conftitution of the mind not to be fixed or fettled in the defects thereof, but

${ }^{78}$ There is no fuch tale in Epictetus, but fee Simplicii in Epizt. Comment. cap. 33 .

79 Virg. Georg. ii. 490. 


\section{ADVANCEMENT OF LEARNING.}

ftill to be capable and fufceptible of growth and reformation. For the unlearned man knows not what it is to defcend into himfelf, or to call himfelf to account; nor the pleafure of that fuavifima vita, indies fentire fe fieri meliorem.$^{80}$ The good parts he hath he will learn to thow to the full, and ufe them dexteroufly, but not much to increafe them : the faults he hath he will learn how to hide and colour them, but not much to amend them: like an ill mower, that mows on ftill, and never whets his fcythe: whereas with the learned man it fares otherwife, that he doth ever intermix the correction and amendment of his mind with the ufe and employment thereof. Nay, further, in general and in fum, certain it is that Veritas and Bonitas differ but as the feal and the print: for Truth prints Goodnefs; and they be the clouds of error which defcend in the ftorms of paffions and perturbations.

5. In giving From moral virtue let us pals on to matter of dignity to human nacure. power and commandment, and confider whether in right reafon there be any comparable with that wherewith knowledge invefteth and crowneth man's nature. We fee the dignity of the commandment is according to the dignity of the commanded: to have commandment over beafts, as herdmen have, is a thing contemptible; to have commandment over children, as fchoolmafters have, is a matter of fmall honour ; to have commandment over galley-flaves is a difparagement rather than an honour. Neither is the command- 
ment of tyrants much better, over people which have put off the generofity of their minds: and therefore it was ever holden that honours in free monarchies and commonwealths had a fweetnefs more than in tyrannies; becaufe the commandment extendeth more over the wills of men, and not only over their deeds and fervices. And therefore, when Virgil putteth himfelf forth to attribute to Auguitus Cæfar the beft of human honours, he doth it in thefe words:

$$
\text { Per populos dat jura, viamque affectat Olympo. }{ }^{81}
$$

But yet the commandment of knowledge is yet higher than the commandment over the will; for it is a commandment over the reafon, belief, and underftanding of man, which is the higheft part of the mind, and giveth law to the will itfelf. For there is no power on earth which fetteth up a throne or chair of ftate in the fpirits and fouls of men, and in their cogitations, imaginations, opinions, and beliefs, but knowledge and learning. And therefore we fee the deteftable and extreme pleafure that arch-heretics, and falfe prophets, and impoftors are tranfported with, when they once find in themfelves that they have a fuperiority in the faith and confcience of men; fo great as if they have once tafted of it, it is feldom feen that any torture or perfecution can make them relinquifh or abandon it. But as this is that which the author of the Revelation calleth the depth or profoundnefs of Satan : ${ }^{82}$ fo by argument of contra-

$$
\text { - Georg. iv. 561, } 562 \text {. }
$$$$
{ }^{82} \text { Rev. ii. } 24 .
$$ 
6. In advancing worldly interefts.

ries, the juft and lawful fovereignty over men's underftanding, by force ${ }^{83}$ of truth rightly interpreted, is that which approacheth neareft to the fimilitude of the Divine Rule.

As for fortune and advancement, the beneficence of learning is not fo confined to give fortune only to ftates and commonwealths, as it doth not likewife give fortune to particular perfons. For it was well noted long ago, that Homer hath given more men their livings, than either Sylla, or Cæfar, or Auguftus ever did, notwithftanding their great largeffes and donatives, and ditributions of lands to fo many legions. And no doubt it is hard to fay, whether arms or learning have advanced greater numbers. And in cafe of fovereignty we fee, that if arms or defcent have carried away the kingdom, yet learning hath carried the priefthood, which ever hath been in fome competition with empire. ${ }^{84}$

7. In giving Again, for the pleafure and delight of knowpleafure. ledge and learning, it far furpaffeth all other in nature : for, thall the pleafures of the affections fo exceed the fenfes, as much as the obtaining of defire or victory exceedeth a fong or a dinner; and muft not, of confequence, the pleafures of the intellect or underftanding exceed the pleafures of the affections? We fee in all other pleafures there is fatiety, and after they be ufed, their verdure departeth; which fhoweth well they be but deceits

${ }_{63}$ Ed. 1605 reads face.

${ }^{84}$ Cf. Herod, ii. ifil. for the afcendancy of the Priefthood in Egypt. 
of pleafure, and not pleafures: and that it was the novelty which pleafed, and not the quality; and therefore we fee that voluptuous men turn friars, and ambitious princes turn melancholy. But of knowledge there is no fatiety, but fatisfaction and appetite are perpetually interchangeable; and therefore appeareth to be good in itfelf fimply, without fallacy or accident. Neither is that pleafure of fmall efficacy and contentment to the mind of man which the poet Lucretius defcribeth elegantly,

Suave mari magno, turbantibus aquora ventis, $\& c{ }^{85}$

It is a view of delight, faith he, to fand or walk upon the fhore fide, and to See a bip toffed with tempeft upon the fea ; or to be in a fortified tower, and to fee two battles join upon a plain; but it is a pleafure incomparable, for the mind of man to be fettled, landed, and fortified in the certainty of truth; and from thence to defiry and bebold the errors, perturbations, labours, and wanderings up and down of other men.

Laftly, leaving the vulgar arguments, that by 8. Laftly. learning man excelleth man in that wherein man in giving an excelleth beafts; that by learniug man afcendeth to its porto the heavens and their motions, where in body feffors. he cannot come, and the like; let us conclude with the dignity and excellency of knowledge and learning in that whereunto man's nature doth moft alpire, which is, immortality or continuance: for to this tendeth generation, and raifing of houfes and families; to this buildings, foundations, and 
monuments; to this tendeth the defire of memory, fame, and celebration, and in effect the Atrength of all other human defires. We fee then how far the monuments of wit and learning are more durable than the monuments of power or of the hands. For have not the verfes of Homer continued twenty-five hundred years, or more, without the lors of a fyllable or letter; during which time, infinite palaces, temples, caftles, cities, have been decayed and demolifhed? It is not polfible to have the true pictures or ftatues of Cyrus, Alexander, Cæfar; no, nor of the kings or great perfonages of much later years; for the originals cannot laft, and the copies cannot but leefe of the life and truth. But the images of men's wits and knowledges remain in books, exempted from the wrong of time, and capable of perpetual renovation. Neither are they fitly to be called images, becaufe they generate ftill, and caft their fceds in the minds of others, provoking and caufing infinite actions and opinions in fucceeding ages: fo that, if the invention of the fhip was thought fo noble, which carrieth riches and commodities from place to place, and confociateth the moft remote regions in participation of their fruits, how much more are letters to be magnified, which, as fhips, pafs through the vaft feas of time, and make ages fo diftant to participate of the wifdom, illuminations, and inventions, the one of the other? Nay further, we fee fome of the philofophers which were leaft divine, and moft immerfed in the fenfes, 
and denied generally the immortality of the foul, yet came to this point, that whatfoever motions the fpirit of man could act and perform without the organs of the body, they thought might remain after death, which were only thofe of the underftanding, and not of the affection : fo immortal and incorruptible a thing did knowledge feem unto them to be. But we, that know by divine revelation that not only the underftanding but the affections purified, not only the fpirit but the body changed, Thall be advanced to immortality, do difclaim in ${ }^{86}$ thefe rudiments of the fenfes. But it muft be remembered both in this laft point, and fo it may likewife be needful in other places, that in probation of the dignity of knowledge or learning, I did in the beginning feparate divine teftimony from human, which method I have purfued, and fo handled them both apart.

Neverthelefs, I do not pretend, and I know it will be impoffible for me, by any pleading of mine, to reverfe the judgment, either of Æfop's Cock, that preferred the barley-corn before the gem ; or of Midas, that being chofen judge between A pollo, prefdent of the Mufes, and Pan, god of the flocks, judged for plenty: ${ }^{87}$ or of Paris, that judged for beauty and love againft wifdom and power; nor of Agrippina, Occidat matrem, modo imperet, that preferred empire with conditions

86 So all three editions. The Latin has, Nos autcm . . . conculcantes bac rudimenta... novimus. Yerhaps in thould be omitted" do difclaim thefe rudiments of the fenfes."

87 Ov. Met. xi. 1 53, feq. 
92 ADVANCEMENT OF LEARNING.

never fo deteftable; ${ }^{88}$ or of Ulyffes, Qui vetulam pratulit immortalitati, ${ }^{89}$ being a figure of thofe which prefer cuftom and habit before all excellency; or of a number of the like popular judgments. For thefe things continue as they have been: but fo will that alfo continue whereupon learning hath ever relied, and which faileth not: Fufificata eft fapientia a filiis fuis. ${ }^{90}$

88 Tacit. Annal. xiv. 9.

89 Cf. Cic. de Orat.i. 44, where it is Itbaca, not his old wife, that Ulyffes is faid to prefer to immortality.

so Matt. xi. I9.

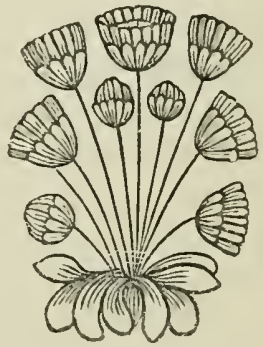




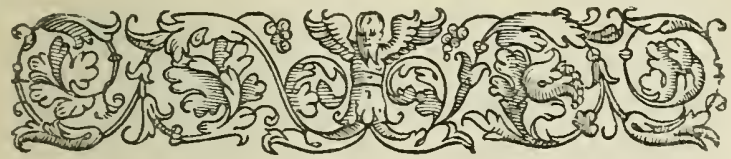

THE SECOND BOOK OF FRANCIS BACON :

\section{Of the Proficience and}

\section{Advancement of Learning}

Divine and Human.

\section{To the King.}

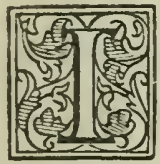

$T$ might feem to have more conve- De Aug. ii. nience, though it come often other- praf. wife to pafs, excellent King, that vancement thofe, which are fruitful in their generations, and have in themfelves the forefight of to the care immortality in their defcendants, thould likewife of Kings be more careful of the good eftate of future times, unto which they know they muft tranfmit and commend over their deareft pledges. Queen Elizabeth was a fojourner in the world in refpect of her unmarried life, and was a bleffing to her own times; and yet fo as the impreffion of her good government, befides her happy memory, is not without fome effect which doth furvive her. But to your Majesty, whom God hath already bleffed with fo much royal iffue, worthy to continue and and others. 


\section{$94 A D V A N C E M E N T$ OF LEARNING.}

reprefent you for ever, and whofe youthful and fruitful bed doth yet promife many of the like renovations; it is proper and agreeable to be converfant not only in the tranfitory parts of good government, but in thofe acts alfo which are in their nature permanent and perpetual: amongit the which, if affection do not tranfport me, there is not any more worthy than the further endowment of the world with found and fruitful knowledge. For why thould a few received authors ftand up like Hercules' columns, ${ }^{1}$ beyond which there fhould be no failing or difcovering, fince we have fo bright and benign a ftar as your Majefty to conduct and profper us? To return therefore where we left, it remaineth to confider of what kind thofe acts are which have been undertaken and performed by kings and others for the increafe and advancement of learning: wherein I purpore to fpeak actively without digreffing or dilating.

Three chief Let this ground therefore be laid, that all works means of help : (I.) Rewards ; (2.) Guidance ; (3.) Combination. are overcome by amplitude of reward, by foundnefs of direction, and by the conjunction of labours. The firf multiplieth endeavour, the fecond preventeth error, and the third fupplieth the frailty of man: but the principal of thefe is direction: for Claudus in via antevertit curforem extra viam; and Salomon excellently fetteth it down, If the iron be not Sharp, it requireth more frength; but wifdom is that which prevaileth ; fignifying that

1 A favourite thought of Bacon's, and exprefied afterwards on the engraved title-page of the firft edition of the Novum Organum, A.D. 1620 .

Eccl. x. 10. 
the invention or election of the mean is more effectual than any inforcement or accumulation of endeavours. This I am induced to fpeak, for that (not derogating from the noble intention of any that have been defervers towards the ftate of learning) I do obferve, neverthelefs, that their works and acts are rather matters of magnificence and memory, than of progreffion and proficience; and tend rather to augment the mass of learning in the multitude of learned men, than to rectify or raife the fciences themfelves.

The works or acts of merit towards learning Three obare converfant about three objects : the places of jects to be learning, the books of learning, and the perfons of (I.) Places the learned. For as water, whether it be the dew of learning; of heaven, or the fprings of the earth, doth fcatter (2.) Books; of heaven, or the fprings of the earth, doth fcatter (3.) Learned and leefe itfelf in the ground, except it be collected perfons. into fome receptacle, where it may by union comfort and fuftain itfelf, (and for that caufe the induftry of man hath made and framed fpring-heads, conduits, cifterns, and pools, which men have accuftomed likewife to beautify and adorn with accomplifhments of magnificence and ftate, as well as of ufe and neceffity) fo this excellent liquor of knowledge, whether it defcend from divine infpiration, or fpring from human fenfe, would foon perifh and vanifh to oblivion, if it were not preferved in books, traditions, conferences, and places appointed, as univerfities, colleges, and fchools, for the receipt and comforting of the fame. 


\section{ADVANCEMENT OF LEARNING.}

(1.) Places of learning, how helped. endowments with revenues, endowments with franchifes and privileges, inftitutions and ordinances for government; all tending to quietnefs and privatenefs of life, and difcharge of cares and troubles; much like the ftations which Virgil prefcribeth for the hiving of bees :

Principio fedes apibus ftatioque petenda, Quo neque fit ventis aditus, \&c. ${ }^{3}$

(2.) Books, The works touching books are two: firft, librahow beft cared for. ries, which are as the fhrines where all the relics of the ancient faints, full of true virtue, and that without delufion or impofture, are preferved and repofed : fecondly, new editions of authors, with more correct impreffions, more faithful tranflations, more profitable gloffes, more diligent annotations, and the like.

(3.) The learned, how heiped.

The works pertaining to the perfons of learned men, befides the advancement and countenancing of them in general, are two: the reward and defignation of readers in fciences already extant and invented; and the reward and defignation of writers and inquirers concerning any parts of learning not fufficiently laboured and profecuted.

Thefe are fummarily the works and acts, wherein the merits of many excellent princes and other worthy perfonages have been converfant. As for any particular commemorations, I call to mind what Cicero faid, when he gave general thanks; Difficile non aliquem, ingratum quenquam

3 Virg. Georg. iv. 8. 


\section{BOOK II.}

preterire. ${ }^{4}$ Let us rather, according to the Scriptures, ${ }^{5}$ look unto that part of the race which is before us than look back to that which is already attained.

Firft, therefore, amongft fo many great foundations of colleges in Europe, I find it ftrange that they are all dedicated to profeffions, and none left free to arts and fciences at large. For if men judge that learning thould be referred to action, Seats of learning faulty, (I) as being dedicated to particular they judge well; but in this they fall into the error profefions. defcribed in the ancient fable, ${ }^{6}$ in which the other parts of the body did fuppofe the ftomach had been idle, becaufe it neither performed the office of motion, as the limbs do, nor of fenfe, as the head doth; but yet, notwithftanding, it is the ftomach that digefteth and diftributeth to all the reft: fo if any man think philorophy and univerfality to be idle ftudies, he doth not confider that all profeffions are from thence ferved and fupplied. And this I take to be a great caufe that hath hindered the progreffion of learning, becaufe thefe fundamental knowledges have been ftudied but in paffage. For if you will have a tree bear more fruit than it hath ufed to do, it is not anything you can do to the boughs, but it is the ftirring of the earth and putting new mould about the roots that muft work it. Neither is it to be forgotten, that this dedicating of foundations and dotations to pro-

4 Orat. poft Redit. in Sen. xii. 30, which in Bacon's day was counted genuine. The actual paffage is fomething ftronger; for it has nefas inftead of ingratum.

5 Philip. iii. 13.

6 Liv. ii. 32. 
98 ADVANCEMENT OF LEARNING.

feffory learning hath not only had a malign afpect and influence upon the growth of fciences, but hath alfo been prejudicial to ftates and governments. For hence it proceedeth that princes find a folitude in regard of able men to ferve them in caufes of ftate, becaufe there is no education collegiate which is free; where fuch as were fo difpofed might give themfelves to hiftories, modern languages, books of policy and civil difcourfe, and other the like enablements unto fervice of eftate.

(2) As ill provided with public lectures.

And becaufe Founders of Colleges do plant, and Founders of Lectures do water, it followeth well in order to fpeak of the defect which is in public lectures; namely, in the fmallnefs and meannefs of the falary or reward which in moft places is affigned unto them; whether they be lectures of arts, or of profeffions. For it is neceffary to the progreffion of fciences that Readers be of the moft able and fufficient men; as thofe which are ordained for generating and propagating of fciences, and not for tranfitory ufe. This cannot be, except their condition and endowment be fuch as may content the ablelt man to appropriate his whole labour and continue his whole age in that function and attendance; and therefore muft have a proportion anfwerable to that mediocrity or competency of advancement, which may be expected from a profeffion or the practice of a profeffion. So as, if you will have fciences flourih, you muft obferve David's military law, which was, That thoje which flaid with the carriage fhould have 
equal part with thoje which were in the action; ${ }^{7}$ elfe will the carriages be ill attended. So Readers in fciences are indeed the guardians of the ftores and provifions of fciences, whence men in active courfes are furnifhed, and therefore ought to have equal entertainment with them : otherwife if the fathers in fciences be of the weakeft fort, or be illmaintained,

Et patrum invalidi referent jejunia nati. ${ }^{6}$

Another defect I note, wherein I thall need fome alchemift to help me, who call upon men to fell their books, and to build furnaces; quitting (3) As to means for inquiry and forfaking Minerva and the Mufes as barren virgins, and relying upon Vulcan.9 But certain it is, that unto the deep, fruitful, and operative ftudy of many fciences, efpecially Natural Philofophy and Phyfic, books be not the only inftrumentals; wherein alfo the beneficence of men hath not been altogether wanting: for we fee fpheres, globes, aftrolabes, maps, and the like, have been provided as appurtenances to aftronomy and cofmography, as well as books : we fee likewife that fome places inftituted for phyfic have annexed the commodity of gardens for fimples of all forts, and do likewife command the ufe of dead bodies for anatomies. But thefe do refpect but a few things. In general, there will hardly be any main proficience in the difclofing of nature, except there be fome

7 I Sam. xxx. 22.

8 Virg. Gcorg. iii. 128.

9 See Nov. Org. ii. 7: "Tranfeundum plane a Vulcano ad Minervam, $f_{2}$ in animo fit veras corporum texturas et fchem.timos .... in lucem protrahere." 


\section{IO० ADVANCEMENT OF LEARNING.}

allowance for expenfes about experiments; whether they be experiments appertaining to Vulcanus or Dædalus, furnace or engine, or any other kind: and therefore as fecretaries and fpials of princes and ftates bring in bills for intelligence, fo you muft allow the fpials and intelligencers of nature to bring in their bills; or elfe you thall be ill advertifed.

And if Alexander made fuch a liberal affignation to Ariftotle of treafure ${ }^{10}$ for the allowance of hunters, fowlers, fifhers, and the like, that he might compile a Hiftory of Nature, much better do they deferve it that travail in Arts of Nature. ${ }^{11}$

(4) As to the careleftneis of Vifitors.
Another defect which I note, is an intermiffion or neglect in thofe which are governors in univerfities, of confultation; and in princes or fuperior perfons, of vifitation : to enter into account and confideration, whether the readings, exercifes, and other cuftoms appertaining unto learning, anciently begun, and fince continued, be well inftituted or no; and thereupon to ground an amendment or reformation in that which thall be found inconvenient. For it is one of your majefty's own moft wife and princely maxims, That in all

10 Alian, Var. Hif..iv. 19, fays that Philip helped him, and A thenæus, ix. 398. f. ftates the amount faid to have been allowed him by Alexander, 800 talents. But Bacon takes his ftatement here trom Plin. Nat. Hift. viii. 17.

"The Latin has for "travail in arts of Nature," " in labyrin. tbis artium viam fibi aperiunt," -where Art is oppofed to Nature. So that the phrafe "Arts of Nature" muft be modified to mean "Arts concerned with Nature." Or, poffibly, there is fome miftake in the reading. All the old editions have travailes. If the reading is correct, the fenfe will be that they who lay down rules and general principles of Arts in things Natural are worthy of higher reward than are they who only collect Hiftories, i.e. catalogues or regifters of detached facts. 
ufages and precedents, the times be confidered wherein they firf began; which, if they were rueak or ignorant, it derogateth from the autbority of the ufage, and leaveth it for jujpect. And therefore inafmuch as moft of the urages and orders of the univerfities were derived from more obfcure times, it is the more requifite they be re-examined. In this kind I will give an inftance or two, for example fake, of things that are the moft obvious and familiar. The one is a matter, which though it be ancient and general, yet I hold to be an error; which is, that fcholars in univerfities come too foon and too unripe to logic and rhetoric, arts fitter for graduates than children and novices: for thefe two, rightly taken, are the graveft of fciences, being the arts of arts; the one for judgment, the other for ornament: and they be the rules and directions how to fet forth and difpofe matter; and therefore for minds empty and unfraught with matter, and which have not gathered that which Cicero calleth Sylva and Supellex, ${ }^{12}$ ftuff and variety, to begin with thofe arts, (as if one hould learn to weigh, or to meafure, or to paint the wind), doth work but this effect, that the wifdom of thofe arts, which is great and univerfal, is almoft made contemptible, and is degenerate into childifh fophiftry and ridiculous affectation. And further, the untimely learning of them hath drawn on, by confequence, the fuperficial and unprofitable teaching and writing of them, as fitteth indeed to the capacity of children. Another is a lack I

12 Sylva, de Orat. iii. 26. (103.) Supellex, Orat. 24. (80.) 


\section{I02 ADVANCEMENT OF LEARNING.}

find in the exercifes ufed in the Univerfities, which do make too great a divorce between invention and memory; for their fpeeches are either premeditate, In verbis conceptis, where nothing is left to invention, or merely extemporal, where little is left to memory: whereas in life and action there is leaft ufe of either of thefe, but rather of intermixtures of premeditation and invention, notes and memory; fo as the exercife fitteth not the practice, nor the image the life; and it is ever a true rule in exercifes, that they be framed as near as may be to the life of practice; for otherwife they do pervert the motions and faculties of the mind, and not prepare them. The truth whereof is not obfcure, when fcholars come to the practices of profeflions, or other actions of civil life; which when they fet into, this want is foon found by themfelves, and fooner by others. But this part, touching the amendment of the inftitutions and orders of Univerfities, I will conclude with the claufe of Cæfar's letter to Oppius and Balbus, $\mathrm{Hoc}$ quemadmodum feri polfit, nonnulla mibi in mentem veniunt, et multa reperiri poffunt; de iis rebus rogo vos ut cogitationem $\int u$ cipiatis. ${ }^{13}$

(5) As to

Another defect which I note, afcendeth a little intercourfe Univerfities. cience of learning confifteth much in the orders and inftitutions of Univerfities in the fame ftates and kingdoms, fo it would be yet more advanced, if there were more intelligence mutual between. the Univerfities of Europe than now there is. 
We fee there may be many orders and foundations, which though they be divided under feveral fovereignties and territories, yet they take themfelves to have a kind of contract, fraternity, and correfpondence one with the other; infomuch as they have provincials and generals. And furely, as nature createth brotherhood in families, and arts mechanical contract brotherhoods in commonalties, and the anointment of God fuperinduceth a brotherhood in kings and bihhops; fo in like manner there cannot but be a fraternity in learning and illumination, relating to that paternity which is attributed to God, who is called the Father of illumirnations or lights. ${ }^{14}$

The laft defect which I will note is, that there hath not been, or very rarely been, any public defignation of writers or inquirers concerning fuch parts of knowledge as may appear not to have been already fufficiently laboured or undertaken; (6) No perfons appointed to inquire into deficient branches of learning. unto which point it is an inducement to enter into a view and examination what parts of learning have been profecuted, and what omitted: for the opinion of plenty is among the caufes of want, and the great quantity of books maketh a how rather of fuperfluity than lack; which furcharge, neverthelefs, is not to be remedied by making no more books, but by making more good books, which, as the ferpent of Mofes, might devour the ferpents of the enchanters. ${ }^{15}$

The removing of all the defects formerly enu-

14 James i. 17.

15 Exod, vii. Io. It was Aaron's rod that became a ferpent.

The removal of 


\section{ADVANCEMENT OF LEARNING.}

thefe defects merated, except the laft, and of the active part the work of

kings, except part of the laft, i.e. the furvey of lersning, which I will now attempt. alfo of the laft, (which is the defignation of writers, ) are opera bafilica; towards which the endeavours of a private man may be but as an image in a croffway, that may point at the way, but cannot go it : but the inducing part of the latter, which is the furvey of learning, may be fet forward by private travail. Wherefore I will now attempt to make a general and faithful perambulation of learning, with an inquiry what parts thereof lie frefh and wafte, and not improved and converted by the induitry of man; to the end that fuch a plot made and recorded to memory, may both minifter light to any public defignation, and alfo ferve to excite voluntary endeavours: wherein, neverthelefs, my purpofe is at this time to note only omiflions and deficiencies, and not to make any redargution of errors or incomplete profecutions; for it is one thing to fet forth what ground lieth unmanured, and another thing to correct ill hufbandry in that which is manured.

In the handling and undertaking of which work I am not ignorant what it is that I do now move and attempt, nor infenfible of mine own weaknefs to fuftain my purpole; but my hope is, that if my extreme love to learning carry me too far, I may obtain the excure of affection; for that It is not granted to man to love and to be wife. ${ }^{16}$ But I know well I can ufe no other liberty of judgment than I muft. leave to others; and I for my part $\mathrm{fhall}$ be indifferently glad either to perform myfelf, or accept

${ }^{16}$ Publ. Syr. Sentent. 166: Amare et fapere vix Deo conceditur. 
from another, that duty of humanity; Nam qui erranti comiter monfrat viam, $\mathcal{E}^{2} c .{ }^{17}$ I do forefee likewife that of thofe things which I thall enter and regifter as deficiencies and omiffions, many will conceive and cenfure that fome of them are already done and extant; others to be but curiofities, and things of no great ufe; and others to be of too great difficulty, and almoft impoffibility to be compaffed and effected. But for the two firft, I refer myfelf to the particulars; for the laft, touching impoffibility, I take it thofe things are to be held poffible which may be done by fome perfon, though not by every one ; and which may be done by many, though not by any one ; and which may be done in the fucceflion of ages, though not within the hourglafs of one man's life ; and which may be done by public defignation, though not by private endeavour. But, notwithftanding, if any man will take to himfelf rather that of Salomon, Dicit piger, Leo eft in via, ${ }^{18}$ than that of Virgil, Pofunt quia polfe videntur, ${ }^{19}$ I thall be content that my labours be efteemed but as the better fort of wifhes: for as it afketh fome knowledge to demand a queftion not impertinent, fo it required fome fenfe to make a wifh not abfurd.

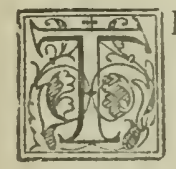

in

7 E
De Aug. II. i. Human Learning is triple, according to the three parts of the mind. 


\section{ADVANCEMENT OF LEARNING.}

(1.) Hiftory to his imagination, and pbilofopby to his reafon. t.o Memory. Divine learning receiveth the fame diftribution; to Imagina- for the fpirit of man is the fame, though the revetion.

(3.) Philofophy to Realon. lation of oracle and fenfe be diverfe : fo as theology confifteth alfo of the biftory of the church; of parables, which is divine poefy; and of holy doctrine or prccept: for as for that part which feemeth fupernumerary, which is prophecy, it is but Divine Hiftory; which hath that prerogative over human, as the narration may be before the fact as well as after.

De Aug. 1r. Hiftory is natural, civil, ecclefiafical, and liteI. Hiftory. rary; whereof the firft three I allow as extant, the (r.) Natu- fourth I note as deficient. For no man hath proral.

(2.) Civil. pounded to himfelf the general ftate of learning to (3.) Ecclefi-be defcribed and reprefented from age to age, as aftical.

(4.) Literary.

many have done the works of nature, and the ftate civil and ecclefiaftical; without which the hiftory of the world feemeth to me to be as the ftatua of Polyphemus with his eye out; that part being wanting which doth moft thow the fpirit and life of the perfon: and yet I am not ignorant that in divers particular fciences, as of the jurifconfults, the mathematicians, the rhetoricians, the philofophers, there are fet down fome fmall memorials of the fchools, authors, and books; and fo likewife fome barren relations touching the invention of arts or ufages. But a juft ftory of learning, containing the antiquities and originals of knowledges and their fects, their inventions, their traditions, their diverfe adminiftrations and managings, their flourifhings, their oppofitions, decays, depreffions, oblivions, removes, with the caufes and occa- 
fions of them, and all other events concerning learning, throughout the ages of the world, I may truly affirm to be wanting. The ufe and end of which work I do not fo much defign for curiofity or fatisfaction of thofe that are the lovers of learning, but chiefly for a more ferious and grave purpofe; which is this in few words, that it will make learned men wife in the ufe and adminiftration of learning. For it is not St. Auguftine's nor St. Ambrofe's works that will make fo wife a divine, as ecclefiaftical hiftory, thoroughly read and obferved; and the fame reafon is of learning.

Hiftory of nature is of three forts; of nature in DeAug. 11. courfe, of nature erring or varying, and of nature altered or wrought; that is, biftory of creatures, bifory of marvels, and biftory of arts. The firft of thefe, no doubt, is extant, and that in good 2.

(I.) Natural. perfection; the two latter are handled fo weakly and unprofitably, as I am moved to note them as deficient. For I find no fufficient or competent collection of the works of nature which have a digreffion and deflection from the ordinary courfe of gerierations, productions, and motions; whether they be fingularities of place and region, or the Atrange events of time and chance, or the effects of yet unknown properties, or the inftances of exception to general kinds. It is true, I find a number of books of fabulous experiments and fecrets, and frivolous impoftures for pleafure and ftrangenefs; but a fubftantial and fevere collection of the beteroclites or irregulars of nature, ${ }^{20}$ well ${ }^{20} \mathrm{Cf}$. Nov, Org. i, 45, and ii. 28. Thefe "inftances of ex- 


\section{IO8 ADVANCEMENT OF LEARNING.}

examined and defcribed, I find not: efpecially not with due rejection of fables and popular errors: for as things now are, if an untruth in nature be once on foot, what by reafon of the neglect of examination and countenance of antiquity, and what by reafon of the ufe of the opinion in fimilitudes and ornaments of fpeech, it is never called down.

(b) Of Marvels.

The ufe of this work, honoured with a precedent in Ariftole, 21 is nothing lefs than to give contentment to the appetite of curious and vain wits, as the manner of Mirabilaries $\Omega 2$ is to do ; but for two reafons, both of great weight; the one to correct the partiality of axioms and opinions, which are commonly framed only upon common and familiar examples; the other becaufe from the wonders of nature is the neareft intelligence and paffage towards the wonders of art: for it is no more but by following, and as it were hounding nature in her wanderings, to be able to lead her afterwards to the fame place again. Neither am I of opinion, in this hiftory of marvels, that fuperftitious narrations of forceries, witchcrafts, dreams, divinations, and the like, where there is an affurance and clear evidence of the fact, be altogether excluded. For it is not yet known in what cafes and how far effects attributed to fuperftition do participate of natural caufes: and therefore howfoever the practice of fuch things is to be condemned, yet from the fpeculation and confideration ception to general kinds" he there terms infantice monodica, quas etiam irregulares five beteroclitas appellare conluevimus.

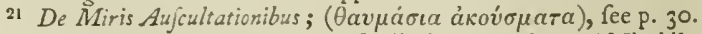

${ }_{22}$ Mirabilaries. In $D_{e}$ Augm. Sco. ii. he calls them "Mirabilarii et prodigiaftri." 
of them light may be taken, not only for the difcerning of the offences, but for the further difclofing of nature. Neither ought a man to make fcruple of entering into thefe things for inquifition of truth, as your Majefty hath howed in your own example; who with the two clear eyes of religion and natural philofophy have looked deeply and wifely into thefe fhadows, and yet proved yourfelf to be of the nature of the fun, which paffeth through pollutions, and itfelf remains as pure as before. ${ }^{23}$ But this $I$ hold fit, that thefe narrations, which have mixture with fuperftition, be forted by themfelves, and not be mingled with the narrations which are merely and fincerely natural. But as for the narrations touching the prodigies and miracles of religions, they are either not true, or not natural ; and therefore impertinent for the ftory of nature.

For biftory of nature wrought or mechanical, I find fome collections made of agriculture, and like(c) Of Arts. wife of manual arts ; but commonly with a rejection of experiments familiar and vulgar. For it is efteemed a kind of difhonour unto learning to defcend to inquiry or meditation upon matters mechanical, except they be fuch as may be thought fecrets, rarities, and fpecial fubtilties; which humour of vain and fupercilious arrogancy is juftly derided in Plato; where he brings in Hippias, a vaunting fophift, difputing with Socrates, a true and unfeigned inquifitor of truth; where the fubject being touching beauty, Socrates, after his

${ }^{23} \mathrm{Cf}$. Nov. Org. i. I20. This thought is to be met with in Chaucer, Perfone's Tale: "Certes, Holy Writ may not be derouled, no mure than the fonne that fhineth on the myxene." 


\section{IO $A D V A N C E M E N T$ OF LEARNING.}

wandering manner of inductions, put firft an example of a fair virgin, and then of a fair horfe, and then of a fair pot well glazed, whereat Hippias was offended, and faid, More than for courtefy's fake, be did think much to difpute with any that did allege fucb bafe and fordid inftances: whereunto Socrates anfwered, You bave reafon, and it becomes you well, being a man fo trim in your veftments, Eंc. and fo goeth on in an irony. ${ }^{2+}$ But the truth is, they be not the higheft inftances that give the fecureft information; as may be well expreffed in the tale fo common of the philofopher, 25 that while he gazed upwards to the ftars fell into the water; for if he had looked down he might have feen the ftars in the water, but looking aloft he could not fee the water in the ftars. So it cometh often to pafs, that mean and fmall things difcover great, better than great can difcover the fmall: and therefore Ariftotle noteth well, That the nature of everything is beft feen in its fmalleft portions. And for that caufe he inquireth the nature of a commonwealth, firft in a family, and the fimple conjugations of man and wife, parent and child, mafter and fervant, which are in every cottage. ${ }^{26}$ Even fo likewife the nature of this great city of the world, and the policy thereof, muft be firft fought in mean concordances and fmall portions. So we fee how that fecret of nature, of the turning of iron touched with the loadftone towards the north, was found out in needles of iron, not in bars of iron.

\#4 Plato, Hipp. Maj. iii. 288 and 291.

25 Thales. See Plat. Theat. i. 174.

26 Ariftot. Polit. I. iii. 1, and Pbys. i. 
But if my judgment be of any weight, the ufe of biffory mechanical is of all others the moft radi$\mathrm{cal}$ and fundamental towards natural philofophy; fuch natural philofophy as thall not vanifh in the fume of fubtile, fublime, or delectable fpeculation, but fuch as thall be operative to the endowment and benefit of man's life: for it will not only minifter and fuggeft for the prefent many ingenious practices in all trades, by a connection and transferring of the obfervations of one art to the ufe of another, when the experiences of feveral myrteries thall fall under the confideration of one man's mind; but further, it will give a more true and real illumination concerning caufes and axioms than is hitherto attained. For like as a man's difpofition is never well known till he be croffed, nor Proteus ever changed fhapes till he was fraitened and held faft; $;$ fo the paffages and variations of nature cannot appear fo fully in the liberty of nature, as in the trials and vexations of art.

For civil biftory, it is of three kinds; not unfitly to be compared with the three kinds of pictures or images : for of pictures or images, we fee fome De Aug. I1. 6. (2.) $O f$ Civil Hifare unfinithed, fome are perfect, and fome are detory. faced. So of hiftories we may find three kinds, memorials, perfect biftories, and antiquities; for memorials are hiftory unfinifhed, or the firft or rough draughts of hiftory; and antiquities are hiftory defaced, or fome remnants of hiftory which have cafually efcaped the fhipwreck of time. 


\section{II2 $A D V A N C E M E N T$ OF LEARNING.}

(a) Memorials.

Memorials, or preparatory biftory, are of two forts; whereof the one may be termed commentaries, and the other regifters. Commentaries are they which fet down a continuance of the naked events and actions, without the motives or defigns, the counfels, the fpeeches, the pretexts, the occafions and other paffages of action: for this is the true nature of a commentary; though Cæarar, in modefty mixed with greatnefs, did for his pleafure apply the name of a commentary to the beft hiftory of the world. Regifters are collections of public acts, as decrees of council, judicial proceedings, declarations and letters of ftate, orations and the like, without a perfect continuance or contexture of the thread of the narration.

(b) Anti. quities.

Antiquities, or remnants of hiftory, are, as was faid, Tanquam tabula naufragii; ${ }^{28}$ when induftrious perfons by an exact and fcrupulous diligence and obfervation, out of monuments, names, words, proverbs, traditions, private records and evidences, fragments of ftories, paffages of books that concern not ftory, 99 and the like, do fave and recover fomewhat from the deluge of time.

In thefe kinds of unperfect hiftories I do affign no deficience, for they are Tanquam imperfecte mifta; and therefore any deficience in them is but their nature. As for the corruptions and moths of hiftory, which are epitomes, the ufe of them deferveth to be banithed, as all men of found judgment have confefled; as thofe that have fretted 28 "As was faid ;" referring to the laft page. Cf. Nov. Org. i. 77.

${ }_{29}$ Story here $=$ hiftory : "librorum neutiquam hiftoricorum." 
and corroded the found bodies of many excellent hiftories, and wrought them into bafe and unprofitable dregs. ${ }^{30}$

Hiftory, which may be called juft and perfect hiftory, is of three kinds, according to the object which it propoundeth or pretendeth to reprefent: for it either reprefenteth a time, or a perfon, or an astion. The firft we call cbronicles, the fecond lives, and the third narrations or relations. Of thefe, although the firft be the moft complete and abfolute kind of hiftory, and hath moft eftimation and glory, yet the fecond excelleth it in profit and ufe, and the third in verity and fincerity. For hiftory of times reprefenteth the magnitude of actions, and the public faces and deportments of perfons, and paffeth over in filence the fmaller paffages and motions of men and matters. But fuch being the workmannip of God, as $\mathrm{He}$ doth hang the greateft weight upon the fmalleft wires, Maxima ì minimis Jufpendens, ${ }^{31}$ it comes therefore to pafs, that fuch hiftories do rather fet forth the pomp of bufinefs than the true and inward reforts thereof. But lives, if they be well written, propounding to themfelves a perfon to reprefent in whom actions both greater and fmaller, public and private, have a commixture, muft of neceffity contain a more true, native, and lively reprefentation. So again narrations and relations of actions, as the war of Peloponnefus, the expedition of Cyrus Minor, the confpiracy of Catiline, cannot but be

De Aug.

II. 7.

(c.) Perfect Hiftory.

i. Chronicles. 


\section{4 DVANCEMENT OF LEARNING.}

more purely and exactly true than hiftories of times, becaufe they may choofe an argument comprehenfible within the notice and inftructions of the writer: whereas he that undertaketh the ftory of a time, efpecially of any length, cannot but meet with many blanks and fpaces which he muft be forced to fill up out of his own wit and conjecture.

For the Hiftory of Times, I mean of Civil Hiftory, the providence of God hath made the difribution: for it hath pleafed God to ordain and illuftrate two exemplar ftates of the world for arms, learning, moral virtue, policy, and laws; the ftate of Græcia, and the ftate of Rome; the hiftories whereof occupying the middle part of time, have more ancient to them, hiftories which may by one common name be termed the antiquities of the world : and after them, hiftories which may be likewife called by the name of modern biftory.

a. Ancient. Now to fpeak of the deficiencies. As to the beathen antiquities of the world, it is in vain to note them for deficient: deficient they are no doubt, confifting moft of fables and fragments; but the deficience cannot be holpen; for antiquity is like fame, Caput inter nubila condit, ${ }^{31}$ her head is muffled from our fight. For the hiftory of the exemplar fates, it is extant in good perfection. Not but I could wifh there were a perfect courfe of hiftory for Græcia from Thefeus to Philopœmen, (what time the affairs of Græcia were drowned and extinguifhed in the affairs of Rome;) and for Rome from Romulus to Juftinianus, who may be truly 
faid to be Ultimus Romanorum.32 In which fequences of ftory the text of Thucydides and Xenophon in the one, and the texts of Livius, Polybius, Salluftius, Cæfar, Appianus, Tacitus, Herodianus in the other, to be kept entire without any diminution at all, and only to be fupplied and continued. But this is matter of magnificence, rather to be commended than required: and we fpeak now of parts of learning fupplemental and not of fupererogation.

But for modern biftories, whereof there are fome $\beta$. Modern. few very worthy, but the greater part beneath mediocrity, (leaving the care of foreign ftories to foreign ftates, becaufe I will not be curiofus in aliena republica, ${ }^{33}$ ) I cannot fail to reprefent to your Majefty the unworthinefs of the hiftory of England in the main continuance thereof, and the partiality and obliquity of that of Scotland in the lateft and largeft author that I have feen : ${ }^{34}$ fuppofing that it would be honour for your Majefty, and a work very memorable, if this ifland of Great Britain, as it is now joined in monarchy for the ages to come, fo were joined in one hiftory for the times paffed; after the manner of the Sacred Hiftory, which draweth down the ftory of the ten tribes and of the two tribes, as twins, together. And if it thall feem that the greatnefs of this work may make it lefs exactly performed, there is an excellent period

32 Said of Caffius, Tac. Ann. iv. 34. "Cremutius Cordus poftulatur,... quod C. Calfium Romanorum ultimum dixiffet." Cf. Plut. Brutus, 43. Suet. Tib. 61. who attributes it to both Brutus and Cafius.

33 Cic. Off. i. 34.

s4 Buchanan, for whom King James had no love. 


\section{ADVANCEMENT OF LEARNING.}

of a much fmaller compars of time, as to the ftory of England; that is to fay, from the uniting of the Rofes to the uniting of the kingdoms; a portion of time, wherein, to my underftanding, there hath been the rareft varieties that in like number of fucceffions of any hereditary monarchy hath been known. For it beginneth with the mixed adoption of a crown by arms and title: an entry by battle, an eftablifhment by marriage, and therefore times anfwerable, like waters after a tempeft, full of working and fwelling, though without extremity of ftorm; but well paffed through by the widdom of the pilot, being one of the moft fufficient kings of all the number. Then followeth the reign of a king, whofe actions, howfoever conducted, had much intermixture with the affairs of Europe, balancing and inclining them variably; in whore time alfo began that great alteration in the ftate ecclefiaftical, an action which feldom cometh upon the ftage. Then the reign of a minor: then an offer of a ufurpation, though it was but as febris epbemera. Then the reign of a queen matched with a foreigner: then of a queen that lived folitary and unmarried, and yet her government fo mafculine, that it had greater impreffion and operation upon the ftates abroad than it any ways received from thence. And now laft, this moft happy and glorious event, that this inand of Britain, divided from all the world, ${ }^{35}$ fhould be united in itfelf: and that oracle of reft, given to Eneas, antiquam exquirite ma${ }^{33}$ Virg. Ecl. i. 67 . 
trem, ${ }^{36}$ thould now be performed and fulfilled upon the nations of England and Scotland, being now reunited in the ancient mother name of Britain, as a full period of all inftability and peregrinations. So that as it cometh to pafs in maffive bodies, that they have certain trepidations and waverings before they fix and fettle; fo it feemeth that by the providence of God this monarchy, before it was to fettle in your majefty and your generations, (in which I hope it is now eftablifhed for ever, ) had thefe prelufive changes and varieties.

For lives, I do find it ftrange that thefe times ii. Lives. have fo little efteemed the virtues of the times, as that the writing of lives fhould be no more frequent. For although there be not many fovereign princes or abfolute commanders, and that ftates are moft collected into monarchies, yet are there many worthy perfonages that deferve better than difperfed report or barren elogies. For herein the invention of one of the late poets ${ }^{37}$ is proper, and doth well enrich the ancient fiction: for he feigneth that at the end of the thread or web of every man's life there was a little medal containing the perfon's name, and that Time waited upon the fhears; and as foon as the thread was cut, caught the medals, and carried them to the river of Lethe; and about the bank there were many birds flying up and down, that would get the medals and carry

36 Virg. 2 n. iii. 96.

37 Ariofto, Orlando Furiofo, end of Bk. 34, and opening of Bk. 35. (See Ellis' and Spedding's Ed. of the De Augm. Sc.) 


\section{II $8 D V A N C E M E N T$ OF LEARNING.}

them in their beak a little while, and then let them fall into the river: only there were a few fwans, which if they got a name, would carry it to a temple where it was confecrate. And although many men, more mortal in their affections than in their bodies, do efteem defire of name and memory but as a vanity and ventofity,

Animi nil magnæ laudis egentes $;^{38}$

which opinion cometh from that root, Non prius laudes contempfimus, quam laudanda facere defivimus: ${ }^{39}$ yet that will not alter Salomon's judgment, Memoria jufti cum laudibus, at impiorum nomen putrefcet: ${ }^{40}$ the one flourifheth, the other either comfumeth to prefent oblivion, or turneth to an ill odour. And therefore in that ftyle or addition, which is and hath been long well received and brought in ufe, Felicis memoria, pice memorice, bonee memoria, we do acknowledge that which Cicero faith, borrowing it from Demofthenes, that Bona fama propria polfeflo defunctorum; ${ }^{41}$ which poffeffion I cannot but note that in our times it lieth much wafte, and that therein there is a deficience.

iii. Narrations.

For narrations and relations of particular actions, there were alfo to be wifhed a greater diligence therein; for there is no great action but hath fome good pen which attends it. And becaufe it is an

38 Virg. $\not E n . v .75$ r.

39 Plin. Ep. iii. 21. "Pofquam defiimus facere laudanda, laudari quoque ineptum putamus." Were Bacen's quotations ufually from memory?

40 Prov. $\mathrm{x} .7$.

41 Cic. Pbilip. ix. "Vita enim mortuorum in memoria vivorum

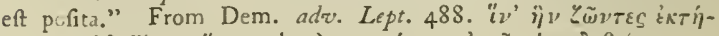

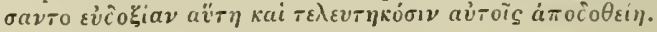


ability not common to write a good hiftory, as may well appear by the fmall number of them; yet if particularity of actions memorable were but tolerably reported as they pass, the compiling of a complete hiftory of times mought be the better expected, when a writer thould arife that were fit for it : for the collection of fuch relations mought be as a nurfery garden, whereby to plant a fair and ftately garden, when time fhould ferve.

There is yet another portion of hiftory which Cornelius Tacitus maketh, which is not to be forgotten, efpecially with that application which he accoupleth it withal, annals and journals: appropriating to the former matters of eftate, and to the latter acts and accidents of a meaner nature. For giving but a touch of certain magnificent buildings, he addeth, Cum ex dignitate populi Romani repertum fit, res illuftres annalibus talia diurnis urbis actis mandare. ${ }^{2}$ So as there is a kind of contemplative heraldry, as well as civil. And as nothing doth derogate from the dignity of a ftate more than confufion of degrees; fo it doth not a little embare the authority of a hiftory, to intermingle matters of triumph, or matters of ceremony, or matters of novelty, with matters of ftate. But the ufe of a journal hath not only been in the hiftory of time, but likewife in the hiftory of perfons, and chiefly of actions; for princes in ancient time had, upon point of honour and policy both, journals kept of what paffed day by day: for we fee the chronicle which was read before 


\section{I20 ADVANCEMENT OF LEARNING.}

Ahafuerus, ${ }^{43}$ when he could not take reft, contained matter of affairs indeed, but fuch as had paffed in his own time, and very lately before: but the journal of Alexander's houfe expreffed every fmall particularity, even concerning his perfon and court; ${ }^{44}$ and it is yet a ufe well received in enterprifes memorable, as expeditions of war, navigations, and the like, to keep diaries of that which paffeth continually.

De Aug. ii. I cannot likewife be ignorant of a form of writ10.

Efiays on Hiftory come under Policy. ing which fome wife and grave men have ufed, containing a fcattered hiftory of thofe actions which they have thought worthy of memory, with politic difcourfe and obfervation thereupon: not incorporate into the hiftory, but feparately, and as the more principal in their intention $;^{45}$ which kind of ruminated biffory I think more fit to place amongft books of policy, whereof we thall hereafter fpeak, than amongft books of hiftory: for it is the true office of hiftory to reprefent the events themfelves together with the counfels, and to leave the obfervations and conclufions thereupon to the liberty and faculty of every man's judgment. But mixtures are things irregular, whereof no man can define.

v. Cofmography or travels and mathematics on their phyfical fide.
So alfo is there another kind of hiftory manifoldly mixed, and that is biftory of cofmography: being compounded of natural hiftory, in refpect of the regions themfelves; of hiftory civil, in refpect

43 Efh. vi. I.

44 See Plutarch, Sympos. i. Qu. 6.

45 Such books as Machiavelli's Difcorfi fopra Livia are here meant. 
of the habitations, regiments, and manners of the people; and the matbematics, in refpect of the climates and configurations towards the heavens: which part of learning of all others in this latter time hath obtained moft proficience. For it may be truly affirmed to the honour of thefe times, and in a virtuous emulation with antiquity, that this great building of the world had never throughlights made in it, till the age of us and our fathers: for although they had knowledge of the Antipodes,

Nofque ubi primus equis Oriens afflavit anhelis, Illic fera rubens accendit lumina Vefper : ${ }^{46}$

yet that mought be by demonftration, and not in fact; and if by travel, it requireth the voyage but of half the globe. But to circle the earth, as the heavenly bodies do, was not done or enterprifed till thefe latter times: and therefore thefe times may juftly bear in their word, not only plus ultra, ${ }^{4 \tau}$ in precedence of the ancient non ultra, and imitabile fulmen, in precedence of the ancient non imitabile fulmen,

Demens qui nimbos et non imitabile fulmen; \&c. ${ }^{48}$

but likewife imitabile colum; in refpect of the many memorable voyages after the manner of heaven about the globe of the earth.

And this proficience in navigation and difcoveries may plant alfo an expectation of the further proficience and augmentation of all fciences;

45 Virg. Georg. i. 250,25 I.

47 Plus ultra was the motto of Charles V. (Ellis.)

48 Virg. AEn. vi. 590. 


\section{I22 ADVANCEMENT OF LEARNING.}

becaufe it may feem they are ordained by God to be coevals, that is, to meet in one age. For fo the prophet Daniel, fpeaking of the latter times, foretelleth Plurimi pertranfibunt, et multiplex erit fcientia $:^{49}$ as if the opennefs and thorough paffage of the world and the increafe of knowledge were appointed to be in the fame ages; as we fee it is already performed in great part; the learning of thefe latter times not much giving place to the former two periods or returns of learning, the one of the Grecians, the other of the Romans.

De Aug.

II. I I.

(3.) Ecclefiaftical Hiftory.

(a.) Of the Church.

Hiftory ecclefiafical receiveth the fame divifions with hiftory civil: but further, in the propriety thereof, may be divided into the biftory of the church, by a general name; hiftory of prophecy; and biftory of providence. The firft defcribeth the times of the militant church, whether it be fluctuant, as the ark of Noah; or moveable, as the ark in the wildernefs; or at reft, as the ark in the temple: that is, the ftate of the church in perfecution, in remove, and in peace. This part I ought in no fort to note as deficient; only I would that the virtue and fincerity of it were according to the mafs and quantity. But I am not now in hand with cenfures, but with omiffions.

(b.) OfPro- The fecond, which is biftory of prophecy, conphecy. fifteth of two relatives, the prophecy, and the accomplifhment; and therefore the nature of fuch a work ought to be, that every prophecy of the Scripture be forted with the event fulfilling the fame, throughout the ages of the world; both for 
better confirmation of faith, and for the better illumination of the Church touching thofe parts of prophecies which are yet unfulfilled: allowing neverthelefs that latitude which is agreeable and familiar unto divine prophecies; being of the nature of their Author, with whom a thoufand years are but as one day; ${ }^{50}$ and therefore are not fulfilled punctually at once, but have fpringing and germinant accomplifhment throughout many ages; though the height or fulnefs of them may refer to fome one age. This is a work which I find deficient; but is to be done with wifdom, fobriety, and reverence, or not at all.

The third, which is biftory of providence, con- (c.) Of Protaineth that excellent correfpondence which is bevidence.

tween God's revealed will and His fecret will : which though it be fo obfcure, as for the moft part it is not legible to the natural man; no, nor many times to thofe that behold it from the $\mathrm{Ta}$ bernacle; yet at fome times it pleafeth God, for our better eftablifhment and the confuting of thofe which are as without God in the world, to write it in fuch text and capital letters, that as the prophet faith, $H e$ that runneth by may read it ${ }^{51}$ that is, mere fenfual perfons, which haften by God's judgments, and never bend or fix their cogitations upon them, are neverthelefs in their paffage and race urged to difcern it. Such are the notable events and examples of God's judgments, chaf-

$50 \quad 2$ Peter iii. 8.

sl Hab. ii. 2. but mifquoted. "That he may run that readeth," -i.e. may haften to carry on the tidings. 


\section{$124 A D V A N C E M E N T$ OF LEARNING.}

tifements, deliverances, and bleffings : and this is a work which hath paffed through the labour of many, and therefore I cannot prefent as omitted.

De Aug.n. There are alfo other parts of learning which 2.

(4.) There are appendices to biftory: for all the exterior proarealfo Ap-ceedings of man confift of words and deeds: pendices to Hiftory ; or Literary Hiftory. whereof hiftory doth properly receive and retain in memory the deeds : and if words, yet but as inducements and paffages to deeds: fo are there other books and writings, which are appropriate to the cuftody and receipt of words only; which likewife are of three forts: orations, letters, and brief fpeeches or fayings. Orations are pleadings, fpeeches of counfel, laudatives, invectives, apologies, reprehenfions, orations of formality or ceremony, and the like. Letters are according to all the variety of occafions, advertifements, advices, directions, propofitions, petitions, commendatory, expoftulatory, fatisfactory, of compliment, of pleafure, of difcourfe, and all other paffages of action. And fuch as are written from wife men, are of all the words of man, in my judgment, the beft ; for they are more natural than orations and public fpeeches, and more advifed than conferences or prefent fpeeches. So again letters of affairs from fuch as manage them, or are privy to them, are of all others the beft inftructions for hiftory, and to a diligent reader the beft hiftories in themfelves. For Apophthegms, it is a great lofs of that book of Cæan's ; ${ }^{52}$ for as his hiftory, and thofe few letters of his which we have, and thofe apophthegms 52 Vid. Cic. ad Fam. ix. I6. 
which were of his own, excel all men's elfe, fo I fuppofe would his collection of Apophthegms have done; for as for thofe which are collected by others, either I have no tafte in fuch matters, or elfe their choice hath not been happy. But upon thefe three kinds of writings I do not infift, becaufe I have no deficiencies to propound concerning them.

Thus much therefore concerning hiftory; which is that part of learning which anfwereth to one of the cells, domiciles, or offices of the mind of man: which is that of memory.

Poefy is a part of learning in meafure of words De Aug. II. for the moft part reftrained, but in all other points extremely licenfed, and doth truly refer to the II. Puetry. imagination; which, being not tied to the laws of matter, may at pleafure join that which nature hath fevered, and fever that which nature hath joined; and fo make unlawful matches and divorces of things; Pictoribus atque poetis, $\Theta^{\circ} c^{53}$ It is taken in two fenfes in refpect of words or matter ; in the firft fenfe it is but a character of ftyle, and belongeth to arts of fpeech, and is not pertinent for the prefent: in the latter it is, as hath been faid, one of the principal portions of learning, and is nothing elfe but feigned hiftory, which may be ftyled as well in profe as in verfe.

The ufe of this feigned biftory hath been to give fome fhadow of fatisfaction to the mind of man in thofe points wherein the nature of things doth deny it, the world being in proportion inferior to

${ }^{53}$ Hor. Ep. ad Pis. 9. 
the foul; by reafon whereof there is, agreeable to the fpirit of man, a more ample greatnefs, a more exact goodnefs, and a more abfolute variety, than can be found in the nature of things. Therefore, becaufe the acts or events of true biftory have not that magnitude which fatisfieth the mind of man, poefy feigneth acts and events greater and more heroical: becaufe true biftory propoundeth the fucceffes and iffues of actions not fo agreeable to the merits of virtue and vice, therefore poefy feigns them more juft in retribution, and more according to revealed providence: becaufe true hiftory reprefenteth actions and events more ordinary, and lefs interchanged, therefore poefy endueth them with more rareneis, and more unexpected and alternative variations: fo as it appeareth that poefy ferveth and conferreth to magnanimity, morality, and to delectation. And therefore it was ever thought to have fome participation of divinenefs, becaufe it doth raife and erect the mind, by fubmitting the fhows of things to the defires of the mind; whereas reafon doth buckle and bow the mind into the nature of things. And we fee, that by thefe infinuations and congruities with man's nature and pleafure, joined alfo with the agreement and confort it hath with mufic, it hath had accefs and eftimation in rude times and barbarous regions, where other learning ftood excluded.

The divifion of Poefy which is apteft in the propriety thereof, (befides thofe divifions which are common unto it with hiftory, as feigned chronicles, feigned lives, and the appendices of hiftory, 
as feigned epiftles, feigned orations, and the reft) is into poesy narrative, reprefentative, and allufive. The Narrative is a mere imitation of hiftory, with the exceffes before remembered; choofing for fubject commonly wars and love, rarely ftate, and fometimes pleafure or mirth. Reprefentative is as a vifible hiftory; and is an image of actions as if they were prefent, as hiftory is of actions in nature as they are, (that is) paft. Allufive or Parabolical is a Narrative applied only to exprefs fome fpecial purpofe or conceit. Which latter kind of parabolical wifdom was much more in ufe in the ancient times, as by the fables of Æfop, and the brief fentences of the Seven, and the ufe of hieroglyphics may appear. And the caufe was, for that it was then of neceflity to exprefs any point of reafon which was more tharp or fubtile than the vulgar in that manner, becaufe men in thofe times wanted both variety of examples and fubtilty of conceit : and as hieroglyphics were before letters, fo parables were before arguments: and neverthelefs now, and at all times, they do retain much life and vigour; becaufe reafon cannot be fo fenfible, nor examples fo fit.

But there remaineth yet another ufe of Poefy Parabolical, oppofite to that which we laft mentioned: for that tendeth to demonftrate and illuftrate that which is taught or delivered, and this other to retire and obfcure it: that is, when the fecrets and myfteries of religion, policy, or philofophy, are involved in fables or parables. Of this in divine poefy we fee the ure is authorized. In 


\section{I28 ADVANCEMENT OF LEARNING.}

heathen poefy we fee the expofition of fables doth fall out fometimes with great felicity; as in the fable that the giants being overthrown in their war againft the gods, the Earth their mother in revenge thereof brought forth Fame:

\section{lllam terra parens, irâ irritata Deorum, \\ Extremam, ut perhibent, Cœo Enceladoque fororem Progenuit: ${ }^{54}$}

expounded, that when princes and monarchs have fuppreffed actual and open rebels, then the malignity of the people, which is the mother of rebellion, doth bring forth libels and flanders, and taxations of the ftates, which is of the fame kind with rebellion, but more feminine. So in the fable, that the reft of the gods having confpired to bind Jupiter, Pallas ${ }^{55}$ called Briareus with his hundred hands to his aid: expounded, that monarchies need not fear any curbing of their abfolutenefs by mighty fubjects, as long as by wifdom they keep the hearts of the people, who will be fure to come in on their fide. So in the fable, that Achilles was brought up under Chiron the Centaur, who was part a man and part a beaft, expounded ingenioufly but corruptly by Machiavel, 56 that it belongeth to the education and difcipline of princes to know as well how to play the part of the lion in violence, and the fox in guile, as of the man in virtue and juftice. Neverthelers, in many the like encounters, I do rather think that the fable was firft, and the expofition devifed, than that the moral was

54 Virg. AEn. iv. I78-180.

55 Not Pallas, but Thetis, Hom. Il. A. 401, J79.

s6 Hom. Il. $\Lambda .8_{3} \mathbf{I}$, and Machiav. Prince, c. 18 . 
firt, and thereupon the fable framed. For I find it was an ancient vanity in Chryfippus, that troubled himfelf with great contention to faften the affertions of the Stoics upon the fictions of the ancient poets; but yet that all the fables and fictions of the poets were but pleafure and not figure, I interpofe no opinion. Surely of thofe poets which are now extant, even Homer himfelf (notwithftanding he was made a kind of Scripture by the latter fchools of the Grecians,) yet I fhould without any difficulty pronounce that his fables had no fuch inwardnefs in his own meaning; but what they might have upon a more original tradition, is not eafy to affirm; for he was not the inventor of many of them..$^{57}$

In this third ${ }^{58}$ part of learning, which is poefy, I can report no deficience. For being as a plant that cometh of the luft of the earth, without a formal feed, it hath fprung up and fpread abroad more than any other kind. But to afcribe unto it that which is due, for the expreffing of affections, paffions, corruptions, and cuftoms, we are beholding to poets more than to the philofophers' works; and for wit and eloquence, not much lefs than to orators' harangues. But it is not good to ftay too long in the theatre. Let us now pafs on to the judicial place or palace of the mind, which we are to approach and view with more reverence and attention.

37 In the Latin, in room of thefe examples, the fables of Pan, Perfeus, and Dionyfus, are expounded to how refpectively how phyfical, political, and moral doctrines might be thence deduced.

${ }_{38}$ Rather the fecond than the sbird part of learning - Hiftory, Poefy, Philofophy. 


\section{I30 ADVANCEMENT OF LEARNING.}

De Aug. nis. I.

III. Philofophy. [Divinity being referved to the laft.]
Which is, (I.) Divine; (2.) Natural; (3.) Human.

The knowledge of man is as the waters, fome defcending from above, and fome fpringing from beneath; the one informed by the light of nature, the other infpired by divine revelation. The light of nature confifteth in the notions of the mind and the reports of the fenfes: for as for knowledge which man receiveth by teaching, it is cumulative and not original; as in a water that befides his own fpring-head is fed with other fprings and ftreams. So then, according to thefe two differing illuminations or originals, knowledge is firft of all divided into divinity and pbilofopby.

In Pbilofophy, the contemplations of man do either penetrate unto God,-or are circumferred to nature, -or are reflected or reverted upon himfelf. Out of which feveral inquiries there do arife three knowledges, divine philosopby, natural philoSophy, and buman philofophy or bumanity. For all things are marked and ftamped with this triple character, of the power of God, the difference of nature, and the ufe of man. But becaufe the diftributions and partitions of knowledge are not like feveral lines that meet in one angle, and fo touch but in a point; but are like branches of a tree, that meet in a ftem, which hath a dimenfion and quantity of entirenefs and continuance, before it come to difcontinue and break itfelf into arms and boughs: therefore it is good, before we enter into the former diftribution, to erect and conftitute one The Philofo- univerfal fcience, by the name of philofophia prima, phia Prima precedes all divifions. primitive or fummary philofophy, as the main and common way, before we come where the ways 
part and divide themfelves; which fcience whether I fhould report as deficient or no, I ftand doubtful. For I find a certain rhapfody of natural theology, and of divers parts of logic; and of that part of natural philofophy which concerneth the principles, and of that other part of natural philofophy which concerneth the foul or fpirit; all thefe ftrangely commixed and confufed; but being examined, it feemeth to me rather a depredation of other fciences, advanced and exalted unto fome height of terms, than anything folid or fubftantive of itfelf. Neverthelefs I cannot be ignorant of the diftinction which is current, that the fame things are handled but in feveral refpects. As for example, that logic confidereth of many things as they are in notion, and this philofophy as they are in nature; the one in appearance, the other in exiftence; but I find this difference better made than purfued. For if they had confidered quantity, fimilitude, diverfity, and the reft of thofe extern characters of things, as philofophers, and in nature, their inquiries muft of force have been of a far other kind than they are. For doth any of them, in handling quantity, fpeak of the force of union, how and how far it multiplieth virtue? Doth any give the reafon, why fome things in nature are fo common, and in fo great mafs, and others fo rare, and in fo fmall quantity? Doth any, in handling fimilitude and diverfity, affign the caufe why iron fhould not move to iron, which is more like, but move to the lode-ftone, which is lefs like? Why in all diverfities of things there hould be certain 
participles in nature, which are almolt ambiguous to which kind they fhould be referred? But there is a mere and deep filence touching the nature and operation of thofe common adjuncts of things, as in nature: and only a refuming and repeating of the force andufe of them in fpeech or argument. Therefore, becaufe in a writing of this nature, I avoid all fubtilty, my meaning touching this original or univerfal philofophy is thus, in a plain and grofs defcription by negative: That it be a receptacle for all fuch profitable obfervations and axioms as fall not within the compass of any of the special parts of philofophy or fciences, but are more common and of a bigher fage.

Now that there are many of that kind need not to be doubted. For example: is not the rule, $S i$ incqualibus aqualia addas, omnia erunt incequalia, an axiom as well of juftice as of the mathematics? ${ }^{59}$ and is there not a true coincidence between commutative and difributive juftice, and arithmetical and geometrical proportion? Is not that other rule, Qua in eodem tertio conveniunt, et inter Se conveniunt, a rule taken from the mathematics, but fo potent ir logic as all fyllogifms are built upon it? Is not the obfervation, Omnia mutantur, nil interit, ${ }^{60}$ a contemplation in philofophy thus, that the quantum of nature is eternal? in natural theology thus, that it requireth the fame Omnipo-

59 In Ellis and Spedding's ed. there is a note faying that this claufe and its fucceffor are tranfpofed in the original ed. This is not the cafe in the copy I have collated. And in one or two other notices of variation my copy did not bear out their remarks.

60 Plat. Theat. i. 152. Ovid, Met. xv. 165. 
tence to make fomewhat nothing, which at the firft made nothing fomewhat? according to the Scripture, Didici quod omnia opera, qua fecit Deus, perfeverent in perpetuum; non poffumus eis quicquam addere nec auferre. ${ }^{61}$ Is not the ground, which Machiavel wifely and largely difcourfeth concerning governments, that the way to eftablirh and preferve them, is to reduce them ad principia, a rule in religion and nature, as well as in civil adminiftration?62 Was not the Perfian magic a reduction or correfpondence of the principles and architectures of nature to the rules and policy of governments? Is not the precept of a mufician, to fall from a difcord or harh accord upon a concord or fweet accord, alike true in affection. Is not the trope of mufic, to avoid or flide from the clore or cadence, common with the trope of rhetoric of deceiving expectation? 63 Is not the delight of the quavering upon a ftop in mufic the fame with the playing of light upon the water?

Splendet tremulo fub lumine pontus. ${ }^{64}$

Are not the organs of the fenfes of one kind with the organs of reflection, the eye with a glars, the ear with a cave or ftrait determined and bounded? Neither are thefe only fimilitudes, as men of narrow obfervation may conceive them to be, but the fame footfteps of nature, treading or printing upon feveral fubjects or matters. This fcience, therefore, as I underftand it, I may juftly report as de-

61 Ecclus. xlii. 2 I.

62 Difcourfe on Livy, iii. I.

63 See Nov. Org. ii. 27. "Inftantiæ conformes."

64 Virg. $A$ n. vii. 9. 


\section{$134 A D V A N C E M E N T$ OF LEARNING.}

ficient : for I fee fometimes the profounder fort of wits in handling fome particular argument will now and then draw a bucket of water out of this well for their prefent ufe; but the fpring-head thereof feemeth to me not to have been vifited; being of fo excellent ufe, both for the difclofing of nature, and the abridgment of art.

De Aug. III. This fcience being therefore firft placed as a 2. common parent, like unto Berecynthia, which had fo much heavenly iffue,

Omnes Celicolas, omnes fupera alta tenentes, ${ }^{65}$

we may return to the former diftribution of the three philofophies, divine, natural, and buman.

(I.) Divine And as concerning divine philofophy or natural Philofophy, or Natural Theology. theology, it is that knowledge or rudiment of knowledge concerning God, which may be obtained by the contemplation of His creatures; which knowledge may be truly termed divine in refpect of the object, and natural in refpect of the light. The bounds of this knowledge are, that it fufficeth to convince atheifm, but not to inform religion : and therefore there was never miracle wrought by God to convert an atheift, becaufe the light of nature might have led him to confefs a God: but miracles have been wrought to convert idolaters and the fuperftitious, becaufe no light of nature extendeth to declare the will and true worfhip of God. For as all works do thow forth the power and kill of the workman, and not his image ; fo it is of the works of God, which do thow the omnipotency and wifdom of the Maker, but not His 65 Virg. $A E n$. vi. 787 . 
image : and therefore therein the heathen opinion differeth from the facred truth; for they fuppofed the world to be the image of God, and man to be an extract or compendious image of the world ; 66 but the Scriptures never vouchfafe to attribute to the world that honour, as to be the image of God, but only the work of His hands :67 neither do they fpeak of any other image of God, but man : wherefore by the contemplation of nature to induce and enforce the acknowledgment of God, and to demonftrate His power, providence, and goodnefs, is an excellent argument, and hath been excellently handled by divers.

But on the other fide, out of the contemplation of nature, or ground of human knowledge, to induce any verity or perfuafion concerning the points of faith, is in my judgment not fafe: Da fidei quae fidei funt. 68 For the heathens themfelves conclude as much in that excellent and divine fable of the golden chain: That men and gods were not able to draw Fupiter down to the earth; but contrariwife, Fupiter was able to draw them up to beaven. ${ }^{69}$ So as we ought not to attempt to draw down or fubmit the myfteries of God to our reafon; but contrariwife to raife and advance our reafon to the divine truth. So as in this part of knowledge, touching divine philofophy, I am fo far from noting any deficience, as I rather note an excefs : where-

66 Mєкро́кобноs-a favourite dogma with Paracelfus, who divided the body of man according to the cardinal points of the world. But Bacon is perhaps referring to the Platonifts in the firft part of the fentence.

${ }_{67}^{67}$ Ps. viii. 3. ${ }^{68}$ Luke xx. 25. $\quad{ }^{69}$ Hom. Il. viii. I9-22. 
unto I have digreffed becaufe of the extreme prejudice which both religion and philofophy have received and may receive, by being commixed together; as that which undoubtedly will make an heretical religion, and an imaginary and fabulous philofophy.

Otherwife it is of the nature of angels and fpirits, which is an appendix of theology both divine and natural, and is neither infcrutable nor interdicted; for although the Scripture faith, Let no man deceive you in fublime difcourfe touching the wor/hip of angels, preffing into that he knoweth not, $\xi^{0} c .{ }^{70}$ yet, notwithftanding, if you obferve well that precept, it may appear thereby that there be two things only forbidden, adoration of them, and opinion fantaftical of them, either to extol them farther than appertaineth to the degree of a creature, or to extol a man's knowledge of them farther than he hath ground. But the fober and grounded inquiry, which may arife out of the paffages of holy Scriptures, or out of the gradations of nature, is not reftrained. So of degenerate and revolted fpirits, the converfing with them or the employment of them is prohibited, much more any veneration towards them; but the contemplation or fcience of their nature, their power, their illufions, either by Scripture or reafon, is a part of fpiritual wifdom. For fo the apoftle faith, $W$ e are not ignorant of his fratagems. ${ }^{71}$ And it is no more unlawful to inquire the nature of evil fpirits, than to inquire the force of poifons in nature, or the 
nature of fin and vice in morality. But this part touching angels and fpirits I cannot note as deficient, for many have occupied themfelves in it;i I may rather challenge it, in many of the writers thereof, as fabulous and fantaftical.

Leaving therefore divine philofophy or natural theology, (not Divinity or infpired theology, which we referve for the laft of all, as the haven and fabbath of all man's contemplations) we will now De Augm. III. 3 .

(2.) Natural Philofoproceed to natural philofophy.

If then it be true that Democritus faid, That the truth of nature lieth bid in certain deep mines and caves, ${ }^{73}$ and if it be true likewife that the alchemifts do fo much inculcate, that Vulcan is a fecond nature, and imitateth that dexteroufly and compendioufly, which nature worketh by ambages and length of time, it were good to divide natural philofophy into the mine and the furnace: and to make two profeffions or occupations of natural philofophers, fome to be pioneers and fome fmiths; fome to dig, and fome to refine and hammer: and furely I do beft allow of a divifion of that kind, though in more familiar and fcholaftical terms; namely, that thefe be the two parts of natural philofophy, - the inquifition of caufes, and the production of effects; speculative, and operative; naturalfcience, and natural prudence. For as in civil matters there is a wifdom of difcourfe and a wifdom of direction;

72 The nature of Angels was a favourite fubject of fpeculation and difcuffion among the Schoolmen, whofe writings on it deferve Bacon's cenfure.

${ }^{73} \dot{\varepsilon} \nu \beta v \theta \tilde{u} \gamma a \dot{\rho} \rho \dot{\eta} a ́ \lambda \dot{\eta} \theta \varepsilon \iota \alpha$. Diog. Laert. ix. 72.-Whence our "Truth lies at the bottom of a Well." 


\section{I38 ADVANCEMENT OF LEARNING.}

fo is it in natural. And here I will make a requeft, that for the latter, or at leaft for a part thereof, I may revive and reintegrate the mifapplied and abufed name of natural magic ; ${ }^{74}$ which, in the true fenfe, is but natural wifdom, or natural prudence; taken according to the ancient acception, purged from vanity and fuperftition. Now although it be true, and I know it well, that there is an intercourfe between caufes and effects, fo as both thefe knowledges, fpeculative and operative, have a great connection between themfelves; yet becaufe all true and fruitful natural philofophy hath a double fcale or ladder, afcendent and defcendent : afcending from experiments to the invention of caufes, and defcending from caufes to the invention of new experiments; therefore I judge it moft requifite that thefe two parts be feverally confidered and handled.

DeAug.nin. Natural fcience or theory is divided into phyfique

4.

Natural

fcience is

Phyfical

and Meta.

phyfical :

the latter defined. and metaphyfique: wherein I defire it may be conceived that I ufe the word metaphyfique in a differing fenfe from that that is received: and in like manner, I doubt not but it will eafily appear to men of judgment, that in this and other particulars, wherefoever my conception and notion may differ from the ancient, yet I am ftudious to keep the ancient terms. For hoping well to deliver myfelf from miftaking, by the order and perficuous expreffing of that I do propound, I am otherwife zealous and affectionate to recede as little

${ }^{74}$ Cf. Nov. Org. ii. 9, and 5I, and De Augm. iii. 5, where he afferts for the term Magic its proper honours. 
from antiquity, either in terms or opinions, as may ftand with truth and the proficience of knowledge. And herein I cannot a little marvel at the philofopher Ariftotle, that did proceed in fuch a fpirit of difference and contradiction towards all antiquity: undertaking not only to frame new words of fcience at pleafure, but to confound and extinguifh all ancient wifdom: infomuch as he never nameth or mentioneth an ancient author or opinion, but to confute and reprove ${ }^{75}$ wherein for glory, and drawing followers and difciples, he took the right courfe. For certainly there cometh to pafs and hath place in human truth, that which was noted and pronounced in the higheft truth: $V$ eni in nomine Patris, nec recipitis me; fi quis venerit in nomine fuo eum recipietis. ${ }^{76}$ But in this divine aphorifm, (confidering to whom it was applied, namely to Antichrift, the higheft deceiver,) we may difcern well that the coming in a man's own name, without regard of antiquity or paternity, is no good fign of truth, although it be joined with the fortune and fuccefs of an Eum recipietis. But for this excellent perfon Ariftotle, I will think of him that he learned that humour of his fcholar, with whom, it feemeth, he did emulate; the one to conquer all opinions, as the other to conquer all nations; wherein neverthelefs, it may be, he may at fome men's hands that are of a bitter difpofition get a like title as his fcholar did:

$75 \mathrm{Cf}$. Norv. Org. i. 63.67 ; where he likens him to the Turks, whofe Sultans on afcending the throne murder all the feed royal. Ci. Ar. Eth.Nic. I. 6. i. where Ariftotle declares that it is fome-

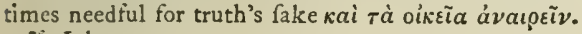

${ }^{70}$ John v. 43 . 


\section{I40 ADVANCEMENT OF LEARNING.}

Felix terrarum prado, non utile mundo

Editus exemplum, \&c.

So

Felix doctrinæ prædo. ${ }^{77}$

But to me, on the other fide, that do defire as much as lieth in my pen to ground a fociable intercourfe between antiquity and proficience, it feemeth beft to keep way with antiquity $u$ qque ad aras; and therefore to retain the ancient terms, though I fometimes alter the ufes and definitions, according to the moderate proceeding in civil government; where although there be fome alteration, yet that holdeth which Tacitus wifely noteth, Eadem Magiftratuum vocabula. ${ }^{78}$

And difin- To return therefore to the ufe and acception guifhed from the Pbilosopbia of the term Metaphyfique, as I do now underftand Prima. the word; it appeareth, by that which hath been already faid, that I intend philofophia prima; Summary Philofophy, and Metaphyfique, which heretofore have been confounded as one, to be two diftinct things. For the one I have made as a parent or common anceftor to all knowledge; and the other I have now brought in as a branch or defcendent of natural fcience. It appeareth likewife that I have affigned to Summary Philofophy the common principles and axioms which are promifcuous and indifferent to feveral fciences: I

Felix prædo jacet, terrarum vindice fato

Raptus. ....

Nam fibi libertas unquam fi redderet orbem,

Ludibrio fervatus erat, non utile mundo

Editus excmplum.

Lucan. Phars. x. 20.

78 Tac. Ann. i. 3. 
have affigned unto it likewife the inquiry touching the operation of the relative and adventive characters of effences, as quantity, fimilitude, diverfity, poffibility, and the reft: with this diftinction and provifion; that they be handled as they have efficacy in nature, and not logically. It appeareth likewife that Natural Theology, which heretofore hath been handled confufedly with Metaphyfique, I have inclofed and bounded by itfelf. It is therefore now a queftion what is left remaining for Metaphyfique; wherein I may without prejudice preferve thus much of the conceit of antiquity, that Phyfique fhould contemplate that which is inherent in matter, and therefore tranfitory; and Metaphyfique that which is abftracted and fixed. And again, that Phyfique fhould handle that which fuppofeth in nature only a being and moving; and Metaphyfique fhould handle that which fuppofeth further in nature a reafon, underftanding, and platform. But the difference, perficuoufly expreffed, is moft familiar and fenfible. For as we divided natural philofophy in general into the inquiry of caufes, and productions of effects : fo that part which concerneth the inquiry of caufes we do fubdivide according to the received and found divifion of caufes; the one part, which is Phyfique, inquireth and handleth the material and efficient caufes; and the other, which is Metaphyfique, handleth the formal and final caufes. 79

Phyfique, taking it according to the derivation, and not according to our idiom for medicine, is

${ }^{79}$ For thefe "four caufes," fee Arift. Poff. Anal. ii. Io. I. Cf. Mill's Logic, Bk. iii. Ch. 5 .

(i.) Phyfical; of the material and efficient caufes. 


\section{I42 ADVANCEMENT OF LEARNING.}

fituate in a middle term or diftance between $\mathrm{Na}$ tural Hiftory and Metaphyfique. For natural hiftory defcribeth the variety of things; phyfique, the caufes, but variable or refpective caufes; and metaphyfique, the fixed and conftant caufes.

Limus ut hic durefcit, et hæc ut cera liquefcit,
Uno eodemque igni :

Fire is the caufe of induration, but refpective to clay; fire is the caufe of colliquation, but refpective to wax; but fire is no conftant caufe either of induration or colliquation: fo then the phyfical caufes are but the efficient and the matter. Phyfique hath three parts; whereof two refpect nature united or collected, the third contemplateth nature diffufed or diftributed. Nature is collected either into one entire total, or elfe into the fame principles or feeds. So as the firft doctrine is touching the contexture or configuration of things, as de mundo, de univerfitate rerum. The fecond is the doctrine concerning the principles or originals of times. The third is the doctrine concerning all variety and particularity of things; whether it be of the differing fubftances, or their differing qualities and natures; whereof there needeth no enumeration, this part being but as a glors, or paraphrafe, that attendeth upon the text of natural hiftory. Of thefe three I cannot report any as deficient. In what truth or perfection they are handled, I make not now any judgment; but they are parts of knowledge not deferted by the labour of man.

80 Virg. Ecl. viii. 8o. 
For Metaphyfique, we have affigned unto it the inquiry of formal and final caufes; which affignation, as to the former of them, may feem to be (2.) Metaphyfical. (a.) Of fornugatory and void; becaufe of the received and inveterate opinion that the inquifition of man is not competent to find out effential Forms or true differences: of which opinion we will take this hold, that the invention of Forms is of all other parts of knowledge the worthieft to be fought, if it be poffible to be found. 81 As for the poffibility, they are ill difcoverers that think there is no land, when they can fee nothing but fea. But it is manifeft that Plato, in his opinion of Ideas, as one that had a wit of elevation fituate as upon a cliff, did defcry, that Forms were the true object of knozvledge ; ${ }^{82}$ but loft the real fruit of his opinion, by confidering of Forms as abfolutely abftracted from matter, and not confined and determined by matter; and fo turning his opinion upon theology, wherewith all his natural philofophy is infected. ${ }^{83}$ But if any man thall keep a continual watchful and fevere eye upon action, operation, and the ufe of knowledge, he may advife and take notice what are the Forms, the difclofures whereof are fruitful and important to the ftate of man. For as to the forms of fubftances, man only except, of whom it is faid, Formavit hominem de limo terre, et ppiravit in faciem ejus Jpiraculum vita, and not as of all

81 See Nov. Org. ii. 1. Datæ naturæ formam ... invenire, opus et intentio eft humanæ fcientiæ. The firft twenty chapters of Bk. ii. of the Nor. Org. are an attempt at expanfion of this faying.
${ }_{82}$ Plato, Rep. x. init.
${ }_{83}$ Nov. Org. i. $9^{6}$. 


\section{$144 A D V A N C E M E N T$ OF LEARNING.}

other creatures, Producant aqua, producat terra; ${ }^{64}$ the Forms of fubftances, I fay, as they are now by compounding and tranfplanting multiplied, are fo perplexed, as they are not to be inquired; no more than it were either poffible or to purpofe to feek in grofs the Forms of thofe founds which make words, which by compofition and tranfpofition of letters are infinite. But, on the other fide, to inquire the Form of thofe founds or voices which make fimple letters is eafily comprehenfible; and being known, induceth and manifefteth the Forms of all words, which confift and are compounded of them. In the fame manner to inquire the Form of a lion, of an oak, of gold; nay, of water, of air, is a vain purfuit : but to inquire the Forms of fenfe, of voluntary motion, of vegetation, of colours, of gravity and levity, of denfity, of tenuity, of heat, of cold, and all other natures and qualities, which, like an alphabet, are not many, and of which the effences, upheld by matter, of all creatures do confift ; to inquire, I fay, the true Forms of thefe, is that part of metaphyfique which we now define of. Not but that Phyfic doth make inquiry, and take confideration of the fame natures: but how? Only as to the material and efficient caufes of them, and not as to the Forms. For example; if the caufe of whitenefs in fnow or froth be inquired, and it be rendered thus, that the fubtile intermixture of air and water is the caufe, it is well rendered; but, neverthelefs, is this the form of whitenefs? No; but it is the efficient, which is ever 
but vebiculum forme. ${ }^{85}$ This part of Metaphyfique I do not find laboured and performed: whereat $I$ marvel not; becaufe I hold it not poffible to be invented by that courfe of invention which hath been ufed; in regard that men, which is the root of all error, have made too untimely a departure and too remote a recefs from particulars.

But the ufe of this part of Metaphyfique, which I report as deficient, is of the reft the moft excellent in two refpects: the one, becaufe it is the Good, as it abridges particulars. duty and virtue of all knowledge to abridge the infinity of individual experience, as much as the conception of truth will permit, and to remedy the complaint of vita brevis, ars longa ; 86 which is performed by uniting the notions and conceptions of fciences: for knowledges are as pyramids, whereof hiftory is the bafis. So of natural philofophy, the bafis is natural hiftory; the fage next the bafis is phyfique; the ftage next the vertical point is metaphyfique. As for the vertical point, opus quod operatur Deus à principio ufque ad finem, the fummary law of nature, we know not whether man's inquiry can attain unto it. But thefe three be the true 1tages of knowledge, and are to them that are depraved no better than the giant's hills:

Ter funt conati imponere Pelio Offam,

Scilicet atque Offæ frondolum involvere Olympum. ${ }^{88}$

But to thofe who refer all things to the glory of

${ }^{8 j}$ Nov. Org. ii. 3 , efficiens et materialis caufa (quæ caufæ fluxæ lunt, et nihil aliud quam velicula et caufæ formam deferentes in aliquibus.)

${ }_{85}$ Hippoc. Aph. i. $\quad{ }^{87}$ Eccles. iii. II. ${ }^{88}$ Georg. i. $281,282$. 


\section{I46 ADVANCEMENT OF LEARNING}

God, they are as the three acclamations, Sancte, fancte, fancte! holy in the defcription or dilatation of His works; holy in the connection or concatenation of them; and holy in the union of them in a perpetual and uniform law. And therefore the fpeculation was excellent in Parmenides and Plato, although but a fpeculation in them, that all things by fcale did afcend to unity. ${ }^{89}$ So then always that knowledge is worthieft which is charged with leaft multiplicity; which appeareth to be metaphyfique; as that which confidereth the fimple Forms or differences of things, which are few in number, and the degrees and co-ordinations whereof make all this variety.

And as it

The fecond refpect, which valueth and comgives liberty mendeth this part of metaphyfique, is that it doth
to man's powers. enfranchife the power of man unto the greateft liberty and poffibility of works and effects. For phyfique carrieth men in narrow and reftrained ways, fubject to many accidents of impediments, imitating the ordinary flexuous courfes of nature; but latre undique funt fapientibus vice: 90 to fapience, which was anciently defined to be rerum divinarum et bumanarum fientia, ${ }^{91}$ there is ever choice of means. For phyfical caufes give light to new invention in fimili materia; but whofoever knoweth any Form, knoweth the utmoft poffibility of fuperinducing that nature upon any variety of matter; and fo is lefs reftrained in operation, either to the

69 Plato, Parm. 165, I66.

90 Perhaps Prov. xv. 19, via juftorum abfque offendiculo.

91 Cic. de Off. i. 43. (154.) 
bafis of the matter, or the condition of the efficient; which kind of knowledge Salomon likewife, though in a more divine fort, elegantly defcribeth: non arctabuntur grefJus tui, et currens non babebis offendiculum.92 The ways of fapience are not much liable either to particularity or chance.

The fecond part of metaphyfique is the inquiry of final caufes, which I am moved to report not (b.) Of final caufes. as omitted, but as mifplaced; and yet if it were but a fault in order, I would not fpeak of it: for order is matter of illuftration, but pertaineth not to the fubftance of fciences. But this mifplacing hath caufed a deficience, or at leaft a great improficience in the fciences themfelves. For the handling of final caufes mixed with the reft in phyfical inquiries, hath intercepted the fevere and diligent inquiry of all real and phyfical caufes, and given men the occafion to ftay upon thefe fatisfactory and fpecious caufes, to the great arreft and prejudice of further difcovery. For this I find done not only by Plato, who ever anchoreth upon that fhore, but by Ariftotle, Galen, and others which do ufually likewife fall upon thefe flats of difcourfing caufes..$^{93}$ For to fay that the bairs of the eyelids are for a quickfet and fence about the fight; or that the firmness of the kins and bides of living creatures is to defend them from the extremities of beat or cold; or that the bones are for the columns or beams, whereupon the frames of the bodies of living creatures are

92 Prov. iv. I2.

93 Ariftot. Pbyf. ii. 8, 2, where he illuftrates by the teeth. Alfo Plat. Tim. iii. 70, and Galen, De Uju Partium. 
I48 ADVANCEMENT OF LEARNING.

built: or that the leaves of trees are for protecting of the fruit; or that the clouds are for watering of the earth; or that the folidnefs of the earth is for the fation and manfion of living creatures and the like, is well inquired and collected in metaphyfique, but in phyfique they are impertinent. Nay, they are indeed but remore, and hindrances to ftay and flug the fhip from further failing; and have brought this to pafs, that the fearch of the phyfical caufes hath been neglected, and paffed in filence. And therefore the natural philofophy of Democritus and fome others, (who did not fuppore a mind or reafon in the frame of things, but attributed the form thereof able to maintain itfelf to infinite effays or proofs of nature, which they term fortune) feemeth to me, as far as I can judge by the recital and fragments which remain unto us, in particularities of phyfical caufes, more real and better inquired than that of Ariftotle and Plato; whereof both intermingled final caufes, the one as a part of theology, and the other as a part of logic, which were the favourite ftudies refpectively of both thofe perfons. Not becaufe thofe final caufes are not true, and worthy to be inquired, being kept within their own province; but becaufe their excurfions into the limits of phyfical caufes hath bred a valtnefs and folitude in that track. For otherwife, keeping their precincts and borders, men are extremely deceived if they think there is an enmity or repugnancy at all between them. For the caufe rendered, that the bairs about the eye-lids are for the fafeguard of the fight, doth not 
impugn the caufe rendered, that pilojity is incident to orifices of moifture; mufcoli fontes, ${ }^{94}$ \&c. Nor the caufe rendered, that the firmness of bides is for the armour of the body againft exiremities of heat or cold, doth not impugn the caufe rendered, that contraction of pores is incident to the outwardeft parts, in regard of their adjacence to foreign or unlike bodies: and fo of the reft : both caufes being true and compatible, the one declaring an intention, the other a confequence only. Neither doth this call in queftion, or derogate from Divine Providence, but highly confirm and exalt it. For as in civil actions he is the greater and deeper politique, that can make other men the inftruments of his will and ends, and yet never acquaint them with his purpofe, fo as they fhall do it and yet not know what they do, than he that imparteth his meaning to thofe he employeth; fo is the wifdom of God more admirable, when nature intendeth one thing, and Providence draweth forth another, than if $\mathrm{He}$ communicated to particular creatures and motions the characters and impreffions of His Providence. And thus much for metaphyfique : the latter part whereof I allow as extant, but wifh it confined to his proper place.

Neverthelefs there remaineth yet another part of Natural Philofophy, which is commonly made a principal part, and holdeth rank with Phyfique fpecial and Metaphyfique, which is Mathematique; but I think it more agreeable to the

De Augm. III. 6 . Mathematics may be ranked under Metaphyfics. nature of things and to the light of order to 


\section{I50 ADVANCEMENT OF LEARNING.}

place it as a branch of Metaphyfique: for the fubject of it being quantity, (not quantity indefinite, which is but a relative, and belongeth to philofophia prima, as hath been faid, but quantity determined or proportionable), it appeareth to be one of the effential Forms of things; as that that is caufative in nature of a number of effects ; infomuch as we fee, in the fchools both of Democritus and of Pythagoras, 95 that the one did afcribe figure to the firft feeds of things, and the other did fuppofe numbers to be the principles and originals of things: and it is true alfo that of all other Forms, as we underftand Forms, it is the moft abftracted and feparable from matter, and therefore moft proper to Metaphyfique; which hath likewife been the caure why it hath been better laboured and inquired than any of the other Forms, which are more immerfed in matter.

For it being the nature of the mind of man, to the extreme prejudice of knowledge, to delight in the fpacious liberty of generalities, as in a champain region, and not in the inclofures of particularity; the Mathematics of all other knowledge were the goodlieft fields to fatisfy that appetite. But for the placing of this fcience, it is not much material: only we have endeavoured in thefe our partitions to obferve a kind of perfpective, that one part may caft light upon another.

This branch

The Mathematics are either pure or mixed. To

is,

(a.) Pure. the Pure Mathematics are thofe fciences belonging

95 For thefe opinions of Democritus and the Pythagoreans, fee Ariftot. De Anima, i. 2, Met. i. 4, 5. 
which handle quantity determinate, merely fevered from any axioms of natural philofophy; and thefe are two, Geometry and Arithmetic; the one handling quantity continued, and the other diffevered.

Mixed hath for fubject fome axioms or parts of natural philofophy, and confidereth quantity determined, as it is auxiliary and incident unto them. For many parts of nature can neither be invented with fufficient fubtilty, nor demonftrated with fufficient perfpicuity, nor accommodated unto ufe with fufficient dexterity, without the aid and intervening of the mathematics; of which fort are perspective, mufic, aftronomy, cofmograpby, architecture, enginery, and divers others.

In the Mathematics I can report no deficience, except it be that men do not fufficiently underftand the excellent ufe of the Pure Mathematics, in that they do remedy and cure many defects in the wit and faculties intellectual. For if the wit be too dull, they tharpen it; if too wandering, they fix it; if too inherent in the fenfe, they abstract it. So that as tennis is a game of no ufe in itfelf, but of great ufe in refpect it maketh a quick eye and a body ready to put itfelf into all poftures; fo in the Mathematics, that ufe which is collateral and intervenient is no lefs worthy than that which is principal and intended. And as for the Mixed Mathematics, I may only make this prediction, that there cannot fail to be more kinds of them, as nature grows further diflofed. Thus much of Natural Science, or the part of nature fpeculative. For Natural Prudence, or the part operative of Prudence. 


\section{$152 A D V A N C E M E N T$ OF LEARNING.}

Natural Philofophy, we will divide it into three parts, experimental, philofophical, and magical; which three parts active have a correfpondence and analogy with the three parts fpeculative, natural hiftory, phyfique, and metaphyfique: for

(1.) Experi- many operations have been invented, fometimes mental. by a cafual incidence and occurrence, fometimes by a purpofed experiment: and of thofe which have been found by an intentional experiment, fome - have been found out by varying or extending the fame experiment, fome by transferring and compounding divers experiments the one into the other, which kind of invention an empiric may manage.

De Augm.

iji. 5 .

(2.) Philotophical.

Again, by the knowledge of phyfical caufes there cannot fail to follow many indications and defignations of new particulars, if men in their fpeculation will keep one eye upon ufe and practice. But thefe are but coaftings along the fhore, Premendo littus iniquum: 96 for it feemeth to me there can hardly be difcovered any radical or fundamental alterations and innovations in nature, either by the fortune and effays of experiments, or by the light and direction of phyfical caufes.

(3.) Ma- If therefore we have reported Metaphyfique defigical. cient, it muft follow that we do the like of natural Magic, which hath relation thereunto. For as for the Natural Magic whereof now there is mention in books, containing certain credulous and fuperftitious conceits and obfervations of fympathies and antipathies, and hidden properties, and fome 
frivolous experiments, ftrange rather by difguifement than in themfelves; it is as far differing in truth of nature from fuch a knowledge as we require, as the ftory of King Arthur of Britain, or Hugh of Bordeaux, differs from Cæarar's Commentaries in truth of ftory. For it is manifeft that Cæar did greater things de vero than thofe imaginary heroes were feigned to do; but he did them not in that fabulous manner. Of this kind of learning the fable of Ixion 97 was a figure, who defigned to enjoy Juno, the goddefs of power; and inftead of her had copulation with a cloud, of which mixture were begotten centaurs and chimeras. So whofoever thall entertain high and vaporous imaginations, inftead of a laborious and fober inquiry of truth, thall beget hopes and beliefs of Atrange and impoffible hapes.

And therefore we may note in thefe fciences which hold fo much of imagination and belief, as this degenerate Natural Magic, Alchemy, Aftrology, and the like, that in their propofitions the defcription of the mean is ever more monftrous than the pretence or end. For it is a thing more probable, that he that knoweth well the natures of weight, of colour, of pliant and fragile, in refpect of the hammer, of volatile and fixed in refpect of the fire and the reft, may fuperinduce upon fome metal the nature and Form of gold by fuch mechanique as belongeth to the production of the natures afore rehearfed, than that fome grains of the medicine projected fhould in a few moments of

97 Pind. Pytb. ii. 2 . 


\section{I54 ADVANCEMENT OF LEARNING.}

time turn a fea of quickfilver or other material into gold: fo it is more probable that he that knoweth the nature of arefaction, the nature of affimilation of nourifhment to the thing nourithed, the manner of increafe and clearing of fpirits, the manner of the depredations which fpirits make upon the humours and folid parts, hall by ambages of diets, bathings, anointings, medicines, motions, and the like, prolong life, or reftore fome degree of youth or vivacity, than that it can be done with the ufe of a few drops or fcruples of a liquor or receipt. To conclude, therefore, the true Natural Magic, which is that great liberty and latitude of operation which dependeth upon the knowledge of Forms, I may report deficient, as the relative thereof is.

To which part, if we be ferious, and incline not to vanities and plaufible difcourfe, befides the deriving and deducing the operations themfelves from Metaphyfique, there are pertinent two points of much purpofe, the one by way of preparation, the other by way of caution: the firft is, that there be made a kalendar, refembling an inventory of the eftate of man, containing all the inventions, being the works or fruits of nature or art, which are now extant, and whereof man is already poffeffed; out of which doth naturally refult a note, what things are yet held impoffible, or not invented: which kalendar will be the more artificial and ferviceable, if to every reputed impoffibility you add what thing is extant which cometh the neareft in degree to that impoffibility; to the end that by thefe optatives and 
potentials man's inquiry may be more awake in deducing direction of works from the fpeculation of caufes: and fecondly, that thofe experiments be not only efteemed which have an immediate and prefent ufe, but thofe principally which are of moft univerfal confequence for invention of other experiments, and thofe which give moft light to the invention of caures; for the invention of the mariner's needle, which giveth the direction, is of no lefs benefit for navigation than the invention of the fails which give the motion.

Thus have I paffed through Natural Philofophy, and the deficiencies thereof; wherein if I have Conclufion of this part. differed from the ancient and received doctrines, and thereby fhall move contradiction; for my part, as I affect not to difient, fo I purpofe not to contend. If it be truth,

Non canimus furdis, refpondent omnia fylvæ. ${ }^{98}$

The voice of nature will confent, whether the voice of man do or no. And as Aiexander Borgia was wont to fay of the expedition of the French for Naples, that they came with chalk in their hands to mark up their lodgings, and not with weapons to fight; fo I like better that entry of truth which cometh peaceably, with chalk to mark up thofe minds which are capable to lodge and harbour it, than that which cometh with pugnacity and contention. 99

But there remaineth a divifion of natural philo- De Augm.

98 Virg. Ecl. x. 8. III. 4 .

99 Nov. Org. i. 35. This faying of Alexander VI. was called forth by the expedition of Charles VIII. which over-ran Italy in about five months, A.D. 1494. 


\section{I56 ADVANCEMENT OF LEARNING.}

fophy according to the report of the inquiry, and nothing concerning the matter or fubject; and that is pofitive and confiderative; when the inquiry reporteth either an affertion or a doubt. Thefe doubts or non liquets are of two forts, particular and total. For the firft, we fee a good example thereof in Ariftotle's Problems, which deferved to have had a better continuance; but fo neverthelefs as there is one point whereof warning is to be given and taken. The regiftering of doubts hath two excellent ufes: the one, that it faveth philofophy from errors and falfehoods; when that which is not fully appearing is not collected into affertion, whereby error might draw error, but referved in doubt: the other, that the entry of doubts are as fo many fuckers or fponges to draw ufe of knowledge; infomuch as that which, if doubts had not preceded, a man thould never have advifed, but paffed it over without note, by the fuggeftion and folicitation of doubts, is made to be attended and applied. But both thefe commodities do fcarcely countervail an inconvenience which will intrude itfelf, if it be not debarred; which is, that when a doubt is once received, men labour rather how to keep it a doubt ftill, than how to folve it; and accordingly bend their wits. Of this we fee the familiar example in lawyers and fcholars, both which, if they have once admitted a doubt, it goeth ever after authorized for a doubt. But that ufe of wit and knowledge is to be allowed, which laboureth to make doubtful things certain, and not thofe which labour to make certain things 
doubtful. Therefore thefe kalendars of doubts I commend as excellent things; fo that there be this caution ufed, that when they be thoroughly fifted and brought to refolution, they be from thenceforth omitted, decarded, and not continued to cherifh and encourage men in doubting. To which kalendar of doubts or problems, I advife be annexed another kalendar, as much or more material, which is a $\mathrm{Kalendar}$ of popular errors: I mean chiefly in natural hiftory, fuch as pals in fpeech and conceit, and are neverthelefs apparently detected and convicted of untruth ; that man's knowledge be not weakened nor embafed by fuch drofs and vanity.

As for the doubts or non liquets general, or in total, I underftand thofe differences of opinions touching the principles of nature, and the fundamental points of the fame, which have caufed the diverfity of fects, fchools, and philofophies, as that of Empedocles, Pythagoras, Democritus, Parmenides, and the reft. For although Ariftotle, as though he had been of the race of the Ottomans, thought he could not reign except the firft thing he did he killed all his brethren ; ${ }^{1}$ yet to thofe that feek Truth and not magiftrality, it cannot but feem a matter of great profit, to fee before them the feveral opinions touching the foundations of nature; not for any exact truth that can be ex-

1 See Ellis' note on De Augm. iii. 4, where he fuggefts, moft probably, that Bacon is alluding to the acts of Mahomet III. who, on becoming Sultan, in A. D. I 595, put to death nineteen brothers, and ten or twelve women, fuppoled to be with child by his father. $\mathrm{He}$ adds that the practice was eftablifhed as a fundamental State Law by Mahomet II. 


\section{ADVANCEMENT OF LEARNING.}

pected in thofe theories; for as the fame phenomena in aftronomy are fatisfied by the received aftronomy of the diurnal motion, and the proper motions of the planets, with their eccentrics and epicycles, and likewife by the theory of Copernicus, $\stackrel{2}{ }$ who fuppored the earth to move, (and the calculations are indifferently agreeable to both, ) fo the ordinary face and view of experience is many times fatisfied by feveral theories and philofophies; whereas to find the real truth requireth another manner of feverity and attention. For as Ariftotle faith, ${ }^{3}$ that children at the firft will call every woman mother, but afterward they come to diftinguifh according to truth, fo experience, if it be in childhood, will call every philofophy mother, but when it cometh to ripenefs, it will difcern the true mother. So as in the mean time it is good to fee the feveral gloffes and opinions upon nature, whereof, it may be, every one in fome one point hath feen clearer than his fellows: therefore I wifh fome collection to be made, painfully and underftandingly, de antiquis pbilosopbiis, out of all the poffible light which remaineth to us of them: which kind of work I find deficient. But here I muft give warning, that it be done diftinctly and feverally; the philofophies of every one through-

2 Nov. Org. i. 45. where he calls thefe " eccentrics and epicycles," linea Spirales et dracones. Bacon was ignorant of, and incurious about Mathematics and Aftronomy at this time; and fhows no good will towards Galileo and the "Copernican theory."

3 Ariftot. Pbys. i. 1.

4 Edd. $1605,163 \hat{3}$, read feverely; but the Latin has diffincte, which feems to require fever ally. 
out by themfelves; and not by titles packed and fagotted up together, as hath been done by Plutarch. For it is the harmony of a philofophy in itfelf which giveth it light and credence; whereas if it be fingled and broken, it will feem more foreign and diffonant. For as when I read in Tacitus the actions of Nero, or Claudius, with circumftances of times, inducements, and occafions, I find them not fo ftrange; but when I read them in Suetonius Tranquillus, gathered into titles and bundles, and not in order of time, they feem more monftrous and incredible: fo is it of any philofophy reported entire, and difmembered by articles. Neither do I exclude opinions of latter times to be likewife reprefented in this kalendar of fects of philofophy, as that of Theophraftus Paracelfus, ${ }^{5}$ eloquently reduced into a harmony by the pen of Severinus the Dane : ${ }^{6}$ and that of Telefius ${ }^{7}$ and his fcholar Donius, being as a paftoral philofophy, full of fenfe, but of no great depth; and that of Fracaftorius, ${ }^{8}$ who, though he pretended not to make any new philofophy, yet did ufe the abfolutenefs of his own fenfe upon the old; and that of Gilbertus our countryman, ${ }^{9}$ who revived, with

5 Paracelfus (von Hohenheim), enthufiaft and alchemift, born A. D. 1493, died A. D. 1541. He, though in a purpofely obfcure way, did much fervice to experimental philofophy.

6 Severinus, a Danifh phyfician, died in 1602.

7 Telefius, born in 1509 at Colenza; who, as Bacon adds in the Latin, revived the philofophy of Parmenides.

8 Fracaftorius, born in 1483 at Verona; a man of greateft worth, dilintereftednefs, and capacity; whether as Poet, Philofopher, Phyfician, Aftronomer, or Mathematician. But of courfe Bacon has no good word for him.

- Gilbertus, Court Phyfician to Elizabeth and James I, a great 


\section{ADVANCEMENT OF LEARNING.}

fome alterations and demonftrations, the opinions of Xenophanes: and any other worthy to be admitted.

Thus have we now dealt with two of the three beams of man's knowledge ; that is, radius directus, which is referred to nature; radius refractus, which is referred to God, and cannot report truly becaufe of the inequality of the medium. There refteth radius reflexus, whereby man beholdeth and contemplateth himfelf.

(3.) De We come therefore now to that knowledge Augm.Iv. I. whereunto the ancient oracle directeth us, which Philofophy. is the knowledge of ourfelves $;^{10}$ which deferveth the more accurate handling, by how much it toucheth us more nearly. This knowledge, as it is the end and term of natural philofophy in the intention of man, fo notwithftanding it is but a portion of natural philofophy in the continent of nature: and generally let this be a rule, that all partitions of knowledges be accepted rather for lines and veins than for fections and feparations; and that the continuance and entirenefs of knowledge be preferved. For the contrary hereof hath made particular fciences to become barren, fhallow, and erroneous, while they have not been nourifhed and maintained from the common fountain. So we fee Cicero the orator complained of Socrates and his fchool, that he was the firft that feparated philofophy and rhetoric ;11 whereupon rhetoric

experimentaliff and difcoverer in Magnetifm. Bacon feems to have regarded him with efpecial ill-will.

10 Plat. Alcib. Pr. ii. 124. " Cic. de Orat. iii. 16, 17. 
became an empty and verbal art. So we may fee that the opinion of Copernicus touching the rotation of the earth, which aftronomy itfelf cannot correct, becaufe it is not repugnant to any of the phænomena, yet natural philofophy may correct. So we fee alfo that the fcience of medicine, if it be deftituted and forfaken by natural philofophy, it is not much better than an empirical practice. With this refervation therefore we proceed to human philofophy or humanity, which hath two parts : the one confidereth man fegregate or difributively; the other congregate or in fociety. So as human philofophy is either fimple and particular, or conjugate and civil.

Humanity particular confifteth of the fame parts whereof man confifteth; that is, of knowledges which refpect the body, and of knowledges which refpect the mind. But before we diftribute fo far, it is good to conftitute. For I do take the confideration in general and at large of human nature to be fit to be emancipate and made a knowledge by itfelf: not fo much in regard of thofe delightful and elegant difcourfes which have been made of the dignity of man, of his miferies, of his ftate and life, and the like adjuncts of his common and undivided nature; but chiefly in regard of the knowledge concerning the fympathies and concordances between the mind and body, which being mixed cannot be properly affigned to the fciences of either.

This knowledge hath two branches: for as all This in two leagues and amities confift of mutual intelligence parts. 


\section{$162 A D V A N C E M E N T$ OF LEARNING.}

and mutual offices, fo this league of mind and body hath thefe two parts; how the one difclofeth the other, and how the one worketh upon the

(a.) Difca- other; difcovery and impreffion. The former of very.

thefe hath begotten two arts, both of prediction or prenotion; whereof the one is honoured with the inquiry of Ariftotle, and the other of Hippocrates. ${ }^{12}$ And although they have of later time been ufed to be coupled with fuperftitious and fantaftical arts, yet being purged and reftored to their true ftate, they have both of them a folid ground in nature, and a profitable ufe in life. The firft is pbyjiognomy, which difcovereth the difpofition of the mind by the lineaments of the body: the fecond is the expofition of natural dreams, which difcovereth the ftate of the body by the imaginations of the mind. In the former of thefe I note a deficience. For Ariftotle hath very ingeniouny and diligently handled the factures of the body, but not the geftures of the body, which are no lefs comprehenfible by art, and of greater ufe and advantage. ${ }^{13}$ For the lineaments of the body do difclofe the difpofition and inclination of the mind in general; but the motions of the countenance and parts do not only fo, but do further difclofe the prefent humour and ftate of the mind and will. For as your majefty faith moft aptly and elegantly, As the tongue jpeaketh to the ear fo the gefture Jpeaketh to

12 In his Pranotiones.

13 In the treatifes on the Hiftory and Parts of Animals. The fubject of Gefture may be faid to come under the fhort treatifes on the External Phenomena of the Animal Kingdom: and in that on the Motion of Animals. 
the eye. ${ }^{14}$ And therefore a number of fubtle perfons, whofe eyes do dwell upon the faces and fafhions of men, do well know the advantage of this obfervation, as being moft part of their ability ; neither can it be denied, but that it is a great difcovery of diffmulations, and a great direction in bufinefs.

The latter branch, touching impreffion, hath not ( $\beta$.) imbeen collected into art, but hath been handled difpreffion. perfedly; and it hath the fame relation or antiArophe that the former hath. For the confideration is double: either bow, and bow far the bumours and affects of the body do alter or work upon the mind; or again, bow and bow far the paffions or apprebenfions of the mind do alter or work upon the body. The former of thefe hath been inquired and confidered as a part and appendix of medicine, but much more as a part of religion or fuperfition. For the phyfician prefcribeth cures of the mind in phrenfies and melancholy paffions; and pretendeth alfo to exhibit medicines to exhilarate the mind, to confirm the courage, to clarify the wits, to corroborate the memory, and the like: but the fcruples and fuperftitions of diet and other regimen of the body in the fect of the Pythagoreans, in the herefy of the Manicheans, and in the law of Mahomet, do exceed. So likewife the ordinances in the ceremonial law, interdicting the eating of the blood and the fat, diftinguifhing between beafts clean and unclean for meat, are many and ftrict. Nay

14 Spedding gives Bafilikon Dron, Bk. iii. as the place whence this quotation comes. Cr. Horace, A.P. $180,18 \mathrm{r}$. 
the faith itfelf being clear and ferene from all clouds of ceremony, yet retaineth the ufe of faftings, abftinences, and other macerations and humiliations of the body, as things real, and not figurative. The root and life of all which prefcripts is, befides the ceremony, the confideration of that dependency which the affections of the mind are fubmitted unto upon the ftate and difpofition of the body. And if any man of weak judgment do conceive that this fuffering of the mind from the body doth either queftion the immortality, or derogate from the fovereignty of the foul, he may be taught in eafy inftances, that the infant in the mother's womb is compatible with the mother and yet feparable $;^{15}$ and the moft abfolute monarch is fometimes led by his fervants and yet without fubjection. As for the reciprocal knowledge, which is the operation of the conceits and paffions of the mind upon the body, we fee all wife phyficians, in the prefcriptions of their regiments to their patients, do ever confider accidentia animi as of great force to further or hinder remedies or recoveries : and more efpecially it is an inquiry of great depth and worth concerning imagination, how and how far it altereth the body proper of the imaginant. For although it hath a manifeft power to hurt, it followeth not it hath the fame degree of power to help; no more than a man can conclude, that becaufe there be peftilent airs able fuddenly to kill a man in health, therefore there thould be fovereign

Is Qui fimul cum matris affectibus compatitur, et tamen e corpore matris fuo tempore excluditur. De Augm. 
airs able fuddenly to cure a man in ficknefs. But the inquifition of this part is of great ufe, though it needeth, as Socrates faid, a Delian diver, ${ }^{16}$ being difficult and profound. But unto all this knowledge de communi vinculo, of the concordances between the mind and the body, that part of inquiry is moft neceffary, which confidereth of the feats and domiciles which the feveral faculties of the mind do take and occupate in the organs of the body; which knowledge hath been attempted, and is controverted, and deferveth to be much better inquired. For the opinion of Plato, ${ }^{17}$ who placed the underftanding in the brain, animofity (which he did unfitly call anger, having a greater mixture with pride) in the beart, and concupifcence or fenfuality in the liver, deferveth not to be defpifed; but much lefs to be allowed. So then we have conftituted, as in our own wifh and advice, the inquiry touching human nature entire, as a juft portion of knowledge to be handled apart.

The knowledge that concerneth man's body is divided as the good of man's body is divided, unto which it referreth. The good of man's body is of four kinds, Health, Beauty, Strength, and Pleafure:

16 Diog. Laert. ii. 22. Socrates fpeaks of a work of Heraclitus which Euripides had lent him: "Delio quopiam natatore in. diget."

17 Plat. Tim. 69, 70, (Steph.) In the bead, ro Oriov: then below the ithmus of the neck, the mortal part of man; firft $\tau$ o

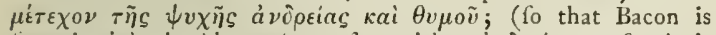
icarcely right in his centure; for neither ávipeia nor $\theta v \mu$ òc is anger) then the diapbragm to divide the parts; then in the heart

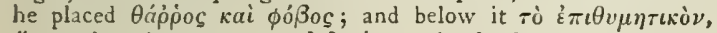

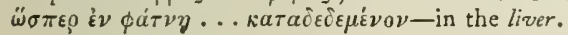

De Aug. Iv. 2.

(a.) Of $\mathrm{Hu}$ man Philofophy regarding the Body. 


\section{$166 A D V A N C E M E N T$ OF LEARNING.}

fo the knowledges are Medicine, or art of Cure; art of Decoration, which is called Cofmetic; art of Activity, which is called Athletic; and art Voluptuary, which Tacitus truly calleth eruditus luxus. ${ }^{18}$ This fubject of man's body is of all other things in nature moft fufceptible of remedy; but then that remedy is moft fufceptible of error. For the fame fubtility of the fubject doth caufe large poffibility and eafy failing; and therefore the inquiry ought to be the more exact.

(a.) Medi- To fpeak therefore of Medicine, and to refume cine. that we have faid, afcending a little higher: the ancient opinion that man was microcofmus, an abAtract or model of the world, hath been fantaftically ftrained by Paracelfus ${ }^{19}$ and the alchemifts, as if there were to be found in man's body certain correfpondences and parallels, which hould have refpect to all varieties of things, as ftars, planets, minerals, which are extant in the great world. But thus much is evidently true, that of all fubfances which nature hath produced, man's body is the moft extremely compounded. For we fee herbs and plants are nourifhed by earth and water; bealts for the moft part by herbs and fruits; man by the fleth of beaits, birds, fithes, herbs, grains, fruits, water, and the manifold alterations, dreffings, and preparations of the feveral bodies, before they come to be his food and aliment. Add hereunto, that beafts have a more fimple order of life, and lefs change of affections to work upon their

18 Tac. Ann. xvi. 18.

19 Sce Ellis and Spedding's note to Nors. Org. ii. $4^{8}$. (p. 339.) 
bodies: whereas man in his manfion, fleep, exercife, paffions, hath infinite variations : and it cannot be denied but that the Body of man of all other things is of the moft compounded mafs. The Soul on the other fide is the fimpleft of fubftances, as is well exprefled :

\section{Purumque reliquit}

Ethereum fenfum atque aurai fimplicis ignem. ${ }^{20}$

So that it is no marvel though the foul fo placed enjoy no reft, if that principle be true, that Motus rerum eft rapidus extra locum, placidus in loco. But to the purpofe: this variable compofition of man's body hath made it as an inftrument eafy to diftemper; and therefore the poets did well to conjoin Mufic and Medicine in Apollo, ${ }^{21}$ becaufe the office of Medicine is but to tune this curious harp of man's body and to reduce it to harmony. So then the fubject being fo variable, hath made the art by confequence more conjectural; and the art being conjectural hath made fo much the more place to be left for impofture. For almoft all other arts and fciences are judged by acts, or mafter-pieces, as I may term them, and not by the fucceffes and events. The lawyer is judged by the virtue of his pleading, and not by the iffue of the caufe; the mafter of the fhip is judged by the directing his courfe aright, and not by the fortune of the voyage; but the phyfician, and perhaps the politique, hath no particular acts demonftrative of his ability, but is judged moft by the event ; which is ever but as it is taken: for who can tell, if a

20 Virg. $\mathbb{E n}$, vi. 747.

21 Ovid, Metam. i. 52 I. 


\section{ADVANCEMENT OF LEARNING.}

patient die or recover, or if a ftate be preferved or ruined, whether it be art or accident? And therefore many times the impoftor is prized, and the man of virtue taxed. Nay, we fee the weaknefs and credulity of men is fuch, as they will often prefer a mountebank ${ }^{22}$ or witch before a learned phyfician. And therefore the poets were clearfighted in difcerning this extreme folly, when they made Æfculapius and Circe brother and fifter, both children of the fun, as in the verfes,

Ipfe repertorem medicinæ talis et artis

Fulmine Phabigenam Stygias detrufit ad undas : ${ }^{23}$

And again,

Dives inaccefios ubi Solis filia lucos, \&c. ${ }^{24}$

For in all times, in the opinion of the multitude, witches and old women and impoftors have had a competition with phyficians. And what followeth? Even this, that phyficians fay to themfelves as Salomon exprefleth it upon an higher occafion; If it befall to me as befalleth to the fools, why fhould I labour to be more wife? ${ }^{25}$ And therefore I cannot much blame phyficians, that they ufe commonly to intend fome other art or practice, which they fancy more than their profeflion. For you Shall have of them antiquaries, poets, humanifts, ftatefmen, merchants, divines, and in every of thefe better feen than in their profeffion; and no doubt upon this ground, that they find that mediocrity and excellency in their art maketh no

${ }^{22}$ Montabank -in the old editions-from montambanco, a quackdoctor. Holland, in his Plutarch, renders the word mount-bank. The word was confined in meaning to a quack in Bacon's day.

${ }^{23}$ Virg. $A E n$, vii. $772 . \quad{ }^{24}$ Ibid. vii. I1. ${ }^{25}$ Eccles. ii. I5. 
difference in profit or reputation towards their fortune ; for the weaknefs of patients, and fweetnefs of life, and nature of hope, maketh men depend upon phyficians with all their defects. But neverthelefs, thefe things which we have fpoken of, are courfes begotten between a little occafion, and a great deal of noth and default; for if we will excite and awake our obfervation, we fhall fee in familiar inftances what a predominant faculty the fubtilty of spirit hath over the variety of matter or form: nothing more variable than faces and countenances: yet men can bear in memory the infinite diftinctions of them; nay, a painter with a few thells of colours, and the benefit of his eye and habit of his imagination, can imitate them all that ever have been, are, or may be, if they were brought before him: nothing more variable than voices; yet men can likewife difcern them perfonally: nay, you thall have a buffoon or pantomimus, ${ }^{26}$ who will exprefs as many as he pleafeth. Nothing more variable than the differing founds of words; yet men have found the way to reduce them to a few fimple letters. So that it is not the infufficiency or incapacity of man's mind, but it is the remote ftanding or placing thereof, that breedeth thefe mazes and incomprehenfions: for as the fenfe afar off is full of miftaking, but is exact at hand, fo is it of the underftanding; the remedy whereof is, not to quicken or ftrengthen the organ,

26 Buffon, or pantomimus, in the originai; howing that the words were newly imported into the Englifh tongue. The pantomime was then a perfon, not a play. 
but to go nearer to the object; and therefore there is no doubt but if the phyficians will learn and ufe the true approaches and avenues of nature, they may affume as much as the poet faith :

Et quoniam variant morbi, variabimus artes;

Mille mali fpecies, mille falutis erunt. ${ }^{27}$

Which that they thould do, the nobleners of their art doth deferve; well thadowed by the poets, in that they made $Æ f$ culapius to be the fon of the fun, the one being the fountain of life, the other as the fecond fream : but infinitely more honoured by the example of our Saviour, who made the body of man the object of His miracles, as the foul was the object of His doctrine. For we read not that ever $\mathrm{He}$ vouchfafed to do any miracle about honour or money, except that one for giving tribute to Cæa far ${ }^{28}$ but only about the preferving, fuftaining, and healing the body of man.

Medicine is a fcience which hath been, as we faid, more profeffed than laboured, and yet more laboured than advanced; the labour having been, in my judgment, rather in circle than in progreffion. For I find much iteration, but fmall addition. It confidereth caufes of difeafes, with the occafions or impulfions; the difeafes themfelves, with the accidents; and the cures, with the prefervations. The deficiencies which I think good to note, being a few of many, and thofe fuch as are of a more open and manifeft nature, I will enumerate, and not place.

Deficient in The firft is the difcontinuance of the ancient its Patholo- and ferious diligence of Hippocrates, ${ }^{29}$ which ufed $8 \%$.

$$
\begin{aligned}
& 27 \text { Ovid, } R \text {. A. } 525 . \quad{ }^{28} \text { Matt. xvii. } 27 . \\
& { }^{20} \text { Hippocr. De Epidemiis. }
\end{aligned}
$$


to fet down a narrative of the fpecial cafes of his patients, and how they proceeded, and how they Narrationes were judged by recovery or death. Therefore having an example proper in the father of the art, I thall not need to allege an example foreign, of the wifdom of the lawyers, who are careful to report new cafes and decifions for the direction of future judgments. This continuance of medicinal biftory I find deficient; which I underftand neither to be fo infinite as to extend to every common cafe, nor fo referved as to admit none but wonders: for many things are new in the manner, which are not new in the kind; and if men will intend to obferve, they thall find much worthy to obferve.

In the inquiry which is made by Anatomy, I find much deficience : for they inquire of the parts, And in Anatomy. and their fubflances, figures, and collocations; but comparata. they inquire not of the diverfities of the parts, the fecrecies of the pafjages, and the feats or neflings of the bumours, nor much of the footfleps and impreffions of difeafes: the reafon of which omiffion I fuppofe to be, becaufe the firit inquiry may be fatisfied in the view of one or a few anatomies: but the latter, being comparative and cafual, muft arife from the view of many. And as to the diverfity of parts, there is no doubt but the facture or framing of the inward parts is as full of difference as the outward, and in that is the caufe continent of many difeafes; which not being obferved, they quarrel many times with humours, which are not in fault; the fault being in the very frame and 


\section{$172 A D V A N C E M E N T$ OF LEARNING.}

mechanic of the part, which cannot be removed by medicine alterative, but muft be accommodate and palliate by diets and medicines familiar. As for the paffages and pores, it is true which was anciently noted, that the more fubtle of them appear not in anatomies, becaufe they are thut and latent in dead bodies, though they be open and manifeft in live: which being fuppofed, though the inhumanity of anatomia vivorum was by Celfus juftly reproved; ${ }^{30}$ yet in regard of the great ufe of this obfervation, the inquiry needed not by him fo nightly to have been relinquined altogether, or referred to the cafual practices of furgery; but mought have been well diverted upon the diffection of beafts alive, which notwithftanding the diffimilitude of their parts, may fufficiently fatisfy this inquiry. And for the humours, they are commonly paffed over in anatomies as purgaments; whereas it is moft neceffary to obferve, what cavities, nefts, and receptacles the humours do find in the parts, with the differing kind of the humour fo lodged and received. And as for the footiteps of difeafes and their devaftations of the inward parts, impofthumations, exulcerations, difcontinuations, putrefactions, confumptions, contractions, extenfions, convulfions, diflocations, obftructions, repletions, together with all preternatural fubftances, as ftones, carnofities, excrefcences, worms, and the like; they ought to have been exactly obferved by multitude of anatomies, and the contribution of men's feveral experiences, and care- 
fully fet down, both hiftorically, according to the appearances, and artificially, with a reference to the difeafes and fymptoms which refulted from them, in cafe where the anatomy is of a defunct patient; whereas now, upon opening of bodies, they are paffed over lightly and in filence.

In the inquiry of difeafes, they do abandon the Through cures of many, fome as in their nature incurable, and others as paft the period of cure ; fo that Sylla and the Triumvirs never profcribed fo many men to die, as they do by their ignorant edicts: whereof farbisilibus. numbers do efcape with lefs difficulty than they did in the Roman profcriptions. Therefore I will not doubt to note as a deficience, that they inquire not the perfect cures of many difeafes, or extremities of difeafes; but pronouncing them incurable, do enact a law of neglect, and exempt ignorance from difcredit.

Nay, further, I efteem it the office of a phyfician not only to reftore health, but to mitigate pain and dolours; and not only when fuch mitigation may conduce to recovery, but when it may ferve to make a fair and eafy paffage: for it is no fmall felicity which Auguftus Cæfar was wont to wifh to himfelf, that fame Euthanafia; ${ }^{31}$ and which was efpecially noted in the death of Antoninus Pius, whofe death was after the fafhion and femblance of a kindly and pleafant fleep. So it is written of Epicurus, that after his difeafe was judged defperate, he drowned his ftomach and fenfes with a large draught and ingurgitation of wine; wheredefpair of cures. Inquifirio ulterior de

De Eutha-
nafia exte-
riore. riore.

s) Suet. Vit. Aug. c. 99. 


\section{$174 A D V A N C E M E N T$ OF LEARNING.}

upon the epigram was made, Hinc Stygias ebrius baufit aquas ; ${ }^{32}$ he was not fober enough to tafte any bitternefs of the Stygian water. But the phyficians contrariwife do make a kind of fcruple and religion to ftay with the patient after the difeafe is deplored; whereas, in my judgment, they ought both to inquire the 1 kill and to give the attendances for the facilitating and afluaging of the pains and agonies of death.

Through In the confideration of the cures of difeales, confufion of remedies. I find a deficience in the receipts of propriety, ${ }^{33}$ Medicina refpecting the particular cures and difeafes: for experimen- the phyficians have fruftrated the fruit of traiales. dition and experience by their magiftralities, in adding, and taking out, and changing quid pro quo, in their receipts at their pleafures; commanding fo over the medicine, as the medicine cannot command over the difeafes: for except it be treacle and mitbridatum, ${ }^{34}$ and of late diafcordium, and a few more, they tie themfelves to

32

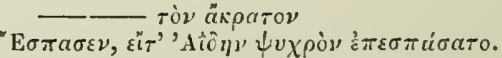

$$
\begin{aligned}
& \text { Diog. Lacrt. x. 15. (Vit. Epic.) }
\end{aligned}
$$

No ebrius here; protenus and latius are fuggefted; but either emendation would rob the ftory of its point.

${ }^{33}$ Receipts of propriety, i. e. proper or fit for each particular difeafe.

34 Treacle and mitbridatum. In the frontifpiece to the ed. of

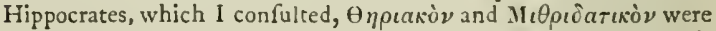
placed fide by fide as the chief remedies. By treacle (tberias) is meant, not the fyrup of fugar, \&c. but a compofition of the parts of vipers; good for the cure of ferpents' bites, and for other medicinal purpofes. Mithridate (from king Mithridates' antidote) was a medicine of general ufe. "Was it not Atrange, a phyfician thould decline exhibiting of Mithridate, becaufe it was a known medicine, and famous for its cures many ages fince?" Boyle's Works, ii. p. 218. Diafordium is faid to have been invented by Fracaltorius. 
no receipts feverely and religiounly: for as to the confections of fale which are in the fhops, they are for readinefs and not for propriety; for they are upon general intention of purging, opening, comforting, altering, and not much appropriate to particular difeafes : and this is the caufe why empirics and old women are more happy many times in their cures than learned phyficians, becaufe they are more religious in holding their medicines. Therefore here is the deficience which I find, that phyficians have not, partly out of their own practice, partly out of the conftant probations reported in books, and partly out of the traditions of empirics, fet down and delivered over certain experimental medicines for the cure of particular difeafes, befides their own conjectura! and magiftral defcriptions. For as they were the men of the beft compofition in the ftate of Rome, which either being confuls inclined to the people, or being tribunes inclined to the fenate; fo in the matter we now handle, they be the beft phyficians, which being learned incline to the traditions of experience, or being empirics incline to the methods of learning.

In preparation of medicines, I do find ftrange, efpecially confidering how mineral medicines have been extolled, ${ }^{3}$ and that they are fafer for the outward than inward parts, that no man hath fought to make an imitation by art of natural baths and medicinable fountains: which neverthelefs are con-

Through neglect of baths, \&cc. Imitationes nature in Balneis :t Aquis $M e-$ dicinalibus.

95 By Paracelfus and his fchool, who were chiefly diftinguined by their ufe of mineral medicines. 


\section{I76 ADVANCEMENT OF LEARNING.}

feffed to receive their virtues from minerals : and not fo only, but difcerned and diftinguifhed from what particular mineral they receive tincture, as fulphur, vitriol, Ateel, or the like; which nature, if it may be reduced to compofitions of art, both the variety of them will be increafed, and the temper of them will be more commanded.

Filum $M_{e}$ - But left I grow to be more particular than is

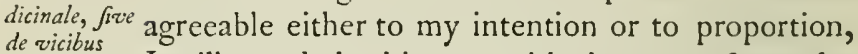
Medicinarum.

I will conclude this part with the note of one deficience more, which feemeth to me of greateft confequence; which is, that the prefcripts in ufe Through are too compendious to attain their end: for, to want of care my underftanding, it is a vain and flattering opinion of medi- to think any medicine can be fo fovereign or fo cines. happy, as that the receipt or ufe of it can work any great effect upon the body of man. It were a ftrange fpeech, which fpoken, or fpoken oft, fhould reclaim a man from a vice to which he were by nature fubject: it is order, purfuit, fequence, and interchange of application, which is mighty in nature; which although it require more exact knowledge in prefcribing, and more precife obedience in obferving, yet is recompenfed with the magnitude of effects. And although a man would think, by the daily vifitations of the phyficians, that there were a purfuance in the cure: yet let a man look into their prefcripts and miniftrations, and he fhall find them but inconftancies and every day's devices, without any fettled providence or project. Not that every fcrupulous or fuperftitious prefcript is effectual, no more than every ftraight way is 


\section{BOOK II.}

the way to heaven; but the truth of the direction muft precede feverity of obfervance. ${ }^{36}$

For Cofmetic, it hath parts civil, and parts effeminate : for cleannefs of body was ever efteemed (3.) Cormetic Art. to proceed from a due reverence to God, to fociety, and to ourfelves. As for artificial decoration, it is well worthy of the deficiences which it hath; being neither fine enough to deceive, nor handfome to ufe, nor wholefome to pleafe.

For Athletic, I take the fubject of it largely, that is to fay, for any point of ability whereunto the ( letic Art. body of man may be brought, whether it be of activity, or of patience; whereof activity hath two parts, frength and fwiftnefs; and patience likewife hath two parts, hardnefs againf wants and extremities, and endurance of pain or torment; whereof we fee the practices in tumblers, in favages, and in thofe that fuffer punifhment: nay, if there be any other faculty which falls not within any of the former divifions, as in thofe that dive, that obtain a Atrange power of containing refpiration, and the like, I refer it to this part. Of thefe things the practices are known, but the philofophy that concerneth them is not much inquired; the rather, I think, becaufe they are fuppofed to be obtained, either by an aptnefs of nature, which cannot be taught, or only by continual cuftom, which is foon prefcribed: which though it be not true, yet I forbear to note any deficiencies: for the Olym-

${ }^{36}$ The paffage in the Latin on the prolongation of Life, which is inferted at this point, is moft curious. It was a fubject to which Bacon had evidently turned his attention; for he often refers to it, and had great hopes refpecting it. 


\section{I78 ADVANCEMENT OF LEARNING.}

pian games are down long fince, and the mediocrity of thefe things is for ufe; as for the excellency of them it ferveth for the moft part but for mercenary oftentation.

(o.) Arts of For arts of pleafure fenfual, the chief deficience pleafure fenfual. in them is of laws to reprefs them. ${ }^{3 i}$ For as it hath been well obferved, that the arts which flourith in times while virtue is in growth, are military; and while virtue is in ftate, are liberal; and while virtue is in declination, are voluptuary; fo I doubt that this age of the world is fomewhat upon the defcent of the wheel. With arts voluptuary I couple practices joculary; for the deceiving of the fenfes is one of the pleafures of the fenfes. As for games of recreation, I hold them to belong to civil life and education. And thus much of that particular human philofophy which concerns the body, which is but the tabernacle of the mind.

De Augm. For Human Knowledge which concerns the Iv. 3 .

(b.) of

Human

Philofophy

as it con-

cerns the

Mind, which regards,

(a.) Its nature.

(及.) Its functions.

(a.) Nature of the Mind. Mind, it hath two parts; the one that inquireth of the fubftance or nature of the foul or mind, the other that inquireth of the faculties or functions thereof. Unto the firft of thefe, the confiderations of the original of the foul, whether it be native or adventive, and how far it is exempted from laws of matter, and of the immortality thereof, and many other points, do appertain: which have been not more laboriouny inquired than varioufly reported; fo as the travail therein taken feemeth to have been rather in a maze than in a way.

${ }^{37}$ This fubject is very differently treated in the Latin. He there introduces mufic and painting, not as things to be repreffed, but honoured. 
But although I am of opinion that this knowledge may be more really and foundly inquired, even in nature, than it hath been; yet I hold that in the end it muft be bounded by religion, or elfe it will be fubject to deceit and delufion: for as the fubftance of the foul in the creation was not extracted out of the mafs of heaven and earth by the benediction of a producat but was immediately infpired from God: fo it is not poffible that it fhould be (otherwife than by accident) fubject to the laws of heaven and earth, which are the fubject of philofophy; and therefore the true knowledge of the nature and fate of the foul muft come by the fame infpiration that gave the fubftance. Unto this part of knowledge touching the foul there be two appendices; which, as they have been handled, have rather vapoured forth fables than kindled truth, Divination and Fafcination.

Divination hath been anciently and fitly divided (Appendix into artificial and natural; whereof artificial is, when the mind maketh a prediction by argument, concluding upon figns and tokens; natural is when the mind hath a prefention by an internal power, without the inducement of a fign. Artificial is of two forts; either when the argument is coupled with a derivation of caufes, which is rational; or when it is only grounded upon a coincidence of the effect, which is experimental: whereof the latter for the moft part is fuperftitious; fuch as were the heathen obfervations upon the infpection of facrifices, the flights of birds, the fwarming of bees; and fuch as was the Chaldean

i.)

Divination. 
aftrology, and the like. For artificial divination, the feveral kinds thereof are diftributed amongft particular knowledges. The aftronomer hath his predictions, as of conjunctions, afpects, eclipfes, and the like. The phyfician hath his predictions of death, of recovery, of the accidents and iffues of difeafes. The Politique hath his predictions; $O$ urbem venalem, et cito perituram, fi emptorem invenerit! ${ }^{38}$ which ftayed not long to be performed, in Sylla firf, and after in Cæefar. So as thefe predictions are now impertinent, and to be referred over. But the divination which fpringeth from the internal nature of the foul, is that which we now fpeak of; which hath been made to be of two fors, primitive and by influxion. Primitive is grounded upon the fuppofition, that the mind, when it is withdrawn and collected into itfelf, and not diffufed into the organs of the body, hath fome extent and latitude of prenotion; which therefore appeareth moft in fleep, in ecftacies, and near death, and more rarely in waking apprehenfions; and is induced and furthered by thofe abftinences and obfervances which make the mind moft to confift in itfelf. By influxion, is grounded upon the conceit that the mind, as a mirror or glafs, fhould take illumination from the foreknowledge of God and fpirits: ${ }^{39}$ unto which the fame regiment doth likewife conduce. For the retiring of the mind within itfelf, is the fate which is moft fufceptible of divine influxions; fave that

${ }^{38}$ Sall. Fug. c. $\times \times \times \nabla$.

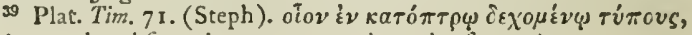
and note the obfervation on $\mu a \nu \tau(\kappa)$, at the fame place. 
it is accompanied in this cafe with a fervency and elevation, which the ancients noted by fury, and not with a repore and quiet, as it is in the other.

Fafcination is the power and act of imagination intenfive upon other bodies than the body of the imaginant, for of that we fpake in the proper (Appendix ii.) Faf́cination. place: wherein the fchool of Paracelfus, and the difciples of pretended Natural Magic have been fo intemperate, as they have exalted the power of the imagination to be much one with the power of miracle-working faith; others, that draw nearer to probability, calling to their view the fecret paffages of things, and fpecially of the contagion that paffeth from body to body, do conceive it hould likewife be agreeable to nature, that there fhould be fome tranfmiffions and operations from fpirit to fpirit without the mediation of the fenfes; whence the conceits have grown, now almoft made civil, of the maftering fpirit, and the force of confidence, and the like. Incident unto this is the inquiry how to raife and fortify the imagination: for if the imagination fortified have power, then it is material to know how to fortify and exalt it. And herein comes in crookedly and dangerouny a palliation of a great part of Ceremonial Magic. For it may be pretended that Ceremonies, Characters, and Charms, do work, not by any tacit or facramental contract with evil fpirits, but ferve only to ftrengthen the imagination of him that ufeth it: as images are faid by the Roman church to fix the cogitations, and raife the devotions of them that pray before them. But for mine own judgment, if it be admitted that imagination hath power, and 


\section{$182 A D V A N C E M E N T$ OF LEARNING.}

that Ceremonies fortify imagination, and that they be ufed fincerely and intentionally for that purpofe; ${ }^{40}$ yet I thould hold them unlawful, as oppofing to that firft edict which God gave unto man, In fudore vultus comedes panem tuum. ${ }^{41}$ For they propound thofe noble effects, which God hath fet forth unto man to be bought at the price of labour, to be attained by a few eafy and flothful obfervances. Deficiences in thefe knowledges I will report none, other than the general deficience, that it is not known how much of them is verity, and how much vanity. ${ }^{42}$

De Aug. v. i.

( $\beta$.$) Of the$ functions of the mind. Thefe are, (A.) Intellectual.

(B.) Moral.

The Knowledge which refpecteth the faculties of the mind of man is of two kinds ; the one refpecting his Underftanding and Reafon, and the other his Will, Appetite, and Affection; whereof the former produceth Pofition or Decree, the latter Action or Execution. It is true that the Imagination is an agent or nuncius, in both provinces, both the judicial and the minifterial. For Senfe fendeth over to Imagination before Reafon have judged: and Reafon fendeth over to Imagination before the decree can be anted: for Imagination ever precedeth Voluntary Motion. Saving that this Janus of Imagination hath differing faces: for the face towards Reafon hath the print of Truth,

10 Ceremonies. The word does not now convey quite the fame fenfe; for in thefe paffages Bacon refers to invocation of fpirits: faying (as we gather alfo from the Latin) that they are illicit, though ufed only as phyfical remedies without any incantation.

41 Gen. iii. 19.

42 In the Latin, two defiderata are noticed; Voluntary Motion, and Senfe and the Senfible: together with a curious difcourfe on the Form of Light. 
but the face towards Action hath the print of Good; which neverthelefs are faces,

Quales decet efre fororum. ${ }^{13}$

Neither is the Imagination fimply and only a meffenger; but is invefted with, or at leaftwife ufurpeth no fmall authority in itfelf, befides the duty of the meffage. For it was well faid by Ariftotle, That the mind bath over the body that commandment, which the lord hath over a bondman; but that reafon hath over the imagination that commandment which a magiftrate hath over a free citizen $;^{44}$ who may come alfo to rule in his turn. For we fee that, in matters of Faith and Religion, we raife our Imagination above our Reafon; which is the caufe why Religion fought ever accefs to the mind by fimilitude, types, parables, vifions, dreams. And again, in all perfuafions that are wrought by eloquence, and other impreflions of like nature, which do paint and difguife the true appearance of things, the chief recommendation unto Reafon is from the Imagination. ${ }^{45}$ Neverthelers, becaufe I find not any fcience that doth properly or fitly pertain to the Imagination, I fee no caufe to alter the former divifion. For as for poefy, it is rather a pleafure or play of Imagination, than a work or duty thereof. And if it be a work, we fpeak not now of fuch parts of learning as the Imagination produceth, but of fuch fciences as handle and con-

43 Ovid, Metam. ii. 14.

44 Ariftot. Polit. i. 5, 6; where ö $\rho \xi \xi \varsigma$, appetite, is the term here rendered by imagination.

45 i.e. Rhetoric aims at the feelings rather than at the cool judgment, and inflames Imagination till the overpowers Reafon. 


\section{$184 A D V A N C E M E N T$ OF LEARNING.}

fider of the Imagination; no more than we fhall fpeak now of fuch knowledges as reafon produceth, for that extendeth to all philofophy, but of fuch knowledges as do handle and inquire the faculty of reafon: fo as poefy had its true place. As for the power of the Imagination in nature, and the manner of fortifying the fame, we have mentioned it in the doctrine De Anima, whereunto it moft fitly belongeth. And laftly, for Imaginative or Infinuative Reafon, which is the fubject of Rhetoric, we think it beft to refer it to the Arts of Reafon. So therefore we content ourfelves with the former divifion, that human philofophy, which refpecteth the faculties of the mind of man, hath two parts, rational and moral.

(A.) Intellectual.
The part of human philofophy which is rational, is of all knowledges, to the moft wits, the leaft delightful; and feemeth but a net of fubtilty and fpinofity. For as it was truly faid, that knowledge is Pabulum animi, ${ }^{46}$ fo in the nature of men's appetite to this food, moft men are of the tafte and ftomach of the Ifraelites in the defert, that would fain have returned ad ollas carnium, ${ }^{47}$ and were weary of manna; which, though it were celeftial, yet feemed lefs nutritive and comfortable. So generally men tafte well knowledges that are drenched in flefh and blood, civil hiftory, morality, policy, about the which men's affections, praifes,

46 Cic. Acad. iv. ad Lucu!lum, 32. a. (Steph. 225.) Eft enim animorum ingeniorumque naturale quoddam quafi pabulum confideratio contemplatioque naturæ. Or perhaps, De SeneE. I4. Si habet aliquid tanquam pabulum frudii atque doctrina, nihil eft otiofa fenectute jucundius.

47 Numb. xi. 4-6. 
fortunes do turn and are converfant; but this fame lumen ficcum doth parch and offend moft men's watery and foft natures. But, to fpeak truly of things as they are in worth, Rational Knowledges are the keys of all other arts, for as Ariftotle faith, aptly and elegantly, That the band is the inftrument of inftruments, and the mind is the form of forms: 48 fo thefe be truly faid to be the art of arts: neither do they only direct, but likewife confirm and ftrengthen: even as the habit of thooting doth not only enable to thoot a nearer fhoot, but alfo to draw a Atronger bow.

The Arts intellectual are four in number; di- Whofe Arts vided according to the ends whereunto they are are four. referred: for man's labour is to invent that which is fought or propounded; or to judge that which is invented; or to retain that which is judged; or to deliver over that which is retained. So as the arts muft be four: Art of Inquiry or Invention: Art of Examination or Fudgment: Art of Cufody or Memory: and Art of Elocution or Tradition.

Invention is of two kinds, much differing: the one of Arts and Sciences; and the other of Speech and Arguments. The former of thefe I do report deficient; which feemeth to me to be fuch a deficience as if in the making of an inventory touching the eftate of a defunct it fhould be fet down that there is no ready noney. For as money will fetch all other commodities, fo this knowledge is that which hould purchafe all the reft. And like as the Weft Indies had never been difcovered if the

${ }^{18}$ Ariftot. De Anima, iii. 8.

De Aug. v. (i.) Art of Invention. (a.) Of Arts is deficient. 


\section{I86 ADVANCEMENT OF LEARNING.}

ufe of the mariner's needle had not been firit difcovered, though the one be vaft regions, and the other a fmall motion; fo it cannot be found Atrange if fciences be no farther difcovered, if the art itfelf of invention and difcovery hath been paffed over.

Not provided by Logic.

That this part of knowledge is wanting, to my judgment ftandeth plainly confeffed; for firft, Logic doth not pretend to invent fciences, or the axioms of fciences, but paffeth it over with a Cuique in fua arte credendum. ${ }^{49}$ And Celfus acknowledgeth it gravely, fpeaking of the Empirical and dogmatical fects of phyficians, That medicines and cures were firft found out, and then after the reafons and caufes were difcourfed; and not the caufes firf found out, and by light from them the medicines and cures difcovered. ${ }^{50}$ And Plato, in his Theaetetus, noteth well, That particulars are infinite, and the bigher generalities give no fufficient direction: and that the pith of all fciences, which maketh the artfman differ from the inexpert, is in the middle propofitions, which in every particular knowledge are taken from tradition and experience. ${ }^{51}$ And therefore we fee, that they which difcourfe of the inventions and originals of things, refer them rather to chance than to art, and rather to beafts, birds, filhes, ferpents, than to men.

49 Ellis and Spedding refer to Arift. Anal. Pr. i. $30 ; \mathrm{Mr}$. Markby to Eth. Mag. I. i. 17. Ariftotle declares (Rbet. I. i. 1) that neither Rhetoric nor Logic has any proper fubject-matter, both being purely inftrumental; accordingly neither can " invent fciences."

${ }_{50}$ De Re Med. i. x.

51 Not in the Theatetus certainly. As Bacon in the Latin introduces the quotation with Plato non fomel innuit, he probably is not quoting any exact paffage. 
Dictamnum genitrix Cretæa carpit ab Ida,
Puberibus caulem foliis et flore comantem
Purpureo; non illa feris incognita capris
Gramina, cum tergo volucres hæfere fagittæ. ${ }^{32}$

So that it was no marvel, the manner of antiquity being to confecrate inventors, that the Egyptians had fo few human idols in their temples, but almoft all brute.

Omnigenumque Deum monftra, et latrator Anubis,

Contra Neptunum, et Venerem, contraque Minervam, \&c, ${ }^{53}$

And if you like better the tradition of the Grecians, and afcribe the firft inventions to men; yet you will rather believe that Prometheus firft Aruck the flints, and marvelled at the fpark, than that when he firft ftruck the flints he expected the fpark : and therefore we fee the Weft Indian Prometheus ${ }^{54}$ had no intelligence with the European, becaufe of the rarenefs with them of flint, that gave the firft occafion. So as it fhould feem, that hitherto men are rather beholding to a wild goat for furgery, or to a nightingale for mufic, or to the ibis for fome part of phyfic, or to the pot-lid that flew open for artillery, or generally to chance, ${ }^{55}$ or anything elfe, than to logic, for the invention of arts and fciences. Neither is the form of invention which Virgil defcribeth much other:

Ut varias ufus meditando extunderet artes Paulatim. ${ }^{56}$

For if you obferve the words well, it is no other

52 Virg. $E_{n}$, xii. 412.

53 Ibid. viii. 698 .

54 Refers, doubtlefs, to the rubbing of two fticks together to produce fire. Cf. Nov. Org. 3s. ii. I 6 .

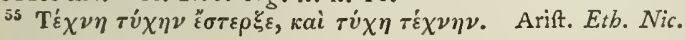
vi. 4 .

56 Georg. i. 133. 


\section{I88 ADVANCEMENT OF LEARNING.}

method than that which brute beafts are capable of, and do put in ure ; which is a perpetual intending or practifing fome one thing, urged and impofed by an abfolute neceflity of confervation of being; for fo Cicero faith very truly, Ufus uni rei deditus et naturam et artem fepe vincit. ${ }^{57}$ And therefore if it be faid of men,

\section{Labor omnia vincit}

Improbus, et duris urgens in rebus egeftas $!^{58}$

it is likewife faid of beafts,

\section{Quis pfittaco docuit fuum $\chi a$ ẵ ? $^{59}$}

Who taught the raven in a drought to throw pebbles into a hollow tree, where the efpied water, that the water might rife fo as the might come to it ? Who taught the bee to fail through fuch a valt fea of air, and to find the way from a field in flower a great way off to her hive? Who taught the ant to bite every grain of corn that the burieth in her hill, left it hould take root and grow? Add then the word extundere, which importeth the extreme difficulty, and the word paulatim, which importeth the extreme flownefs, and we are where we were, even amongtt the Egyptians' gods; there being little left to the faculty of reafon, and nothing to the duty of art, for matter of invention.

Neither by

Secondly, the Induction which the Logicians Induction. fpeak of, and which feemeth familiar with Plato, (whereby the Principles of Sciences may be pretended to be invented, and fo the middle propofi-

57 Cic. p. Corn. Balb. xx. 45. 59 Pers. Prol. 8, where it is expedivit. 
tions by derivation from the Principles;) their form of induction, I fay, is utterly vicious and incompetent: wherein their error is the fouler, becaufe it is the duty of Art to perfect and exalt Nature; but they contrariwife have wronged, abufed, and traduced Nature. For he that fhall attentively obferve how the mind doth gather this excellent dew of knowledge, like unto that which the poet fpeaketh of,

\section{Aërei mellis coeleftia dona, ${ }^{60}$}

diftilling and contriving it out of particulars natural and artificial, as the flowers of the field and garden, thall find that the mind of herfelf by nature doth manage and act an induction much better than they defcribe it. For to conclude upon an enumeration of particulars, without inftance contradictory, is no conclufion, but a conjecture; for who can affure, in many fubjects, upon thofe particulars which appear of a fide, that there are not other on the contrary fide which appear not? As if Samuel fhould have refted upon thore fons of Jeffe ${ }^{61}$ which were brought before him, and failed of David, which was in the field.62 And this form, to fay truth, is fo grofs, as it had not been poffible for wits fo fubtile as have managed thefe things to have offered it to the world, but that they hafted to their theories and dogmaticals, and were imperious and fcornful toward particulars; which their manner was to

60 Virg. Georg. iv. I.

61 All the old editions fpell the word Ifray, and the De Augm. (as a genitive) Ifä.

62 I Sam. xvi. 


\section{I90 ADVANCEMENT OF LEARNING.}

ufe but as liciores and viatores, for ferjeants and whifflers, ad Jummovendam turbam, to make way and make room for their opinions, rather than in their true ufe and fervice. Certainly it is a thing may touch a man with a religious wonder, to fee how the footfteps of feducement are the very fame in divine and human truth: for as in divine truth man cannot endure to become as a child; fo in human, they reputed the attending the inductions whereof we fpeak, as if it were a fecond infancy or childhood.

Nor by Syl- Thirdly, allow fome principles or axioms were logifm. rightly induced, yet neverthelefs certain it is that middle propofitions cannot be deduced from them in fubject of nature ${ }^{63}$ by fyllogifm, that is, by touch and reduction of them to principles in a middle term. It is true that in fciences popular, as moralities, laws, and the like, yea, and divinity, (becaufe it pleafeth God to apply himfelf to the capacity of the fimpleft,) that form may have ufe; and in natural philofophy likewife, by way of argument or fatisfactory reafon, 2uce afjenfum parit, operis effota eft: ${ }^{6+}$ but the fubtlety of nature and operations will not be enchained in thofe bonds: for arguments confift of propofitions, and propofitions of words; and words are but the current tokens or marks ${ }^{65}$ of popular notions of things; which notions, if they be grofly and variably col-

63 In the Latin, in rebus naturalibus.

64 This quotation is omitted in the Latin, nor can I find whence it comes; could it be a faying of Bacon's own?

65 Tefferæ. Arift. Interp. 1. 1. 2- $\tau \dot{a} \tau \tilde{\omega} \nu \dot{\varepsilon} \nu \tau \tilde{y} \psi v \chi \tilde{y} \pi a \theta \eta$ $\mu \alpha \dot{\tau} \omega \nu$ бí $\mu \beta о \lambda \alpha$. 
lected out of particulars, it is not the laborious examination either of confequence of arguments, or of the truth of propofitions, that can ever correct that error, being, as the phyficians fpeak, in the firft digertion: and therefore it was not without caufe, that fo many excellent philofophers became Sceptics and Academics, and denied any certainty of knowledge or comprehenfion; and held opinion that the knowledge of man extended only to appearances and probabilities. It is true that in Socrates it was fuppofed to be but a form of irony, Scientiam diffimulando fimulavit, ${ }^{66}$ for he ufed to difable his knowledge, to the end to enhance his knowledge: like the humour of Tiberius in his beginnings, that would reign, but would not acknowledge fo much: ${ }^{67}$ and in the later Academy, which Cicero embraced, this opinion alfo of acatalep $\sqrt{i} a,{ }^{68}$ I doubt, was not held fincerely: for that all thofe which excelled in copie of fpeech feem to have chofen that fect, as that which was fitteft to give glory to their eloquence and variable difcourfes; being rather like progreffes of pleafure, than journeys to an end. But affuredly many fcattered in both Academies did hold it in fubtilty and integrity: but here was their chief error; they charged the deceit upon the fenfes; which in my judgment, notwithftanding all their cavillations, are very fufficient to certify

${ }_{66}$ Cic. Acad. ii. 5. 1 5. Cf. Cic. ad Att. xiii. 19. 3. Thefe very words do not occur.

67 Tac. Ann. i. 7. 11 .

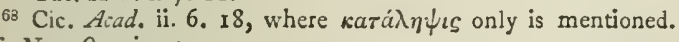
Cr., Nov. Org. i. 37 . 


\section{I92 ADVANCEMENT OF LEARNING.}

and report truth, though not always immediately, yet by comparifon, by help of inftrument, and by producing and urging fuch things as are too fubtile for the fenfe to fome effect comprehenfible by the fenfe, and other like affiftance. But they ought to have charged the deceit upon the weaknefs of the intellectual powers, and upon the manner of collecting and concluding upon the reports of the fenfes. This I fpeak, not to difable the mind of man, but to ftir it up to feek help: for no man, be he never fo cunning or practifed, can make a ftraight line or perfect circle by fteadinefs of hand, which may be eafily done by help of a ruler or compafs.

This part left to the future.

This part of invention, concerning the invention of fciences, I purpole, if God give me leave, hereafter to propound, having digefted it into two parts; whereof the one I term experientia literata, and the other interpretatio nature: the former being but a degree and rudiment of the latter. But I will not dwell too long, nor fpeak too great upon a promife. ${ }^{69}$

De Aug. v.

The invention of fpeech or argument is not 3.

(3.) Of properly an invention, for to invent is to difcover Speech (not that we know not, and not to recover or refumtrue Inven- mon that which we already know: and the ufe of tion). this invention is no other but out of the knowledge whereof our mind is already poffeffed to draw forth or call before us that which may be

69 In the Latin, Bacon explains his experientia literata, which treats of methods of experiment; Venatio Panis he alfo ftyles it. Cf. Nov. Org. i. Ior. The Interpretatio Natura is the fubjectmatter of the Now. Org. 
pertinent to the purpofe which we take into our confideration. So as to fpeak truly, it is no invention, but a remembrance or fuggeftion, with an application; which is the caufe why the fchools do place it after judgment, as fubfequent and not precedent. Neverthelefs, becaufe we do account it a chafe as well of deer in an inclofed park as in a foreft at large, and that it hath already obtained the name, let it be called invention : $f_{0}$ as it be perceived and difcerned, that the fcope and end of this invention is readinefs and prefent ufe of our knowledge, and not addition or amplification thereof.

To procure this ready ufe of knowledge there are two courfes, Preparation and Suggeftion. By Preparation. The former of thefe feemeth farcely a part of knowledge, confifting rather of diligence than of any artificial erudition. And herein Ariftotle wittily, but hurtfully, doth deride the Sophifts near his time, faying, They did as if one that profeffed the art of Shoe-making Jould not teach bow to make a hoe, but only exhibit in a readiness a number of phoes of all faßhions and jzes. ${ }^{70}$ But yet a man might reply, that if a fhoemaker fhould have no fhoes in his fhop, but only work as he is befpoken, he fhould be weakly cuftomed. But our Saviour, fpeaking of divine knowledge, faith, that the kingdom of heaven is like a good houfebolder, that bringeth forth both new and old ftore $:^{71}$ and we fee the ancient writers of Rhetoric do give it in precept, " that pleaders fhould have the 


\section{$194 A D V A N C E M E N T$ OF LEARNING.}

Places, whereof they have moft continual ufe, ready handled in all the variety that may be ;" as that, "to fpeak for the literal interpretation of the law againft equity, and contrary; and to fpeak for prefumptions and inferences againft teftimony, and contrary." is And Cicero himfelf, being broken unto it by great experience, delivereth it plainly, that whatfoever a man fhall have occafion to fpeak of, if he will take the pains, he may have it in effect premeditate, and handled, in the $f_{i} ; 7^{3}$ fo that when he cometh to a particular he fhall have nothing to do, but to put to names and times and places, and fuch other circumftances of individuals. We fee likewife the exact diligence of Demothenes; who, in regard of the great force that the entrance and accefs into caufes hath to make a good impreffion, had ready framed a number of prefaces for orations and fpeeches. All which authorities and precedents may overweigh Ariftotle's opinion, that would have us change a rich wardrobe for a pair of Thears.

But the nature of the collection of this provifion or preparatory ftore, though it be common both to Logic and Rhetoric, yet having made an entry of it here, where it came firft to be fpoken of, I think fit to refer over the further handling of it to Rhetoric.

By Suggef- The other part of invention, which I term fugtion. geftion, doth affign and direct us to certain marks,

72 In the ed. 1605 , thefe paffages are printed in black letter, as quotations.

73 Cic. Orat. $14(46)$. 
or places, which may excite our mind to return and produce fuch knowledge as it hath formerly collected, to the end we may make ufe thereof. Neither is this ufe, truly taken, only to furnifh argument to difpute probably with others, but likewife to minifter unto our judgment to conclude aright within ourfelves. Neither may thefe Places ferve only to apprompt our invention, but alfo to direct our inquiry. For a faculty of wife interrogating is half a knowledge. For as Plato faith, IVbofoever feeketh, knoweth that which be feeketh for in a general notion: else bow frall be know it when be bath found it? it and therefore the larger your anticipation is, the more direct and compendious is your fearch. But the fame Places which will help us what to produce of that which we know already, will alfo help us, if a man of experience were before us, what queftions to afk; or, if we have books and authors to inftruct us, what points to fearch and revolve; fo as I cannot report that this part of invention, which is that which the fchools call Topics, is deficient. ${ }^{i 5}$

Neverthelefs, Topics are of two forts, general of Topics. and fpecial. ${ }^{6}$ The general we have fpoken to; but the particular hath been touched by fome, but rejected generally as inartificial and variable. But leaving the humour which hath reigned too much in the fchools, which is, to be vainly fubtle in a few things which are within their command, and

74 Plato, Menon. 80.

75 This paffage is better arranged in the Latin. The paragraphs on Topics look as if they had been inferted as an afterthought.

${ }_{76}$ Cf. Ariftot. Rbet. 15. xxii. 16, 17. 


\section{I96 ADVANCEMENT OF LEARNING.}

to reject the reft; I do receive particular Topics, (that is, places or directions of invention and inquiry in every particular knowledge,) as things of great ufe, being mixtures of. Logic with the matter of fciences; for in thefe it holdeth, ars inveniendi adolefit cum inventis; 7 for as in going of a way, we do not only gain that part of the way which is paffed, but we gain the better fight of that part of the way which remaineth : fo every degree of proceeding in a fcience giveth a light to that which followeth; which light if we frengthen by drawing it forth into queftions or places of inquiry, we do greatly advance our purfuit. ${ }^{78}$

De Augm. Now we pafs unto the arts of Judgment, which v. 4 .

(ii.) Art of Judgment. handle the natures of Proofs and Demonftrations; which as to Induction hath a coincidence with In Induction.

Invention. For in all inductions, whether in good or vicious form, the fame action of the mind which inventeth, judgeth; all one as in the fenfe. But otherwife it is in proof by fyllogifm; for the proof being not immediate, but by mean, the invention of the mean is one thing, and the judgment of the confequence is another; the one exciting only, the other examining. Therefore for the real and exact form of judgment, we refer ourfelves to that which we have fpoken of interpretation of nature..$^{79}$

By Syllogirm.
For the other judgment by Syllogifm, as it is a thing moft agreeable to the mind of man, fo it

7 Cf. Nov. Org. i. 130.

${ }^{78}$ In the Latin an inquiry de gravi ef levi is here added as a Topic.

79 In the Latin, legitimam (Inductionis formam) ad Novum Or. ganum remittimus. 
hath been vehemently and excellently laboured; for the nature of man doth extremely covet to have fomewhat in his underftanding fixed and immovable, and as a reft and fupport of the mind. And therefore as Ariftotle endeavoureth to prove, that in all motion there is fome point quiefcent ${ }^{80}$ and as he elegantly expoundeth the ancient fable of Atlas, that ftood fixed, and bare up the heaven from falling, to be meant of the poles or axle-tree of heaven, whereupon the converfion is accomplifhed; fo affuredly men have a defire to have an Atlas or axle-tree within to keep them from fluctuation, which is like to a perpetual peril of falling; therefore men did haften to fet down fome principles about which the variety of their difputations might turn.

So then this art of Judgment is but the reduction of propofitions to principles in a middle term : Judgment defined. the principles to be agreed by all and exempted from argument; the middle term to be elected at the liberty of every man's invention; the reduction to be of two kinds, direct and inverted; the one when the propofition is reduced to the principle, which they term a probation oftenfive; the other, when the contradictory of the propofition is reduced to the contradictory of the principle, which is that which they call per incommodum, or prefjing an abfurdity; the number of middle terms to be as the propofition ftandeth degrees more or lefs removed from the principle. ${ }^{81}$

${ }^{2}$ Ariftot. De Motu Anim. 3 . 81 Cf. Sanderfon, Logic, iii. 5. 


\section{I98 ADVANCEMENT OF LEARNING.}

Its methods. But this art hath two feveral methods of doc(a.) Of direction. (Analytics.) trine, the one by way of direction, the other by way of caution: the former frameth and fetteth down a true form of confequence, by the variations and deflections from which errors and inconfequences may be exactly judged. Toward the compofition and fructure of which form, it is incident to handle the parts thereof, which are propofitions, and the parts of propofitions, which are fimple words: and this is that part of Logic which is comprehended in the Analytics.

(b.) Of cau- The fecond method of doctrine was introduced tion. (Elenches.) for expedite ufe and affurance fake; difcovering the more fubtle forms of fophifms and illaqueations with their redargutions, which is that which is termed elenches. For although in the more grols forts of fallacies it happeneth, as Seneca maketh the comparifon well, as in juggling feats, which, though we know not how they are done, yet we know well it is not as it feemeth to be ; ${ }^{82}$ yet the more fubtle fort of them doth not only put a man befide his anfwer, but doth many times abufe his judgment.

Elenches, how treated by Ariftotle and Plato.

This part concerning elenches is excellently handled by Ariftotle in precept, but more excellently by Plato in example, not only in the perfons of the Sophifts, but even in Socrates himfelf; who, profeffing to affirm nothing, but to infirm that which was affirmed by another, hath exactly expreffed all the forms of objection, fallacy, and

E2 Sen. Epif. Mor. 45. Sine noxa decipiunt, quomodo præftigiatorum acetabula et calculi, in quibus fallacia ipfa delectat. 


\section{BOOK II.}

redargution. ${ }^{83}$ And although we have faid that the ufe of this doctrine is for redargution, yet it is manifeft the degenerate and corrupt ufe is for caption and contradiction, which paffeth for a great faculty, and no doubt is of very great advantage: though the difference be good which was made between orators and fophifters, that the one is as the greyhound, which hath his advantage in the race, and the other as the hare, which hath her advantage in the turn, fo as it is the advantage of the weaker creature.

But yet further, this doctrine of elenches hath a more ample latitude and extent than is perceived; namely, unto divers parts of knowledge; whereof fome are laboured and others omitted. For firft, I conceive, though it may feem at firft fomewhat ftrange, that that part which is variably referred, fometimes to logic, fometimes to metaphyfics, touching the common adjuncts of effences, is but an elench; for the great fophifm of all fophifms being equivocation, or ambiguity of words and phrafe, (efpecially of fuch words as are moft general, and intervene in every inquiry,) it feemeth to me that the true and fruitful ufe, leaving vain fubtilties and fpeculations, of the inquiry of majority, minority, priority, pofteriority, identity, diverfity, poffibility, act, totality, parts, exiftence, privation, and the like, are but wife cautions againit the ambiguities of peech. So again the diftribution of things into certain tribes, which we call catego-

${ }^{83}$ Cf. Plato's account of Socrates in the opening of the Tbeatctus.

Capable of further extenfion. 
ries or predicaments, are but cautions againft the confufion of definitions and divifions. ${ }^{84}$

Imagination Secondly, there is a feducement that worketh affeets judg- by the ftrength of the impreffion, and not by the
ment. fubtilty of the illaqueation; not fo much perplexing the reafon, as overruling it by power of the imagination. But this part I think more proper to handle when I hall fpeak of rhetoric.

Fallacies in the mind.

But laftly, there is yet a much more important and profound kind of fallacies in the mind of man, which I find not obferved or inquired at all, 85 and think good to place here, as that which of all others appertaineth moft to rectify judgment : the force whereof is fuch, as it doth not dazzle or fnare the underftanding in fome particulars, but doth more generally and inwardly infect and corrupt the ftate thereof. For the mind of man is far from the nature of a clear and equal glafs, wherein the beams of things thould reflect according to their true incidence; nay, it is rather like an enchanted glass, full of fuperftition and importure, if it be not delivered and reduced. For this purpole, let us confider the falfe appearances that are impofed upon us by the general nature of the mind, ${ }^{86}$ beholding them in an example or two; as firft, in that inftance which is the root of all fupertition, namely, That to the nature of the mind of all men it is confonant for the affirmative or active to affect more than the negative or pri-

54 Arif. Categ.

${ }^{65}$ This is the doctrine of "Idols," expanded in the Latin, and ftill more in the Nov. Org. i. 39-68.

so "Idols" of the Tribe, Nov. Org. i. 24-31. 
vative: fo that a few times hitting or prefence, countervails oft-times failing or abfence; as was well anfwered by Diagoras to him that howed him in Neptune's temple the great number of pictures of fuch as had efcaped hipwreck, and had paid their vows to Neptune, faying, Advife now, you that think it folly to invocate Neptune in

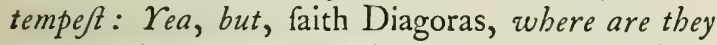
painted that are drozuned? 87 Let us behold it in another inftance, namely, That the fpirit of man, being of an equal and uniform fubfance, doth ufually fuppofe and feign in nature a greater equality and uniformity than is in truth. Hence it cometh, that the mathematicians cannot fatisfy themfelves except they reduce the motions of the celeftial bodies to perfect circles, rejecting fpiral lines, and labouring to be difcharged of eccentrics. ${ }^{88}$ Hence it cometh, that whereas there are many things in nature as it were monodica, fui juris; ${ }^{89}$ yet the cogitations of man do feign unto them relatives, parallels, and conjugates, whereas no fuch thing is; as they have feigned an element of fire, to keep fquare with earth, water, and air, and the like : nay, it is not credible, till it be opened, what a number of fictions and fancies the fimilitude of human actions and arts, together with the making of man communis menfura, have brought into na-

87 Cic. De Nat. Deor. iii. 37.

${ }^{88}$ Bacon's warning here is good, though his illuftration was foon fignally confuted by the promulgation of Kepler's laws. See Nov. Org. i. 45.

${ }^{69} \mathrm{He}$ feems to think the derivation of this term is $\mu$ ó $\nu$ os and

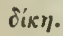




\section{ADVANCEMENT OF LEARNING.}

tural philofophy; not much better than the herefy of the Anthropomorphites, ${ }^{90}$ bred in the cells of grofs and folitary monks, and the opinion of Epicurus, anfwerable to the fame in heathenifm, who fuppofed the Gods to be of human thape. And therefore Velleius the Epicurean needed not to have afked, why God fhould have adorned the heavens with ftars, as if he had been an cdilis, one that fhould have fet forth fome magnificent fhows or plays.91 For if that great Work-mafter had been of a human difpofition, he would have caft the ftars into fome pleafant and beautiful works and orders, like the frets in the roofs of houfes; whereas one can fcarce find a pofture in fquare, or triangle, or ftraight line, amongft fuch an infinite number; fo differing a harmony there is between the fpirit of man and the fpirit of nature.

Phantoms

Let us confider again the falfe appearances imof the Cave. pofed upon us by every man's own individual nature and cuftom, 92 in that feigned fuppofition that Plato ${ }^{33}$ maketh of the cave: for certainly if a child were continued in a grot or cave under the earth until maturity of age, and came fuddenly abroad, he would have ftrange and abfurd imaginations. So in like manner, although our perfons live in the view of heaven, yet our fpirits are

90 Anthropomorphites, a fect which flourined in the fourth and tenth centuries; their diftinctive doctrine was that as God is faid to have made man in his own Image, therefore the Deity is clothed in human thape. See Morheim, Ectl. Hift. Cent. x. part ii. ch. 5 .
91 Cic. De Nat. Deor. i. 9.
92 "Idols" of the Cave, Now. Org. i. 31-35.
${ }^{93}$ Plato, De Rep. lib. vii. init. 
included in the caves of our own complexions and cuftoms, which minifter unto us infinite errors and vain opinions, if they be not recalled to examination. But hereof we have given many examples in one of the errors, or peccant humours, which we ran briefly over in our firft book.

And laftly, let us confider the falfe appearances that are impofed upon us by words, which are Of the Market-place. framed and applied according to the conceit and capacities of the vulgar fort: and although we think we govern our words, and prefcribe it well, loquendum ut vulgus, fentiendum ut fapientes; yet certain it is that words, as a Tartar's bow, do fhoot back upon the underftanding of the wifeft, and mightily entangle and pervert the judgment. So as it is almoft neceffary in all controverfies and difputations to imitate the wifdom of the mathematicians, in fetting down in the very beginning the definitions of our words and terms, that others may know how we accept and underftand them, and whether they concur with us or no. For it cometh to pals for want of this, that we are fure to end there where we ought to have begun, which is, in queftions and differences about words. To conclude therefore, it muft be confeffed that it is not poffible to divorce ourfelves from thefe fallacies and falfe appearances, becaufe they are infeparable from our nature and condition of life; fo yet neverthelefs the caution of them, (for all elenches, as was faid, are but cautions,) doth extremely import the true conduct of human

Elencbi magni, five de Idolis animi humani nativis et adventitiis. 


\section{$204 A D V A N C E M E N T$ OF LEARNING.}

judgment. The particular elenches or cautions againt thefe three falfe appearances, I find altogether deficient.

Reference There remaineth one part of judgment of great of proofs to their fubjects deficient.

excellency, which to mine underftanding is fo flightly touched, as I may report that alfo deficient; which is the application of the differing kinds of proofs to the differing kinds of fubjects; for there being but four kinds of demonftrations, that is, by the immediate confent of the mind or fenee, by induction, by fyllogifm, and by congruity (which is that which Ariftotle calleth demonftration in orb or circle, ${ }^{9 t}$ and not a notioribus;) every of thefe hath certain fubjects in the matter of fciences, in which refpectively they have chiefeft ufe; and certain others, from which refpectively they ought to be excluded; and the rigour and curiofity in requiring the more fevere proofs in fome things, and chiefly the facility in contenting ourfelves with the more remifs proofs in others, hath been amongit the greateft caufes of detriment and hinderance to De Analogia knowledge. The diftributions and affignations of Demonftra- demonftrations, according to the analogy of fci-
tionum. ences, I note as deficient.

De Augm. The cuftody or retaining of knowledge is either (iii.) Art of in writing or memory; whereof writing hath two cuftody. parts, the nature of the character, and the order (a.) ByWrit- of the entry; for the art of characters, or other vifible notes of words or things, it hath neareft conjugation with grammar; and therefore I refer it to the due place: for the difpofition and collo94 Ariftot. Analyt. Pr. ii. 5. I. 


\section{BOOK II.}

cation of that knowledge which we preferve in writing, it confifteth in a good digeft of commonplaces; wherein I am not ignorant of the prejudice imputed to the ufe of common-place books, as caufing a retardation of reading, and fome floth or relaxation of memory. But becaufe it is but a counterfeit thing in knowledges to be forward and pregnant, except a man be deep and full, I hold the entry of common-places to be a matter of great ufe and effence in ftudying, as that which affureth copie of invention, and contracteth judgment to a ftrength. But this is true, that of the methods of common-places that I have feen, there is none of any fufficient worth; all of them carrying merely the face of a fchool, and not of a world; and referring to vulgar matters and pedantical divifions, without all life or refpect to action.

For the other principal part of the cuftody of knowledge, which is Memory, I find that faculty in my judgment weakly inquired of. An art 95 there is extant of it; but it feemeth to me that there are better precepts than that art, and better practices of that art than thofe received. It is certain the art, as it is, may be raifed to points of oftentation prodigious: but in ufe, as it is now managed, it is barren, (not burdenfome, nor dangerous to natural memory, as is imagined, but barren,) that is, not dexterous to be applied to the ferious ufe of bufinefs and occafions. And there-

$95 \mathrm{Cf}$. Ariftot. De Mem. See the article in the Encycl. Britannica, "On Mnemonics." Cf. Cicero, De Rbet. iii. and De Orat. ii.

(b.) By $\mathrm{Me}$ mory :-ill. handled. The Art of Memory bad. 
fore I make no more eftimation of repeating a great number of names or words upon once hearing, or the pouring forth of a number of verfes or rhymes, ex tempore, or the making of a fatirical fimile of everything, or the turning of everything to a jeft, or the falfifying or contradicting of everything by cavil, or the like, (whereof in the faculties of the mind there is great copie, and fuch as by device and practice may be exalted to an extreme degree of wonder, ) than I do of the tricks of tumblers, funambuloes, baladines: 96 the one being the fame in the mind that the other is in the body, matters of ftrangenefs without worthinefs.

Art of Me- This art of memory is but built upon two mory refts on intentions; the one prenotion, the other emblem. (a.) Preno- Prenotion difchargeth the indefinite ferking of tion ;

(३.) $\mathrm{Em}$ blem. that we would remember, and directeth us to feek in a narrow compafs, that is, fomewhat that hath congruity with our place of memory. Emblem reduceth conceits intellectual to images fenfible, which ftrike the memory more; out of which axioms may be drawn much better practice than that in ufe; and befides which axioms, there are divers moe touching help of memory, not inferior to them. But I did in the beginning diftinguilh, not to report thofe things deficient, which are but only ill managed.

De Augm. There remaineth the fourth kind of rational (iv.) Art of knowledge, which is tranfitive, concerning the Tradition. exprefling or transferring our knowledge to others; 
which I will term by the general name of tradition or delivery. Tradition hath three parts; the firt concerning the organ of tradition: the fecond concerning the method of tradition; and the third concerning the illuftration of tradition.

For the organ of tradition, it is either fpeech or (a.) Its orwriting : for Ariftotle faith well, IVords are the gan; fpeech images of cogitations, and letters are the images of words; 97 but yet it is not of neceffity that cogitations be expreffed by the medium of words. For what oever is capable of fufficient differences, and thofe perceptible by the fenfe, is in nature competent to exprefs cogitations. And therefore we fee in the commerce of barbarous people, that underftand not one another's language, and in the practice of divers that are dumb and deaf, that men's minds are expreffed in geftures, though not exactly, yet to ferve the turn. And we underftand further, that it is the ufe of China, and the kingdoms of the high Levant, ${ }^{98}$ to write in characters real, which exprefs neither letters nor words in grofs, but things or notions; infomuch as countries and provinces, which underitand not one another's language, can neverthelefs read one another's writings, becaufe the characters are accepted more generally than the languages do extend; and therefore they have a vaft multitude of characters, as many, I fuppofe, as radical words.

97 Ariftot. De Interpret. i. 2.

98 "In China et provinciis ultimi Orientis." (De Augm.) See a very interefting note on thefe paragraphs in Ellis and Spedding's ed. of the De Augm, vi. I. 


\section{ADVANCEMENT OF LEARNING.}

Thefe notes of cogitations are of two forts; the one when the note hath fome fimilitude or congruity with the notion: the other ad placitum, having force only by contract or acceptation. Of the former fort are hieroglyphics and geftures. For as to hieroglyphics, things of ancient ufe, and embraced chiefly by the Egyptians, one of the moft ancient nations, they are but as continued impreffes and emblems. And as for geftures, they are as tranfitory hieroglyphics, and are to hieroglyphics as words fpoken are to words written, in that they abide not; but they have evermore, as well as the other, an affinity with the things fignified: as Periander, being confulted with how to preferve a tyranny newly ufurped, bid the meffenger attend and report what he faw him do; and went into his garden and topped all the higheft flowers: fignifying, that it confifted in the cutting off and keeping low of the nobility and grandees.99 Ad placitum, are the characters real before mentioned, and words: although fome have been willing by curious inquiry, or rather by apt feigning to have derived impofition of names from reafon and intendment; a fpeculation elegant, and, by reafon it fearcheth into antiquity, reverent; but iparingly mixed with truth, and of fmall fruit. Do notis re- This portion of knowledge, touching the notes of rum.

93 Ariftot. Polit. iii. I 3, and Herod. v. 92. Cf. alfo Livy, i. 54, where the ftory is transferred to Tarquinius Superbus. Grandees, in ed.1605, grandes; the word being not yet naturalized in the Englifh language. According to Richardfon, Burton (the Anatomy was publinhed in 1624) fpells it grandy. In my copy of the firft edition I have not met with the word. 
things and cogitations in general, I find not inquired, but deficient. And although it may feem of no great ufe, confidering that words and writings by letters do far excel all the other ways; yet becaufe this part concerneth, as it were, the mint of knowledge, (for words are the tokens current and accepted for conceits, as moneys are for values, and that it is fit men be not ignorant that moneys may be of another kind than gold and filver,) I thought good to propound it to better inquiry.

Concerning fpeech and words, the confideration of them hath produced the fcience of grammar: for man ftill ftriveth to reintegrate himfelf in thofe Speech has produced grammar. benedictions, from which by his fault he hath been deprived; and as he hath ftriven againft the firft general curfe by the invention of all other arts, fo hath he fought to come forth of the fecond general curfe, which was the confufion of tongues, by the art of grammar; whereof the ufe in a mother tongue' is fmall, in a foreign tongue more; but moft in fuch foreign tongues as have ceafed to be vulgar tongues, and are turned only to learned tongues. The duty of it is of two natures; the one popular, which is for the fpeedy and perfect attaining languages, as well for intercourfe of fpeech as for underftanding of authors; the other philofophical, examining the power and nature of words, as they are the footiteps and prints of reafon: which kind of analogy between words and reafon is han-

"The Latin is "linguis quibufque vernaculis." Ed. I 605 has in anotber tongue, which is clearly a mirprint-the antithefis lying between a "vernacular" or mother tongue, and a foreign language. 


\section{$210 A D V A N C E M E N T$ OF LEARNING.}

dled $\int$ parfim, brokenly, though not entirely; and therefore I cannot report it deficient, though I think it very worthy to be reduced into' a feience by itfelf.

The accidents of words.

Unto grammar alfo belongeth, as an appendix, the confideration of the accidents of words ; which are meafure, found, and elevation or accent, and the fweetnefs and harlhnefs of them; whence hath iffued fome curious obfervations in rhetoric, but chiefly poefy, as we confider it in refpect of the verfe and not of the argument; wherein though men in learned tongues do tie themfelves to the ancient meafures, yet in modern languages it feemeth to me as free to make new meafures of verfes as of dances : for a dance is a meafured pace, as a verfe is a meafured fpeech. In thefe things the fenfe is better judge than the art;

\section{Coenæ fercula noftræ}

Mallem convivis quam placuifie cocis. ${ }^{2}$

And of the fervile expreffing antiquity in an unlike and an unfit fubject, it is well faid, 2uod tempore antiquum videtur, id incongruitate eft maxime novum. ${ }^{3}$

Ciphers. For ciphers, they are commonly in letters or alphabets, but may be in words. The kinds of ciphers, befides the fimple ciphers, with changes, and intermixtures of nulls and non-fignificants, are many, according to the nature or rule of the infolding, wheel-ciphers, key-ciphers, doubles, \&c. ${ }^{4}$

2 Martial. Epig. ix. 82.

3 This quotation, which is omitted in the Latin, is only another form and application of Bacon's favourite "Antiquitas frculi, juventus mundi."

4 In the Latin a fpecimen of a cipher (invented by himfelf when 
But the virtues of them, whereby they are to be preferred, are three; that they be not laborious to write and read; that they be impoffible to decipher; and, in fome cafes, that they be without fufpicion. The higheft degree whereof is to write omnia per omnia; which is undoubtedly poffible, with a proportion quintuple at moft of the writing infolding to the writing infolded, and no other, reftraint whatfoever. This art of ciphering hath for relative an art of deciphering, by fuppofition unprofitable, but, as things are, of great ufe. For fuppofe that ciphers were well managed, there be multitudes of them which exclude the decipherer. But in regard of the rawnefs and unkilfulnefs of the hands through which they pafs, the greateft matters are many times carried in the weakeft ciphers.

In the enumeration of thefe private and retired Conclufion. arts, it may be thought I feek to make a great mufter-roll of fciences, naming them for how and oftentation, and to little other purpofe. But let thofe which are kilful in them judge whether I bring them in only for appearance, or whether in that which I fpeak of them, though in few marks, there be not fome feed of proficience. And this muft be remembered, that as there be many of great account in their countries and provinces, which, when they come up to the feat of the eftate,

a young man at Paris) is introduced, to thow how the art of writing omnia per omnia can be attained to. See alfo Encycl. Brit. verb. Cipher. Trithemius, Bapt. Porta, and others, wrote treatifes on this art; and it is worth remembering that the Stuarts made confiderable political ufe of it. 


\section{I $2 D V A N C E M E N T$ OF LEARNING.}

are but of mean rank and fcarcely regarded; fo thefe arts, being here placed with the principal and fupreme fciences, feem petty things; yet to fuch as have chofen them to fpend their labours and fudies in them, they feem great matters.

De Aug. vi. For the Method of Tradition, I fee it hath moved 2.

(b.) Method of Tradition. a controverfy in our time. ${ }^{5}$ But as in civil bufinefs, if there be a meeting, and men fall at words, there is commonly an end of the matter for that time, and no proceeding at all; fo in learning, where there is much controverfy, there is many times little inquiry. For this part of knowledge of Method feemeth to me fo weakly inquired as I fhall report it deficient.

Method, a Method hath been placed, and that not amifs, part of Logic. in Logic, as a part of Judgment ; ${ }^{6}$ for as the doctrine of Syllogirms comprehendeth the rules of Judgment upon that which is invented, ro the doctrine of Method containeth the rules of Judgment upon that which is to be delivered; for Judgment precedeth Delivery, as it followeth Invention. Neither is the Method or the nature of the tradition material only to the ufe of knowledge, but likewife to the progreffion of knowledge: for fince the labour and life of one man cannot attain to perfection of knowledge, the wifdom of the tradition is that which infpireth the felicity of con-

5 Between Ramus, whofe method was one of peipetual dichotomies, and others.

${ }^{6}$ Not $f_{0}$ in the ufual text-books-Sanderfon, iii. $30,3 I$, and Aldrich, chap. vi. place it under Difcourfe; and it is defined as "Ratio ita difponendi partes alicujus difciplinæ vel tractationis, ut facillime a nobis integra difcatur." 
tinuance and proceeding. And therefore the moft real diverfity of method, is of Method referred to ufe, and Method referred to progreffion: whereof the one may be termed Magiftral, and the other of Probation.

The latter whereof feemeth to be via deferta et interclufa. For as knowledges are now delivered, there is a kind of contract of error between the Of Proba. tion, or for progreffion deliverer and the receiver: for he that delivereth (deficient.) knowledge, defireth to deliver it in fuch form as may be beft believed, and not as may be beft examined; and he that receiveth knowledge, defireth rather prefent fatisfaction, than expectant inquiry; and fo rather not to doubt, than not to err: glory making the author not to lay open his weaknefs, and floth making the difciple not to know his Atrength.

But knowledge that is delivered as a thread to be fpun on, ought to be delivered and intimated, if it were poffible, in the fame method wherein it was invented : and fo is it poffible of knowledge induced. But in this fame anticipated and prevented knowledge, no man knoweth how he came to the knowledge which he hath obtained. But yet neverthelefs, Jecundum majus et minus, a man may revifit and defcend unto the foundations of his knowledge and confent; and fo tranfplant it into another, as it grew in his own mind. For it is in knowledges as it is in plants: if you mean to ufe the plant, it is no matter for the roots; but if you mean to remove it to grow, then it is more affured to reft upon roots than flips : fo the deli-

Magiftral, or for ufe. 


\section{$214 A D V A N C E M E N T$ OF LEARNING.}

very of knowledges, as it is now ufed, is as of fair bodies of trees without the roots; good for the

De Metbodo fincera, five ad filios fcientiarum.
Enigmatical.
Compared with Aphorifms. carpenter, but not for the planter. But if you will have fciences grow, it is lefs matter for the fhaft or body of the tree, fo you look well to the taking up of the roots : of which kind of delivery the method of the mathematics, in that fubject, hath fome fhadow: but generally I fee it neither put in $u f^{7}$ nor put in inquifition, and therefore note it for deficient.

Another diverfity of Method there is, which hath fome affinity with the former, ufed in fome cafes by the difcretion of the ancients, but difgraced fince by the impoftures of many vain perfons, who have made it as a falfe light for their counterfeit merchandifes; and that is, enigmatical and difclofed. 8 The pretence whereof is, to remove the vulgar capacities from being admitted to the fecrets of knowledges, and to referve them to felected auditors, or wits of fuch tharpnefs as can pierce the veil.

Another diverfity of Method, whereof the confequence is great, is the delivery of knowledge in Aphorifms, or in Methods; wherein we may obferve that it hath been too much taken into cuftom, out of a few axioms or obfervations upon any fubject, to make a folemn and formal art, filling it

II have read ufe for ure. For the Latin is $u f u s$, and the word ure is a rare one. Richardfon's examples are all from Chaucer. The meaning of both words is the fame.

8 Correfponds to the fcholaftic "Methodus ákpoaparıxi et

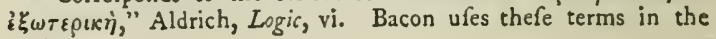
Latin. 
with fome difcourfes, and illuftrating it with examples, and digefting it into a fenfible Method.

But the writing in aphorifms hath many excellent virtues, whereto the writing in Method doth not approach. For firf, it trieth the writer, whether he be fuperficial or folid: for Aphorifms, except they thould be ridiculous, cannot be made but of the pith and heart of fciences; for difcourfe of illuftration is cut off: recitals of examples are cut off; difcourfe of connection and order is cut off; defcriptions of practice are cut off. So there remaineth nothing to fill the Aphorifms but fome good quantity of obfervation: and therefore no man can fuffice, nor in reafon will attempt to write Aphorifms, but he that is found and grounded. But in Methods,

\section{Tantum feries juncturaque pollet, \\ Tantum de medio fumptis accedit honoris; ${ }^{9}$}

as a man hall make a great hew of an art, which, if it were disjointed, would come to little. Secondly, methods are more fit to win confent or belief, but lefs fit to point to action; for they carry a kind of demonfration in orb or circle, one part illuminating another, and therefore fatisfy ; but particulars, being difperfed, do beft agree with difperfed directions. And laftly, A phorifms, reprefenting a knowledge broken, do invite men to inquire farther; whereas Methods, carrying the fhow of a total, do fecure men, as if they were at farthef.

Another diverfity of Method, which is likewife of great weight, is the handling of knowledge by

By affertions and their proofs, or by

${ }^{9}$ Hor. Ep. ad Pis. 242. 


\section{I6 ADVANCEMENT OF LEARNING.}

quertions and anfwers.

affertions and their proofs, or by queftions and their determinations; the latter kind whereof, if it be immoderately followed, is as prejudicial to the proceeding of learning, as it is to the proceeding of an army to go about to befiege every little fort or hold. For if the field be kept, and the fum of the enterprife purfued, thofe fmaller things will come in of themfelves: indeed a man would not leave fome important piece enemy at his back. ${ }^{10}$ In like manner, the ufe of confutation in the delivery of fciences ought to be very fparing; and to ferve to remove ftrong preoccupations and prejudgments, and not to minifter and excite difputations and doubts.

Differs according to fubjectmatter.

Another diverfity of Method is, according to the fubject or matter which is handled; for there is a great difference in delivery of the mathematics, which are moft abftracted of knowledges, and policy, which is the moft immerfed: and howfoever contention hath been moved touching a uniformity of method in multiformity of matter, yet we fee how that opinion, befides the weaknefs of it, hath been of ill defert towards learning, as that which taketh the way to reduce learning to certain empty and barren generalities; being but the very hurks and thells of fciences, all the kernel being forced out and expulfed with the torture and prefs of the Method. And therefore as I did allow well of particular topics for invention, fo I do allow likewife of particular Methods of tradition.

10 This paffage is equivalent to " although indeed a man would not leave fome fortified place hoftile to him in his rear." 
Another diverfity of judgment ${ }^{11}$ in the delivery and teaching of knowledge is according unto the light and prefuppofitions of that which is delivered; for that knowledge which is new, and foreign from According to the knowledge of the receiver. opinions received, is to be delivered in another form than that that is agreeable ${ }^{12}$ and familiar; and therefore Ariftotle, when he thinks to tax Democritus, doth in truth commend him, where he faith, If we Shall indeed difpute, and not follow after fimilitudes, $\mathcal{E}^{\circ} c_{0}{ }^{13}$ For thofe whofe conceits are feated in popular opinions, need only but to prove or difpute; but thofe whofe conceits are beyond popular opinions, have a double labour; the one to make themfelves conceived, and the other to prove and demonftrate : fo that it is of neceffity with them to have recourfe to fimilitudes and tranflations to exprefs themfelves. And therefore in the infancy of learning, and in rude times, when thofe conceits which are now trivial were then new, the world was full of parables and fimilitudes; for elfe would men either have paffed over without mark, or elfe rejected for paradoxes, that which was offered, before they had underftood or judged. So in divine learning, we fee how frequent parables and tropes are: for it is a rule, that whatfoever fcience is not confonant to prefuppofitions, muft pray in aid of fimilitudes.

11 Bacon meant here to fay "diverfity of Method to be ufed with judgment," \&c.; for the Latin is "Sequitur aliud Methodi difcrimen in tradendis fcientijs cum judicio adhibendum."

${ }_{12}$ Agreeable. "Opinionibus jampridem imbibitis et receptis affinis."

13 Arif. Etb. Nic. vi. 3, fee note in Ellis and Spedding's ed. 


\section{I8 ADVANCEMENT OF LEARNING.}

Other dif- There be alfo other diverfities of Methods vulferences.

gar and received: as that of Refolution or Analyfis, of Conftitution or Syftafis, of Concealment or Cryptic, \&c., which I do allow well of, though I have ftood upon thofe which are leaft handled Deprudentia and obferved. All which I have remembered to Traditionis. this purpofe, becaufe I would erect and conftitute one general inquiry, which feems to me deficient, touching the Wifdom of Tradition.

Method But unto this part of knowledge concerning ders the limitation of propofitions. Methods doth farther belong not only the architecture of the whole frame of a work, but alfo the feveral beams and columns thereof; not as to their ftuff, but as to their quantity and figure. And therefore Method confidereth not only the difpofition of the argument or fubject, but likewife the propofitions : not as to their truth or matter, but as to their limitation and manner. For herein Ramus merited better a great deal in reviving the

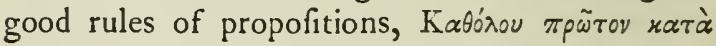
тavтós, \&c., than he did in introducing the canker of epitomes $;^{14}$ and yet (as it is the condition of human things that, according to the ancient fables, the moft precious things bave the moft pernicious keepers ;) it was fo, that the attempt of the one made him fall upon the other. For he had need be well conducted that fhould defign to make axioms convertible, if he make them not withal circular, and non-promovent, or incurring into themfelves; but yet the intention was excellent.

14 Should this not rather have been Dicbotomies? "quam in unica fua Methodo et Dichotomiis obtrudendis," 
The other confiderations of method, concerning propofitions, are chiefly touching the utmoft propofitions, which limit the dimenfions of fciences; for every knowledge may be fitly faid, befides the profundity, (which is the truth and fubftance of it, that makes it folid,) to have a longitude and a latitude; accounting the latitude towards other fciences, and the longitude towards action; that is, from the greateft generality to the moft particular precept. The one giveth rule how far one knowledge ought to intermeddle within the province of another, which is the rule they call $\mathrm{K} \alpha$ a auto ${ }^{15}$ the other giveth rule unto what degree of particularity a knowledge Thould defcend: which latter I find paffed over in filence, being in my judgment the more material; for certainly there muft be fomewhat left to practice; but how much is worthy the inquiry. We fee remote and fuperficial generalities do but offer knowledge to fcorn of practical men; and are no more aiding to practice, than an Ortelius' ${ }^{16}$ univerfal map is to direct the way between London and York. The better fort of rules have been not unfitly compared to glaffes of fteel unpolifhed, where you may fee the images of things, but firt they muft be filed : fo the rules will help, if they be laboured and polifhed by practice. But how cryftalline they may be made at the firft, and how far forth they may be polifhed aforehand, is the queftion; the inquiry whereof feemeth to me deficient.

There hath been alfo laboured and put in prac-

15 Viz. that Propofitions fhould be true effentially.

Method alfo chiefly concerns univerfal propofitions. 
that of Ray- tice a method, which is not a lawful method, but mond Lully. a method of impofture; which is, to deliver knowledges in fuch manner, as men may fpeedily come to make a fhow of learning who have it not: fuch was the travail of Raymundus Lullius, in making that art which bears his name $:^{17}$ not unlike to fome books of typocofmy, which have been made fince; being nothing but a mafs of words of all arts, to give men countenance, that thofe which ufe the terms might be thought to underftand the art; which collections are much like a fripper's or broker's hop, that hath ends of everything, but nothing of worth.

De Aug. vi. 2.

(c.) Illuftration of tradition, or rhetoric.

Now we defcend to that part which concerneth the illuftration of tradition, comprehended in that fcience which we call rbetoric, or art of eloquence; a fcience excellent, and excellently well laboured. For though in true value it is inferior to wifdom, (as it is faid by God to Mofes, when he difabled himfelf for want of this faculty, Aaron Shall be thy speaker, and thou fhalt be to him as God:) ${ }^{18}$ yet with people it is the more mighty: fo Salomon faith, Sapiens corde appellabitur prudens, fed dulcis eloquio majora reperiet; ${ }^{19}$ fignifying, that profoundnefs of wifdom will help a man to a name or admiration, but that it is eloquence that prevaileth in an active life. And as to the labouring of it,

17 Raymundus Lully, "the Enlightened Doctor," was born in Majorca in 1225, ftudied Arabian philofophy, chemiftry, phyfic, and divinity. He was ftoned to death, at the age of 80 , in Mauretania, for preaching the gofpel. For a brief account of his Method, fee note to Ellis and Spedding's De Augm. vi. 2. (p. 66.)

18 Exod. iv. 16.

19 Prov. xvi. 21. 
the emulation of Ariftotle with the rhetoricians of his time, and the experience of Cicero, hath made them in their works of rhetorics exceed themfelves. Again, the excellency of examples of eloquence in the orations of Demolthenes and Cicero, added to the perfection of the precepts of eloquence, hath doubled the progreffion in this art; and therefore the deficiencies which I thall note will rather be in fome collections, which may as hand-maids attend the art, than in the rules or ufe of the art itfelf.

Notwithftanding, to ftir the earth a little about the roots of this fcience, as we have done of the Definition reft; the duty and office of rhetoric is, to apply reafon to imagination for the better moving of the will. For we fee reafon is difturbed in the adminiftration thereof by three means; by illaqueation or fophifm, which pertains to logic; by imagination or impreffion, which pertains to rhetoric; and by paffion or affection, which pertains to morality. And as in negotiation with others, men are wrought by cunning, by importunity, and by vehemency; fo in this negotiation within ourfelves, men are undermined by inconfequences, folicited and importuned by impreffions or obfervations, and tranfported by paffions. Neither is the nature of man fo unfortunately built, as that thofe powers and arts hould have force to difturb reafon, and not to eftablifh and advance it. For the end of logic is, to teach a form of argument to fecure reafon, and not to entrap it; the end of . morality is to procure the affections to obey reafon, 


\section{ADVANCEMENT OF LEARNING.}

and not to invade it ; the end of rhetoric is, to fill the imagination to fecond reafon, and not to opprefs it: for thefe abufes of art come in but ex obliquo, for caution.

Plato un- And therefore it was great injuftice in Plato, derrated it. though fpringing out of a juft hatred to the rhetoricians of his time, to efteem of rhetoric but as a voluptuary art, refembling it to cookery, that did mar wholefome meats, and help unwholefome by variety of fauces to the pleafure of the tafte..$^{20}$ For we fee that fpeech is much more converfant in adorning that which is good, than in colouring that which is evil; for there is no man but fpeaketh more honeftly than he can do or think: and it was excellently noted by Thucydides in Cleon, that becaufe he ufed to hold on the bad fide in caufes of eftate, therefore he was ever inveighing againft eloquence and good fpeech $;^{21}$ knowing that no man can fpeak fair of courfes fordid and bafe. And therefore as Plato faid elegantly, That virtue, if he could be feen, would move great love and affection; ; fo feeing that the cannot be fhowed to the fenfe by corporal thape, the next degree is to fhow her to the imagination in lively reprefentation: for to thow her to reafon only in fubtilty of argument, was a thing ever derided in Chryfippus and many of the Stoics; who thought to thruft virtue upon men by fharp difputations and conclufions, which have no fympathy with the will of man.

20 Plat. Gorg. $4{ }_{32}^{62}$, feq. Plat. Phadr. 250.
${ }^{21}$ Thucyd. iii. 42. 
Again, if the affections in themfelves were pliant and obedient to reafon, it were true there fhould be no great ure of perfuafions and infinuations to the will, more than of naked propofition and Ufeful to quell the feditions of the parfions. proofs; but in regard of the continual mutinies and feditions of the affections,

\section{Deteriora fequor: ${ }^{23}$ \\ Video meliora, proboque;}

reafon would become captive and fervile, if eloquence of perfuafions did not practife and win the imagination from the affections' part, and contract a confederacy between the reafon and imagination againft the affections; for the affections themfelves carry ever an appetite to good, as reafon doth. The difference is, that the affection beholdeth merely the prefent; reafon beholdeth the future and fum of time. And therefore the prefent filling the imagination more, reafon is commonly vanquifhed; but after that force of eloquence and perfuafion hath made things future and remote appear as prefent, then upon the revolt of the imagination reafon prevaileth.

We conclude, therefore, that rhetoric can be no more charged with the colouring of the worfe part, than logic with fophiftry, ${ }^{2+}$ or morality with vice. For we know the doctrines of contraries are the fame, though the ufe be oppofite. It appeareth alfo that logic differeth from rhetoric, not only as the fift from the palm, the one clofe, the other at large; but much more in this, that logic handleth reafon exact and in truth, and rhetoric handleth

Rhetoric by the fide of logic.

${ }^{23}$ Ovid, Metam. vii. 20.

${ }^{24}$ Arift. Rhet. I. i. I4. 


\section{ADVANCEMENT OF LEARNING.}

it as it is planted in popular opinions and manners. And therefore Ariftotle ${ }^{25}$ doth wifely place rhetoric as between logic on the one fide, and moral or civil knowledge on the other, as participating of both: for the proofs and demonftrations of logic are towards all men indifferent and the fame; but the proofs and perfuafions of rhetoric ought to differ according to the auditors:

Orpheus in fylvis, inter delphinas Arion. ${ }^{26}$

Which application, in perfection of idea, ought to extend fo far, that if a man thould fpeak of the fame thing to feveral perfons, he hould fpeak to them all refpectively and feveral ways: though this politic part of eloquence in private fpeech it is eafy for the greateft orators to want: whilf by the obferving their well-graced forms of fpeech

De prudentia fermonis privati.

Its deficiences: no good collection of $\mathrm{co}-$ lours of good and evil. they leefe the volubility of application: and therefore it thall not be amifs to recommend this to better inquiry, not being curious whether we place it here, or in that part which concerneth policy.

Now therefore will I defcend to the deficiences, which, as I faid, are but attendances $:^{27}$ and firft, I do not find the wifdom and diligence of Ariftotle well purfued, who began to make a collection of the popular figns and colours of good and evil, both fimple and comparative, which are as the fophifms of rhetoric, as I touched before. ${ }^{98}$ For example :

25 Ariftot. Rbet. i. 2. 7.

26 Virg. Ecl. viii. 56.

27 Attendances. "Pertinent omnia ad promptuarium."

28 Thefe were publithed in 1597 , at the end of the volume of Effays. They are reproduced in the correfponding place of the Latin. See Arif. Top. i. 12. 
Sophifma.

Quod laudatur, bonum : quod vituperatur, malum.

Redargutio.

Laudat venales qui vult extrudere merces. ${ }^{29}$

Malum ef, malum eft, inquit emptor: fed cum recelferit, tum gloriabitur! ${ }^{30}$

The defects in the labour of Ariftotle are three: one, that there be but a few of many; another, that their elenches are not annexed; and the third, that he conceived but a part of the ufe of them: for their ufe is not only in probation, but much more in impreffion. For many forms are equal in fignification which are differing in impreffion; as the difference is great in the piercing of that which is Tharp and that which is flat, though the ftrength of the percuffion be the fame: for there is no man but will be a little more raifed by hearing it faid, Your enemies will be glad of this:

Hoc Ithacus velit, et magno mercentur Atridæ : ${ }^{31}$

than by hearing it faid only, $\mathcal{T}$ bis is evil for you.

Secondly, I do refume alfo that which I mentioned before, touching provifion or preparatory ftore for the furniture of fpeech and readinefs of ula. invention; which appeareth to be of two forts; the one in refemblance to a hop of pieces unmade up, the other to a hop of things ready made up ; both to be applied to that which is frequent and moft in requeft: the former of thefe I will call antitheta, and the latter formule.

Antitheta are the es argued pro et contra; wherein

29 Hor. Ep. ii. 2. I I.

30 Prov. xx. 14.

31 Virg. An. ii. 104.

Deficient in antitheta and form- 


\section{ADVANCEMENT OF LEARNING.}

men may be more large and laborious: but, in fuch as are able to do it, to avoid prolixity of entry, I win the feeds of the feveral arguments to be caft up into fome brief and acute fentences, not to be cited, but to be as fkeins or bottoms of thread, to be unwinded at large when they come to be ufed; fupplying authorities and examples by reference.

\section{Proverbis legis.}

Non eft interpretatio, fed divinatio, qua recedit a litera :

Cum receditur a litera, judex tranfit in legiflatorem.

\section{Pro fententia legis.}

Ex omnibus verbis eft eliciendus fenfus qui interpretatur fingula.

Formule are but decent and apt paffages or conveyances of fpeech, which may ferve indifferently for differing fubjects; as of preface, conclufion, digrefion, tranfition, excufation, Ec. For as in buildings, there is great pleafure and ufe in the well cafting of the ftaircafes, entries, doors, windows, and the like; fo in fpeech, the conveyances and paffages are of fpecial ornament and effect.

\section{$A$ conclufion in a deliberative.}

So may we redeem the faults paffed, and prevent the inconveniences future.

Appendices to the art of tradition.

(a.) Advice to critics.
There remain two appendices touching the tradition of knowledge, the one critical, the other pedantical. For all knowledge is either delivered by teachers, or attained by men's proper endeavours: and therefore as the principal part of tradition of knowledge concerneth chiefly writing of books, fo the relative part thereof concerneth reading of books ; whereunto appertain incidently thefe confiderations. The firft is concerning the true 
correction and edition of authors; wherein neverthelefs rafh diligence hath done great prejudice. For thefe critics have often prefumed, that that which they underftand not is falfe fet down: as the prieft that, where he found it written of St. Paul, Demiffus eft per fportam ${ }^{32}$ mended his book, and made it Demiffus eft per portam; becaufe sporta was a hard word, and out of his reading: and furely their errors, though they be not fo palpable and ridiculous, are yet of the fame kind. And therefore, as it hath been wifely noted, the moft corrected copies are commonly the leaft. correct.

The fecond is concerning the expofition and explication of authors, which refteth in annotations and commentaries: wherein it is over ufual to blanch the obfcure places, and difcourfe upon the plain.

The third is concerning the times, which in many cafes give great light to true interpretations.

The fourth is concerning fome brief cenfure and judgment of the authors; that men thereby may make fome election unto themfelves what books to read.

And the fifth is concerning the fyntax and difpofition of ftudies; that men may know in what order or purfuit to read.

For pedantical knowledge, it containeth that ( $\beta$.) Of pedifference of tradition which is proper for youth; dantical whereunto appertain divers confiderations of great (i.e. wifdom fruit. 


\section{ADVANCEMENT OF LEARNING.}

As firft, the timing and feafoning of knowledges; as with what to initiate them, and from what for a time to refrain them.

Secondly, the confideration where to begin with the eafieft, and fo proceed to the more difficult; and in what courfes to prefs the more difficult, and then to turn them to the more eafy: for it is one method to practife fwimming with bladders, and another to practife dancing with heavy hoes.

A third is the application of learning according unto the propriety of the wits; for there is no defect in the faculties intellectual, but feemeth to have a proper cure contained in fome ftudies: as, for example, if a child be bird-witted, that is, hath not the faculty of attention, the mathematics giveth a remedy thereunto; for in them, if the wit be caught away but a moment, one is to begin anew. And as fciences have a propriety towards faculties for cure and help, fo faculties or powers have a fympathy towards fciences for excellency or fpeedy profiting: and therefore it is an inquiry of great wifdom, what kinds of wits and natures are molt apt and proper for what feiences.

Fourthly, the ordering of exercifes is matter of great confequence to hurt or help: for, as is well obferved by Cicero, ${ }^{33}$ men in exercifing their faculties, if they be not well advifed, do exercife their faults and get ill habits as well as good; fo there is a great judgment to be had in the continuance and intermifion of exercifes. It were too long to particularize a number of other confidera- 


\section{BOOK II.}

tions of this nature, things but of mean appearance, but of fingular efficacy. For as the wronging or cherifhing of feeds or young plants is that that is molt important to their thriving: (and as it was noted that the firt fix kings being in truth as tutors of the ftate of Rome in the infancy thereof, was the principal caufe of the immenfe greatnefs of that ftate which followed:) fo the culture and manurance of minds in youth, hath fuch a forcible, though unfeen operation, as hardly any length of time or contention of labour can countervail it afterwards. And it is not amifs to oblerve alfo how fmall and mean faculties gotten by education, yet when they fall into great men or great matters, do work great and important effects; whereof we fee a notable example in Tacitus ${ }^{3+}$ of two ftage players, Percennius and Vibulenus, who by their faculty of playing put the Pannonian armies into an extreme tumult and combuftion. For there arifing a mutiny amongft them upon the death of Auguftus Cæfar, Blæfus the lieutenant had committed fome of the mutineers, which were fuddenly refcued; whereupon Vibulenus got to be heard fpeak, which he did in this manner:The e p poor innocent wretches appointed to cruel death, you bave reftored to bebold the light; but who fhall reftore my brother to me, or life unto my brotber, that was fent bither in meffage from the legions of Germany, to treat of the common caufe? and he hath murdered bim this laft night by fome of bis fencers and ruffians, that be hatb about bim for bis execu-

34 Tacit. Ann. i. 22, 23. 


\section{ADVANCEMENT OF LEARNING.}

tioners upon foldiers. Anfwer, Blafus, what is done with bis body? The mortalef enemies do not deny burial. When I have performed my laft duty to the corpse with kifes, with tears, command me to be flain befide bim; fo that thefe my fellows, for our good meaning, and our true bearts to the legions, may have leave to bury us. With which fpeech he put the army into an infirite fury and uproar: whereas truth was he had no brother, neither was there any fuch matter; but he played it merely as if he had been upon the ftage.

But to return: we are now come to a period of rational knowledges; wherein if I have made the divifions other than thofe that are received, yet would I not be thought to difallow all thofe divifions which I do not ufe. For there is a double neceffity impofed upon me of altering the divifions. The one, becaufe it differeth in end and purpofe, to fort together thofe things which are next in nature, and thofe things which are next in ufe. For if a fecretary of ftate fhould fort his papers, it is like in his ftudy or general cabinet he would fort together things of a nature, as treaties, inftructions, \&cc, but in his boxes or particular cabinet he would fort together thofe that he were like to ufe together, though of feveral natures; fo in this general cabinet of knowledge it was neceffary for me to follow the divifions of the nature of things; whereas if myfelf had been to handle any particular knowledge, I would have refpected the divifions fitteft for ufe. The other, becaufe the bringing in of the deficiences did by confequence 
alter the partitions of the reft. For let the knowledge extant, for demonftration fake, be fifteen; let the knowledge with the deficiences be twenty; the parts of fifteen are not the parts of twenty; for the parts of fifteen are three and five; the parts of twenty are two, four, five, and ten. So as thefe things are without contradiction, and could not otherwife be.

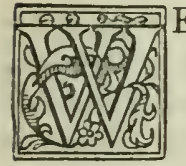

E proceed now to that knowledge which confidereth of the appetite and will of man: whereof Salomon faith, Ante omnia, fili, cuftodi cor tuum; nam inde procedunt aftiones vita. ${ }^{35}$ In the handling of this fcience, thofe which have written feem to me to have done as if a man, that profeffed to teach to write, did only exhibit fair copies of alphabets De Aug. viI. I. (B.) The Moral functions of the Mind; i.e. of the Ap. petite and Will of men. Ill handled and letters joined, without giving any precepts or directions for the carriage of the hand and framing of the letters. So have they made good and fair exemplars and copies, carrying the draughts and portraitures of good, virtue, duty, felicity; propounding them well defcribed as the true objects and fcopes of man's will and defires. But how to attain thefe excellent marks, and how to frame and fubdue the will of man to become true and conformable to thefe purfuits, they pals it over altogether, or Aightly and unprofitably. For it is not the difputing that moral virtues are in the mind of man by habit and not by nature, ${ }^{36}$ or the

35 Prov. iv. 23.

${ }^{36}$ Arift. Eth. Nic. ii. I. Eud. Eth. i. 3. 1. 
232 ADVANCEMENT OF LEARNING.

diftinguifhing that generous fpirits are won by doctrines and perfuafions, and the vulgar fort by reward and punifhment, and the like fcattered glances and touches, that can excufe the abfence of this part.

Formen defpife it as common.

The reafon of this omiffion I fuppofe to be that hidden rock whereupon both this and many other barks of knowledge have been caft away; which is, that men have defpifed to be converfant in ordinary and common matters, the judicious direction whereof neverthelefs is the wifelt doctrine, (for life confifteth not in novelties or fubtilties,) but contrariwife they have compounded fciences chiefly of a certain refplendent or luftrous mafs of matter, chofen to give glory either to the fubtilty of difputations, or to the eloquence of difcourfes. But Seneca giveth an excellent check to eloquence; Nocet illis eloquentia, quibus non rerum cupiditatem facit, fed fui. ${ }^{37}$ Doctrine fhould be fuch as thould make men in love with the leffon, and not with the teacher ; being directed to the auditor's benefit, and not to the author's commendation. And therefore thofe are of the right kind which may be concluded as Demofthenes concludes his counfel, Que fi feceritis, non oratorem duntaxat in preSentia laudabitis, $\int e d$ vofmetipfos etiam non ita multo poft fatu rerum veftrarum meliore. ${ }^{38}$

Neither needed men of fo excellent parts to have defpaired of a fortune, which the poet Virgil promifed himfelf, and indeed obtained, who got as

${ }^{38}$ Demofth. Olyntb. B. ad fin. 
much glory of eloquence, wit, and learning in the expreffing of the obfervations of hubandry, as of the heroical acts of Æneas :-

Nec fum animi dubius, verbis ea vincere magnum

Quam fit, et anguftis his addere rebus honorem. ${ }^{39}$

And furely, if the purpole be in good earneft, not to write at leifure that which men may read at leifure, but really to inftruct and fuborn action and active life, thefe Georgics of the mind, concerning the hufbandry and tillage thereof, are no lefs worthy than the heroical defcriptions of virtue, duty, and felicity. Wherefore the main and primitive divifion of moral knowledge feemeth to be into the exemplar or platform of good, and the regiment or culture of the mind : the one defcribing the nature of good, the other prefcribing rules how to fubdue, apply, and accommodate the will of man thereunto.

The doctrine touching the platform or nature of good confidereth it either fimple or compared; either the kinds of good, or the degrees of good; in the latter whereof thofe infinite difputations, which were touching the fupreme degree thereof, which they term felicity, beatitude, or the higheft good, the doctrines concerning which were as the heathen divinity, ${ }^{40}$ are by the Chriftian faith difcharged. And as Ariftotle faith, That young men may be bappy, but not otherwife but by bope ; ${ }^{41}$ fo we muft all acknowledge our minority, and em-

(i.) Of the nature of Good.

Objects of Ethics. (i.) The nature of Good. (ii.) Moral culture.

39 Gearg. iii. 289 .

40 i.e. Stood to the Heathen in the place of Divinity. "Quæ ethnicis inftar Theologiæ erant."

4 Rbet. ii. 12.8. 


\section{$234 A D V A N C E M E N T$ OF LEARNING.}

brace the felicity which is by hope of the future world.

We may omit the Summum Bonum, (as belonging to the future life.)

Freed therefore and delivered from this doctrine of the philofopher's heaven, whereby they feigned a higher elevation of man's nature than was, (for we fee in what a height of ftyle Seneca writeth, Vere magnum, babere fragilitatem bominis, securitatem $D_{e i,{ }^{4}}$ ) we may with more fobriety and truth receive the reft of their inquiries and labours. Wherein for the nature of good pofitive or fimple, they have fet it down excellently, in defcribing the forms of virtue and duty, with their fituations and poftures; in diftributing them into their kinds, parts, provinces, actions, and adminiftrations, and the like: nay farther, they have commended them to man's nature and fpirit, with great quicknefs of argument and beauty of perfuafions ; yea, and fortified and entrenched them, as much as difcourfe can do, againft corrupt and popular opinions. Again, for the degrees and comparative nature of good, they have alfo excellently handled it in their triplicity of good, in the comparifon between a contemplative and an active life, ${ }^{43}$ in the diftinction between virtue with reluctation and virtue fecured, in their encounters between honefty and profit, in their balancing of virtue with virtue, and the like; fo as this part deferveth to be reported for excellently laboured.

Notwithftanding, if before they had come to the popular and received notions of virtue and vice, pleafure and pain, and the reft, they had ftayed a

12 Sen. ad Lucilium, Ep. 53.

43 Arift, Eth. Nic, x. 6-8. 
little longer upon the inquiry concerning the roots of good and evil, and the ftrings of thofe roots, they had given, in my opinion, a great light to that which followed; and fpecially if they had confulted with nature, they had made their doctrines lefs prolix and more profound; which being by them in part omitted and in part handled with much confufion, we will endeavour to refume and open in a more clear manner.

There is formed in every thing a double nature of good: the one, as every thing is a total or fubftantive in itfelf; the other, as it is a part or member of a greater body; whereof the latter is in Good either (I.) Private, or (2.) Reladegree the greater and the worthier, becaufe it tendeth to the confervation of a more general form. Therefore we fee the iron in particular fympathy moveth to the lodeftone; but yet if it exceed a certain quantity, it forfaketh the affection to the lodeftone, and like a good patriot moveth to the earth, which is the region and country of mafly bodies: fo may we go forward, and fee that water and mafty bodies move to the centre of the earth; but rather than to fuffer a divulfion in the continuance of nature, they will move upwards from the centre of the earth, forfaking their duty to the earth in regard to their duty to the world. This double nature of good, and the comparative thereof, is much more engraven upon man, if he degenerate not: unto whom the confervation of duty to the public ought to be much more precious than the confervation of life and being: according to that memorable fpeech of Pompeius Magnus, when 


\section{ADVANCEMENT OF LEARNING.}

being in commiffion of purveyance for a famine at Rome, and being diffuaded with great vehemency and inftance by his friends about him that he fhould not hazard himfelf to fea in an extremity of weather, he faid only to them, Necefje eft ut eam, Chriftianity non ut vivam. ${ }^{4+}$ But it may be truly affirmed that exalts relative (or focial) good. there was never any philofophy, religion, or other difcipline, which did fo plainly and highly exalt the good which is communicative, and deprefs the good which is private and particular, as the Holy Faith; well declaring that it was the fame God that gave the Chriftian law to men, who gave thofe laws of nature to inanimate creatures that we fpoke of before; for we read that the elected faints of God have wifhed themfelves anathematized and razed out of the book of life, in an ecttafy of charity and infinite feeling of communion. 45

This being fet down and ftrongly planted, doth judge and determine moft of the controverfies This con- wherein moral philofophy is converfant. For firft, - demns Arifit decideth the queftion touching the preferment tutle's contemplative perfection of Life. of the contemplative or active life, and decideth it againft Ariftotle. For all the reafons which he bringeth for the contemplative are private, and refpecting the pleafure and dignity of a man's felf, (in which refpects, no queftion, the contemplative life hath the pre-eminence) not much unlike to that comparifon, which Pythagoras made for the gracing and magnifying of philofophy and contemplation: who being alked what he was, an- 
fwered, That if Hiero were ever at the Olympian games, be knew the manner, that fome came to try their fortune for the prizes, and fome came as merchants to utter their commodities, and fome came to make good cheer and meet their friends, and fome came to look on; and that be was one of them that came to look on. ${ }^{46}$ But men muft know, that in this theatre of man's life it is referved only for God and angels to be lookers on : neither could the like queftion ever have been received in the church (notwithftanding their Pretiofa in oculis Domini mors fanctorum ejus, ${ }^{\text {î }}$ by which place they would exalt their civil death and regular profeffions, ) but upon this defence, that the monaftical life is not fimply ${ }^{48}$ contemplative, but performeth the duty either of inceffant prayers and fupplications, which hath been truly efteemed as an office in the church, or elfe of writing or taking inftructions for writing concerning the law of God, as Mofes did when he abode fo long in the mount. ${ }^{49}$ And fo we fee Enoch the feventh from Adam, who was the firft contemplative, and walked with God, yet did alfo endow the church with prophecy, which St. Jude citeth. ${ }^{50}$ But for contemplation which hould be finifhed in itfelf, without cafting beams upon fociety, affuredly divinity knoweth it not.

It decideth alfo the controverfies between Zeno and Socrates, and their fchools and fucceffions, on

It decides the quarrel

46 Cic. Tufc. Quaft. v. 3. of Leo, tyrant of Phlius, not of Hiero.

47 Ps. cxvi. $x 5$.

43 Ex. xxiv.

48 Ed. 1605 , fimple; $1629,163 \hat{3}$, fimply.

50 Jude 14 . 
between the one fide, who placed felicity in virtue fimply Stoics and Epicureans, \&c., as to the sature of felicity.

or attended, the actions and exercifes whereof do chiefly embrace and concern fociety; and on the other fide, the Cyrenaics and Epicureans, who placed it in pleafure, and made virtue, (as it is ufed in fome comedies of errors, wherein the miftrefs and the maid change habits, ) to be but as a fervant, without which pleafure cannot be ferved and attended, and the reformed fchool of the Epicureans, which placed it in ferenity of mind and freedom from perturbation, (as if they would have depofed Jupiter again, and reftored Saturn and the firt age, when there was no fummer nor winter, fpring nor autumn, but all after one air and feafon,) and Herillus, who placed felicity in extinguifhment of the difputes of the mind, making no fixed nature of good and evil, efteeming things according to the clearnefs of the defires, or the reluctation; which opinion was revived in the herefy of the Anabaptifts, ${ }^{51}$ meafuring things according to the motions of the fpirit, and the conftancy or wavering of belief: all which are manifeft to tend to private repofe and contentment, and not to point of fociety.

Cenfures It cenfureth alfo the philofophy of Epictetus, Epictetus. which prefuppofeth that felicity muft be placed in thofe things which are in our power, left we be liable to fortune and difturbance: as if it were not a thing much more happy to fail in good and vir-

51 Anabaptifts. Bacon here refers to the doctrines held by the German Anabaptifts. They believed themfelves to be under fpecial and divine influences, and therefore had no need of magiftracies, of diftinct ranks of men, or of reftrictions in marriage. 
tuous ends for the public, than to obtain all that we can wifh to ourfelves in our proper fortune; as Gonfalvo faid to his foldiers, fhowing them Naples, and protefting, $\mathrm{He}$ bad ratber die one foot forwards, than to have bis life fecured for long by one foot of retreat. ${ }^{52}$ Whereunto the wifdom of that heavenly leader hath figned, who hath affirmed that a good confcience is a continual feaft; ${ }^{53}$ fhowing plainly that the confcience of good intentions, howfoever fucceeding, is a more continual joy to nature, than all the provifion which can be made for fecurity and repofe.

It cenfureth likewife that abufe of philofophy, which grew general about the time of Epictetus, in converting it into an occupation or profeffion; as if the purpofe had been, not to refift and extinguifh perturbations, but to fly and avoid the And the error of making a profeffion of Philofophy. caufes of them, and to thape a particular kind and courfe of life to that end; introducing fuch a health of mind, as was that health of body of which Ariftotle fpeaketh of Herodicus, who did nothing all his life long but intend his health $:^{5+}$ whereas if men refer themfelves to duties of fociety, as that health of body is beft, which is ableft to endure all alterations and extremities; fo likewife that health of mind is moft proper, which can go through the greateft temptations and perturbations. So as Diogenes' opinion is to be accepted, who commended not them which abftained, but them which fuftained, and could refrain their mind

52 Guicciardini, vi. 2.

54 Arift. Rhet. i. 5. 10.

53 Prov. Xv. 15. 


\section{ADVANCEMENT OF LEARNING.}

in pracipitio, and could give unto the mind, as is ufed in horfemanthip, the fhorteft ftop or turn. ${ }^{55}$

And with- Laftly, it cenfureth the tendernefs and want of drawal from bufine?s.

application in fome of the moft ancient and reverend philofophers and philofophical men, that did retire too eafily from civil bufinefs, for avoiding of indignities and perturbations: whereas the refolution of men truly moral ought to be fuch as the fame Gonfalvo faid the honour of a foldier fhould be, e telâ craffiore, and not fo fine as that every thing thould catch in it and endanger it.

De Aug. To refume private or particular good; it falleth vili. 2.

(I.) Private good, either (a.) Active, or

(b.) Paffive. into the divifion of good active and pafjive: for this difference of good, not unlike to that which amongt the Romans was exprefled in the familiar or houfehold terms of promus and condus, is formed alfo in all things, and is beft difclofed in the two feveral appetites in creatures; the one to preferve or continue themfelves, and the other to dilate or multiply themfelves; whereof the latter feemeth to be the worthier: for in nature the heavens, which are the more worthy, are the agent; and the earth, which is the lefs worthy, is the patient.

(a.) Active. In the pleafures of living creatures, that of generation is greater than that of food; in divine doctrine, beatius eft dare quam accipere, ${ }^{56}$ and in life, there is no man's fpirit fo foft, but efteemeth the effecting of fomewhat that he hath fixed in his defire, more than fenfuality; which priority of the active good, is much upheld by the confi-

"s Diog. Laert. Vita Diogenis, fee Ellis and Spedding's ed. in loco.

so Acts $x \times .35$. 
deration of our eftate to be mortal and expofed to fortune. For if we might have a perpetuity and certainty in our pleafures, the ftate of them would advance their price: but when we fee it is but magni refimamus mori tardius, ${ }^{57}$ and ne glorieris de.craftino, nefcis partum diei, ${ }^{58}$ it maketh us to defire to have fomewhat fecured and exempted from time; which are only our deeds and works : as it is faid opera corum fequuntur $\cos ^{59}$ The preeminence likewife of this active good is upheld by the affection which is natural in man towards variety and proceeding; which in the pleafures of the fenfe, which is the principal part of paffive good, can have no great latitude: Cogita quamdiu eadem feceris; cibus, fomnus, ludus; per bunc circulum curritur; mori velle non tantum fortis, aut mifer, aut prudens, fed etiam faftidiofus poteft. ${ }^{60}$ But in enterprifes, purfuits, and purpofes of life, there is much variety; whereof men are fenfible with pleafure in their inceptions, progreffions, recoils, reintegrations, approaches and attainings to their ends : fo as it was well faid Vita fine propofito languida et vaga eft. ${ }^{61}$ Neither hath this active good any identity with the good of fociety, though in fome cafe it hath an incidence into it ; for although it do many times bring forth acts of beneficence, yet it is with a refpect private to a man's own power, glory, amplification, continuance; as ap-

57 Sen. Nat. Quaft. ii. 59.

59 Revel. xiv. I3.

58 Prov. xxvii. $\mathrm{r}$.

60 Sen. ad Lucil. Epift. 77.

${ }^{11}$ Sen. ad Lucil. Epift. 95, where the words "languida et" are wanting. 


\section{$242 A D V A N C E M E N T$ OF LEARNING.}

peareth plainly, when it findeth a contrary fubject. For that gigantine ftate of mind which poffeffeth the troublers of the world, fuch as was Lucius Sylla, and infinite other in finaller model, who would have all men happy or unhappy as they were their friends or enemies, and would give form to the world, according to their own humours, (which is the true Theomachy,) pretendeth and afpireth to active good, though it recedeth fartheft from good of fociety, which we have determined to be the greater.

(b.) Paffive. Either (a) Confervative, or (B.) Perfective.

To refume paflive good, it receiveth a fubdivifion of confervative and perfective. For let us take a brief review of that which we have faid: we have fpoken firft of the good of fociety, the intention whereof embraceth the form of human nature, whereof we are members and portions, and not our own proper and individual form: we have fpoken of active good, and fuppofed it as a part of private and particular good: and rightly, for there is impreffed upon all things a triple defire or appetite proceeding from love to themfelves; one of preferving and continuing their form; another of advancing and perfecting their form; and a third of multiplying and extending their form upon other things; whereof the multiplying, or fignature of it upon other things, is that which we handled by the name of active good. So as there remaineth the conferving of it, and perfecting or raifing of it ; which latter is the higheft degree of paffive good. For to preferve in 
ftate is the lefs, to preferve with advancement is the greater. So in man,-

( $\beta$.$) Periec-$ tive.

Igneus eft ollis vigor, et cæieftis origo. ${ }^{6 \cdot 2}$

His approach or affumption to divine or angelical nature is the perfection of his form; the error or falfe imitation of which good is that which is the tempert of human life; while man, upon the inftinct of an advancement formal and effential, is carried to feek an advancement local. For as thofe which are fick, and find no remedy, do tumble up and down and change place, as if by a remove local they could obtain a remove internal; fo is it with men in ambition, when failing of the means to exalt their nature, they are in a perpetual eftuation to exalt their place. So then paffive good is, as was faid, either confervative or perfective.

To refume the good of confervation or comfort, which confifteth in the fruition of that which is (a.) Conferagreeable to our natures; it feemeth to be the moft pure and natural of pleafures, but yet the fofteft and the loweft. And this alfo receiveth a difference, which hath neither been well judged of, nor well inquired: for the good of fruition or contentment is placed either in the fincerenefs of the fruition, or in the quicknefs and vigour of it; the one fuperinduced by equality, the other by viciffitude ; the one having lefs mixture of evil, the other more impreffion of good. Which of thefe is the greater good is a queftion controverted; but whether man's nature may not be capable of both, is a queftion not inquired.

62 Virg. $E_{\text {n. vi. } 730 .}$ 


\section{ADVANCEMENT OF LEARNING.}

The former queftion being debated between Socrates and a fophift, Socrates placing felicity in an equal and conftant peace of mind, and the fophift in much defiring and much enjoying, they fell from argument to ill words : the fophift faying that Socrates' felicity was the felicity of a block or ftone; and Socrates faying that the fophift's felicity was the felicity of one that had the itch, who did nothing but itch and fcratch. ${ }^{63}$ And both thefe opinions do not want their fupports. For the opinion of Socrates is much upheld by the general confent even of the Epicures themfelves, that virtue beareth a great part in felicity; and if fo, certain it is, that virtue hath more ufe in clearing perturbations than in compaffing defires. The fophift's opinion is much favoured by the affertion we laft fpoke of, that good of advancement is greater than good of fimple prefervation; becaufe every obtaining a defire hath a thow of advancement, as motion though in a circle hath a fhow of progreffion.

But the fecond queftion, decided the true way, maketh the former fuperfluous. For can it be doubted but that there are fome who take more pleafure in enjoying pleafures than fome other, and yet neverthelefs are lefs troubled with the lofs or leaving of them? lo as this fame, Non uti ut non appetas, non appetere ut non metuas, funt animi pufilli et diffidentis. And it feemeth to me, that moft of the doctrines of the philofophers are more fearful and cautionary than the nature of things re- 


\section{BOOK II.}

quireth. So have they increafed the fear of death in offering to cure it. For when they would lave a man's whole life to be but a difcipline or preparation to die, they muft needs make men think that it is a terrible enemy, againft whom there is no end of preparing. Better faith the poet :-

Qui fpatium vitæ extremum inter munera ponat Naturæ. ${ }^{64}$

So have they fought to make men's minds too uniform and harmonical, by not breaking them fufficiently to contrary motions: the reafon whereof I fuppofe to be, becaufe they themfelves were men dedicated to a private, free, and unapplied courfe of life. For as we fee, upon the lute or like inftrument, a ground, though it be fweet and have Thow of many changes, yet breaketh not the hand to fuch ftrange and hard ftops and paffages as a fet fong or voluntary; much after the fame manner was the diverfity between a philofophical and a civil life. And therefore men are to imitate the wifdom of jewellers; who, if there be a grain, or a cloud, or an ice, ${ }^{65}$ which may be ground forth without taking too much of the ftone, they help it; but if it hould leffen and abate the ftone too much, they will not meddle with it: fo ought men fo to procure ferenity as they deftroy not magnanimity.

Having therefore deduced the good of man which is private and particular, as far as feemeth (2.) Good relative. fit; we will now return to that good of man which

$$
\begin{aligned}
& 64 \text { Juv. Sat. x. } 35^{8} \text {. } \\
& 65 \text { "Nubecula aliqua aut gluciecula," De Augm. }
\end{aligned}
$$


refpecteth and beholdeth fociety, which we may term Duty; becaufe the term of Duty is more proper to a mind well framed and difpofed towards others, as the term of virtue is applied to a mind well formed and compofed in itfelf: though neither can a man underftand virtue without fome relation to fociety, nor Duty without an inward difpofition. This part may feem at firft to pertain to fcience civil and politic : but not if it be well obferved; for it concerneth the regiment and government of every man over himfelf, and not over others. And as in architecture the direction of framing the pofts, beams, and other parts of building, is not the fame with the manner of joining them and erecting the building; and in mechanicals, the direction how to frame an inftrument or engine, is not the fame with the manner of fetting it on work and employing it, (and yet neverthelefs in expreffing of the one you incidentally exprefs the aptnefs towards the other;) fo the doctrine of conjugation of men in fociety differeth from that of their conformity thereunto.

(a.) Of man

This part of Duty is fubdivided into two parts : as a citizen. the common Duty of every man, as a man or (b.) As a 10- member of a ftate; the other, the refpective or cial being. fpecial Duty of every man, in his profeflion, vocation, and place. The firft of thefe is extant and well laboured, as hath been faid. The fecond likewife I may report rather difperfed than deficient; which manner of difperfed writing in this kind of argument I acknowledge to be beft. For who can take upon him to write of the proper 
duty, virtue, challenge, and right of every feveral vocation, profeffion, and place? For although fometimes a looker on may fee more than a gamefter, and there be a proverb more arrogant than found, that the vale beft difcovereth the bill; yet there is fmall doubt but that men can write beft, and moft really and materially, in their own profeffions; and that the writing of ipeculative men of active matter, for the molt part, doth feem to men of experience, as Phormio's argument of the wars feemed to Hannibal, to be but dreams and dotage. ${ }^{66}$ Only there is one vice which accompanieth them that write in their own profeffions, that they magnify them in excels. But generally it were to be wifhed, as that which would make learning indeed folid and fruitful, that active men would or could become writers.

In which kind I cannot but mention, bonoris caufa, your Majefty's excellent book touching the duty of a king; ${ }^{67}$ a work richly compounded of divinity, morality, and policy, with great afperfion of all other arts; and being, in mine opinion, one of the moft found and healthful writings that I have read; not diftempered in the heat of invention, nor in the coldnefs of negligence; not fick of dizzinefs, ${ }^{68}$ as thofe are who leefe themfelves in their order; nor of convulfions, as thofe which cramp in matters impertinent; not favouring of perfumes and paintings, as thofe do who feek to

65 Cic. de Orat. ii. I 8.75 .

67 Sc. the Bafilicon Doron.

ờ Dizzinefs-Latin Vertigines. The ed. 1605 has dufineffe, 1629 and $16_{33}$, bufinefe. 


\section{ADVANCEMENT OF LEARNING.}

pleafe the reader more than nature beareth; and chiefly well difpored in the fpirits thereof, being agreeable to truth and apt for action; and far removed from that natural infirmity, whereunto I noted thofe that write in their own profeffions to be fubject, which is, that they exalt it above meafure: for your majefty hath truly defcribed, not a king of Aflyria or Perfia in their extern glory, but a Mofes or a David, paftors of their people. Neither can I ever leefe out of my remembrance, what I heard your majefty, in the fame facred fpirit of Government, deliver in a great caufe of judicature, which was, That kings ruled by their laws, as God did by the laws of nature; and ought as rarely to put in ufe their fupreme prerogative, as God doth bis power of working miracles. And yet notwithftanding, in your book of a free monarchy, ${ }^{69}$ you do well give men to underftand, that you know the plenitude of the power and right of a king, as well as the circle of his office and duty. Thus have I prefumed to allege this excellent writing of your majefty, as a prime or eminent example of tractates concerning fpecial and refpective duties: wherein I hould have faid as much, if it had been written a thoufand years fince: neither am I moved with certain courtly decencies, which efteem it flattery to praife in prefence; no, it is Alattery to praife in abfence; that is, when either the virtue is abfent, or the occafion is abfent; and fo the praife is not natural, but forced, either in truth or in time. But let Cicero be read in his oration

69 Sc. "The True Law of Free Monarchies." 
pro Marcello, which is nothing but an excellent table of Cæefar's virtue, and made to his face; befides the example of many other excellent perfons, wifer a great deal than fuch obfervers; and we will never doubt, upon a full occafion, to give juft praifes to prefent or abfent.

But to return: there belongeth further to the handling of this part, touching the duties of profeffions and vocations, a relative or oppofite, touchThe evils of focial life illing the frauds, cautels, impoltures, and vices of every profeffion, which hath been likewife handled: but how ? rather in a fatire and cynically, than ferioufly and wifely: for men have rather fought by wit to deride and traduce much of that which is good in profeffions, than with judgment to difcover and fever that which is corrupt. For, as Salomon faith, he that cometh to feek after knowledge with a mind to fcorn and cenfure, fhall be fure to find matter for his humour, but no matter for his inftruction: 2uarenti derifori fcientiam ip fa fe abfcondit; fed fudiofo fit obviam. ${ }^{70}$ But the managing of this argument with integrity and truth, which I note as deficient, feemeth to me to be one of the belt fortifications for honefty and virtue that can be planted. For, as the fable goeth of the bafilin, that if he fee you firt, you die for it; but if you fee him firft, he dieth : fo it is with deceits and evil arts; which, if they be firft efpied they leefe their life; but if they prevent, they endanger. So that we are much beholden to $\mathrm{Ma}$ chiavel and others, that write what men do, and 


\section{ADVANCEMENT OF LEARNING.}

not what they ought to do. For it is not poffible to join ferpentine wifdom with columbine innocency, ${ }^{71}$ except men know exactly all the conditions of the ferpent : his bafenefs and going upon his belly, his volubility and lubricity, his envy and fting, and the reft; that is, all forms and natures of evil : for without this, virtue lieth open and unfenced. Nay, an honeft man can do no good upon thofe that are wicked to reclaim them, without the help of the knowledge of evil. For men of corrupted minds prefuppofe that honefty groweth out of fimplicity of manners, and believing of preachers, fchoolmafters, and men's exterior language : fo as, except you can make them perceive that you know the utmoft reaches of their own corrupt opinions, they defpife all morality; Non recipit fultus verba prudentia, nift en dixeris qua verfantur in corde ejus. $7^{2}$

Unto this part, touching Refpective Duty, doth alfo appertain the duties between hurband and wife, parent and child, mafter and fervant : fo likewife the laws of friendfhip and gratitude, the civil bond of companies, colleges, and politic bodies, of neighbourhood, and all other proportionate duties; not as they are parts of government and fociety, but as to the framing of the mind of particular perfons.

Of cafes of cafuiftry herein.
The knowledge concerning good refpecting Society doth handle it alfo, not fimply alone, but comparatively; whereunto belongeth the weighing of duties between perfon and perfon, cafe and cafe, particular and public: as we fee in the pro-

i1 Matt. x. 16.

72 Prov. xriii. 2. From the Vulgate. 
ceeding of Lucius Brutus againft his own fons, which was fo much extolled; yet what was faid?

Infelix, utcunque ferent ea fata minores. ${ }^{73}$

So the cafe was doubtful, and had opinion on both fides. Again, we ree when M. Brutus and Caffius invited to a fupper certain whofe opinions they meant to feel, whether they were fit to be made their affociates, and caft forth the queftion touching the killing of a tyrant being a ufurper, they were divided in opinion $;^{74}$ fome holding that fervitude was the extreme of evils, and others that tyranny was better than a civil war: and a number of the like cafes there are of comparative duty; amongft which that of all others is the moft frequent, where the queftion is of a great deal of good to enfue of a fmall injuftice. Which Jafon of Theffalia determined againft the truth: Aliqua Junt injufte facienda, ut multa jufte fieri poljint. ${ }^{5}$ But the reply is good, Auctorem prafentis juftitice babes, jponforem futurce non babes. Men muft purfue things which are juft in prefent, and leave the future to the divine Providence. So then we pafs on from this general part touching the exemplar and defcription of good.

Now therefore that we have fpoken of this fruit of life, it remaineth to fpeak of the hufbandry that belongeth thereunto; without which part the former feemeth to be no better than a fair image, or

De Aug. vi1. 3 . (ii.) Of Moral Culture. Its excel. lence.

${ }^{3}$ Virg. En. vi. 823. Bacon, or a mifprint, has fubftituted faia for faEta.

${ }_{74}$ See Plutarch, Life of Brutus.

75 Plut. Prac. Gir. Reip. 24. 


\section{$252 A D V A N C E M E N T$ OF LEARNING.}

ftatua, which is beautiful to contemplate, but is without life and motion; whereunto Ariftotle himfelf fubfcribeth in thefe words: Neceffe eft filicet de virtute dicere, et quid fit, et ex quibus gignatur. Inutile enim fere fuerit virtutem quidem nofle, acquirenda autem ejus modos et vias ignorare: non enim de virtute tantum, qua $\int p e c i e$ jit, querendum eft, fed et quomodo Jui copiam faciat: utrumque enim volumus, et rem ipfam noffe, et ejus compotes fieri: boc autem ex voto non fuccedet, nifi fciamus et ex quibus et quomodo.i6 In fuch full words and with fuch iteration doth he inculcate this part. So faith Cicero in great commendation of Cato the fecond, that he had applied himfelf to philofophy, Non ita difputandi caufa, fed ita vivendi.it And although the neglect of our times, wherein few men do hold any confultations touching the reformation of their life, (as Seneca excellently faith) De partibus vitce quifque deliberat, de fummâ nemo, i8 may make this part feem fuperfluous; yet I muft conclude with that aphorifm of Hippocrates, Qui gravi morbo correpti dolores non fentiunt, iis mens egrotat, ${ }^{i 9}$ they need medicine, not only to affuage the difeafe, but to awake the fenfe. And if it be faid, that the cure of men's minds belongeth to facred divinity, it is moft true: but yet moral philofophy may be preferred unto her as a wife fervant and humble handmaid. For as the Pfalm faith, that the eyes of the bandmaid look perpetually towards the mif-

${ }_{76}$ Eth. Mag. A. i. 3.

77 Cic. pro Mur. xxx. (62.)

78 Sen. ad Lucil. Epift. 71 . where it is "de partibus vitæ omnes deliberamus, de tota nemo." ${ }^{9}$ Hippoc. Apb. ii. 6. 


\section{BOOK II.}

$\operatorname{tre} \int s^{80}$ and yet no doubt many things are left to the difcretion of the handmaid, to difcern of the miftrefs' will; fo ought moral philofophy to give a conftant attention to the doctrines of divinity, and yet fo as it may yield of herfelf, within due limits, many found and profitable directions.

This part therefore, becaufe of the excellency thereof, I cannot but find exceeding ftrange that it is not reduced to written inquiry: the rather, becaufe it confifteth of much matter, wherein both fpeech and action is often converfant; and fuch wherein the common talk of men, (which is rare, but yet cometh fometimes to pafs,) is wifer than their books. It is reafonable therefore that we propound it in the more particularity, both for the worthinefs, and becaufe we may acquit ourfelves for reporting it deficient; which feemeth almoft incredible, and is otherwife conceived and prefuppofed by thofe themfelves that have written. We will therefore enumerate fome heads or points Some heads thereof. thereof, that it may appear the better what it is, and whether it be extant.

Firft, therefore, in this, as in all things which are practical, we ought to caft up our account, what is in our power, and what not; for the one may be dealt with by way of alteration, but the other by way of application only. The hurbandman cannot command neither the nature of the earth nor the feafons of the weather; no more can the phyfician the conftitution of the patient, nor the variety of accidents. So in the culture

(1.) What is in our power?

As yet but little handled in books. therefor 


\section{$254 A D V A N C E M E N T$ OF LEARNING.}

and cure of the mind of man, two things are without our command; points of nature, and points of fortune. For to the bafis of the one, and the conditions of the other, our work is limited and tied. In thefe things therefore it is left unto us to proceed by application;

Vincenda eft omnis fortuna ferendo: ${ }^{81}$

and fo likewife,

Vincenda eft omnis Natura ferendo.

But when that we fpeak of fuffering, we do not fpeak of a dull and neglected fuffering, but of a wife and induftrious fuffering, which draweth and contriveth ufe and advantage out of that which feemeth adverfe and contrary; which is that property which we call accommodating or applying. Now the wifdom of application refteth principally in the exact and diftinct knowledge of the precedent ftate or difpofition, unto which we do apply: for we cannot fit a garment, except we firft take meafure of the body.

(2) Men's So then the firlt article of this knowledge is to ditierent characters muft be ftudied. fet down found and true diftributions and defcriptions of the feveral characters and tempers of men's natures and difpofitions; efpecially having regard to thofe differences which are moft radical in being the fountains and caufes of the reft, or molt frequent in concurrence or commixture; wherein it is not the handling of a few of them in paffage, the better to defcribe the mediocrities of virtues, that can fatisfy this intention. For if it deferve

81 Virg. $2 E n$. v. 7 10. "Superanda omnis fortuna ferendo eft." 
to be confidered, that there are minds which are proportioned to great matters, and others to fmall,,$^{82}$ (which Ariftotle handleth, or ought to have handled, by the name of magnanimity;) doth it not deferve as well to be confidered, that there are minds proportioned to intend many matters, and others to few? So that fome can divide themfelves: others can perchance do exactly well, but it muft be but in few things at once: and fo there cometh to be a narrownefs of mind, as well as a pufillanimity. And again, that fome minds are proportioned to that which may be difpatched at once, or within a Phort return of time; others to that which begins afar off, and is to be won with length of purfuit :

\section{Jam tum tenditque fovetque. ${ }^{83}$}

So that there may be fitly faid to be a longanimity, which is commonly alfo afcribed to God as a magnanimity. So further deferved it to be confidered by Ariftotle; that there is a difpofition in converfation, (Juppofing it in things wubich do in no fort touch or concern a man's felf, to foothe and pleafe; and a difpofition contrary to contradict and cross: and deferveth it not much better to be confidered, that there is a difpofition, not in converfation or talk, but in matter of more ferious nature, (and fuppofing it fill in things merely indifferent,) to take pleafure in the good of another: and a dijpofition contrariwife, to take diftafte at the good of another ?8t which

${ }^{82}$ Arift. Etb. Nic, iv. 7.

${ }^{83}$ Virg. En. i. 22.

${ }_{84}$ Etb. Nic, iv. 6. 


\section{ADVANCEMENT OF LEARNING.}

is that property ${ }^{85}$ which we call good nature or ill nature, benignity or malignity: and therefore I cannot fufficiently marvel that this part of knowledge, touching the feveral characters of natures and difpofitions, fhould be omitted both in morality and policy ; confidering it is of fo great miniftry and fuppeditation to them both. A man fhall find in the traditions of aftrology fome pretty and apt divifions of men's natures, according to the predominances of the planets; lovers of quiet, lovers of action, lovers of victory, lovers of honour, lovers of pleafure, lovers of arts, lovers of change, and fo forth. A man thall find in the wifeft fort of thefe relations which the Italians make touching conclaves, the natures of the feveral cardinals handfomely and lively painted forth : a man thall meet with in every day's conference, the denominations of jenfitive, dry, formal, real, bumorous, certain, buomo di prima impreffone, buomo di ultima impreffione, and the like: and yet neverthelefs this kind of obfervation wandereth in words, but is not fixed in inquiry. For the diftinctions are found, many of them, but we conclude no precepts upon them: wherein our fault is the greater; becaufe both hiftory, poefy, and daily experience are as goodly fields where thefe obfervations grow ; whereof we make a few pofies to hold in our hands, but no man bringeth them to the confectionary, that receipts might be made of them for ufe of life.

with their Of much like kind are thofe impreffions of nafex, age, 65 In all three early ed. this word is printed properly. 
fex, by the age, by the region, by health and ficknefs, by beauty and deformity, and the like, which are inherent and not extern; and again, thofe which are caufed by extern fortune; as fovereignty, nobility, obfcure birth, riches, want, magiftracy, privatenefs, profperity, adverfity, conftant fortune, variable fortune, rifing per faltum, per gradus, and the like. And therefore we fee that Plautus maketh it a wonder to fee an old man beneficent, benignitas bujus ut adolefcentuli eft. ${ }^{86} \mathrm{St}$. $\mathrm{Paul}$ concludeth that feverity of difcipline was to be ufed to the Cretans, increpa cos dure, upon the difpofition of their country, Cretenfes femper mendaces, male beftice, ventres pigri. ${ }^{87}$ Sallult noteth that it is ufual with kings to defire contradictories: Sed plerumque regia voluntates, ut vebementes funt, fic mobiles, fapeque ipfae fibi adverfa. ${ }^{88}$ Tacitus obferveth how rarely raifing of the fortune mendeth the difpofition: folus Vejpafianus mutatus in melius. 89 Pindarus maketh an obfervation, that great and fudden fortune for the moft part defeateth men qui magnam felicitatem concoquere non poffunt. ${ }^{90}$ So the pralm howeth it is more eafy to keep a meafure in the enjoying of fortune, than in the increafe of fortune: divitic $f$ affuant, nolite cor apponere. ${ }^{91}$ Thefe obfervations, and the like, I deny not but are touched a little by Ariftotle, as in paftage in his Rhetorics, 92 and are handled in fome fcattered difcourfes: but they were never

86 Plaut. Mil. Glor. iii. I. 39.

89 Bell. Jug. I Ij.

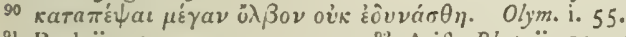

91 Ps. Ixii. 10.
87 Tit. i. 12.

89 Tac. Hift. i. 50.
9: Arift. Rbet. ii. I 2-17. 


\section{ADVANCEMENT OF LEARNING.}

incorporated into moral philofophy, to which they do effentially appertain; as the knowledge of the diverfity of grounds and moulds doth to agriculture, and the knowledge of the diverfity of complexions and conftitutions doth to the phyfician; except we mean to follow the indifcretion of empirics, which minifter the fame medicines to all patients.

Alfo their

Another article of this knowledge is the inquiry affections. touching the affections; for as in medicining of the body, it is in order firft to know the divers complexions and conftitutions; fecondly, the difeafes; and laftly, the cures: fo in medicining of the mind, after knowledge of the divers characters of men's natures, it followeth, in order, to know the difeafes and infirmities of the mind, which are no other than the perturbations and diftempers of the affections. For as the ancient politiques in popular ftates ${ }^{93}$ were wont to compare the people to the fea, and the orators to the winds; becaufe as the fea would of itfelf be calm and quiet, if the winds did not move and trouble it; fo the people would be peaceable and tractable, if the feditious orators did not fet them in working and agitation: fo it may be fitly faid, that the mind in the nature thereof would be temperate and ftayed, if the affections, as winds, did not put it into tumult and perturbation. And here again I find frange, as before, that Ariftotle thould have written divers volumes of ethics, and never handled the affec-

93 Bacon here feems to refer to Solon's lines on Pififtratus. Ellis' ed. quotes Cic. pro Cluent. 49. 
tions, which is the principal fubject thereof; and yet in his Rhetorics, where they are confidered but collaterally, and in a fecond degree, as they may be moved by fpeech, he findeth place for them, ${ }^{9+}$ and handleth them well for the quantity; but where their true place is, he pretermitteth them. For it is not his difputations about pleafure and pain that can fatisfy this inquiry, no more than he that fhould generally handle the nature of light can be faid to handle the nature of colours; for pleafure and pain are to the particular affections as light is to particular colours. Better travails, I fuppofe, had the Stoics taken in this argument, as far as I can gather by that which we have at fecond hand. But yet, it is like, it was after their manner, rather in fubtilty of definitions, (which in a fubject of this nature are but curiofities, ) than in active and ample defcriptions and obfervations. So likewife I find fome particular writings of an elegant nature, touching fome of the affections; as of anger, of comfort upon adverfe accidents, of tendernefs of countenance, and other. ${ }^{95}$

But the poets and writers of hiftories are the beft doctors of this knowledge; where we may find painted forth with great life, how affections are kindled and incited; and how pacified and refrained; and how again contained from act and further degree; how they difclofe themfelves; how they work; how they vary; how they gather and fortify; how they are inwrapped one within another; and how they do fight and encounter

Beft treated by Poets and Hiftorians.

94 Arift. Rhet. ii. I-I I. 95 Such as Plutarch's and Seneca's. 


\section{ADVANCEMENT OF LEARNING.}

one with another; and other the like particularities: amongft the which this laft is of fpecial ufe in moral and civil matters; how, I fay, to fet affection againft affection, and to mafter one by another; even as we ufe to hunt beaft with beaft, and fly bird with bird, which otherwife percafe we could not fo eafily recover: upon which foundation is erected that excellent ufe of premium and poena, whereby civil ftates confift: employing the predominant affections of fear and hope, for the fupprefling and bridling the reft. For as in the government of fates it is fometimes neceffary to bridle one faction with another, fo it is in the government within.

Points within our own command.

Now come we to thofe points which are within our own command, and have force and operation upon the mind, to affect the will and appetite, and to alter manners: wherein they ought to have handled cuftom, exercife, habit, education, example, imitation, emulation, company, friends, praife, reproof, exhortation, fame, laws, books, ftudies: thefe as they have determinate ufe in moralities, from thefe the mind fuffereth; and of thefe are fuch receipts and regiments compounded and defcribed, as may feem to recover or preferve the health and good eftate of the mind, as far as pertaineth to human medicine: of which number we will infift upon fome one or two, as an example of the reft, becaufe it were too long to profecute all; and therefore we do refume cuftom and habit to fpeak of.

Cuftom and The opinion of Ariftotle feemeth to me a negliabit. 
ligent opinion, that of thofe things which confift by nature nothing can be changed by cuftom; ufing for example, that if a ftone be thrown ten thoufand times up, it will not learn to afcend $; 96$ and that by often feeing or hearing, we do not learn to fee or hear the better. For though this principle be true in things wherein nature is peremptory (the reafon whereof we cannot now ftand to difcufs), yet it is otherwife in things wherein nature admitteth a latitude. For he might fee that a ftrait glove will come more eafily on with ufe; and that a wand will by ufe bend otherwife than it grew; and that by ufe of the voice we fpeak louder and ftronger; and that by ufe of enduring heat or cold, we endure it the better, and the like: which latter fort have a nearer refemblance unto that fubject of manners he handleth, than thofe inftances which he allegeth. But allowing his conclufion, that virtues and vices confift in habit, he ought fo much the more to have taught the manner of fuperinducing that habit: for there be many precepts of the wife ordering the exercifes of the mind, as there is of ordering the exercifes of the body; whereof we will recite a few.

The firft fhall be, that we beware we take not some preat the firft either too high a ftrain, or too weak: for if too high, in a diffident nature you difcourage, cepts thereunto. in a confident nature you breed an opinion of facility, and fo a floth; and in all natures you breed a farther expectation than can hold out, and fo an 
infatisfaction in the end: if too weak on the other fide, you may not look to perform and overcome any great tafk.

Another precept is, to practife all things chiefly at two feveral times, the one when the mind is beft difpofed, the other when it is worft difpofed; that by the one you may gain a great ftep, by the other you may work out the knots and ftonds of the mind, and make the middle times the more eafy 97 and pleafant.

Another precept is, that which Ariftotle mentioneth by the way, which is to bear ever towards the contrary extreme of that whereunto we are by nature inclined; like unto the rowing againft the ftream, or making a wand ftraight by bending ${ }^{98}$ him contrary to his natural crookednefs. 99

Another precept is, that the mind is brought to any thing better, and with more fweetnefs and happinefs, if that whereunto you pretend be not firft in the intention, but tanquam aliud agendo, becaufe of the natural hatred of the mind againft neceffity and conftraint. Many other axioms there are touching the managing of exercife and cuftom; which being fo conducted doth prove indeed another nature; but being governed by chance doth commonly prove but an ape of nature, and bringing forth that which is lame and counterfeit.

So if we thould handle books and ftudies, and what influence and operation they have upon man-

97 Ed. 1605, has eafily - Latin, "facile et placide delabentur"from which Mr. Spedding fuggefts that Bacon may have originally written "run more eafily."

${ }_{98}$ Ed. 1605 and 1624 have binding. 99 Etb. Nic. ii. 9. 5. 
ners, are there not divers precepts of great caution and direction appertaining thereunto? Did not one of the fathers ${ }^{1}$ in great indignation call poefy, vinum demonum, becaufe it increafeth temptations, perturbations, and vain opinions? Is not the opinion of Ariftotle worthy to be regarded, wherein he faith, That young men are no fit auditors of moral philofophy, becaufe they are not fettled from the boiling beat of their affections, nor attempered with time and experience?? And doth it not hereof come, that thofe excellent books and difcourfes of the ancient writers, (whereby they have perfuaded unto virtue moft effectually, by reprefenting her in ftate and majefty, and popular opinions againft virtue in their parafites' coats fit to be fcorned and derided, ) are of fo little effect towards honefty of life, becaufe they are not read and revolved by men in their mature and fettled years, but confined almoft to boys and beginners? But is it not true alfo, that much lefs young men are fit auditors of matters of policy, till they have been thoroughly feafoned in religion and morality; left their judgments be corrupted, and made apt to think that there are no true differences of things, but according to utility and fortune, as the verfe defcribes it,

Profperum et felix fcelus virtus vocatur $;^{3}$

and again,

Ille crucem pretium fceleris tulit, hic diadema : ${ }^{4}$

which the poets do fpeak fatirically, and in indignation on virtue's behalf; but books of policy do

1 Probably St. Auguftine.

3 Senec. Herc. Fur. 25 I.

2 Etb. Nic. i. 3. 5.

4 Juv. Sat. xiii. 105. 


\section{ADVANCEMENT OF LEARNING.}

fpeak it feriounly and pofitively; for fo it pleafeth Machiavel to fay, That if Cafar bad been overthrown, be would have been more odious than ever was Catiline; ${ }^{5}$ as if there had been no difference but in fortune, between a very fury of luft and blood, and the moft excellent fpirit (his ambition referved) of the world? Again, is there not a caution likewife to be given of the doctrines of moralities themfelves, (fome kinds of them,) left they make men too precife, arrogant, incompatible; as Cicero faith of Cato, In Marco Catone bec bona qua videmus divina et egregia, ipfus fcitote effe propria; que nonnunquam requirimus, ea funt omnia non a naturâ, fed a magiftro?6 Many other axioms and advices there are touching thofe proprieties and effects which ftudies do infufe and inftil into manners. And fo likewife is there touching the ufe of all thofe other points, of company, fame, laws, and the reft, which we recited in the beginning in the doctrine of morality.

But there is a kind of culture of the mind that feemeth yet more accurate and elaborate than the reft, and is built upon this ground; that the minds of all men are at fome times in a ftate more perfect, and at other times in a ftate more depraved. The purpofe therefore of this practice is to fix and cherifh the good hours of the mind, and to obliterate and take forth the evil. The fixing of the good hath been practifed by two means, vows or conftant refolutions, and obfervances or exer- 


\section{BOOK II.}

cifes; which are not to be regarded fo much in themfelves, as becaufe they keep the mind in continual obedience. The obliteration of the evil hath been practifed by two means, fome kind of redemption or expiation of that which is paft, and an inception or account de novo, for the time to come. But this part feemeth facred and religious, and juftly; for all good moral philofophy, as was faid, is but a handmaid to religion.

Wherefore we will conclude with that laft point, which is of all other means the moft compendious and fummary, and again, the mort noble and effectual to the reducing of the mind unto virtue and good eftate; which is the electing and proConcluding with advice as to the ends of Life to be chofen. pounding unto a man's felf good and virtuous ends of his life, fuch as may be in a reafonable fort within his compals to attain. For if thefe two things be fuppofed, that a man fet before him honeft and good ends, and again, that he be refolute, conftant, and true unto them; it will follow that he fhall mould himfelf into all virtue at once. And this indeed is like the work of nature; whereas the other courfe is like the work of the hand. For as when a carver makes an image, he hapes only that part whereupon he worketh, (as if he be upon the face, that part which fhall be the body is but a rude ftone ftill, till fuch time as he comes to it;) but, contrariwife, when nature makes a flower or living creature, the formeth rudiments of all the parts at one time : fo in obtaining virtue by habit, while a man practifeth temperance, he doth not profit much to fortitude, nor the like: but when 
he dedicateth and applieth himfelf to good ends, look, what virtue foever the purfuit and paffage towards thofe ends doth commend unto him, he is invefted of a precedent difpofition to conform himfelf thereunto. Which ftate of mind Ariftotle doth excellently exprefs himfelf that it ought not to be called virtuous, but divine: his words are thefe: Immanitati autem confentaneum eft opponere eam, qua fupra bumanitatem eft, beroicam five divinam virtutem: and a little after, Nam ut fera neque vitium neque virtus eft, fic neque $D e i$ : Sed bic quidem fatus altius quiddam virtute eft, ille aliud quiddam a vitio.7 And therefore we may fee what celfitude of honour Plinius Secundus attributeth to Trajan in his funeral oration $;^{8}$ where he faid, That men needed to make no other prayers to the gods, but that they would continue as good Lords to them as Trajan bad been; 9 as if he had not been only an imitation of divine nature, but a pattern of it. But thefe be heathen and profane paffages, having but a fhadow of that divine ftate of mind, which religion and the holy faith doth conduct men unto, by imprinting upon their fouls charity, which is excellently called the bond of perfection, becaufe it comprehendeth and fafteneth all virtues together. ${ }^{10}$ And as it is elegantly faid by Menander of vain love, which is but a falfe imitation of divine

7 Arif. Etb. Nic. vii. I, I.

8 Bacon feems to have thought that the Panegyric was delivered after Trajan's death. He became aware of his error before the Latin was publinhed; for he there omits the words "in his funeral oration."

${ }^{8}$ Plin. Paneg. 74.

10 Colofs, iii. I4. 
love, Amor melior Sopbifta lavo ad bumanamvitam, ${ }^{11}$ that love teacheth a man to carry himfelf better than the fophift or preceptor; which he calleth left-handed, becaufe, with all his rules and precepts, he cannot form a man fo dexteroufly, nor with that facility to prize himfelf and govern himfelf, as love can do : fo certainly, if a man's mind be truly inflamed with charity, it doth work him fuddenly into a greater perfection than all the doctrine of morality can do, which is but a fophift in comparifon of the other. Nay further, as Xenophon obferved truly, that all other affections, though they raife the mind, yet they do it by diftorting and uncomelinefs of ecftafies or excefles; but only love doth exalt the mind, and neverthelefs at the fame inftant doth fettle and compofe it $^{12}$ fo in all other excellencies, though they advance nature, yet they are fubject to excers; only charity admitteth no excefs. For fo we fee, afpiring to be like God in power, the angels tranfgreffed and fell ; Afcendam, et ero fimilis altiffmo: ${ }^{13}$ by afpiring to be like God in knowledge, man tranfgreffed and fell; Eritis ficut Dii, fcientes bonum et malum $:^{14}$ but by afpiring to a fimilitude of God in goodnefs or love, neither man nor angel ever tranfgreffed, or thall tranfgrefs. For unto that imitation we are called: Diligite inimicos veftros, benefacite eis qui oderunt vos, et orate pro

" "Not Menander but Anaxandrides-

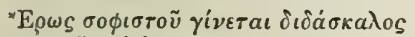

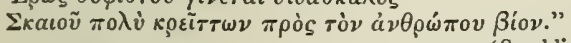

12 Xen. Symp. ad init.

13 Ifai. xiv. I4.

(Spedding.)

14 Gen. iii. 5 . 
268 ADVANCEMENT OF LEARNING.

perfequentibus et calumniantibus vos, ut fitis filii Patris veftri qui in coelis eft, qui folem fuum oriri facit fuper bonos et malos, et pluit fuper juftos et injuftos. ${ }^{15}$ So in the firft platform of the divine nature itfelf, the heathen religion fpeaketh thus, $O p$ timus Maximus: and the facred Scriptures thus, Mifericordia ejus fuper omnia opera ejus. ${ }^{16}$

Conclufion. Wherefore I do conclude this part of moral knowledge, concerning the culture and regimen of the mind; wherein if any man, confidering the parts thereof which I have enumerated, do judge that my labour is but to collect into an art of fcience that which hath been pretermitted by others, as matter of common fenfe and experience, he judgeth well. But as Philocrates fported with Demofthenes, rou may not marvel, Athenians, that Demofthenes and I do differ; for be drinketh water, and $I$ drink wine $;^{17}$ and like as we read of an ancient parable of the two gates of fleep,

Sunt geminæ fomni portæ: quarum altera fertur Cornea, qua veris facilis datur exitus umbris : Altera candenti perfecta nitens elephanto, Sed falfa ad colum mittunt infomnia manes: ${ }^{18}$

fo if we put on fobriety and attention, we fhall find it a fure maxim in knowledge, that the more pleafant liquor of wine is the more vaporous, and the braver gate of ivory fendeth forth the falfer dreams.

But we have now concluded that general part of human philofophy, which contemplateth man

15 Luke vi. $27,28$.

17 Demofth. de Fals. Leg. p. 355.
16 Ps. cxlv, 9.

18 Virg. En. vi. 894. 
fegregate, and as he confifteth of body and fpirit. Wherein we may further note, that there feemeth to be a relation or conformity between the good of the mind and the good of the body. For as we divided the good of the body into health, beauty, ftrength, and pleafure; fo the good of the mind, inquired in rational and moral knowledges, tendeth to this, to make the mind found, and without perturbation; beautiful, and graced with decency; and ftrong and agile for all duties of life. Thefe three, as in the body, fo in the mind, feldom meet, and commonly fever. For it is eafy to obferve, that many have ftrength of wit and courage, but have neither health from perturbations, nor any beauty or decency in their doings; fome again have an elegancy and finenefs of carriage, which have neither foundnefs of honefty, nor fubftance of fufficiency: and fome again have honeft and reformed minds, that can neither become themfelves nor manage bufinefs: and fometimes two of them meet, and rarely all three. As for pleafure, we have likewife determined that the mind ought not to be reduced to ftupid, 19 but to retain pleafure ; confined rather in the fubject of it, than in the ftrength and vigour of it.

19 Should this be fupidity or fupor? In the Latin it is " red lat animum-non ftupidum, led voluptatis-fenfum vivide retinentem." 
De Aug. viIt. I.

(ii.) Philofophy congregate (or of focieties.)

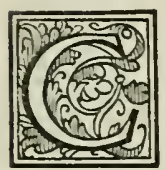

IVIL knowledge is converfant about a fubject which of all others is moft immerfed in matter, and hardlieft reduced to axiom. Neverthelefs, as Cato the Cenfor faid, That the Romans were like Beep, for that a man might better drive a flock of them, than one of them; for in a flock, if you could but get fome few to go right, the reft would follow: ${ }^{20}$ fo in that refpect moral philofophy is more difficile than policy. Again, moral philofophy propoundeth to itfelf the framing of internal goodnefs; but civil knowledge requireth only an external goodnefs; for that as to fociety fufficeth. And therefore it cometh oft to pafs that there be evil times in good governments: for fo we find in the holy ftory, when the kings were good, yet it is added, Sed adbuc populus non direxerat cor fuum ad Dominum Deum patrum fuorum. ${ }^{21}$ Again, ftates, as great engines, move flowly, and are not fo foon put out of frame: for as in Egypt the feven good years fuftained the feven bad, fo governments for a time well grounded, do bear out errors following; but the refolution of particular perfons is more fuddenly fubverted. Thefe refpects do fomewhat qualify the extreme difficulty of civil knowledge.

Is of three This knowledge hath three parts, according to parts.

(a.) In $\mathrm{Con}$ verfation. (b. ) In Neguciation. the three fummary actions of fociety; which are converfation, negotiation, and government. For man feeketh in fociety comfort, ufe, and protec-
212 Chron. $x x .33$. 
tion : and they be three wifdoms of divers natures, which do often fever: wifdom of the behaviour, (c.) In Government. wifdom of bufinefs, and wifdom of ftate.

The wifdom of converfation ought not to be over much affected, but much lefs defpifed; for it (a.) In Conhath not only an honour in itfelf, but an influence alfo into bufinefs and government. The poet faith,

\section{Nec vultu deftrue verbo tuo $:^{22}$}

a man may deftroy the force of his words with his countenance: fo may he of his deeds, faith Cicero, recommending to his brother affability and eafy accefs; Nil intereft babere oftium apertum, vultum claufum; $;^{23}$ it is nothing won to admit men with an open door, and to receive them with a fhut and referved countenance. So, we fee, Atticus, before the firft interview between Cæa ar and Cicero, the war depending, did ferioufly advife Cicero touching the compofing and ordering of his countenance and gefture. ${ }^{24}$ And if the government of the countenance be of fuch effect, much more is that of the fpeech, and other carriage appertaining to converfation; the true model whereof feemeth to me well expreffed by Livy, though not meant for this purpofe: Ne aut arrogans videar, aut obnoxius; quorum alterum eft alience libertatis obliti, alterum $\int u a: 25$ The fum of behaviour is to retain a man's own dignity, without intruding upon the liberty of others. On the

${ }_{22}$ Ovid, ii. 312, de Art. Am.

23 Q. Cic. de Petit. Conful. xi. 44.

24 Cic. ad Att. ix. 12. 25 Livy, xxiii. 12. 
other fide, if behaviour and outward carriage be intended too much, firft it may pars into affectation, and then Quid deformius quam fcenam in vitam transferre (to act a man's life)? But although it proceed not to that extreme, yet it confumeth time, and employeth the mind too much. And therefore as we ufe to advife young ftudents from company keeping, by faying, Amici fures temporis : fo certainly the intending of the difcretion of behaviour is a great thief of meditation. Again, fuch as are accomplifhed in that hour ${ }^{26}$ of urbanity pleafe themfelves in it, ${ }^{27}$ and feldom afpire to higher virtue; whereas thofe that have defect in it do feek comelinefs by reputation; for where reputation is, almoft everything becometh; but where that is not, it muft be fupplied by puntos, and compliments. Again, there is no greaier impediment of action than an over-curious obfervance of decency, and the guide of decency, which is time and feafon. For as Salomon faith, 2ui refpicit ad ventos, non feminat; et qui refpicit ad nubes, non metet::28 a man muft make his opportunity, as oft as find it. To conclude, behaviour feemeth to me as a garment of the mind, and to have the conditions of a garment. For it ought

26 Howr, ed. 1605 ; bour, 1633 ; forme, 1629. Mr. Spedding fuggefts and prints bonor-not improbably. The Latin is, "Qui plimas in urbanitate obtinent, et ad hanc rem quafi nati videntur" - to which "primas" bonor well agrees. It might poffibly be either forw or flower. But bonor feems better, fave that the phrafe " honor of urbanity" is forced.

27 In it. Ed. 1605 and $\mathrm{I}_{33}$ have in name; 1629 , in it. Latin, "ut fibi ipfis in illa fola complaceant," which agrees with our reading.

28 Eccles. xi. 4. 


\section{BOOK II.}

to be made in fafhion; it ought not to be too curious; it ought to be thaped fo as to fet forth any good making of the mind, and hide any deformity; and above all, it ought not to be too ftrait, or reftrained for exercife or motion. But this part of civil knowledge hath been elegantly handled, and therefore I cannot report it for deficient.

The wifdom touching negotiation or bufinefs hath not been hitherto collected into writing, to the great derogation of learning, and the profeffors of learning. For from this root fpringeth chiefly De Aug. viII. 2 . (b.) In $\mathrm{Ne}-$ gociation (deficient.) that note or opinion, which by us is expreffed in adage to this effect, that there is no great concurrence between learning and wifdom. For of the three wifdoms which we have fet down to pertain to civil life, for wifdom of behaviour, it is by learned men for the moft part defpifed, as an inferior to virtue, and an enemy to meditation; for wifdom of government, they acquit themfelves well, when they are called to it, but that happeneth to few; but for the wifdom of bufinefs, wherein man's life is moft converfant, there be no books of it, except fome few fcattered advertifements, that have no proportion to the magnitude of this fubject. For if books were written of this, as the other, I doubt not but learned men with mean experience, would far excel men of long experience without learning, and outhoot them in their own bow.

Neither needeth it at all to be doubted, that this knowledge thould be fo variable as it falleth not under precept; for it is much lefs infinite than

It can be brought under precept, and is worthy. 


\section{ADVANCEMENT OF LEARNING.}

fcience of government, which, we fee, is laboured and in fome part reduced. Of this wifdom, it feemeth fome of the ancient Romans in the faddeft and wifert times were profeffors; for Cicero reporteth ${ }^{9} 9$ that it was then in ufe for fenators that had name and opinion for general wife men, as Coruncanius, Curius, Lælius, and many others, to walk at certain hours in the Place, and to give audience to thofe that would ufe their advice; and that the particular citizens would refort unto them, and confult with them of the marriage of a daughter, or of the employing of a fon, or of a purchafe or bargain, or of an accufation, and every other occafion incident to man's life. So as there is a wifdom of counfel and advice even in private caufes, arifing out of a univerfal infight into the affairs of the world; which is ufed indeed upon particular caufes propounded, but is gathered by general obfervation of $\mathrm{cafes}^{30}$ of like nature. For fo we fee in the book which $\mathrm{Q}$. Cicero writeth to his brother, De petitione confulatus, (being the only book of bufinefs that I know written by the ancients,) although it concerned a particular action fet on foot, yet the fubftance thereof confifteth of many wife and politic axioms, which contain not a temporary, but a perpetual direction in the cafe of popular elections. But chiefly we may fee in thofe aphorifms which have place among divine writings, compofed by Salomon the king, (of whom the Scriptures teftify that his heart was as the fands

${ }^{29}$ Cic. de Orat. iii. I 33, I 34 (cap. 33.)

$30 \mathrm{Ed} .1629$ and 1633 have caufes. 
of the fea, ${ }^{31}$ encompaffing the world and all worldly matters,) we fee, I fay, not a few profound and excellent cautions, precepts, pofitions, extending to much variety of occafions; whereupon we will ftay awhile, offering to confideration fome number of examples.

Sed et cunctis fermonibus qui dicuntur ne accommodes aurem tuam, ne forte audias fervum tuum maledicentem tibi. ${ }^{32}$ Here is concluded the provident ftay of inquiry of that which we would be loth to find: as it was judged great wifdom in Pompeius Magnus that he burned Sertorius' papers unperufed. ${ }^{33}$

Vir fapiens, fi cum fulto contenderit, five irafcatur, five rideat, non inveniet requiem. ${ }^{34}$ Here is defcribed the great difadvantage which a wife man hath in undertaking a lighter perfon than himfelf; which is fuch an engagement as, whether a man turn the matter to jeft, or turn it to heat, or howfoever he change copy, he can no ways quit himfelf well of it.

Qui delicatè a pueritia nutrit fervum fuum, poftea fentiet eum contumacem. ${ }^{35}$ Here is fignified, that if a man begin too high a pitch in his favours, it doth commonly end in unkindnefs and unthanktulnefs.

Vidifti virum velocem in opere fuo? coram regibus flabit, nec erit inter ignobiles. ${ }^{36}$ Here is obferved, that of all virtues for rifing to honour, quicknefs of defpatch is the beft; for fuperiors

31 I Kings iv. 29.

33 Plut, Vit. Pomp. c. 20.

35 Prov. xxix. 2I.

32 Eccles. vii. 21.

34 Prov. xxix. 9.

36 xxii. 29.

Examples of it from Solomon. 


\section{ADVANCEMENT OF LEARNING.}

many times love not to have thofe they employ too deep or too fufficient, but ready and diligent.

$V i d i$ cunctos viventes qui ambulant fub fole, cum adolefcente fecundo qui confurgit pro e0. ${ }^{37}$ Here is expreffed that which was noted by Sylla firft, and after him by Tiberius; Plures adorant folem orientem quam occidentem vel meridianum. ${ }^{38}$

Si jpiritus poteftatem babentis afcenderit fuper te, locum tuum ne demiferis; quia curatio faciet ceffare peccata maxima. ${ }^{39}$ Here caution is given, that upon difpleafure, retiring is of all courfes the unfitteft; for a man leaveth things at worft, and depriveth himfelf of means to make them better.

Erat civitas parva, et pauci in ea viri: verit contra eam rex magnus, et vadavit eam, inftruxitque munitiones per gyrum, et perfecta eft obfidio; inventufque eft in ea vir pauper et fapiens, ei liberavit eam per fapientiam fuam; et nullus deinceps recordatus eft bominis illius pauperis. ${ }^{40}$ Here the corruption of ftates is fet forth, that efteem not virtue or merit longer than they have ufe of it.

Mollis refponj 10 frangit iram. ${ }^{41}$ Here is noted that filence or rough anfwer exafperateth; but an anfwer prefent and temperate pacifieth.

Iter pigrorum quafi Sepes spinarum. ${ }^{42}$ Here is lively reprefented how laborious floth proveth in the end; for when things are deferred till the laft inftant, and nothing prepared beforehand, every

37 Eccles, iv, 15.

38 Plut. Vit. Pomp. and Tacit. Ann. vi. 46. The words vel meridianum are omitted in the Latin, as they fhould be here.

39 Eccles. $x .4$. 40 ix, 14, I5. 11 Prov. Xv. I. ${ }^{42}$ Xv. 19. 
Atep findeth a brier or an impediment, which catcheth or ftoppeth.

Melior eff finis orationis quam principium. ${ }^{43}$ Here is taxed the vanity of formal fpeakers, that ftudy more about prefaces and inducements, than upon the conclufions and iffues of fpeech.

2ui cognofcit in judicio faciem, non bene facit; ifte et pro bucella panis deferet veritatem. ${ }^{44}$ Here is noted, that a judge were better be a briber than a refpecter of perfons; for a corrupt judge offendeth not fo lightly ${ }^{45}$ as a facile.

Vir pauper calumnians pauperes fimilis eft imbri vebementi, in quo paratur fames: ${ }^{46}$ Here is expreffed the extremity of neceffitous extortions, figured in the ancient fable of the full and the hungry horfeleech.

Fons turbatus pede, et vena corrupta, eft jufus cadens coram impio. ${ }^{47}$ Here is noted, that one judicial and exemplar iniquity in the face of the world, doth trouble the fountains of juftice more than many particular injuries paffed over by connivance.

Qui fubtrabit aliquid a patre et a matre, et dicit boc non efe peccatum, particeps eft bomicidii. ${ }^{48}$ Here is noted, that whereas men in wronging their beft friends ufe to extenuate their fault, as if they might prefume or be bold upon them, it doth contrariwife indeed aggravate their fault, and turneth it from injury to impiety.

43 Eccles, vii. 8.

44 Prov. xxriii. 21.

$45 \mathrm{Ed}$. 1629 and 1633 read highly, which is clearly inferior to ligbtly, which is the reading of 1605 .
46 Prov. xxviii. 3 .
$47 \mathrm{xxv} .26$.
45 xxviii. 24. 
278 ADVANCEMENT OF LEARNING.

Noli effe amicus bomini iracundo, nec ambulato cum bomine furiofo. ${ }^{49}$ Here caution is given, that in the election of our friends we do principally avoid thofe which are impatient, as thofe that will efpoufe us to many factions and quarrels.

Qui conturbat domum fuam, pofjedebit ventum. ${ }^{50}$ Here is noted, that in domeftical feparations and breaches men do promife to themfelves quieting of their mind and contentment ; but ftill they are deceived of their expectation, and it turneth to wind.

Filius fapiens latificat patrem: filius vero fultus moefitia eft matri fuce. ${ }^{51}$ Here is diftinguifhed, that fathers have moft comfort of the good proof of their fons; but mothers have moft difcomfort of their ill proof, becaufe women have little difcerning of virtue, but of fortune.

2ui celat delictum, quarit amicitiam; Sed qui altero fermone repetit, Separat foederatos. ${ }^{52}$ Here caution is given, that reconcilement is better managed by an amnefty, and paffing over that which is paft, than by apologies and excufations.

In omni opere bono erit abundantia; ubi autem verba funt plurima, ibi frequenter egeftas. ${ }^{53}$ Here is noted, that words and difcourfe abound moft where there is idlenefs and want.

Primus in fua caufa juftus; fed venit altera pars, et inquiret in eum. ${ }^{5}$ Here is obferved, that in all caufes the firft tale poffefleth much; in fort that the prejudice thereby wrought will be hardly re-
49 Prov. xxii. 24.
52 xvii. 9.
50 xi. 29.
s3 $x i v .23$.
51 X. I.
st $x$ viii. 17 . 
moved, except fome abufe or falfity in the information be detected.

Verba bilinguis quafi fimplicia, et ipfa perveniunt ad interiora ventris. ${ }^{55}$ Here is diftinguifhed, that flattery and infinuation, which feemeth fet and artificial, finketh not far; but that entereth deep which hath how of nature, liberty, and fimplicity.

Qui erudit deriforem, ipfe fibi injuriam facit; et qui arguit impium, fibi maculam generat. ${ }^{56}$ Here caution is given how we tender reprehenfion to arrogant and fcornful natures, whofe manner is to efteem it for contumely, and accordingly to return it.

Da fapienti occafionem, et addetur ei fapientia. ${ }^{57}$ Here is diftinguifhed the wifdom brought into habit, and that which is but verbal, and fwimming only in conceit; for the one upon occafion prefented is quickened and redoubled, the other is amazed and confufed.

Quomodo in aquis refplendent vultus proppicientium, fic corda hominum manifefta funt prudentibus. ${ }^{58}$ Here the mind of a wife man is compared to a glafs, wherein the images of all diverfity of natures and cuftoms are reprefented; from which reprefentation proceedeth that application,

Qui fapit, innumeris moribus aptus erit..$^{59}$

Thus have I ftayed fomewhat longer upon thefe fentences politic of Salomon than is agreeable to the proportion of an example; led with a defire

55 Prov. xviii. 8.

58 xxvii. 19.

56 ix. 7.

57 ix. 9.

59 Ovid, de Art. Am. i. 760 . 


\section{ADVANCEMENT OF LEARNING.}

to give authority to this part of knowledge, which I noted as deficient, by fo excellent a precedent; and have alfo attended them with brief obfervations, fuch as to my underftanding offer no violence to the fenfe, though I know they may be applied to a more divine ufe: but it is allowed, even in divinity, that fome interpretations, yea, and fome writings, have more of the eagle than others; ${ }^{60}$ but taking them as inftructions for life, they might have received large difcourfe, if I would have broken them and illuftrated then by deducements and examples.

This wifdom beft drawn from hiftory.

Neither was this in ufe only with the Hebrews, but it is generally to be found in the wifdom of the more ancient times; that as men found out any obfervation that they thought was good for life, they would gather it, and exprefs it in parable, or aphorifm, or fable. But for fables, they were vicegerents and fupplies where examples failed: now that the times abound with hiftory, the aim is better when the mark is alive. And therefore the form of writing which of all others is fittelt for this variable argument of negotiation and occafions is that which Machiavel chofe wifely and aptly for government; namely, difcourfe upon hiftories or examples. For knowledge drawn frefhly, and in our view, out of particulars, knoweth the way beft to particulars again; and it hath much greater life for practice when the difcourfe attendeth upon the example, than when the example attendeth upon the difcourfe. For this is

60 i.e. foar higher than others. 
no point of order, as it feemeth at firft, but of fubftance: for when the example is the ground, being fet down in a hiftory at large, it is fet down with all circumftances, which may fometimes control the difcourfe thereupon made, and fometimes fupply it as a very pattern for action; ${ }^{61}$ whereas the examples alleged for the difcourfe' fake are cited fuccinctly, and without particularity, and carry a fervile afpect towards the difcourfe which they are brought in to make good.

But this difference is not amifs to be remembered, that as hiftory of Times is the beft ground for difcourfe of government, fuch as Machiavel Efpecially from biography. handleth, fo hiftory of Lives is the moft proper for difcourfe of bufinefs, as ${ }^{62}$ more converfant in private actions. Nay, there is a ground of difcourfe for this purpofe fitter than them both, which is difcourfe upon letters, fuch as are wife and weighty, as many are of Cicero ad Atticum, and others. For letters have a great and more particular reprefentation of bufinefs than either chronicles or lives. Thus have we fpoken both of the matter and form of this part of civil knowledge, touching negociation, which we note to be deficient.

But yet there is another part of this part, which differeth as much from that whereof we have fpoken as fapere and fibi fapere, the one moving

For fel:advancement this knowledge

61 Ed. I 605 has gaine-Mr. Spedding fuggefts ain-Edd. I629, 1633 , have aftion.

62 I have here followed Mr. Spedding's amendment of as for is, which is no doubt correct, and far the beft folution of the diffi. culty of the palfage in the original. 


\section{ADVANCEMENT OF LEARNING.}

gives much as it were to the circumference, the other to the power over Fortune.

centre. For there is a wifdom of counfel, and again there is a wifdom of preffing a man's own fortune; and they do fometimes meet, and often fever. For many are wife in their own ways that are weak for government or counfel; like ants, which is a wife creature for itfelf, but very hurtful for the garden. This wifdom the Romans did take much knowledge of: Nam pol fapiens, faith the comical poet, fingit fortunam $\sqrt{i} b i ; 63$ and it grew to an adage, Faber quifque fortuna propria; $;^{64}$ and Livy attributed it to Cato the firft, in boc viro tanta vis animi et ingenii inerat, ut quocunque loco natus efet fibi ipfe fortunam facturus videretur. ${ }^{65}$

This conceit or pofition, if it be too much declared and profeffed, hath been thought a thing impolitic and unlucky, as was obferved in Timotheus the Athenian, who, having done many great fervices to the eftate in his government, and giving an account thereof to the people, as the manner was, did conclude every particular with this claufe, And in this fortune had no part. ${ }^{66}$ And it came fo to pafs, that he never profpered in any thing he took in hand afterwards: for this is too high and too arrogant, favouring of that which Ezekiel faith of Pharaoh, Dicis, Fluvius eft meus et ego feci memet ipfum: 67 or of that which another prophet fpeaketh, that men offer facrifices to their nets and fnares $: 68$ and that which the poet expreffeth,

63 Plaut. T'rin. ii. 2. 48.

64 I have not met with this. It is attributed to Appius Claudius.

65 Liv. xxxix. 40.

67 Ezek. xxix. 3.

66 Plutarch, Sylla, c. 6.

68 Habak. i. 16. 
Dextra mihi Deus, et telum quod miffile libro, Nunc adfint! 69

for thefe confidences were ever unhallowed, and unbleffed: and therefore thofe that were great politiques indeed ever afcribed their fucceffes to their felicity, and not to their fkill or virtue. For fo Sylla furnamed himfelf Felix, not Magnus : fo Cæfar faid to the mafter of the fhip, Cefarem portas et fortunam ejus. 70

But yet neverthelefs thefe pofitions, Faber quifque fortunce fuc: Sapiens dominabitur aftris: 71 invia virtuti nulla eft via, ${ }^{2}$ and the like, being taken and ufed as fpurs to induftry, and not as ftirrups to infolency, rather for refolution than for prefumption or outward declaration, have been ever thought found and good; and are, no queftion, imprinted in the greatef minds, who are fo fenfible of this opinion, as they can fcarce contain it within. As we fee in Auguftus Cæfar, (who was rather diverfe from his uncle, than inferior in virtue, how when he died, he defired his friends about him to give him a plaudite, as if he were confcient to himfelf that he had played his part well upon the Atage. ${ }^{73}$ This part of knowledge we do report alfo as deficient: not but that it is practifed too much, but it hath not been reduced Of this ruling our For. tune great men are confcious. to writing. And therefore left it hould feem to any that it is not comprehenfible by axiom, it is

Faber Fortuna five de Ambitu vitc.

69 Virg. An. x. 773 .

70 Plutarch, Cajar.

$71 \mathrm{Mr}$. Spedding ftates that this quotation is afcribed by Cognatus to Ptolemy.

72 Ovid, Met. xiv. 1 I 3 .

73 Sueton. Vit. A:t. c. $99 \cdot$ 
requifite, as we did in the former, that we fet down fome heads or paffages of it.

Rules towards the making of one's fortune.

Wherein it may appear at the firft a new and unwonted argument to teach men how to raife and make their fortune; a doctrine wherein every man perchance will be ready to yield himfelf a difciple, till he fee the difficulty : for fortune layeth as heavy impofitions as virtue; and it is as hard and fevere a thing to be a true politique, as to be truly moral. But the handling hereof concerneth learning greatly, both in honour and in fubftance: in honour, becaufe pragmatical men may not go away with an opinion that learning is like a lark, that can mount, and fing, and pleafe herfelf, and nothing elfe; but may know that the holdeth as well of the hawk, that can foar aloft, and can alfo defcend and ftrike upon the prey: in fubftance, becaufe it is the perfect law of inquiry of truth, that nothing be in the globe of matter, which fhould not be likewife in the globe of cryftal, or form ; that is, that there be not any thing in being and action, which hould not be drawn and collected into contemplation and doctrine. Neither doth learning admire or efteem of this architecture of fortune, otherwife than as of an inferior work: for no man's fortune can be an end worthy of his being; and many times the worthieft men do abandon their fortune willingly for better refpects: but neverthelefs fortune, as an organ of virtue and merit, deferveth the confideration.

You muft Firft, therefore, the precept which I conceive be able to to be moft fummary towards the prevailing in for- 
tune, is to obtain that window which Momus did fee into require : it who feeing in the frame of man's heart men. fuch angles and receffes, found fault that there was not a window to look into them; that is, to procure good informations of particulars touching perfons, their natures, their defires and ends, their cuftoms and fafhions, their helps and advantages, and whereby they chiefly ftand: fo again their weakneffes and difadvantages, and where they lie moft open and obnoxious; their friends, factions, and dependencies; and again their oppofites, enviers, competitors, their moods and times,

Sola viri molles aditus et tempora noras $;^{75}$

their principles, rules, and obfervations, and the like: and this not only of perfons, but of actions; what are on foot from time to time, and how they are conducted, favoured, oppofed, and how they import, and the like. For the knowledge of prefent actions is not only material in itfelf, but without it alfo the knowledge of perfons is very erroneous : for men change with the actions; and whiles they are in purfuit they are one, and when they return to their nature they are another. Thefe informations of particulars, touching perfons and actions, are as the minor propofitions in every active fyllogifm; for no excellency of obfervations, which are as the major propofitions, can fuffice to ground a conclufion, if there be error and miftaking in the minors.

That this knowledge is poffible, Salomon is our furety; who faith, Confilium in corde viri tan-

${ }^{74}$ Lucian. Hermot. 20.

75 Virg. En. iv. 423. 
quam aqua profunda; Jed vir prudens exbauriet illud. ${ }^{6}$ And although the knowledge itfelf falleth not under precept, becaufe it is of individuals, yet the inftructions for the obtaining of it may.

Be therein flow of belief and diftruft.

We will begin, therefore, with this precept, according to the ancient opinion, that the finews of wifdom are nlownefs of belief and diftruft; that more truft be given to countenances and deeds than to words: and in words rather to fudden paffages and furprifed words than to fet and purpofed words. Neither let that be feared which is faid, Fronti nulla fides:ii which is meant of a general outward behaviour, and not of the private and fubtile motions and labours of the countenance and gefture; which as Q. Cicero elegantly faith, is Animi janua, the gate of the mind.is None more clofe than Tiberius, and yet Tacitus faith of Gallus, Etenim vultu offenfronem conjectaverat. ${ }^{79}$ So again, noting the differing character and manner of his commending Germanicus and Drufus in the fenate, he faith, touching his fafhion wherein he carried his fpeech of Germanicus, thus; Magis in ppeciem adornatis verbis, quam ut penitus fentire crederetur: but of Drufus thus : Paucioribus, fed intentior, et fida oratione: ${ }^{60}$ and in another place, fpeaking of his character of fpeech, when he did any thing that was gracious and popular, he faith, that in other things he was velut eluctantium verborum; but then again, folutius vero loquebatur quando fubveniret. 81 So that there is no fuch artificer of dif-

76 Prov. $x \times .5$.

78 De Petit. Conful. xi 44 .

80 Ibid. i. 52.

77 Juv. Sat. ii. 8.

79 'Гacit. Ann. i. I2.

si Ibid. iv. $3^{I}$. 
fimulation, nor no fuch commanded countenance, vultus $j u \int u s$, that can fever from a feigned tale fome of thefe fafhions, either a more flight and carelefs fafhion, or more fet and formal, or more tedious and wandering, or coming from a man more drily and hardly.

Neither are deeds fuch affured pledges, as that they may be trufted without a judicious confideration of their magnitude and nature: Fraus fibi Cautious in trufting to men's in parvis fidem praftruit, ut majore emolumento fallat: 82 and the Italian thinketh himfelf upon the point to be bought and fold, when he is better ufed than he was wont to be, without manifeft caufe. For fmall favours, they do but lull men afleep, both as to caution and as to induftry; and are, as Demofthenes calleth them, Alimenta focordia. ${ }^{83}$ So again we fee how falfe the nature of fome deeds are, in that particular which Mutianus practifed upon Antonius Primus, upon that hollow and unfaithful reconcilement which was made between them; whereupon Mutianus advanced many of the friends of Antonius: fimul amicis ejus prafecturas et tribunatus largitur: ${ }^{84}$ wherein, under pretence to ftrengthen him, he did defolate him, and won from him his dependences.

As for words, though they be like waters to phyficians, full of flattery and uncertainty, yet they

Watchiul as to their words.

82 Liv, xxviii. 42 .

83 See Mr. Spedding's note on the De Augm. Sc. (p. 68I), where thefe words are quoted with context, and traced through $H$. Wolf's tranflation of Dem. Pbil. i. - the Greek being fimply ż $\sigma \tau \iota$

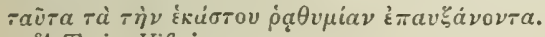

84 Tacit. Hift. is. 39 . 
are not to be defpifed, efpecially with the advantage of paffion and affection. For fo we fee Tiberius, upon a ftinging and incenfing fpeech of Agrippina, came a tep forth of his diffimulation, when he faid, rou are burt becaufe you do not reign; of which Tacitus faith, Audita bee raram occulti pectoris vocem elicuere; correptamque Graco ver $\int u$ admonuit, ideo ladi, quia non regnaret.85 And therefore the poet doth elegantly call paffions, tortures that urge men to confefs their fecrets:

Vino tortus et ira. ${ }^{\varepsilon 6}$

And experience thoweth, there are few men fo true to themfelves and fo fettled, but that, fometimes upon heat, fometimes upon bravery, fometimes upon kindnefs, fometimes upon trouble of mind and weaknefs, they open themfelves; efpecially if they be put to it with a counter-diffimulation, according to the proverb of Spain, $D i$ mentira, y facaras verdad (Tell a lie and find a truth.)

How reports of men at fecond hand fhould be received.

As for the knowing of men which is at fecond hand from reports; men's weakneffes and faults are beft known from their enemies, their virtues and abilities from their friends, their cuftoms and times from their fervants, their conceits and opinions from their familiar friends, with whom they difcourfe molt. General fame is light, and the opinions conceived by fuperiors or equals are deceitful; for to fuch men are more manked: Verior fama e domefticis emanat. ${ }^{8 T}$

85 Tacit. Ann. iv. 52 ; Suet. Vit. Tib. c. 53.

${ }^{86}$ Hor. Epift. 1. xviii. $3^{8 .}{ }^{87}$ Q. Cic. De Petit. Conful.v. 17. 
But the foundeft difclofing and expounding of you must men is by their natures and ends, wherein the weakeft fort of men are beft interpreted by their watch the natures and natures, and the wifeft by their ends. For it was both pleafantly and wifely faid, though I think very untruly, by a nuncio of the pope, returning from a certain nation where he ferved as lidger; whofe opinion being anked touching the appointment of one to go in his place, he wifhed that in any cafe they did not fend one that was too wile; becaufe no very wife man would ever imagine what they in that country were like to do. And certainly it is an error frequent for men to hoot over, and to fuppofe deeper ends and more compafs-reaches than are: the Italian proverb being elegant, and for the moft part true :-

\section{Di danari, di fenno, e di fede, Ce ne manco che non credi.}

There is commonly lefs money, lefs wifdom, and lefs good faith than men do account upon.

But princes, upon a far other reafon, are beft interpreted by their natures, and private perfons by their ends. For princes being at the top of human defires, they have for the moft part no particular ends whereto they afpire, by diftance from which a man might take meafure and fcale of the reft of their actions and defires; which is one of the caufes that maketh their hearts more infcrutable. ${ }^{88}$ Neither is it fufficient to inform ourfelves in men's ends and natures, of the variety of them only, but alfo of the predominancy, what 


\section{ADVANCEMENT OF LEARNING.}

humour reigneth moft, and what end is principally fought. For fo we fee, when Tigellinus faw himfelf out tripped by Petronius Turpilianus in Nero's humours of pleafures, metus ejus rimatur, ${ }^{89}$ he wrought upon Nero's fears, whereby he brake the other's neck.

Summary of But to all this part of inquiry the moft compenthis precept.

dious way refteth in three things : the firft, to have general acquaintance and inwardnefs with thofe which have general acquaintance and look moft into the world ; and efpecially according to the diverfity of bufinefs, and the diverfity of perfons, to have privacy and converfation with fome one friend at leaft which is perfect and well intelligenced in every feveral kind. The fecond is, to keep a good mediocrity in liberty of fpeech and fecrefy; in moft things liberty; fecrefy where it importeth; for liberty of fpeech inviteth and provoketh liberty to be ufed again, and fo bringeth much to a man's knowledge; and fecrefy, on the other fide, induceth truft and inwardnefs. The laft is, the reducing of a man's felf to this watchful and ferene habit, as to make account and purpofe, in every conference and action, as well to obferve as to act. For as Epictetus would have a philofopher in every particular action to fay to himfelf, Et hoc volo, et etiam infitutum fervare, 90

${ }^{89}$ Tacit. Ann. xiv. 57. Mr. Markby notices that Tacitus fpeaks " of the intrigues of Tigellinus againft Plautus and Sulla, by which he induced Nero to have both of them murdered. $\mathrm{Pe}$ tronius Turpilianus was put to death by Galba, folely becaufe he had enjoyed Nero's confidence. Vid. Tacit. Hift. i. 6."

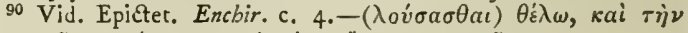

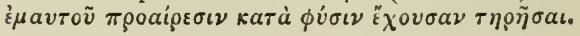


fo a politic man in everything fhould fay to himfelf, Et hoc volo, ac etiam aliquid addifcere. I have ftayed the longer upon this precept of obtaining good information, becaufe it is a main part by itfelf, which anfwereth to all the reft. But, above all things, caution muft be taken that men have a good ftay and hold of themfelves, and that this much knowledge do not draw on much meddling; for nothing is more unfortunate than light and rafh intermeddling in many matters. So that this variety of knowledge tendeth in conclufion but only to this, to make a better and freer choice of thofe actions which may concern us, and to conduct them with the lefs error and the more dexterity.

The fecond precept concerning this knowledge is, for men to take good information touching their own perfon, and well to underftand themfelves:

2. You mult know yourfelf well. knowing that, as St. James faith, though men look oft in a glafs, ${ }^{91}$ yet they do fuddenly forget themfelves; wherein as the divine glafs is the word of God, fo the politic glafs is the ftate of the world, or times wherein we live, in the which we are to behold ourfelves.

For men ought to take an impartial view of their own abilities and virtues; and again of their wants and impediments; accounting thefe with the moft, and thofe other with the leaft; and from this view and examination to frame the confiderations following.

Firft, to confider how the conftitution of their $\left(a_{0}\right)$ Seehow 91 St. James i. $2 \hat{3}, 24$. 
your charac- nature forteth with the general ftate of the times; ter agrees with the ge. neral ftate of affairs. which if they find agreeable and fit, then in all things to give themfelves more fcope and liberty; but if differing and diffonant, then in the whole courfe of their life to be more clofe, retired, and referved: as we fee in Tiberius, who was never feen at a play, and came not into the Senate in twelve of his laft years; whereas Auguftus Cæefar lived ever in men's eyes, which Tacitus obferveth, alia Tiberio morum via. ${ }^{92}$

(b.) Choofe, Secondly, to confider how their nature forteth accordingly, with profeffions and courfes of life, and accord-
the moft fuitable courfe of lite. ingly to make election, if they be free; and, if engaged, to make the departure at the firft opportunity: as we fee was done by Duke Valentine,,$^{93}$ that was defigned by his father to a facerdotal profeflion, but quitted it foon after in regard of his parts and inclination; being fuch, neverthelefs, as a man cannot tell well whether they were worfe for a prince or for a prieft.

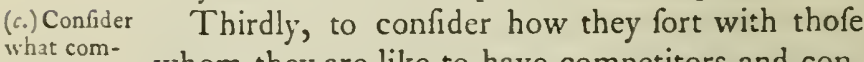
petition there may be; and avoid it. whom they are like to have competitors and concurrents; and to take that courfe wherein there is moft folitude, and themfelves like to be moft eminent: as Cæfar Julius did, who at firft was an orator or pleader; but when he faw the excellency of Cicero, Hortenfius, Catulus, and others, for eloquence, and faw there was no man of reputation for the wars but Pompeius, upon whom the ftate was forced to rely, he forfook his courfe be-

92 Tac, Ann. i. 54.

${ }^{9} \mathrm{Sc}$. Cæfar Borgia, fon of Alexander VI. See Guicciardini, vi. 3 . 
gun toward a civil and popular greatnefs, and tranfferred his defigns to a martial greatnefs.

Fourthly, in the choice of their friends and dependences, to proceed according to the compofition of their own nature : as we may fee in Cæfar; all whofe friends and followers were men active and effectual, but not folemn, or of reputation.

Fifthly, to take fpecial heed how they guide themfelves by examples, in thinking they can do as they fee others do; whereas perhaps their natures and carriages are far differing. In which error it feemeth Pompey was, of whom Cicero faith, that he was wont often to fay, Sylla potuitego non potero? 94 Wherein he was much abufed, the natures and proceedings of himfelf and his example being the unlikeft in the world; the one being fierce, violent, and preffing the fact; the other folemn, and full of majefty and circumitance, and therefore the lefs effectual.

But this precept touching the politic knowledge of ourfelves, hath many other branches, whereupon we cannot infift.

Next to the well underftanding and difcerning of a man's felf, there followeth the well opening and revealing a man's felf; wherein we fee nothing more ufual than for the more able man to make the lefs thow. For there is a great advantage in (3.) You muft take care to put yourfelf forward judicioufly. the well retting forth of a man's virtues, fortunes, merits; and again, in the artificial covering of a man's weakneffes, defects, difgraces ; ftaying upon the one, lliding from the other; cherihing the

(d.) In choice of friends, follow the bent of your own character.

(e.) Do not be led aftray by examples. 
one by circumftances, gracing the other by expofition, and the like: wherein we fee what Tacitus faith of Mutianus, who was the greateft politique of his time, Omnium qua dixerat feceratque arte quâdam oftentator: 95 which requireth indeed fome art, left it turn tedious and arrogant; but yet fo as oftentation, though it be to the firft degree of vanity, feemeth to me rather a vice in manners than in policy: for as it is faid, Audacter calumniare, femper aliquid haret $: 96$ fo, except it be in a ridiculous degree of deformity, Audacter te vendita, femper aliquid haret. For it will ftick with the more ignorant and inferior fort of men, though men of wifdom and rank do fmile at it, and defpife it; and yet the authority won with many doth countervail the difdain of a few. But if it be carried with decency and government, as with a natural, pleafant, and ingenious fafhion; or at times when it is mixed with fome peril and unfafety, as in military perfons; or at times when others are moft envied; or with eafy and carelefs paffage to it and from it, without dwelling too long, or being too ferious; or with an equal freedom of taxing a man's felf, as well as gracing himfelf; or by occafion of repelling or putting down others' injury or infolence; it doth greatly add to reputation: and furely not a few folid natures, that want this ventofity, and cannot fail in the height of the winds,

95 Tacit. Hif. ii. So.

$96 \mathrm{Mr}$. Spedding confiders that this comes from the advice given by Medius to Alexander's fycophants. - Plutarch, 2uomodo quis difcernere, Ëc. c. 24 . 
are not without fome prejudice and difadvantage by their moderation.

But for thefe flourifhes and enhancements of virtue, as they are not perchance unneceffary, fo it is at leaft neceffary that virtue be not difvalued and imbafed under the juft price; which is done in three manners: by offering and obtruding, a man's felf; wherein men think he is rewarded, when he is accepted; by doing too much, which will not give that which is well done leave to fettle, and in the end induceth fatiety; and by finding too foon the fruit of a man's virtue, in commendation, applaufe, honour, favour; wherein if a man be pleafed with a little, let him hear what is truly faid; Cave ne infuetus rebus majoribus videaris, $f$ bac te res parva ficuti magna delectat. 97

But the covering of defects is of no lefs importance than the valuing of good parts; which may be done likewife in three manners, by caution, by colour, and by confidence. Caution is when men do ingenioufly and difcreetly avoid to be put into thofe things for which they are not proper: whereas, contrariwife, bold and unquiet fpirits will thruft themfelves into matters without difference, and fo publifh and proclaim all their wants. Colour is, when men make a way for themfelves, to have a conftruction made of their faults or wants, as proceeding from a better caufe, or intended for fome other purpofe : for of the one it is well faid,

Sæpe latet vitium proximitate boni, ${ }^{98}$

and therefore whatfoever want a man hath, he 97 Cic, ad Heren. iv. 4. 98 Ovid, Art. Am. ii. 662.

And cover your defects neatly. 


\section{$296 A D V A N C E M E N T$ OF LEARNING.}

muft fee that he pretend the virtue that fhadoweth it; as if he be dull, he mult affect gravity; if a coward, mildnefs; and fo the reft : for the fecond, a man muft frame fome probable caufe why he fhould not do his beft, and why he hould diffemble his abilities; and for that purpofe muft ufe to diffemble thofe abilities which are notorious in him, to give colour that his true wants are but induftries and diffimulations. For confidence, it is the laft 99 but fureft remedy; namely, to deprefs and feem to defpife whatfoever a man cannot attain; obferving the good principle of the merchants, who endeavour to raife the price of their own commodities, and to beat down the price of others. But there is a confidence that paffeth this other; which is, to face out a man's own defects, in feeming to conceive that he is beft in thofe things wherein he is failing; and, to help that again, to feem on the other fide that he hath leat opinion of himfelf in thofe things wherein he is beft: like as we hall fee it commonly in poets, that if they how their verfes, and you except to any, they will fay, that that line coft them more labour than any of the reft; and prefently will feem to difable and fufpect rather fome other line, which they know well enough to be the beft in the number. But above all, in this righting and helping of a man's felf in his own carriage, he muft take heed he fhow not himfelf difmantled, and expofed to fcorn and injury, by too much dulcenefs, good-

99 i.e. the laft which thould be made ufe of; "impudens certe eft remedium, fed tamen, \&c." 
nefs, and facility of nature ; but thow fome fparkles of liberty, fpirit, and edge. Which kind of fortified carriage, with a ready refcuing of a man's felf from fcorns, is fometimes of neceflity impofed upon men by fomewhat in their perfon or fortune; but it ever fucceedeth with good felicity.

Another precept of this knowledge is, by all poffible endeavour to frame the mind to be pliant and obedient to occafion; for nothing hindereth 4. Be on the watch to feize oppor. men's fortunes fo much as this: Idem manebat, neque idem decebat, ${ }^{1}$ men are where they were, when occafions turn : and therefore to Cato, whom Livy maketh fuch an architect of fortune, he addeth, that he had verjatile ingenium. ${ }^{2}$ And thereof it cometh that thefe grave folemn wits, which muft be like themfelves, and cannot make departures, have more dignity than felicity. But in fome it is nature to be fomewhat vifcous and inwrapped, and not eafy to turn; in fome it is a conceit, that is almolt a nature, which is, that men can hardly make themfelves believe that they ought to change their courfe, when they have found good by it in former experience. For Machiavel noted wifely, how Fabius Maximus would have been temporizing ftill, according to his old bias, when the nature of the war was altered and required hot purfuit. ${ }^{3}$ In fome other it is want of point and penetration in their judgment, that they do not difcern when things have a period, but come in too late after the occafion; as Demolthenes ${ }^{4}$ compareth the

Cic. Brut. 95. (327.)

3 Mach. Difcorfi Jopra Livio, iii. 9.

2 Livy, xxxix. 40.

4 Demorth. Pbil. i. 51. 
people of Athens to country fellows, when they play in a fence fchool, that if they have a blow, then they remove their weapon to that ward, and not before. In fome other it is a lothnefs to leefe labours paffed, and a conceit that they can bring about occafions to their ply; and yet in the end, when they fee no other remedy, then they come to it with difadvantage; as Tarquinius, that gave for the third part of Sibylla's books the treble price, ${ }^{5}$ when he might at firft have had all three for the fimple. But from whatfoever root or caufe this reftivenefs of mind proceedeth, it is a thing mort prejudicial; and nothing is more politic than to make the wheels of our mind concentric and voluble with the wheels of fortune.

5. Sail with

Another precept of this knowledge, which hath the wind wherever poffible. fome affinity with that we laft fpake of, but with difference, is that which is well expreffed, Fatis accede Deifque, ${ }^{6}$ that men do not only turn with the occafions, but alfo run with the occafions, and not ftrain their credit or ftrength to over hard or extreme points; but choofe in their actions that which is moft paffable: for this will preferve men from foil, not occupy them too much about one matter, win opinion of moderation, pleafe the moft, and make a thow of a perpetual felicity in all they undertake; which cannot but mightily increafe reputation.

6. But do Another part of this knowledge feemeth to have not feem merely to fome repugnancy with the former two, but not as

${ }^{5}$ For the fame price, according to the Legend, Aul. Gell. i. 19. ${ }^{6}$ Lucan, viii. 486. 
I underftand it ; and it is that which Demofthenes follow ciruttereth in high terms; Et quemadmodum receptum cumftances. eft, ut exercitum ducat imperator, fic et a cordatis viris res ipfe ducenda; ut qua ipfis videntur, ea gerantur, et non ipji eventus tantum perfequi cogantur. ${ }^{7}$ For, if we obferve, we thall find two differing kinds of fufficiency in managing of bufinefs : fome can make ufe of occafions aptly and dexteroufly, but plot little; fome can urge and purfue their own plots well, but cannot accommodate nor take in $;^{8}$ either of which is very imperfect without the other.

Another part of this knowledge is the obferving a good mediocrity in the declaring, or not declaring a man's felf: for although depth of fecrecy, and making way, qualis eft via navis in mari, 9 7. Be neither too open nor too referved. (which the French calleth fourdes menées, when men fet things in work without opening themfelves at all,) be fometimes both profperous and admirable; yet many times diffmulatio errores parit, qui diffmulatorem ipfum illaqueant; and therefore, we fee the greateft politiques have in a natural and free manner profeffed their defires, rather than been referved and difguifed in them. For fo we fee that Lucius Sylla made a kind of profeffion, that he wifhed all men bappy or unbappy, as they food bis friends or enemies. So Cæar, when he went firft into Gaul, made no fcruple to profefs that he had rather be firft in a village, than

7 Demorth. Phil. i. 5 I.

B Explained by the Latin "qui occafiones qua opportune incidunt non arripiunt."

o Prov, xxx. Ig. 
fecond at Rome. ${ }^{10}$ So again, as foon as he had begun the war, we fee what Cicero faith of him, Alter (meaning of Cæfar) non recufat, fed quodammodo pofulat, ut, ut eft, fic appelletur tyrannus. ${ }^{11}$ So we may fee in a letter of Cicero to Atticus, that Auguftus Cæar, in his very entrance into affairs, when he was a darling of the fenate, yet in his harangues to the people would fwear, Ita parentis bonores confequi liceat, ${ }^{12}$ which was no lefs than the tyranny; fave that, to help it, he would ftretch forth his hand towards a ftatua of Cæfar's that was erected in the place: and ${ }^{13}$ men laughed, and wondered, and faid, Is it poffible? or, Did you ever hear the like? and yet thought he meant no hurt; he did it fo handfomely and ingenuounly. And all thefe were profperous: whereas Pompey, who tended to the fame end, but in a more dark and diffembling manner, as Tacitus faith of him, Occultior, non melior, ${ }^{1+}$ wherein Salluft concurreth, ore probo, animo inverecundo, ${ }^{15}$ made it his defign, by infinite fecret engines, to caft the ftate into an abfolute anarchy and confufion, that the ftate might caft itfelf into his arms for neceffity and protection, and fo the fovereign power be put upon him, and he never feen in it: and when he had brought it, as he thought, to that point, when he was chofen conful alone, as never any was, yet he could make no great matter of it, becaufe men underftood him not; but was fain, in the end, to go

10 Plutarch, Apopbtbegms.

12 Ad Att. xvi. 15.3 .

14 Tacit. Hift. ii. 38 .

11 Cic. ad Att. x. 4. 2.

13 I follow ed. 1605 in this paffage.

15 [Sueton.] de Clar. Gram. $\$ \times v$. 
the beaten track of getting arms into his hands, by colour of the doubt of Cæfar's defigns : fo tedious, cafual, and unfortunate are thefe deep diffimulations: whereof it feemeth Tacitus made his judgment, that they were a cunning of an inferior form in regard of true policy; attributing the one to Auguftus, the other to Tiberius; where fpeaking of Livia, he faith, Et cum artibus mariti fimulatione filii bene compofita: ${ }^{16}$ for furely the continual habit of diffimulation is but a weak and fluggifh cunning, and not greatly politic.

Another precept of this architecture of fortune is, to accuftom our minds to judge of the proportion or value of things, as they conduce and are material to our particular ends: and that to do fubftantially, and not fuperficially. For we thall

8. Be accuf. tomed to judge the relative values of things. find the logical part, as I may term it, of fome men's minds good, but the mathematical part erroneous; that is, they can well judge of confequences, but not of proportions and comparifons, preferring things of thow and fenfe before things of fubftance and effect. So fome fall in love with accefs to princes, others with popular fame and applaufe, fuppofing they are things of great purchafe: when in many cafes they are but matters of envy, peril, and impediment. So fome meafure things according to the labour and difficulty, or affiduity, which are fpent about them; and think, if they be ever moving, that they muft needs advance and proceed; as Cæfar faith in a defpifing 


\section{ADVANCEMENT OF LEARNING.}

manner of Cato the fecond, when he defcribeth how laborious and indefatigable he was to no great purpofe; Hac omnia magno fudio agebat. ${ }^{17}$ So in moft things men are ready to abufe themfelves in thinking the greateft means to be beft, when it fhould be the fitteft.

The beft order of means towards advancement.

As for the true marthalling of men's purfuits towards their fortune, as they are more or lefs material, I hold them to ftand thus: firft the amendment of their own minds. For the remove of the impediments of the mind will fooner clear the paffages of fortune, than the obtaining fortune will remove the impediments of the mind. In the fecond place, I fet down wealth and means; which I know moft men would have placed firft, becaufe of the general ufe which it beareth towards all variety of occafions. But that opinion I may condemn with like reafon as Machiavel ${ }^{18}$ doth that other, that moneys were the finews of the wars; whereas, faith he, the true finews of the wars are the finews of men's arms, that is, a valiant, populous, and military nation: and he voucheth aptly the authority of Solon, who, when Crœfus fhowed him his treafury of gold, faid to him, that if another came that had better iron, he would be mafter of his gold. In like manner it may be truly affirmed, that it is not moneys that are the finews of fortune, but it is the finews and fteel of men's minds, wit, courage, audacity, refolution, temper, induftry, and the like. In the third place 


\section{BOOK II.}

I fet down reputation, becaufe of the peremptory tides and currents it hath; which, if they be not taken in their due time, are feldom recovered, it being extreme hard to play an after game of reputation. And laftly, I place honour, which is more eafily won by any of the other three, much more by all, than any of them can be purchafed by honour. To conclude this precept, as there is order and priority in matter, fo is there in time, the prepofterous placing whereof is one of the commoneft errors: while men fly to their ends when they fhould intend their beginnings, and do not take things in order of time as they come on, but marhal them according to greatnefs, and not according to inftance; not obferving the good precept, 2uod nunc inftat agamus. ${ }^{19}$

Another precept of this knowledge is not to embrace any matters which do occupy too great a quantity of time, but to have that founding in a 9. Do nut follow what requires too man's ears,

\section{Sed fugit interea, fugit irreparabile tempus:20}

and that is the caufe why thofe which take their courfe of rifing by profeffions of burden, as lawyers, orators, painful divines, and the like, are not commonly fo politic for their own fortune, otherwife than in their ordinary way, becaufe they want time to learn particulars, to wait occafions, and to devife plots.

Another precept of this knowledge is, to imi- ro. Imitate tate nature, which doth nothing in vain; which nature.

19 Virg. Ecl. ix. 66.

20 Ib. Georg. iii. 284 . 


\section{ADVANCEMENT OF LEARNING.}

furely a man may do if he do well interlace his bufinefs, and bend not his mind too much upon that which he principally intendeth. For a man ought in every particular action fo to carry the motions of his mind, and fo to have one thing under another, as if he cannot have that he feeketh in the beft degree, yet to have it in a fecond, or fo in a third; and if he can have no part of that which he purpofed, yet to turn the ufe of it to fomewhat elfe; and if he cannot make anything of it for the prefent, yet to make it as a feed of fomewhat in time to come; and if he can contrive no effect or fubftance from it, yet to win fome good opinion by it, or the like. So that he fhould exact an account of himfelf of every action, to reap fomewhat, and not to ftand amazed and confufed if he fail of that he chiefly meant: for nothing is more impolitic than to mind actions wholly one by one. For he that doth fo leefeth infinite occafions which intervene, and are many times more proper and propitious for fomewhat that he fhall need afterwards, than for that which he urgeth for the prefent; and therefore men muft be perfect in that rule, Hac oportet facere, et illa non omittere. ${ }^{21}$

II. Secure a line of retreat from any courfe you follow.

Another precept of this knowledge is, not to engage a man's felf peremptorily in any thing, though it feem not liable to accident; but ever to have a window to fly out at, or a way to retire: following the wifdom in the ancient fable of the two frogs, which confulted when their plafh was 
dry whither they fhould go; and the one moved to go down into a pit, becaufe it was not likely the water would dry there; but the other anfwered, True, but if it do, how frall we get out again?

Another precept of this knowledge is, that ancient precept of Bias, conftrued not to any point of perfidioufnefs, but only to caution and moderation, Et ama tanquam inimicus futurus, et odi tanquam amaturus ;22 for it utterly betrayeth all utility for men to embark themfelves too far in unfortunate friendhips, troublefome fpleens, and childifh and humorous envies or emulations.

But I continue this beyond the meafure of an example; led, becaufe I would not have fuch knowledges, which I note as deficient, to be thought things imaginative or in the air, or an obfervation or two much made of, but things of bulk and mafs, whereof an end is hardlier made than a beginning. It muft be likewife conceived, that in thele points which I mention and fet down, they are far from complete tractates of them, but only as fmall pieces for patterns. And laftly, no man, I fuppofe, will think that I mean fortunes are not obtained without all this ado; for I know they come tumbling into fome men's laps; and a number obtain good fortunes by diligence in a plain way, little intermeddling, and keeping themfelves from grofs errors.

But as Cicero, when he fetteth down an idea of a perfect orator, doth not mean that every

22 Ariftot, Rbet, ii. 13.4. 
pleader hould be fuch; and fo likewife, when a prince or a courtier hath been defcribed by fuch as have handled thofe fubjects, the mould hath ufed to be made according to the perfection of the art, and not according to common practice: fo I underftand it, that it ought to be done in the defcription of a politic man, I mean politic for his own fortune.

All thefe rules are for the purfuit of good, not evil ends.

But it muft be remembered all this while, that the precepts which we have fet down are of that kind which may be counted and called Bonee Artes. As for evil arts, if a man would fet down for himfelf that principle of Machiavel, ${ }^{23}$ that a man Jeek not to attain virtue itfelf, but the appearance only thereof; becaufe the credit of virtue is a belp, but the ufe of it is cumber: or that other of his principles, that be prefuppofe, that men are not fitly to be wrought otberwife but by fear; and therefore that be feek to have every man obnoxious, low, and in frait, which the Italians call feminar fpine, to fow thorns: or that other principle, contained in the verfe which Cicero citeth, Cadant amici, dummodo inimici intercidant, ${ }^{24}$ as the triumvirs, which fold, every one to other, the lives of their friends for the deaths of their enemies: or that other proteftation of L. Catilina, to fet on fire and trouble ftates, to the end to fifh in droumy waters, and to unwrap their fortunes, $E_{g \circ}$ fi quid in fortunis meis excitatum fit incendium, id non aqua fed ruina reftinguam: ${ }^{25}$ or that other principle of Lyfander,

${ }^{23}$ Prince, c. $17,18$.

24 Pro Reg. Deiot. ix. 25.

25 Cic. fro Mur. xxv. (5I.) 
that children are to be deceived with comfits, and men with oaths : $: 6$ and the like evil and corrupt pofitions, whereof, as in all things, there are more in number than of the good: certainly with thefe difpenfations from the laws of charity and integrity, the preffing of a man's fortune may be more hatty and compendious. But it is in life as it is in ways, the fhorteft way is commonly the fouleft, and furely the fairer way is not much about.

But men, if they be in their own power, and do bear and fuftain themfelves, and be not carried away with a whirlwind or tempeft of ambition, ought, in the purfuit of their own fortune, to fet before their eyes not only that general map of the Nor fhould men only feek their fortunes, but remember higher world, that all things are vanity and vexation of $\int$ pirit, ${ }^{27}$ but many other more particular cards and directions : chiefly that-that being without wellbeing is a curfe-and the greater being the greater curfe; and that all virtue is moft rewarded, and all wickednefs molt punifhed in itfelf: according as the poet faith excellently:

Quæ vobis, quæ digna, viri, pro laudibus iftis

Præmia poffe rear folvi? pulcherrima primum Dî morefque dabunt veftri. ${ }^{28}$

And fo of the contrary. And, fecondly, they ought to look up to the eternal providence and divine judgment, which often fubverteth the wirdom of evil plots and imaginations, according to that Scripture, He bath conceived mifchief, and Shall bring

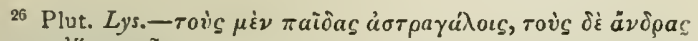

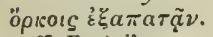

27 Eccl. ii. I I.

28 Virg. $A$ n. ix. 252. 


\section{ADVANCEMENT OF LEARNING.}

forth a vain tbing. ${ }^{29}$ And although men thould refrain themfelves from injury and evil arts, yet this inceffant and Sabbathlefs purfuit of a man's fortune leaveth not the tribute which we owe to God of our time; who we fee demandeth a tenth of our fubftance, and a feventh, which is more ftrict, of our time: and it is to fmall purpofe to have an erected face towards heaven, and a perpetual grovelling fpirit upon earth, eating duft, as doth the ferpent,

Atque affigit humo divinæ particulam auræ. ${ }^{30}$

And if any man flatter himfelf that he will employ his fortune well, though he fhould obtain it ill, as was faid concerning Auguftus Cæfar, and after of Septimius Severus, that either they fhould never bave been born, or elfe they fhould never bave died, ${ }^{31}$ they did fo much mifchief in the purfuit and afcent of their greatners, and fo much good when they were eftablifhed; yet thefe compenfations and fatisfactions are good to be ufed, but never good to be purpofed. And laftly, it is not amifs for men in their race toward their fortune, to cool themfelves a little with that conceit which is elegantly expreffed by the Emperor Charles the Fifth, in his infructions to the king his fon, That fortune bath fomewhat of the nature of a woman, that if She be too much wooed, She is the farther off. ${ }^{32}$ But this laft is but a remedy for thofe whofe taftes are

$29 \mathrm{Job} \times \mathrm{v}, 35$.

30 Hor. Sat. ii. 2. 79.

31 Aurel. Victor, Epit. i. for Auguftus; for Severus, fee his life by Lampridius.

32 See Ellis and Spedding on this in the De Augm. Bk. viii. 2. 
corrupted: let men rather build upon that foundation which is a corner-ftone of divinity and philofophy, wherein they join clofe, namely, that fame Primum quarite. For divinity faith, Primum quarite regnum Dei, et ifta omnia adjicientur vobis $:^{33}$ and philorophy faith, Primum quarite bona animi; cetera aut aderunt, aut non oberunt. And although the human foundation hath fomewhat of the fands, ${ }^{34}$ as we fee in M. Brutus, when he brake forth into that fpeech,

Te colui, Virtus, ut rem; at tu nomen inane es ;35

yet the divine foundation is upon the rock. But this may ferve for a tafte of that knowledge which I noted as deficient.

Concerning Government, ${ }^{36}$ it is a part of knowledge fecret and retired, in both thefe refpects in which things are deemed fecret; for fome things are fecret becaufe they are hard to know, and fome becaufe they are not fit to utter. We fee all governments are obfcure and invifible :

Totamque infufa per artus

Mens agitat molem, et magno fe corpore mifcet. ${ }^{37}$

Such is the defcription of governments. We fee the government of God over the world is hidden, inafmuch as it feemeth to participate of much ir-

33 Matth. vi. 33 .

34 So edd. 1629,1633 ; ed. 1605 has fame.

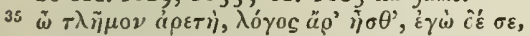

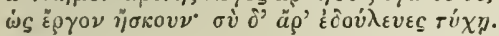

Dio CaJ. xlvii. 49 :

${ }_{36}$ This upon Government is very differently given in the Latin; the main fubject is poftponed; and two defiderata are difcuffedthe queftion of Enlarging an Empire, and that of Univerfal Juftice. 37 Virg. IEn, vi. 726. 


\section{$310 A D V A N C E M E N T$ OF LEARNING.}

regularity and confufion: the government of the foul in moving the body is inward and profound, and the paffages thereof hardly to be reduced to demonftration. Again, the wifdom of antiquity, (the Thadows whereof are in the poets,) in the defcription of torments and pains, next unto the crime of rebellion, which was the giants' offence, doth detert the offence of futility, as in Sifyphus and Tantalus. ${ }^{38}$ But this was meant of particulars : neverthelefs even unto the general rules and difcourfes of policy and government there is due a reverent and referved handling.

Should be declared as far as may be.

But contrariwife, in the governors toward the governed, all things ought, as far as the frailty of man permitteth, to be manifert and revealed. For fo it is expreffed in the Scriptures touching the government of God, that this globe, which feemeth to us a dark and hady body, is in the view of God as cryftal: Et in confpectu fedis tanquam mare vitreum fimile cryfallo. 39 So unto princes and fates, efpecially towards wife fenates and councils, the natures and difpofitions of the people, their conditions and neceffities, their factions and combinations, their animofities and difcontents, ought to be, in regard of the variety of their intelligences, the wifdom of their obfervations, and the height of their ftation where they keep fentinel, in great part clear and tranfparent. Wherefore, confidering that I write to a King that is a mafter of this fcience, and is fo well affifted, I think it decent to 


\section{BOOK II.}

pafs over this part in filence, as willing to obtain the certificate which one of the ancient philofophers afpired unto ; who being filent, when others contended to make demonftration of their abilities by fpeech, defired it might be certified for his part, that there was one that knew bow to bold bis peace.

Notwithftanding, for the more public part of government, which is laws, I think good to note only one deficiency; which is, that all thofe which have written of laws, have written either as phiDeficiency in Law Books; none are by ftatermen. lofophers or as lawyers, and none as ftatefmen. As for the philofophers, they make imaginary laws for imaginary commonwealths; and their difcourfes are as the ftars, which give little light, becaufe they are fo high. For the lawyers, they write according to the ftates where they live, what is received law, and not what ought to be law : for the wifdom of a lawmaker is one, and of a lawyer is another. For there are in nature certain fountains of juftice, whence all civil laws are derived but as ftreams : and like as waters do take tinctures and taftes from the foils through which they run, fo do civil laws vary according to the regions and governments where they are planted, though they proceed from the fame fountains. Again, the wifdom of a lawmaker confifteth not only in a platform of juftice, but in the application thereof; taking into confideration by what means laws may be made certain, and what are the caufes and remedies of the doubtfulnefs and incertainty of law; by what means laws may be made apt and eafy to be executed, and what are the impediments and 


\section{$312 A D V A N C E M E N T$ OF LEARNING.}

remedies in the execution of laws; what influence laws touching private right of meum and tuum have into the public ftate, and how they may be made apt and agreeable; how laws are to be penned and delivered, whether in texts or in acts, brief or large, with preambles, or without; how they are to be pruned and reformed from time to time, and what is the beft means to keep them from being too vaft in volumes, or too full of multiplicity and croffnefs; how they are to be expounded, when upon caufes emergent and judicially difcuffed, and when upon refponfes and conferences touching general points or queftions; how they are to be preffed, rigoroufly or tenderly; how they are to be mitigated by equity and good confcience, and whether difcretion and frict law are to be mingled in the fame courts, or kept apart in feveral courts; $D_{e}$ Pru. again, how the practice, profeffion, and erudition dentia legiflatoria, Jive de Fontibus furis. of law is to be cenfured and governed; and many other points touching the adminiftration, and, as I may term it, animation of laws. Upon which I infift the lefs, becaure I purpofe, if God give me leave, (having begun a work of this nature in aphorifms,) to propound it hereafter, noting it in the mean time for deficient.

And for your Majefty's laws of England, I could fay much of their dignity, and fomewhat of their defect; but they cannot but excel the civil laws in fitnefs for the government: for the civil law was non bos quafitum munus in $u$ us $;^{40}$ it was

10 Virg. Ann. iv. 647 . 
not made for the countries which it governeth: hereof I ceafe to fpeak becaufe I will not intermingle matter of action with matter of general learning.

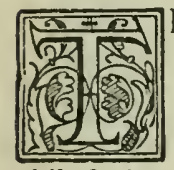

HUS have I concluded this portion of learning touching civil knowledge; and with civil knowledge have concluded human philofophy; and with human Conclufion of the Review of Philophilofophy, philofophy in general. And being now fophy. at fome paufe, looking back into that $I$ have paffed through, this writing feemeth to me, $f i$ nunquam fallit imago, ${ }^{41}$ (as far as a man can judge of his own work, not much better than that noife or found which muficians make while they are tuning their inftruments: which is nothing pleafant to hear, but yet is a caufe why the mufic is fweeter afterwards: fo have I been content to tune the inftruments of the Mufes, that they may play that have better hands. And furely, when I fet before me the condition of thefe times, in which learning hath made her third vifitation or circuit in all the qualities thereof-as the excellency and vivacity of the wits of this age; the noble helps and lights which we have by the travails of ancient writers; the art of printing, which communicateth books to men of all fortunes; the opennefs of the world by navigation, which hath difclofed multitudes of experiments, and a mals of natural hiftory; the leifure wherewith thefe times abound, not em- 


\section{$314 A D V A N C E M E N T$ OF LEARNING.}

ploying men fo generally in civil bufinefs, as the ftates of Græcia did, in refpect of their popularity, and the ftate of Rome, in refpect of the greatnefs of their monarchy; the prefent difpofition of thefe times at this inftant to peace; the confumption of all that ever can be faid in controverfies of religion, which have fo much diverted men from other fciences; the perfection of your Majefty's learning, which as a Phœnix may call whole vollies of wits to follow you; and the infeparable propriety of time, which is ever more and more to difclofe truth-I cannot but be raifed to this perfuafion that this third period of time will far furpass that of the Grecian and Roman learning : only if men will know their own ftrength, and their own weaknefs both; and take one from the other, light of invention, and not fire of contradiction; and efteem of the inquifition of truth as of an enterprife, and not as of a quality or ornament; and employ wit and magnificence to things of worth and excellency, and not to things vulgar and of popular eftimation. As for my labours, if any man thall pleafe himfelf or others in the reprehenfion of them, they fhall make that ancient and patient requeft, $V$ erbera, fed audi; 4 let men reprehend them, fo they obferve and weigh them: for the appeal is lawful, though it may be it hall not be needful, from the firf cogitations of men to their fecond, and from the nearer times to the times farther off. Now let us come to that learning, which both the

${ }^{42}$ Themiftocles to Eurybiades, Plut. Re $e_{5}$. et Imper. Apop.-

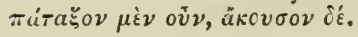


former times were not fo bleffed as to know, facred and infpired divinity, the Sabbath and port of all men's labours and peregrinations.

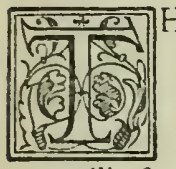

$\mathrm{HE}$ prerogative of God extendeth as well to the reafon as to the will of man; fo that as we are to obey His law, though we find a reluctation in our will, fo we are to believe His word, though we find a reluctation in our reafon. For if we believe only that which is agreeable to our fenfe, we give confent to the matter, and not to the author; which is no more than we would do towards a fufpected and difcredited witnefs; but that faith which was accounted to Abraham for righteournefs was of fuch a point as whereat Sarah laughed, ${ }^{43}$ who therein was an image of natural reafon.

Howbeit, if we will truly confider it, more worthy it is to believe than to know as we now know. For in knowledge man's mind fuffereth from fenfe; but in belief it fuffereth from fpirit, fuch one as it holdeth for more authorized than itfelf, and fo fuffereth from the worthier agent. Otherwife it is of the ftate of man glorified; for then faith fhall ceafe, and we fhall know as we are known.

Wherefore we conclude that facred theology, (which in our idiom we call divinity,) is grounded only upon the word and oracle of God, and not De Aug. Ix. 1. Of Theo-

logy. 
cnarrant voluntatem $D e i$ : but of that it is faid, $A d$ legem et teftimonium: fi non fecerint fecundum verbum iffud, ${ }^{45}$ \&c. This holdeth not only in thofe points of faith which concern the myfteries of the Deity, of the Creation, of the Redemption, but likewife thofe which concern the law moral truly interpreted: Love your enemies: do good to them that hate you; be like to your beavenly Father, that fuffereth bis rain to fall upon the juft and unjuft. ${ }^{46}$ To this it ought to be applauded, nec vox bominem fonat: ${ }^{47}$ it is a voice beyond the light of nature. So we fee the heathen poets, when they fall upon a libertine paffion, do ftill expoftulate with laws and moralities, as if they were oppofite and malignant to nature;

Et quod natura remittit, Invida jura negant. ${ }^{48}$

So faid Dendamis the Indian unto Alexander's meffengers, That be bad heard fomewhat of Pythagoras, and fome other of the wife men of Gracia, and that be beld them for excellent men: but that they had a fault, which was that they had in too great reverence and veneration a thing which they called law and manners. ${ }^{49}$ So it muft be confeffed, that a great part of the law moral is of that perfection, whereunto the light of nature cannot afpire: how then is it that man is faid to have, by the light and law of nature, fome notions and con-

45 Ifai. viii. 20.

46 Matth. v. 44.

47 Virg. ALn. i. 328.

48 Ovid, Met. x. 330.

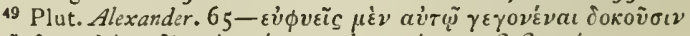

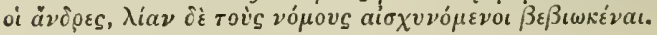


ceits of virtue and vice, juftice and wrong, good and evil? Thus, becaufe the light of nature is ufed in two feveral fenfes; the one, that which fpringeth from reafon, fenfe, induction, argument, according to the laws of heaven and earth; the other, that which is imprinted upon the fpirit of man by an inward inftinct, according to the law of confcience, which is a fparkle of the purity of his firft eftate; in which latter fenfe only he is participant of fome light and difcerning touching the perfection of the moral law : but how ? fufficient to check the vice, but not to inform the duty. So then the doctrine of religion, as well moral as myftical, is not to be attained but by infpiration and revelation from God.

The ufe, notwithftanding, of reafon in fpiritual things, and the latitude thereof, is very great and general : for it is not for nothing that the apoftle Reafon to be ufed in firitual calleth religion our reafonable fervice of God; ;0 infomuch as the very ceremonies and figures of the old law were full of reafon and fignification, much more than the ceremonies of idolatry and magic, that are full of non-fignificants and furd characters. But moft efpecially the Chriftian faith, as in all things, fo in this deferveth to be highly magnified; holding and preferving the golden mediocrity in this point between the law of the heathen and the law of Mahomet, which have embraced the two extremes. For the religion of the heathen had no conftant belief or confeffion, but left all to the liberty of argument; and the religion of

so Rom. xii. I. 


\section{ADVANCEMENT OF LEARNING.}

Mahomet, on the other fide, interdicteth argument altogether: the one having the very face of error, and the other of importure: whereas the faith doth both admit and reject difputation with difference. 1. In appre- The ufe of human reafon in religion is of two myfteries. forts: the former, in the conception and appre2. In deducing doctrine and direction. henfion of the myfteries of God to us revealed; the other, in the inferring and deriving of doctrine and direction thereupon. The former extendeth to the myfteries themfelves; but how? by way of illuftration, and not by way of argument: the latter confifteth indeed of probation and argument. In the former, we fee, God vouchfafeth to defcend to our capacity, in the expreffing of his myfteries in fort as may be fenfible unto us; and doth graft his revelations and holy doctrine upon the notions of our reafon, and applieth his infpirations to open our underftanding, as the form of the key to the ward of the lock: for the latter, there is allowed us a ufe of reafon and argument, fecondary and refpective, although not original and abfolute. For after the articles and principles of religion are placed and exempted from examination of reafon, it is then permitted unto us to make derivations and inferences from and according to the analogy of them, for our better direction. In nature this holdeth not; for both the principles are examinable by induction, though not by a medium or fyllogifm ; and befides, thofe principles or firft pofitions have no difcordance with that reafon which draweth down and deduceth the inferior pofitions. 
But yet it holdeth not in religion alone, but in many knowledges, both of greater and fmaller nature, namely, wherein there are not only pofita but placita; for in fuch there can be no ufe of abfolute reafon. We fee it familiarly in games of wit, as chefs, or the like: the draughts and firft laws of the game are pofitive, but how? merely ad placitum, and not examinable by reafon; but then how to direct our play thereupon with beft advantage to win the game, is artificial and rational. So in human laws, there be many grounds and maxims which are placita juris, pofitive upon authority, and not upon reafon, and therefore not to be difputed: but what is moft juft, not abfolutely but relatively, and according to thofe maxims, that affordeth a long field of difputation. Such therefore is that fecondary reafon, which hath place in divinity, which is grounded upon the placets of God.

Here therefore I note this deficiency, that there hath not been, to my underftanding, fufficiently inquired and handled the true limits and ufe of reafon in fpiritual things, as a kind of divine dialectic: which for that it is not done, it feemeth to me a thing ufual, by pretext of true conceiving Its limits not yet de. fined. De ufu legitimo ra. tionis his. mance in divinis. that which is revealed, to fearch and mine into that which is not revealed; and by pretext of enucleating inferences and contradictories, to examine that which is pofitive: the one fort falling into the error of Nicodemus, demanding to have things made more fenfible than it pleafeth God to reveal them, Quomodo polfit bomo nafici cum fit 


\section{ADVANCEMENT OF LEARNING.}

fenex? 51 the other fort into the error of the difciples, which were fcandalized at a thow of contradiction, Quid eft boc quod dicit nobis? Modicum, et non videbitis me; et iterum modicum, et videbitis me, \&c. ${ }^{52}$

Upon this I have infifted the more, in regard of the great and blefled ufe thereof; for this point, well laboured and defined of, would in my judgment be an opiate to ftay and bridle not only the vanity of curious fpeculations, wherewith the fchools labour, but the fury of controverfies, wherewith the church laboureth. For it cannot but open men's eyes, to fee that many controverfies do merely pertain to that which is either not revealed, or pofitive; and that many others do grow upon weak and obfcure inferences or derivations: which latter fort, if men would revive the bleffed Atyle of that great doctor of the Gentiles, would be carried thus, ego, non dominus $;^{53}$ and again, $\int e-$ cundum confilium meum, in opinions and counfels, and not in pofitions and oppofitions. But men are now over-ready to ufurp the ftyle, non ego, fed dominus; and not fo only, but to bind it with the thunder and denunciation of curfes and anathemas, to the terror of thofe which have not fufficiently learned out of Salomon, that the caufeless curfe fhall not come. ${ }^{54}$

Divinity has two parts.

Divinity hath two principal parts; the matter informed or revealed, and the nature of the infurmation or revelation: and with the latter we will

$$
\begin{array}{ll}
\text { s1 Joh. iii. 4. } & \text { s2 Joh. xvi. } 17 . \\
\text { s3 } 1 \text { Cor. vii. 12. } 40 . & \text { st Prov. xxvi. } 2 .
\end{array}
$$


begin, becaufe it hath moft coherence with that which we have now laft handled. The nature of the information confifteth of three branches; the limits of the information, the fufficiency of the information, and the acquiring or obtaining the information. Unto the limits of the information 1. The nature of the revelation. belong thefe confiderations; how far forth particular perfons continue to be infpired; how far forth the Church is infpired; how far forth reafon may be ufed: the laft point whereof I have noted as deficient. Unto the fufficiency of the information belong two confiderations; what points of b. Its fuffireligion are fundamental, and what perfective, being matter of further building and perfection upon one and the fame foundation; and again, how the gradations of light, according to the difpenfation of times, are material to the fufficiency of belief.

Here again I may rather give it in advice, than note it as deficient, that the points fundamental, and the points of farther perfection only, ought to De Gradibus unitatis in Civitate Dei. be with piety and wifdom diftinguifhed: a fubject tending to much like end as that I noted before; for as that other were like to abate the number of controverfies, fo this is likely to abate the heat of many of them. We fee Moles when he faw the Ifraelite and the Ægyptian fight, he did not fay, Why frive you? but drew his fword and flew the Egyptian: but when he faw the two Ifraelites fight, he faid, You are bretbren, why frive you? 55 If the point of doctrine be an सyptian, it muft be flain by the fword of the fpirit, and not recon- 


\section{$322 A D V A N C E M E N T$ OF LEARNING.}

ciled; but if it be an Ifraelite, though in the wrong, then, IVby frive you? We fee of the fundamental points, our Saviour penneth the league thus, He that is not with us, is againf us $;^{36}$ but of points not fundamental, thus, $H e$ that is not againft us, is with us. ${ }^{57}$ So we fee the coat of our Saviour was entire without $f e a m, 58$ and $f_{0}$ is the doctrine of the Scriptures in itfelf; but the garment of the Church was of divers colours, ${ }^{59}$ and yet not divided: we fee the chaff may and ought to be fevered from the corn in the ear, but the tares may not be pulled up from the corn in the field. ${ }^{60}$ So as it is a thing of great ufe well to define what, and of what latitude thofe points are, which do make men merely aliens and difincorporate from the Church of God.

c. Its acqui- For the obtaining of the information, it refteth fition by interpretation. upon the true and found interpretation of the Scriptures, which are the fountains of the water of life. The interpretations of the Scriptures are (r.) Me- of two forts; methodical, and folute or at large. thodical. For this divine water, ${ }^{61}$ which excelleth fo much that of Jacob's Well, is drawn forth much in the fame kind as natural water ufeth to be out of wells and fountains; either it is firft forced up into a ciftern, and from thence fetched and derived for ufe ; or elfe it is drawn and received in buckets and veffels immediately where it pringeth. The former fort whereof, though it feem to be the more ready,

56 Matth. xii. 30 .

57 Luke ix. 50.

58 Joh. xix. 23.

59 See Pf. xlv. 10, 14; or it may refer to Jofeph's coat of many colours-Gen. xxxvii. 3 .

60 Matth, xiii. 29.

61 Joh, iv. 13, If. 
yet in my judgment is more fubject to corrupt. This is that method which hath exhibited unto us the fcholaftical divinity; whereby divinity hath been reduced into an art, as into a ciftern, and the ftreams of doctrine or pofitions fetched and derived from thence.

In this men have fought three things, a fummary brevity, a compacted ftrength, and a complete perfection; whereof the two firft they fail to find, and the laft they ought not to feek. For as to brevity we fee, in all fummary methods, while men purpofe to abridge, they give caufe to dilate. For the fum or abridgment by contraction becometh obfcure; the obfcurity requireth expofition, and the expofition is diduced into large commentaries, or into common places and titles, which grow to be more vaft than the original writings, whence the fum was at firft extracted. So, we fee, the volumes of the fchoolmen are greater much than the firft writings of the fathers, whence the Mafter of the Sentences ${ }^{62}$ made his fum or collection. So, in like manner, the volumes of the modern doctors of the civil law exceed thofe of the ancient jurifconfults, of which Tribonian ${ }^{63}$

6.2 Peter Lombard received this name after writing a work entitled "The Sentences;" a fummary of Theology in four Books. The object of the work was the fettlement of all difputed doctrines by a collection of fentences from the Fathers. It is perhaps fuperfuous to add that the work has not as yet fulfilled its object. Still he deeply affected Theology, for he laid by it the foundations of the Scholaitic Philofophy. He was born at the beginning of the twelfth century; Bithop of Paris II 59; died II 4 .

63 Tribonian, Quæitor, Conful and Mafter of the Offices to Juftinian. With fixteen others he compiled the Digeft-promulyated it in 533. 


\section{ADVANCEMENT OF LEARNING.}

compileth the digeft. So as this courfe of fums and commentaries is that which doth infallibly make the body of feiences more immenfe in quantity, and more bafe in fubfance.

3 . Strength. And for ftrength, it is true that knowledges reduced into exact methods have a how of ftrength, in that each part feemeth to fupport and fuftain the other; but this is more fatisfactory than fubftantial: like unto buildings which ftand by architecture and compaction, which are more fubject to ruin than thofe which are built more ftrong in their feveral parts, though lefs compacted. But it is plain that the more you recede from your grounds, the weaker do you conclude: and as in nature, the more you remove yourfelf from particulars, the greater peril of error you do incur : fo much more in divinity, the more you recede from the Scriptures by inferences and confequences, the more weak and dilute are your pofitions.

r. Completenefs.

And as for perfection or completenefs in divinity, it is not to be fought; which makes this courfe of artificial divinity the more fufpect. For he that will reduce a knowledge into an art, will make it round and uniform : but in divinity many things muft be left abrupt, and concluded with this: $O$ altitudo fapientice et fcientice Dei! quam incomprebenfibilia funt judicia ejus, et non inveftigabiles vice ejus! ${ }^{4}$ So again the apoftle faith, $E x$ parte fcimus: ${ }^{65}$ and to have the form of a total, where there is but matter for a part, cannot be without fupplies by fuppofition and prefumption.

64 Rom. xi. 33.

65 I Cor. xiii. 9 . 
And therefore I conclude, that the true ufe of thefe fums and methods hath place in inftitutions or introductions preparatory unto knowledge : but in them, or by deducement from them, to handle the main body and fubftance of a knowledge, is in all fciences prejudicial, and in divinity dangerous.

As to the interpretation of the Scriptures folute and at large, there have been divers kinds intro(2.) Solute, or at large. duced and devifed; fome of them rather curious and unfafe than fober and warranted. Notwithftanding, thus much muft be confeffed, that the Scriptures being given by infpiration, and not by human reafon, do differ from all other books in the author: which, by confequence, doth draw on fome difference to be ufed by the expofitor. For the inditer of them did know four things which no man attains to know; which are, the myfteries of the kingdom of glory, the perfection of the laws of nature, the fecrets of the heart of man, and the future fucceflion of all ages. For Expofition muft be fober, becaufe God knows things hidden from us. as to the firt it is faid, He that prefeth into the light, Sall be oppreffed of the glory. And again, No man fhall fee my face and live. ${ }^{66}$ To the fecond, IVhen be prepared the beavens I was prefent, when by law and compass be inclofed the deep. ${ }^{67}$ To the third, Neither was it needful that any Sould bear witness to bim of man, for be knew well what was in man. ${ }^{68}$ And to the laft, From the beginning are known to the Lord all bis works. ${ }^{9}$

66 Exod. xxxiii. 20. "7 Prov. viii. 27 .
$\Leftrightarrow$ Acts $\times$ v. 18. 68 Joh. ii. 25. 


\section{ADVANCEMENT OF LEARNING.}

From the former two have been drawn certain fenfes and expofitions of Scriptures, which had need be contained within the bounds of fobriety; the one anagogical, and the other philofophical. But as to the former, man is not to prevent his time: Videmus nunc per fpeculum in anigmate, tunc autem facie ad faciem :io wherein neverthelefs there feemeth to be a liberty granted, as far forth as the polifhing of this glafs, or fome moderate explication to this ænigma. But to prefs too far into it, cannot but caufe a diffolution and overthrow of the fpirit of man. For in the body there are three degrees of that we receive into it, aliment, medicine, and poifon; whereof aliment is that which the nature of man can perfectly alter and overcome: medicine is that which is partly converted by nature, and partly converteth nature; and poifon is that which worketh wholly upon nature, without that, that nature can in any part work upon it. So in the mind, whatfoever knowledge reafon cannot at all work upon and convert is a mere intoxication, and endangereth a diffolution of the mind and underftanding.

But for the latter, it hath been extremely fet on foot of late time by the fchool of Paracelfus, and fome others, that have pretended to find the truth of all natural philofophy in the Scriptures; fcandalizing and traducing all other philofophy as heathenifh and profane. But there is no fuch enmity between God's word and His works; neither do they give honour to the Scriptures, as they fuppofe, 
but much imbare them. For to feek heaven and earth in the word of God, (whereof it is faid, Heaven and earth fhall pass, but my word fhall not $\mathrm{pa}\left(\mathrm{s}, \mathrm{7i}^{11}\right)$ is to feek temporary things amongft eternal: and as to feek divinity in philofophy is to feek the living amongit the dead, ${ }^{72}$ fo to feek philorophy in divinity is to feek the dead amongtt the living: neither are the pots or lavers, whofe place was in the outward part of the temple, to be fought in the holieft place of all, where the ark of the teftimony was feated. And again, the fcope or purpofe of the fpirit of God is not to exprefs matters of nature in the Scriptures, otherwife than in paffage, and for application to man's capacity, and to matters moral or divine. And it is a true rule, auctoris aliud agentis parva auctoritas; for it were a ftrange conclufion, if a man fhould ufe a fimilitude for ornament or illuftration fake, borrowed from nature or hiftory according to vulgar conceit, as of a Bafilifk, an Unicorn, a Centaur, a Briareus, an Hydra, or the like, that therefore he muft needs be thought to affirm the matter thereof pofitively to be true. To conclude, therefore, thefe two interpretations, the one by reduction or ænigmatical, the other philofophical or phyfical, which have been received and purfued in imitation of the rabbins and cabalifts, ${ }^{73}$ are to be confined with a noli altum Sapere, Jed time. ${ }^{i 4}$

71 Matth. xxiv. 35.

72 Luke xxiv. 5.

73 Cabalits - expounders of the Jewirh Cabala, or hidden fcience of divine myfteries, faid by the Rabbins to have been delivered to Mofes with the Law.

it Rom. xi. 20. 
But the two latter points, known to God and unknown to man, touching the fecrets of the heart, and the fucceffions of time, do make a juft and found difference between the manner of the expofition of the Scriptures and all other books. For it is an excellent obfervation which hath been made upon the anfwers of our Saviour Chrift to many of the queftions which were propounded to him, how that they are impertinent to the ftate of the queftion demanded; the reafon whereof is, becaufe, not being like man, which knows man's thoughts by his words, but knowing man's thoughts immediately, he never anfwered their words, but their thoughts: much in the like manner it is with the Scriptures, which being written to the thoughts of men, and to the fucceffion of all ages, with a forefight of all herefies, contradictions, differing eftates of the church, yea and particularly of the elect, are not to be interpreted only according to the latitude of the proper fenfe of the place, and refpectively towards that prefent occafion whereupon the words were uttered, or in precife congruity or contexture with the words before or after, or in contemplation of the principal fcope of the place; but have in themfelves, not only totally or collectively, but diftributively in claufes and words, infinite fprings and Atreams of doctrine to water the church in every part. And therefore as the literal fenfe is, as it were, the main ftream or river; fo the moral fenfe chiefly, and fometimes the allegorical or typical, are they whercof the church hath moft ufe; not that I wifh men to be 
bold in allegories, or indulgent or light in allufions: but that I do much condemn that interpretation of the Scripture which is only after the manner as men ufe to interpret a profane book.

In this part, touching the expofition of the Scriptures, I can report no deficience; but by way of remembrance this I will add : in perufing books of divinity, I find many books of controverfies; and many of commonplaces and treaties; a mafs of pofitive divinity, as it is made an art; a number of fermons and lectures, and many prolix commentaries upon the Scriptures, with harmonies and concordances : but that form of writing in divinity which in my judgment is of all others moft rich and precious, is pofitive divinity, collected upon particular texts of Scriptures in brief obfervations; not dilated into commonplaces, not chafing after controverfies, not reduced into method of art; a thing abounding in fermons, which will vanifh, but defective in books which will remain; and a thing wherein this age excelleth. For I am perfuaded, (and I may fpeak it with an $a b$ fit invidia verbo, ${ }^{75}$ and no ways in derogation of antiquity, but as in a good emulation between the vine and the olive, ) that if the choice and beft of thofe obfervations upon texts of Scriptures, which have been made difperfedly in Sermons within this your Majefty's inland of Britain by the fpace of thefe forty years and more, leaving out the largenefs of exhortations and applications thereupon, had been fet down in a continuance, it had been

Emanationes Scripturarum in doctrinas pofitivas. 
330 ADVANCEMENT OF LEARNING.

the beft work in divinity which had been written fince the Apoftles' times. 2. The The matter informed by divinity is of two formed by Divinity.

(r.) Of belief.

kinds ; matter of belief and truth of opinion, and matter of fervice and adoration; which is alfo judged and directed by the former : the one being (2.) Of fer- as the internal foul of religion, and the other as
vice. the external body thereof. And therefore the heathen religion was not only a worthip of idols, but the whole religion was an idol in itfelf; for it had no foul, that is, no certainty of belief or confeffion: as a man may well think, confidering the chief doctors of their church were the poets: and the reafon was, becaufe the heathen gods were no jealous gods, but were glad to be admitted into part, as they had reafon. Neither did they refpect the purenefs of heart, fo they might have external honour and rites.

But out of thefe two do refult and iffue four main branches of divinity; faith, manners, liturgy,

a. Faith. and government. Faith containeth the doctrine of the nature of God, of the attributes of God, and of the works of God. The nature of God confifteth of three perfons in unity of Godhead. The attributes of God are either common to the Deity, or refpective to the perfons. The works of God fummary are two, that of the creation and that of the redemption; and both thefe works, as in total they appertain to the unity of the Godhead, fo in their parts they refer to the three perfons : that of the creation, in the mals of the matter, to the Father; in the difpofition of the form, to the Son; 
and in the continuance and confervation of the being, to the Holy Spirit. So that of the redemption, in the election and counfel, to the Father; in the whole act and confummation to the Son; and in the application, to the Holy Spirit ; for by the Holy Ghoft was Chrift conceived in flefh, and by the Holy Ghort are the elect regenerate in fpirit. This work likewife we confider either effectually, in the elect; or privatively ${ }^{7}$ in the reprobate; or according to appearance, in the vifible church.

For manners, the doctrine thereof is contained b. Manners. in the law, which difclofeth fin. The law itfelf is divided, according to the edition thereof, into the law of nature, the law moral, and the law pofitive; and according to the ftyle, into negative and affirmative, prohibitions and commandments. $\mathrm{Sin}$, in the matter and fubject thereof, is divided according to the commandments; in the form thereof, it referreth to the three perfons in Deity: fins of infirmity againft the Father, whofe more fpecial attribute is power ; fins of ignorance againft the Son, whofe attribute is wifdom; and fins of malice againft the Holy Ghoft, whofe attribute is grace or lore. In the motions of it, it either moveth to the right hand or to the left; either to blind devotion, or to profane and libertine tranfgreffion; either in impofing reftraint where God granteth liberty, or in taking liberty where God

io. All old edd. have privately; but I cannot find that this word is ever uied as the fenfe of this paffage requires it, and fo have fubftituted privatively. 


\section{ADVANCEMENT OF LEARNING.}

impofeth reftraint. In the degrees and progrefs of it, it divideth itfelf into thought, word, or act. And in this part I commend much the deducing of the law of God to cafes of confcience; for that I take indeed to be a breaking, and not exhibiting whole of the bread of life. But that which quickeneth both thefe doctrines of faith and manners, is the elevation and confent of the heart ; whereunto appertain books of exhortation, holy meditation, Chriftian refolution, and the like.

c. Liturgy. For the liturgy or fervice, it confifteth of the reciprocal acts between God and man; which, on the part of God, are the preaching of the word, and the facraments, which are feals to the covenant, or as the vifible word; and on the part of man, invocation of the name of God; and under the law, facrifices; which were as vifible prayers or confeffions: but now the adoration being in Ppiritu et veritate, 77 there remaineth only vituli labiorum $;^{78}$ although the ufe of holy vows of thankfulnefs and retribution may be accounted alfo as fealed petitions.

$d$ Govern- And for the government of the church, it conment. fifteth of the patrimony of the church, the franchifes of the church, and the offices and jurifdictions of the church, and the laws of the church directing the whole; all which have two confiderations, the one in themfelves, the other how they ftand compatible and agreeable to the civil eftate.

This matter of divinity is handled either in form

77 John iv. 24.

${ }^{78}$ Hofea xiv. 2. 
of inftruction of truth, or in form of confutation of falfehood. The declinations from religion, befides the privative, which is atheifm, and the branches thereof, are three; Herefses, Idolatry, and $W$ itchcraft; herefies, when we ferve the true God with a falfe worfhip; idolatry, when we worthip falfe gods, fuppofing them to be true: and witchcraft, when we adore falle gods, knowing them to be wicked and falfe : for fo your Majefty doth excellently well obferve, that witchcraft is the height of idolatry. And yet we fee though thefe be true degrees, Samuel teacheth us that they are all of a nature, when there is once a receding from the word of God; for fo he faith, 2uafi peccatum ariolandi eft repugnare et quafi fcelus idololatria nolle acquiefcere. ${ }^{79}$

Thefe things I have paffed over fo briefly becaufe I can report no deficience concerning them: for I can find no fpace or ground that lieth vacant and unfown in the matter of divinity: fo diligent have men been, either in fowing of good feed, or in fowing of tares.

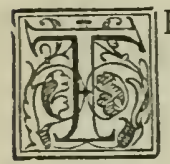

HUS have I made as it were a fmall Conclufion. globe of the intellectual world, as truly and faithfully as I could difcover: with a note and defcription of thofe parts which feem to me not conftantly occupate, or not well converted by the labour of man. In which, if I have in any point receded from that which is commonly received, it hath been with a purpofe 


\section{ADVANCEMENT OF LEARNING.}

of proceeding in melius, and not in aliud; a mind of amendment and proficience, and not of change and difference. For I could not be true and conftant to the argument I handle, if I were not willing to go beyond others; but yet not more willing than to have others go beyond me again: which may the better appear by this, that I have propounded my opinions naked and unarmed, not feeking to preoccupate the liberty of men's judgments by confutations. For in anything which is well fet down, I am in good hope, that if the firft reading move an objection, the fecond reading will make an anfwer. And in thofe things wherein I have erred, I am fure I have not prejudiced the right by litigious arguments; which certainly have this contrary effect and operation, that they add authority to error, and deftroy the authority of that which is well invented: for queftion is an honour and preferment to fallehood, as on the other fide it is a repulfe to truth. But the errors I claim and challenge to myfelf as mine own: the good, if any be, is due tanquam adeps facrificii, ${ }^{80}$ to be incenfed to the honour, firft of the Divine Majefty, and next of your Majefty, to whom on earth I am molt bounden.

Eo Ifiah xliii. 24. 


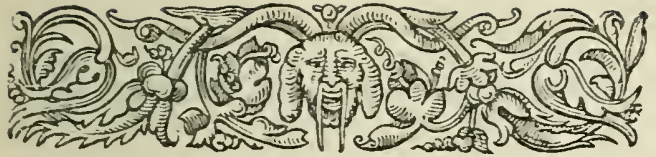

\section{GLOS S A R Y}

\section{OF WORDS EITHER OBSOLETE OR USED}

\section{IN SENSES NOT NOW ALLOWED.}

(The numbers refer to the paging.)

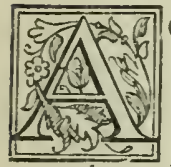

CCEPTION, ${ }_{3} 8,=$ acceptation.

Aсcоmmodate, 172, an adjective in ufe in

Bacon's day, but here equivalent to the participle and almolt $=$ adjufted.

verb to advene, which is alfo obfolete.

AfFECTS, $16_{3}$, = affections-not ufed here with any fenfe of infincerity.

AMBAGES, 137, I 54, "ambiguities of fpeech, fubterfuges, evafions :" Richardfon, who quotes Chaucer,-

"And but if Calcas lede us with ambages,

That is to faine, with double words llie, \&c."

Troil. and Crefs. Bk. v.

Bacon ufes the word according to its derivation-ambe

(a $\left.\mu \phi^{\prime}\right)$, agere (ayav) - "nature worketh by ambages," i.e. circuitous paths.

Antipodes, I9, of the dwellers on the other fide of the earth, not of that other fide itfelf. So Holland, Plinie, B. ii. c. 65,-"The Antipodes thould marvaile why we fell not down."

APPROMPT, 195, to itir up, quicken.

Aspersion, 58, 247, fprinkling, now ufed chiefly, if not entirely inetaphorically, and in a bad fenfe-then frequently in a good,-

"No lireet afperfions thall the heavens let fall."

$$
\text { SHares., Tempeft, iv. } 1 .
$$


Attend, 280, ufed actively,- "I have attended them with obfervations."

BIRD.WITTED, 228, incapable of continuous attention. Bp. Finher ufes the compound grofs-witted-Hall, fubtilwitted. (Not in Richardfon.)

BLANCH, 227, = blink, to avoid or evade; alfo $=$ blench. So Shakefpere, Meafure for $M$. iv. 5. "Do you blench from this?"

BRIBER, 277, here a receiver, not a giver, of bribes. This agrees with the origin of the word (fee Richardfon)be-reaver, or be-robber, the original ufage being = thief. So, as the word changed meaning, it became "a receiver of unlawful gain." Then in modern Englifh it is transferred to the agent who bribes.

CAPTION, 199, quibbling and deceit-ufed of fallacies. CARNosities, i 72, a mediæval term, for growth of flethy fubftances, as wens. (The word is not noticed in Richardfon.)

CAUTELS, 249, tricks and frauds-the word having drifted away from cautela, while caution has continued to reprefent the Latin. So Hall, Henry VI, anno $26,-{ }^{\circ} \mathrm{By}$ this praty cautele and light impolture was the town taken."

"So now no foil, nor cautel doth befmirch

The virtue of his will."-SHAKEs., Hamlet, i. 3 .

CEASE, 49, ufed tranfitively, " to ceafe progreffion," equivalent to "put a ftop to."

CENSURE, 312, , to be kept under cenforhip-not = blame. Ceremonies, I8 1,182 , ufed of fuperfitious ufages, intended to invoke the aid of fpirits. So Shakefpere, Ful. Caf. ii. 1 :-

"For he is fuperftitious grown of late,

Quite from the main opinion he held once

Of phantafy, of dreams, and ceremonies."

Civil ESTATE, 3 , condition as member of a sivitas. The higheft ufe of the term is now almoft, if not entirely, gone. See Trench, Glo/s. verbo. A "civil opinion," = received, $18 \mathrm{I}$.

Champaign, 150 , plain land-locus campeftris. In Bacon's day both a fubftantive and (as here) an adjective.

CIRCUMFER, I 30 , almoft = transfer, a rare verb, though its fenfe is plain enough, and its derivative common. 
COARCTATION, reftraint.

COEVALS, 122 , coincident in point of time-ufed as a fubftantive. Hakervill, Apologie, "taunted at by his coevals."

Colliguation, 142, melting-oppofed (by Sir T. Brown, Vulgar Errors, Bk. ii. c. I.) to coagulation.

COLUMBINE, 250 , dove-like-the innocency of the dove, as oppofed to "ferpentine wifdom." This is the only initance of the ufe of this adjective.

Compass, r $9^{2}$, = (now) a pair of compaffes. By the change of ufe we diftinguifh between this inftrument and the mariners' compafs.

COMPASS-REACHES, 289. This compound is not noticed in Richardfon. Its fenfe is that of roundabout fteps taken towards the accomplinment of any object reaching forth to compass it.

COMPLEXION, 203, = (probably) temperament or difpofition. The word has now been degraded from the inward parts of a thing or perfon to the tint of the outward couritenance. The tranfition is marked in Richardfon (quoting Cook's Voyages, vol. i. c. Io.) "without the leait appearance of what is called complexion"where he is fpeaking of a man's 1 kin as dead white, without colour.

CONFECTIONARY, 256 , the maker of confections, not the confections made. So I Sam. viii. I 3. "He will take your daughters to be confectionaries." The word confection is not rightly limited to fweet ftuff. Bacon here ufes it as equal to apothecary (a word formed in the fame manner) - and in mediæval Latin the apothecary was confectionarius. Comfit is derived from the fame fource.

Conscient, 283 , = conficious. Richardfon does not acknowledge the exiftence of this word; but, quoting the paffage whence it comes, alters it to confcious.

Consist In, $180,=$ depend upon. Richardfon quotes Ford-

"Tho' the ufe

Of fuch fet entertainments more confifts

In cultom, than in caufe; yet, \&cc.'

Contentation, = contentment.

Contestations, 27, = contefts, contentions.

Continent, 160 , = the whole extent of anything. So here "the continent of Nature" is "all that comes within the limits of Nature." 
Contristation, $6,=$ trouble or diftrefs. In Eccles. i. 18. the word which Bacon englifhes by contriftation, the Authorized Verfion renders grief.

Copie, 36, 37, 191, 205, = plenty-a French word imported into England in the fixteenth century. We ftill retain its adjective copious - and copy is really another form of the fame word, though its ufage is different. To copy is "copiam facere exferibendi," and perhaps carries us back to the days of the multiplication of "copies" of books by the hand.-See Dean Trench's Gloflary. There is a curious ufe of the word in p. 275 - "howfoever a man change copy, he can no ways quit himfelf well of it" (of contending with a fool.) The Latin fimply has "quocunque nos vertamus."

Corroborate, 26 , = itrong, matured.

DECARDED, I 57 , = difcarded-de or dis-carta, to throw away one's hand at cards. Richardfon quotes Macklin's Dumb Knight,-

"Indeed, mine are two queens, and one, I'll throw away-

Can you decard, madam ?"

Deducements, 2 So, = deductions.

DEFUNCT, I 85 , a fubftantive, now only ufed as an adjective.

DESIGNMENTs, 19 , = intentions.

Destituted, i6i, = abandoned.

Devote, 52, 二 devoted, (not devout, as one ed. reads it,) given up to any matter-then (efpecially) to the worhip of God.

Difficile, $270,=$ difficult.

Digladiation, 4 , = fencing, with fwords, properly: thence with fharp inftruments-as the tongue.

Dilatation, 146, power of expanfion. Bacon, in faying that God is "Holy in the defcription or dilatation of his works," feems to ufe thefe words as fynonyms, whereas they are more properly ufed, dilatation - of the expanfron of the thing itfelf; defcription-of the limitation of the thing by inveltigators.

Discourse, 35, 280, 281. See Trench's Gloffary. "Might have received large difcourfe," illuftration or invertigation of a fubject. So again, "difcourfe of government," "difcourfe of bufinefs," and "difcourfe of reafon," are all phrafes ufed by Bacon in the original fenfe of the 
word, fpringing out of the Latin difcurfus - the pafting from thought to thought, fubject to fubject; or, as in logic, from premife to conclution; and thence the word defcends to the modern ufage- of difcuffion by talk. There is a curious ufage of difcourfing in p. 147 , where Bacon ufes it (unlefs fome words have been omitted) as = final cauies.

DroumY, 306, = difturbed, troubled, " to firh in droumy, waters." The Latin has " in aquis turbidis pifcari", The word is not found in Richardfon's dictionary, nor can I trace its hiftory.

DulCENESS, 296, = fweetnefs. I find no other example of this libftantive, though dulcet and the verb to dulce are not uncommon in old writers. (This fubftantive is not in Richardfon.)

EASILIEST, 51, = moft eafily.

ElENCH, I98, a technical term-refutation of an arguinent or polition.

EMBASE, fee Imbafe.

ENABLEMENT, $98,=$ aid or means.

Estuation, 243 , = heat and commotion.

EXCEED, $16 \hat{3}$, = pafs beyond the bounds of moderationuled without a cafe after it.

EXPULSED, 216 , = expelled.

EXQUISITE, 44, =carefully fought out (not refined, as now.) EXTERN, I $31,248,257$, = foreign or outward.

EXTIRPER, 64 , = extirpator-the old verb being to extirf, not to extirpate.

FACTURES, 162, $171,=$ fathion or features of a thing. For the word feature is only another form of the word facture.

Fantastical, $35,=$ (in this place) falfe-bafed upon the fancy alone, without any bafis of fact or truth.

FLExuOUS, $14^{6},=$ bending and pliant.

FRIPPER, 220, = broker. We retain the word in our frippery-from frivolus, a feller of frivolous or worthlefs goods, See Trench's Gloffary.

GAMESTER, 246 , = player-not with the nightert fenfe of gambling. So in Shakefpere,"Sirrah, young gamefter, your father was a fool." Toming of the Shrew, ii. 1. 


\section{And,- \\ "You are a merry gamefter."-Henry VIII, i. 4.}

The word is ftill ufed in its right fenfe in the Weft of England.

Gigantine, 242, = gigantic, giant-like. (This adjective is not in Richardfon.)

GRAVELLED, 7 I, = ftuck or fet faft in gravel; then, embarraffed. So Shakefpeare, As you Like It, iv. I. "Gravelled for lack of matter." Dean Trench quotes the Rheims verfion of the Acts, xxvii. 4I, "When they were fallen into a place between two feas, they gravelled the fhip." The word has now paffed out of the original fenfe. Gravel is derived either from glareola or from gravare - the loading of thips for ballaft-or from to grave or dig out-(to grub) - a doubtful fuggeftion of Serenius. The firft feems to be the moft probable.

GROUND, 245, = an accompaniment with an infrument in mufic-the metaphor being fomewhat fimilar to that which would connect bafs with bafe or ground-floor of anything. The baflo part is fimply the low part-as diftinet from tenore, midway; alto, high ; foprano, above all. Thus bafs or ground would be the foundation on which all refts.

HOLDING OF, 3 , = pertaining to.

HuMOUR, HUMOROUS, 22, 62, 256. This word (Lat. humor, moifture) was originally ufed of the four "hu mours" of the body, blood, phlegm, choler, melancholy; it came to a morbid ftate of the mind arifing from excefs of thefe; and fo Bacon here ufes it; "the cenfure of humour, malignity, and pufillanimity" where it is not $=$ ill-humour in our fenfe, but rather $=$ a difeafed or jaundiced condition of mind. We apply the word in medicine to a moift difeafed ftate of the body :-in common language, to good and ill humour, or a cheerful or morofe condition of temper; - and to a quality of mind, difficult to define-a deep, almoft folemn, fenfe of the incongruities which coexift in the world. "The humorous man (i.e. the melancholy man) fhall end his part in peace."-Hamlet, ii. 2.

ILLAQUEATION, 198, $22 \mathrm{I}$, = entanglement. The chief part of the gloffary under this letter muft be taken up with Latin words which entered into our language, 
when learned men began to ufe it inftead of Latin for literary purpofes. The early part of the feventeenth century, under a pedantic king, was the time when this tranfition was moft marked. As the Englifh tongue gathered ftrength by greater ufe in philofophical writings, it threw off thefe excrefcences of unnatural words, and we are rid of confiderable numbers of them.

IMAGINANT, 164 , = perfon who imagines-a good word, though perhaps not now in actual ule.

IMBAR, $58,=$ bar or hinder.

IMBASE (or embafe), 46, 119, 157, 295, 327, = to lower, degrade; almolt $=$ debafe.

IMPERTINENT, I48, = out of place, according to the acceptance of the word among other writers.

Imposthumation, $\mathrm{I}_{22}$, = tumour or cyft formed in any part of the body by the humours withdrawn from the other parts.

IMPROFICIENCE, I47, = want or abfence of progrefs.

INCEPTION, 24I, 265 , = beginning.

INDIFFERENT, 27, = impartial. Thence it came naturally to $=$ moderate; thence, of courfe, lukerwarm and carelefs. So hard is it for one who feels to help being a partilan - and fo rare is a really impartial and judicial fpirit.

INFIRM, 198, = to deprive of Itrength. Ufed by Bacon as the oppofite of affirm. The method of Socrates, he fays, was to "infirm that which was affirmed by another."

INFLUENCE INTO, 312 , ufed in a fenfe of its derivation, as of one ftream flowing into another.

INGURGITATION, 7 3, =a greedy fwallowing. So Burton, Anatomy of Mel. (p. 235), has, "to eat and ingurgitate beyond all meafure."

INQUIRE, I 74, ufed as our " inquire into."

InSATISFACTION, 262 , = difappointment or abfence of fatisfaction.

Insinuation, 126 , = bending of onefelf, fo as to correfpond with the form of a thing-(not in a bad fenfe.)

INTEND, 272, 303, = attend to.

INTRINSIC, 47 , = internal (not as now $=$ real. )

INVENT, I 85 , = difcover (invenire); the wider ufe of the term, now limited to the productions of man's ingenuity and kill.

JOCULARLY, 178 , =pertaining to jugglery, to which form 
it has been contracted in courfe of time. The joculator in low Latin was the merry-andrew, or juggler (jocus.) JURISCONS ULTS, I06, = lawyers-profeffors of law ; being the Latin word fimply transferred into the Englin tongue.

LEESE, $46,90,95,224,247,298$. This is the old fpelling of the fame verb as "to lofe;" akin to it are $l 0 / 5$, le 5 , to loofe. In p. 46, Bacon ufes it as equivalent to wafte, or diminifh a thing; in pp. 9o, 224 , = to lofe. (So, too, the termination lejs comes from this verb-blamele $s$, \&c.) ; fo Germ. los, free.

LeVANT, THE, $3 \mathrm{I}$, = the Eaft, not part of the Mediterranean fea.

LIDGER, 289, = legate (a corrupt form of the word not noticed by Richardfon). In Bailey's Dict. it is fpelt ledger.

LikER, 75, = more likely.

LIMNED, 37, =illuminated the derivation being the fame.

LUsT, I 29, ufed by Bacon of Poefy, which " is as a plant that cometh of the luft of the earth"-fo ufed as nearly equivalent to its German meaning.

MACHINATION, 61 , = machine. The bad fenfe of the term is met with early. Richardfon quotes Sandy's Pfalms, p. 96,-

"How long will you machinate,

Magistral, 5 I, = our dogmatic.

Magistralities, 174. Magiftery was a term ufed by chemifts. Paracelfus defcribes it thus - " a preparation whereby the whole or very near the whole of any body, by the help of fome additament, greater or lets, is turned into a body of another kind." (BOYLE, Works, i. p. 637.) This explains Bacon's ufe of the term; but in p. 157 , he ufes it as almolt equivalent to dogmatifin.

MANIABLE, 2I, = manageable, tractable (through the French manier, from manus). This French form of the word never took root.

ManuRed, 104, 229. The fame word as mancuvreauvre into ure. To manure, then, is to work by hand, or cultivate - firft land, then intellects. Richardfon quotes Bihop Hall, who, in one of his Satires, Bk. v. Sat. i. fpeaks of "many a load of marle and manure." 
This brings in the modern ufage of the term-a very reftricted and debafed ufe.

Mirabilaries, ro8, works containing things marvellous. (?) Note-books of Marvels.

MOE, 27, 206. See Richardfon, v. More. Bacon ufes the word as a comparative. It is (according to the etymologifts) that which is mow-en, or mow-ed, into a heap (marvan, to mow, A. S.) Then mo; mo-er, (more); mo-eft, (moft.) Our much is a derivation of mo-mickle. The general ufe of the word is comparative and $=$ more.

MORAL, 32, = (perhaps) cuftomary-a Latinifed ufe " fecundum morem "- deriving the adjective from the fingular, not from the plural of mos.

Morigeration, 33, =complaifance or compliance ; " morem gerere alicui," to humour him.

Mought, г19, 121, 172, = might.

NON-PROMOVENT, 218. This is not Latin, as one edition feems to make it, but an Englinh word, formed after the type of fuch compounds as non-proficient, nonconforming, \&c. Bacon himfelf interprets it by " incurring into themfelves." The meaning is = " not advancing " as are arguments in circulo.

OCCUPATE, $165,=$ occupy. Ufed as an adjective in 333 , $=$ occupied.

PAINFUL, 303, = painftaking, induftrious - here and elfewhere an epithet of the clergy.

Palliate, $172,=$ palliated, or mitigated.

Pantomimus, 169, the perfon, not the thing. See Trench's Glofary.

PARCEL, = part.

PARTICIPLES, $\mathrm{I}_{32}$, = partaking of more kinds than one; ufed generally and not folely of grammar.

PAscuIL, 7I, = pafquinade, or lampoon (from an image at Rome, to which libels and fatires were affixed).

PeDAnTES, 16,26 . This word was written thus by Bacon as a foreign word (Italian or Spanifh, probably the latter), newly introduced into the Englin tongue and not acclimatifed. It does not feem to carry its modern notion of affectation joined with learning, in the ufe Bacon makes of the word pedantical (p. 227). 
PERCASE, 260, = perchance.

PLY, 298. This word is again ufed as a fubftantive by Bacon in the Effay on Cuftom: "Late learners cannot fo well take the ply; except it be in fome minds, that have not fuffered themfelves to fix." Where we fee the fame fenfe as in the compound apply - the bending or turning the mind to any matter. In this paffage Bacon ufes the word as almoft = purpofe: "can bring occafion to their ply,"-i.e. "can bend circumftances to their fervice," \&c.

Popularity, 314, = populoufnefs. Sir T. Browne ufes populofity-which, ugly as it is, would be the more correet form of the word.

Pragmatical, 284, = officious, bufy-now folely "priggifh," - a word which perhaps comes from it. See Trench's Gloffary.

PRENOTION, 162, a fubdivifion of that part of human fcience which treats of the fympathy between mind and body. Alfo, 206, the procefs of marking off beforehand what has no connection with the fubject. Ufed by Bacon as one of the two "intentions" or means in the received Arts of Memory.

PREPOSTEROUS, 303, ufed in its exact fenfe of wrong order of things.

PrESENTION, I79, = prefentiment, or previous perception inwardly of that which is about to occur. (Not in Richardfon.)

Proficience, 95, 12I, 334, = a making of progrefs. (Profit is the farne word under another form.)

PROPRIETY, 5, 314, property in its logical fenfe.

Punctual, $3 \mathrm{I},=$ to a point-thence exact even to littlenefs; later confined to time only, in fenfe of accurate. See Trench's Gloffary.

Punto, 272, (Spanifh) = ceremony, punctilio. Another example of the Spanin connection with England about this period of our hiftory.

Purgament, I72, = that which purges or cleanfes.

QUIT, 275, = acquit. So in the Bible, A. V.- "Quit you like men." - I Cor. xvi. I3.

REDARGUTION, 104, 198, I99, = refutation.

RE-EDIFY, 70, = rebuild. The verb edify being ufed in its original fignification, as edifice ftill is. 
REGIMENT, 3, 164, 261, = rule, government (regimen)When did the technical ufe of the term for a body of men under ftrict government firft obtain ? Dryden ufes it.

Reintegrate, I38, 209, = re-eftablifh anew. (Not merely to renew, but to go back to the beginning-as Bacon ufes it of the term magia which he propoles to "revive and reintegrate," i. $e$. to bring back to its original fenfe.)

Reluctation, 56,234, 315, = refiftance. We ufe reluctant ftill, of one ftruggling againft what he diflikes, yet is driven to.

REMORA, 148 (remorare, mora), a little firh, as was thought, which, clinging to a thip's keel, ftayed her courfe. Thence metaphor of any hindrance.

"All fodainly there clove unto her keele A little firh, that men call remora,

Which ftopt her courfe, and held her by the heele, That winde nor tide could move her thence away." SPENSER, The World's Vanitie.

Remove, 302, = removal.

RESPECTIVE, 2 , = refpectful (almoft)-more exactly, having due refpect or regard to the worth of the perfon dealt with. The honour which would be respective to a king would fcarcely be respective to a fquire.

$\mathrm{SAD}, 274$, = grave, firm, and fixed ; derived from the A.S. $\int a t-$ fo that fad is that which is fet or fixed; then grave or fedate; then ferious, mournful. See Trench's GlofJary. SAKE, 44 (if the reading be correet), either $=$ fide (which has been fuggefted as an emendation), or = queft - following its derivation from the verb feek, " on the other fake" would then be "on the other fide of the inveftigation," referring to Ariftotle's two treatifes-one on Natural Hiftory, the other (attributed to him) of Prodigies, \&c.

SAPIENCE, 55 , = wifdom.

SCHOLASTICAL, $74,=$ pedantic, not neceflarily in a bad fenfe.

SECURED, = free from care or hindrance (?).

SEEN, TO BE WELL, I 68, = to be efteemed.

SEGREGATE, 269 , as oppofed to congregate, or aggregatefeparated part from part. 
SEVER, To, 269, = to be disjoined, or diffevered; "feldom meet, and commonly fever."

SLUG, TO, I48, = to render fluggifh; flug is from the fame joot as low.

Solute, $322,=$ loofe and unreftrained.

SORT, 278,318 . "In fort that"-we now ufe "in fuch fort."

SortaBLE, 73, = agreeable to, correfponding with.

SPIAL, 100, = fpy. Shakefpere ufes efpial, Hamlet, iii. 1.

SPINosity, 184 , = pricklinefs, as of thorns.

Statua, 106, 252, 300, = ftatue. The Englin form was

in ufe long before Bacon's time, fo that he might as well have written it inftead of disfiguring his text with an unneceffary Latin word. Shakefpere (according to Collier and Knight) wrote ftatue, not fatua, in Fulius Cafar, iii. 2,- "Even at the bafe of Pompey's ftatua." STOND, 262. "Knots and flonds of the mind." Richardion fays it $=$ ftanding-place or ftation; ftay, ftop. It feems to be more like the joints and divifions of the ftem of a plant.

SUPPEDITATION, $25^{6}$, = fupport and fupply.

SURD, 317, almoit $=$ abfurd-i.e. without proper fignificance, "idolatry and magic, that are full of non-fignificants and furd characters." So in mathematics, furds are "roots incapable of being exhibited in a finite form," and incommenfurable.

SYNTAX, 227, = arrangement in relation to one another. Bacon ufes it of the "order or purfuit" in which ftudies may be undertaken.

TABLE, 72, = picture (tableau.) So Holland's Pliny, xxxv. c. 9. So Tablet (ibid.)

TARRASSE, 53 , = terrace. So fpelt, following the pronunciation, \&c. of the French terrafe, or of the Spanifh terrazo.

TAX, T0, 25, 30, 33, 168, 294, ufed abfolutely, (almolt = depreciated.) "The impolter is prized, and the man of virtue taxed." So Barrow, vol. iii. fer. 3,- "He was not like thofe mafters of philofophy, to frequently taxed and derided by the fatirifts." Is it equivalent to "taxed with folly," or (following the original fenfe), weighed, or rated, and found wanting? So Bacon ufes taxation, pp. 77, 128.

TERRENE, 60, = earthly. 
THEORY, 138 , ufed in the original fenfe of $\theta_{\text {expia }}$-invertigation, chiefly of things abitract.

THWART, 21, = perverfe, twifted. The verb to thwart is in general ufe, the adjective has now difappeared. The fubltantive thwart of a boat (crofs piece of board whereon the rowers fit), and athwart are alfo in ufe. A. S. thweorian, to wreft; thweort, pait participle. Shakefpere, King Lear, i. 4,- "And be a thwart difnatured torment."

Tractates, 305, = treatifes-we now have cut the word down to traft, and its meaning down to a flimfy or thort paper of a few pages. A tractate was a complete work on fome fpecial fubject.

TREACLE, 174, not our fyrup of molaffes, but a medicine compofed of viper's fleth, as an antidote to the viper's bite-fee note, p. 174 .

TrIVIAL, 2 1 7, =common and well-known:-not in Bacon's ufe $=$ worthlefs; but (according to its derivation) of things in the high-way, beaten down by many feet: the fenfe worthless is later. Richardfon notices the fimilarity of fenfe and found with trifle; but the words are not really connected.

TY POCOSMY, 220, =a figure or reprefentation of the world;

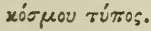

UNDERVALUE, 5, the verb is common enough,- - the fubfantive is not now in ufe. Bacon takes it in the fenfe of deficiency in worth: "what defects and undervalues I find in fuch particular acts."

UNPERFECT, II2, = imperfect.

UNPROPER, 50, = improper.

URE, 188, 2 14, (if this reading be allowed, inftead of $u f e$.) There are two derivations fuggefted-ufura, which is improbable; and cuvre, as manure from main, cuvre. The meaning is much the fame as that of $u f e$. Chaucer, Complaint of the Black Knight, ufes it thus:-

On his fortune and on ure alio."

i. e. fortune $=$ chance, and ure = labour, not of chance. So Milton, Paradife Loft, ufes the verb inure (or enure) not as derived from ure, but (as above) from ceuvre.

VASTNESS, 148 (vaftitudo), a wafte or defert-following 
the derivation of the word. (Richardion gives no example of this ufage of the term.)

Ventosity, 118, 294, = windinefs, or lightnefs, as of air.

VERDOR, 60, faid by Mr. Spedding to be a different word from verdure, but this feems to be very doubtful.

Vermiculate, 39. Bacon is drawing a comparifon between the corruption of fome folid fubftances into worms, and the tendency of found knowledge to putrify into idle and unwholefome "and, as I may term them, vermiculate queftions ;" where the word clearly fignifies queftions that are corruptions of knowledge, though fome notion of entanglement and intricacy may poffibly alfo enter in.

VOLLIES OF WITS, $3{ }_{4}$, = flights (as of birds) of men of learning and wifdom. This fenfe is rare, if not peculiar to Bacon. The ordinary meaning of difcharges of flying thot is at the bottom of all the paffages mentioned by Richardfon.

VOL UBLE, 298, volubility, 250 (volubilis), apt or eafy to roll-"voluble with the wheels of Fortune." Volubility is ufed by Bacon as an epithet of the ferpent. Now uled chiefly, if not entirely, of fpeech, and that too in rather a difparaging fenfe.

WHIFFLER, I90, = piper - connected with whiff, a flight breath of wind; alfo perhaps with waft-fuch a current of air as may be made by the waving of a fan(Richardfon.) Mr. Markby, very appofitely to the paftage in Bacon, quotes Shakefpere, King Henry $V$. v. (chorus) -

"The deep-mouthed fea,

Which, like a mighty whiffler before the king,

Seems to prepare his way." 


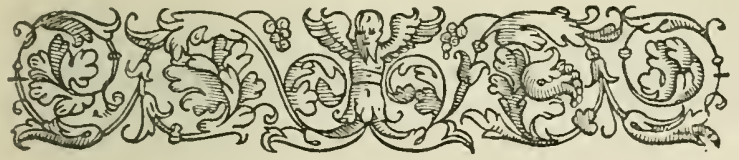

I N D E X.

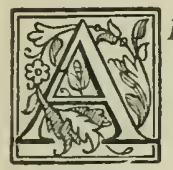

mar, 2 ro.

$B E L$, type of the contemplative ftate, 57. Abraham, 315. Academic philofophers, why popular, I9I. Acatalepfy in philofophy, 191 . Accidents of words, an appendix to gramAchilles, envied by Alexander becaufe he had a vates facer in Homer, 74; educated by Chiron, 128. ACAive good better than paffive, 240. Adonis, Venus' minion, 38 . Adrian, "mafter of thirty legions," 33 ; a learned prince and great inquirer, 69 ; curious as to Chriftianity, and hung up Chrift's picture in his gallery, $i b$.

Advancement of Learning, compared to the tuning of inAtruments before a concert, 3 I 3 . Efchines' fneer at Demofthenes, 20.

Affculapius and Circe, fable of, 168 ; he was the fon of the fun, 170.

IE $\int 0 p$, fable of the cock, $9 \mathbf{1}$; his fables are parabolical poefy, I27.

Affections, inquiry refpecting the, $25^{8}$; infufficiently han-

dled by the ancients, 259 ; beft treated by poets and hiftorians, $i b$. Agefilaus, 83 ; his fpeech to Pharnabazus, 26.

Agrippa, half a Chriftian, $7 \mathrm{I}$.

Agrippina, deteftable choice of, 91 ; ftung Tiberius by a fpeech, 288.

Akafuerus, his journals, 120 .

Albertus Magnus, too credulous in natural hiftory, 43.

Alchemifts depend on Vulcan, 99, I37.

Alchemy, 5I, related to imagination rather than reafon, 44; 
has a good aim, and has produced good refults, 45 ; furpaffed by natural prudence, I 53 .

Alexander Borgia's faying refpecting the French expedition, 155.

Alexander the Great, Ariftotle's fcholar, 14, 74 ; his expedition into Afia, 48, 83; his eftimate of learning, 74; his letter to Ariftotle, ib.; examples of his acutenefs, 75 ; his faying about Greek wars, 84; his allowance to Ariftotle for inquiry, 100 ; the journals of his houfe, I20; his title of prado, 140 ; fends meffengers to Dendamis the Indian, 316. Alexander Severus, 16,72.

Anabaptifts (of Munfter), their evil tenets, 238 . Analytics, their place in logic, 198.

Anatomy, too much neglected, I 7 r. Angels in a hierarchy, $5^{6}$; our knowledge of them limited,

136 ; fell by afpiring to be like GOD in power, 267 . Annals of Tacitus, 119 .

Anthropomorphites, herefy of the, 202.

Antipater, 76 ; a bad ruler, 77 .

Antipodes, 19.

Antiquities are hiftory defaced, III; of the world, II4. Antiquity worthipped by fome, 47 ; not to be neglected, I 39 ; "antiquitas freculi juventus mundi," $i b$.

Antitheta, or thefes argued pro and con., 225. Antoninus, Marcus Aurelius, his learning, 4, 7 I.

Antoninus Pius, molt learned, nicknamed rvuเvompirrss, 70 ;

became half a Chriftian, 71 ; his name how honoured after, $i b$. ; died a peaceful death, 173 .

Antonius over-reached by Mucianus, 287. Anytus, accufer of Socrates, 14.

Aphorifms are knowledge in growth, 49 ; compared with methodical writings, 2 I 4 .

Apollo ruled over mufic and medicine, 167.

Apollonius, 69.

Apophthegms, 124 ; Cæefar's, ib.; Solomon's, 27 f.

Apotheofis of the learned, 64 .

Appendices to hiftory, 124 .

Arabian philofophers too credulous in natural hiftory, 43 . Archimedes, 46.

Archite\&ure illuftrates man's perfonal relation with fociety, 246.

Ariofto's conceit of pothumous fame, 117.

Ariftippus' reply after having fallen at Dionyfius' feet, 33 . 
Arifotle, 46, 51; Alexander's tutor, 14; Dictator over the fchoolmen, 39; not too credulous, 44 ; mixes philofophy with logic, 50, 148; helped in his inquiries by Alexander, 100; his De Miris Aufcult., 108 ; on finall things, IIO; contradicts antiquity, 139 ; is too fond of final caules, 147; his Problemata a valuable work, 156 ; is compared to the Turkifl Sultan who murders his brethren, 157 ; notices the growth of obfervation in. children, $15^{8}$; wrote on prediction, 162 ; but not on gefture, $i b$.; on imagination $\left({ }^{*} p \xi \xi \xi s\right)$ and reafon, 183 ; on the mind, 185 ; derides the fophifts, 193 ; expounds the fable of Atlas, 197; on elenches, 198; on argument in a circle, 204; on fpeech, 207 ; taxes Democritus, 217 ; on rhetoric, 221 ; compares logic and rhetoric together, 224; his collections of figns of good and evil (in the topics), $i b . ;$ not well worked out, 225 ; faid that the young only can be happy, 233; his giving the firft place to the Bios $\theta$ soppritiós condemned by Chriftianity, 236 ; blames Herodicus, 239 ; on moral culture, 252 ; on magnanimity, 255 ; does not duly confider the relations of age, fortune, \&c., to morals, 257 ; but touches on thefe points in the Rhetoric, $i b . ;$ does not duly difcufs the affections, $25^{8}$; except cafually in the Rhetoric, 259 ; carelefs in his difcuffion as to cuftom and habit, $26 \mathrm{I}$; gives precepts for habituation, 262 ; caution required in training youth, $26_{3}$; on heroic or divine virtue, 266.

Arithmetic, I5r.

Arts, hiftory of, 109; calendar of them to be made, 154; their duty to exalt nature, 189 .

Afcham's veneration for Cicero and Demofthenes, 37.

Aftrology related to imagination rather than reaion, 44;

has a noble aim, $i b$.; divides men's natures according to the planets, $25^{6}$.

Aftronomy, can be explained either by the "received," or

by the Copernican hypothefis, 158.

Atalanta, 53.

Atheifm, how far encouraged by knowledge, $\mathbf{1} 2$.

Athletic art, 177 .

Atlas, fable of, how expounded by Ariftotle, 197.

Atticus, 300 ; his advice to Cicero on bearing, $27 \mathrm{I}$.

Auguftine, St., not fo great a teacher as ecclefiaftical hiftory is, 107.

Augujtus Cajar, his eloquence defcribed by Tacitus, 3; 
praifed by Virgil, 87 ; defired euthanafia, 173; requefted a plaudite when dying, 283 ; lived before men's eyes, 292 ; his feigned franknefs to the people, 300 ; hoped to employ well his ill-gotten fortune, 308 . Authority in fcience is too highly credited, 45,46 . Axioms applicable to more than one fcience, $132,133$.

Babel, $5^{8}$.

Bacon, Lord, promifes a work on Laws, 312.

Bafilifk, fable of the, 249.

Baths, medicinal, much neglected by phyficians, 175 .

Beafts get the credit of molt inventions, 186, 187 .

Behaviour is like a garment, 272 .

Bias, precept of, concerning friendhip, 305 .

Biography, II7; teaches beft the "wifdom of negociation," 281 .

Bird-zitted (or inattentive), people cured by mathematics, 228.

Blaefus, 229.

Books to be cherifhed in a Itate, 95 ; plentifu], but not good, 103.

Briareus, the hundred-handed, 128.

Brutus, Lucius, his act towards his fons, 251 .

Brutus and Cafius, their images abfent from Junia's funeral,

25 ; their fupper and difcourfe on tyrants, 251 ; Brutus' fpeech on fortune, 309 .

Bufiness, wifdom of, much neglected, 273,274 .

Cafar, Auguftus, (fee Augufus.)

Cafar, Fulius, (1ee Fulius.)

Cain, type of the active life, 57.

Calendar of knowledge to be made, I 54; and of doubts, 156 ; and of popular errors, 157.

Callifthenes attended Alexander, 74; his eloquence, 76.

Car, of Cambridge, almoft deified Cicero, 37.

Caracalla, $7 \mathbf{1}$.

Cardan, too credulous, 43 .

Cardinals, their temperaments noted in the accounts of conclares, 256 .

Carneades, ambaffador to Rome, 13.

Caffander, argued with Alexander, 76.

Cafius (and Brutus), their images not thown at Junia's funeral, 25 ; their fupper and difcuffion on alfafination of tyrants, 251 . 


\section{INDEX.}

Cafuiftry, cales of, in focial life, $250,251$.

Categories, their ufe, 200.

Catiline, 1 13 ; wifhed to "fifh in droumy waters," 306.

Cato the cenfor, wifhed to have no learning at Rome, 13 ; wifhed to learn Greek in his old age, 21 ; his judgment on his countrymen, 270; Livy's judgment on him, 282, 297.

Cato the fecond (of Utica), his errors in judgment, 19, 27, 28 ; praifed by Cicero, 252 ; cenfured by Cæfar, 302 .

Catulus, the orator, 292.

Caufes, the four, how inveftigated, 141 .

Celfus, condemned anatomia vivorum, 172 ; acknowledges that logic has nothing to do with medicine, 186.

Ceremonies (in the old fenfe) not lawful, I 82.

Chance gets the credit of moft inventions, 187 .

Characters of men to be ftudied by the moral philofopher, 255.

Charity, " the very bond of virtues," 266 ; admits of no excels, 267 .

Charles $V$. on fortune, 308 .

Charms, how fuppofed to act, $18 \mathrm{I}$.

Cherubim, angels of light, fecond in rank, $5^{6}$.

Che $\int s, 319$.

Chinefe characters, $\approx 07$.

Chiron, the centaur, Achilles' preceptor, $\mathbf{3} 28$.

Chriffianity, has fettled the queftion as to fummum bonum, 233 ; exalts focial above private good, 236 .

Chronicles, II 3 .

Chryfippus tried to interpret the fables of the poet, 129 ; followed a bad way of perfuading men to virtue, 222 .

Church, the, charged with the exceffes of heretics, 34 ; befriended learning, 61, 62 .

Church Hiftory too credulous, 43; how divided, 122.

Cicero, M. Tullius, 51, 188, 292, 306 ; had no refolution,

18; beft or fecond beft of orators, 22 ; hisphilofophy was adorned by eloquence, 38 ; on pofthumous fame, 118 ; his complaint againft Socrates, 160; an academic, 191 ; commends rhetorical preparations, 194; on rhetoric, 221 ; on faulty exercife of the faculties, 228 ; his Oratio pro Marcello, 249; praifes Cato the Second, 252 ; his judgment on Cato, 264 ; his interview with Cæfar, 271 ; fpeaks of the "profeffors of bufinefs" at Rome, 274; his Ad Atticum ufeful for wifdom of bufiA A 
nefs, $28 \mathrm{I}$; cenfures Pompey, 293 ; calls Cæefar tyrannus, 300 ; relates how Auguitus feigned franknefs, $i b$.; his perfect orator, 305 .

Cicero, Quintus, his advice to his brother as to his bearing, 271; his book De Petitione Confulatus, 274; calls the face animi janua, 286 .

Ciceronian ftyle revived at the Reformation, 35-37.

Ciphers, 2 10.

Circe and Efculapius, 168.

Civil Hiftory, I I ; knowledge, 270.

Clement VII, i $\delta$.

Cleon hated eloquence, 222 .

Coat of Chrift without a feam, 322.

Cobruebs of learning fpun by the fchoolmen, 39, 40 .

Columbus, 48 .

Commentaries, 112 ; in theology are bad, 323 .

Commodus, 7 I.

Common-place Books, prejudice againft, 205 ; their ufe, $i b$.

Conclaves, $25^{6 .}$

Confufion of tongues the fecond curfe of man, 209.

Confcience, a fparkle of man's original purity, 317 .

Conftantine nicknamed Trajan Parietaria, 70.

Contemplation, the beft itate, 55-57; Ariftotle placed it above active life, Chriftianity places it below it, 236 ; referved for God and angels, 237.

Contradictory initances not to be neglected in induction, I 89.

Controverfies in religion nearly extinet (fo Bacon hopes), 314 ; an affliction to the Church, 320 .

Copernicus' theory of aftronomy, 158, 161 .

Corruption of learning a great evil, 39 .

Coruncanius ufed to walk in the forum to be confulted on bufinels, 274 .

Cofmetic Art, 177 .

Cofmography, hiltory of, 120 .

Countenance, the, a tell-tale, 286.

Craterus, Alexander's friend, 77.

Credulity, akin to impolture, 42 .

Cretans, how judged by St. Paul, 257 .

Critics, advice to, 226, 227 .

Crafus' interview with Solon, 302.

Curius, 274.

Cuftody of knowledge, art of, 2 I4. 
Cuffom and habit, confidered as affecting moral acts, 260 , $26 \mathrm{I}$.

Cyrenaic fchool, wherein it placed happinefs, 238.

Cyrus Minor, II 3 .

Dadalus, 100.

Dancing anfwers to rerfifying, both being meafured, 210.

Darius, 74 .

De Petitione Confulatus of Quintus Cicero, the one work on bufinefs written ainong the ancients, 274 .

Death, preparation for, renders fear of it the greater, 245 .

Dedications of books to patrons fervile, 32.

Deeds of men not to be too much trufted by him who would make his fortune, 287 .

Defects of charaiter, how to be concealed, 295.

Definitions, neceffary before difcuffion, 203 .

Democritus, 46, I 57 ; of the truth of Nature, I 37 ; faid that there was no ruling mind in the univerfe, 148 ; his philofophy (as to phyfics) more found than A riltotle`s, ib.; bafed his philofophy on numbers, 150 ; taxed by Ariftotle, 217 .

Demofthenes, his reply to $Æ f$ chines, 20 ; counfel to the Athenians, 28 ; prepared beforehand prefaces for his orations, I 94 ; his examples of eloquence, $22 \mathrm{I}$; cares more for the right effect of eloquence than for praife, 232 ; rallied by Philocrates, 268 ; calls imall favours alimenta focordia, 287 ; his comparifon of Athens to a countryman fencing, 298 ; exhorts men to govern circumitances, 299.

Dendamis the Indian, 3 I 6 .

Diagoras the atheif, his wife reply, 201 .

Diafcordium, 174 .

Differences, the object of metaphylics, 143 .

Diogenes, his defence of philolophers (Arifippus, not Diogenes), 33 ; his interview with Alexander, 75 ; on felfreftraint, 239 .

Dionyfus had his ears in his feet, 33 ; his fpeech about philofophy, 4 r.

Dionyfus the Areopagite, $5^{6}$.

Diref7ion (or guidance), the chief help to learning, 94.

Divination, I 79 .

Divines have objected to learning, 6,7 .

Divinity, briefly difcuffed, 315 ; two chief parts, 320 ; four main branches thereof, 330 . 
Domitian's dream, 67 .

Donius, 159.

Doubt and fufpenfion of judgment wholefome, 51 ; thould always be regiftered, 156 .

Dreams, expofition of, the only true part of prenotion, 162 . Drufus, how commended by Tiberius, 286 .

Du-Bartas on flattery, 32 .

Duty, the good of man as regards fociety, 246 .

Eccentrics and epicycles, 158

Ecclefiafical Hiftory, too credulous, 43 ; a great teacher, 107 ; its divifions, $\mathbf{2 2}$.

Eden, man's labour in, really contemplation, 56 .

Education, honourable and important, 25 ; of youth, affects the character ever after, 229.

Egypt, a moft learned land, $5^{8}$; why fo few human figures in her temples, 187.

Egyptian prieft's judgment on the Greeks, 58; hierogly phics, 208.

Elenchs, a method of judgment, 198 ; how handled by Plato and Ariftotle, $i b . ;$ can be ufed to guard againft metaphorical ambiguities, 199.

Elizabeth, Qieen, and King James I, are Caftor and Pollux, 22 ; a moft learned princefs, 72 ; the glories and dangers of her reign, 73 ; her good government feen in its lafting effects, 93; her mafculine rule, 116 .

Elogies, barren, I I 7 .

Eloquence, fometimes defired above fenfe, $3^{6}$; not to be condemned, 38 ; bafed chiefly on imagination, 183 .

Emblem, one of the foundations on which the art of memory refts, 206.

Empedocles, I 57.

Empirics, in phyfic, 15 ; in ftatecraft, 16.

Ends of life muit be well chofen, 265 .

England, hiftory of, during Tudor period efpecially, i I5, I 6.

Enoch, the firft contemplative perfon, endowed the Church with prophecy, 237 .

Enquiry, power of wife, is the half of knowledge, 195.

Epaminondas, general and fcholar, 15 .

Epictetus' philofophy cenfured, 238 ; his precept on felfgovernment turned into one on felf-advancement, 290. Epicurus, his manner of death, 173; thought the gods to be of human hape, 202 ; wherein his fchool placed 
happinefs, $23^{8}$; held that virtue had much to do with it, 244.

Epifles are appendices to hiftory, 114.

Epitomes, the moths of hiftory, 112 .

Erafmus' colloquy of 'Fuvenis and Echo, 37.

Elays are ruminated hiftory, 120.

Ethics, ill-handled as yet, 231 ; how divided, 233 .

Euclid, 46 ; his propofitions feem Atrange till proven, 48 .

Euthanafia, much defired, 173.

Evil, knowledge of, neceffary, 249; arts, precepts of, 306 .

Exercifes at the Univerfities very defective, 102.

Experiment and inquiry, not fufficiently provided for, 99.

Experimental philosophy, I 52.

Exjtatic vifions, \&c., 180.

Extremes of novelty and antiquity to be avoided, 47 .

Ezekiel on Pharaoh's arrogance, 282.

"Faber quifque fortunæ fuæ," $282,283$.

Fabius Maximus would have carried on his policy too long, 297.

Fable of Ixion, 19; of the giants, 128 ; of Jupiter attacked

by the Gods, $i b$.; of the bringing up of Achilles, $i b$.; expounded, $i b . ;$ of the horfe-leeches, 277 ; of the frogs, 304 ; invented as fubftitutes for hiftorical examples, 280.

"FaEta non verba," 278.

Faith, its objects, 330 .

Fall of Man, how it came about, 57, 267; of angels, 267 .

Fallacies, 199, 200.

Falfity in fubftance a great fault, $38, \int q q$.

Fame, why created, according to the table, 128.

Fantafical learning, 35 .

Fafcination, 181 .

Fafting, retained under the Gorpel, $16_{4}$.

Felicity, what it is is determined by Chriftianity, 238 .

Final caufes, their ftudy mifplaced and mifdirected, 147.

Fire, how generated in the Weft Indies, 187.

Flattery, its groffnels, 32 ; fome inftances of it, $1-5,93$,

$94,310,314 ;$ mult be fine, if it is to fucceed, 279.

Forms, effential, their difcovery the object of metaphyfics,

143.

Forms of fubltances are infinite, 144.

Formula, or fet paffages, fit for different fubjects in rhetoric, 226. 
Fortune, good, hard to be borne wifely, 257; men can fafhion it for themfelves, 282 ; may be too much defpifed, $i b$.; rules for making one's, 284 , fqq.; lays as hard a burden on us as virtue does, $i b . ;$ not an end worthy of man's being, ib.; falls into fome men's laps, 305 .

Fracaftorius, I 59 .

Friends, caution in choofing, 278.

Frivolous learning, 35 .

Fulfilments of prophecy, gradual, 123.

Fundamental truths, 322 .

Galen makes too much of final caufes, 147 .

Gallus, 286.

Games, a part of civil life, 178 .

Geometry, 151 .

Germanicus and Drufus, how commended by Tiberius, 286.

Geftures often ftand inftead of fpeech, 207.

Gilbert, on the magnet, 51 ; revived the views of Xenophanes, I 59 .

$G O D$, His fecret things not to be reached by the fenfes, 10 ;

His word and His work both to be ftudied, II ; His power and wifdom, 55; His providence not impeached by the ftudy of other than final caufes, 149 ; to be imitated in His goodnefs and love, 267; His providence controls and changes evil counfels, $307 ; \mathrm{He}$ demands one-tenth of our fubftance, and one-feventh of our time, 308 ; fees all things clearly, 3 Io.

Godlines ranks before fortune, 309 .

Gold, the attempt to make it has caufed many inventions, 45.

Gonfalvo's fpeech to his foldiers at Naples, 239.

Good, nature of, 233 ; difcuffions as to fummum bonum are folved by Chriftianity, $i b . ;$ is either private or relative, 235 ; active or paftive, 240 ; that of the mind and that of the body are analogous, 269 .

Goodnature and its contrary, $25^{6}$.

Gordianus the younger, 16.

Government, carried on by acting on men's affections, 260; moves flowly, 270 ; a fecret part of knowledge, 309 ; of the Church, 332 .

Grammar, produced by the requirements of fpeech, 209; endeavours to remedy man's fecond curfe, $i b$. 
Greece and Rome, the two exemplar ftates, 114 .

Gregory, St., his hoftility againft learning, 62 ; his prayers for Trajan's foul, 68.

Guife, Henry Duke of, his ambition, 78.

Habituation, difcuffed, $26 \mathrm{I}$; precepts for, 262 , $\int q q$.

Hannibal thought little of Phormio's view's on war, 247.

Happine $s$, its nature, \&c., determined by Chriftianity, 238 ;

not to be fo purfued as to deftroy magnanimity, 245 .

Heathenifm has no fixed belief, 317 ; is, like an idol, foullefs, 330 .

Heliogabalus, 71 .

Henry VII, reign of, 116.

Henry VIII, reign of, I 6 .

Hephaftion, Alexander's friend, 77.

Heraclitus, the profound, his lumen ficcum, \&c., ro; his cenfure of intellectualiits, 50.

Hercules defpifed Adonis' image, 38 ; his pillars, 94.

Herefies, 333 .

Herillus, wherein he placed happinefs, 238 .

Hermes Trifinegiftus, 5.

Hermogenes, the rhetorician, 37.

Herodicus, blamed by Ariftotle, 239.

Heteroclites, or irregulars of pature, 107.

Hieroglyphics, 127, 208.

Hippocrates, 46 ; treated of prenotion, 162 ; kept notes of cafes, I7I; his aphorifm on ferious illnefs, 252 .

Hiftorians and poets have beft treated of the affections,

259.
Hiftory, related to memory, 105 ; divifions of, ro6; of learning, deficient, ib.; civil, I I 2 ; perfect, I I 3 ; modern, I I 4 , I 5 ; antiquities of, $i b$; of England, Tudor period, I 5 , I 6 ; ruminated, 120 ; ecclefialtical, how divided, I22; appendices to, I24; true, as compared with feigned (or poetry), 126.

Holy Spirit, His coming expreffed by the gift of tongues, $6 \mathrm{I}$; fin againft, 331 .

Homer's Iliad, viii. 19, alluded to, I2; how eftimated by Alexander, 74 ; has given a living to many, 88 ; his fame more lafting than that of conquerors, 90 ; a kind of fcripture to the later Greeks, 129.

Hope, the portion of all who undertake great things, 78 .

Horfe-leeches, fable of the, 277 .

Hortenfius, the orator, 292. 
Human philofophy, or felf-knowledge, 160 ; or humanity, I6r; its divifions, $i b$.

Humility, needed, but avoided, in things divine and human, I 90.

Idolatry, 333 .

"Idols" of the mind, 200 ; of the tribe, $i b . ;$ of the cave, 202 ; of the market-place, 203.

Images (in the Roman Church), how fuppofed to affect worihippers, I 8 I.

Imagination, how it affects the body, 164 ; its power between man and man, $18 \mathrm{I}$; hath two faces towards reafon and action, 182 ; in religion is above reafon, 183 ; affects judgment, 200.

Immortality, $9 \mathrm{I}$; that whereunto man's nature moft afpires, 89 ; children are a fort of, $i b$.

Impofture akin to credulity, $4^{2}$; its profeffors intoxicated by it, 87 .

Imprefion, a part of the fympathy between body and mind, 163.

Induction, as in ufe, cannot difcover arts, I88; natural anfwers better, 189 ; how judgment is applied to it, 196. Inquifitivenefs, akin to babbling, 42 .

Infight into men's characters needful to him who would make his fortune, 285 .

Inspiration, $32 \mathrm{I}$.

Inftinct of animals, 188 .

Invention of arts, 185 ; of fpeech, 192 ; placed after judgment by the fchoolmen, 193 ; art of it expands with it, 196.

Inventors, honoured by God before the flood, 57 ; deified by the ancients, 187 .

Italian proverb, 289 .

Italians, fufpicious of kind deeds, 287 .

Ixion, fable of, 19 ; interpreted, 153 .

Fames, St., quoted, $29 \mathrm{I}$.

Fames $I$, his praifes, $\mathrm{r}-5,93,94,310,314$; his fentiment as to geftures, 162 ; his book on a king's duty, 247 ; on the true law of free monarchies, 248 .

Fafon, the Theffalian, 83 ; his judgment on doing a little evil to bring about great good, $25 \mathrm{I}$.

Fefuits, their wifdom in education, 26 ; have much promoted learning, 62 . 
Ferveller's fkill in grinding precious ftones, 245.

Fob's quettion to his friends, 12; his learning, 59.

Fournals in hiftory, 119.

Fudge, a corrupt better than a facile, 277 .

Fudgment, acts of, 196 ; defined, 197 ; methods of, 198 ;

affected by the imagination, 200 .

fulian the emperor, interdicted Chriftians from learning,

61; his book entitled Cafares, 71 .

Fupiter, planet of civil fociety and action, 53; his chain, 135 .

Fuftinian, ultimus Romanorum, 14.

Kalendar. (See Calendar.)

Kindnefs, fometimes affumed to lull fufpicion and create idlenefs, 287.

Kings, to be regarded reverently, 31 ; if learned, are beft, 66 ; their duty, according to James I, 248.

Knowledge, only remembrance, according to Plato, 2 ; St.

Paul warns againft mifufe of, 6 ; bounds and limitations of it, so; does not lead, if found, to atheifm, Ix, 12 ; its ftrength in its connections, 40 ; hindrances to its growth, $47-54$; miftakes as to the ends of, 52 ; its true end, 53 ; thould produce fruit, 54 ; " a little knowledge is a dangerous thing," whence this faying comes to be attributed to Bacon, 84 ; it never palls, 89 ; feems immortal, even to atheifts, $9 \circ$; is as a pyramid, 145 ; has three Itages, 146 ; of ourfelves, 160 ; is continuous and entire, $i b . ;$ is pabulum animi, but ftill diftafteful to the carnal mind, 184 ; rational, 185 ; arts for attaining thereto are four, $185, \int q q$.

Lalius ufed to advife the Romans as to their affairs, 274 .

Languages, their ftudy revived at the Reformation, 35,36 ; are vehicula fcientia, $6 \mathrm{r}$.

Laws of England, 312 ; their fubject hitherto handled only by philolophers or lawyers, not by ftatefmen, $31 \mathrm{I}$; how

to be treated, 312; of nature, moral and pofitive, 33I. Lazuyers write of law as it is, not as it thould be, $3 \mathbf{I I}$. Learned men, their manners not neceffarily rude, 26, 27; apt to fix too high a ftandard, 27 ; their follies, $34, \int q q . ;$. to be cherifhed in a ftate, 95 .

Learning, flourifhes beft in company with arms, 15 ; of ufe to ftatefmen, $i b$.; does not caufe floth, 19 ; nor leffen refpect for law, 2 I ; not really difcredited by learned 
clowns, $i b$.; teaches men their fimallnefs, 29 ; its peccant humours, 47-54; purfued for mean ends, 52 ; is acquired knowledge, 55 ; its dignity, $55, \int 99 . ;$ cherifhed by the Church, 61 ; helps faith, 63 ; feats of, are faulty in feveral refpects, 97, 99. ; diftribution of, 105 ; three periods of, Greek, Roman, and XVI-XVII century, 3 I 3 ; divine, 3 I 5 .

Lectures, but ill provided for in places of learning, 98 .

Legends, too readily believed in the Church, 43.

Leprofy, the law refpecting, applied to morals, $5^{8}$.

Letters, like hips, carry wealth from age to age, 90 ; moft ufeful to teach wifdom of bufiners, 281 .

Levant, the, $3 \mathrm{I}$.

Lex Papia, 48 .

Libraries are thrines of true faints, 96 .

Life, how likely to be prolonged, 154 .

Light, firft created, 56 ; of nature, an infufficient guide, 3 I 5 , 316 ; ufed in two fenfes, 317 .

Liturgy or fervice, a part of divinity, 332 .

Livy, beft of hiftorians, 22 ; makes but little of Alexander, 48 ; his dictum on behaviour, $27 \mathrm{I}$; judgment on Cato the cenfor, $282,297$.

Lodejlone, why does it attract iron? 235 ; has only a limited power, $i b$.

Logic (and Rhetoric) too early ftudied at the Univerfities, ror ; difcuffes things in notion, hut confufedly, 13I; does not profefs to invent fciences, 186 ; the fyllogifin, what, 190; compared with Rhetoric, 223.

Longanimity, 255 .

Love, the very bond of all virtues, 266,267 .

Lucian, on the Stoic and the lap-dog, 32 ; his objection to the gods, who begat no children in his day, 48 .

Lucretius (quoted), 89 .

Lully, Raymond, his falfe method, 220.

Luther awakened all antiquity to help him, 35 .

Lyfander on the art of deceit, 306 .

Machiavelli on the poverty of the friars, 23 ; interprets the fable of Achilles and Chiron, 128; on the means of preferving governments, I 32 ; writes what is valuable as a warning, 249 ; on queftions of policy thuts his eyes to moral good and evil, 264 ; his form and fubject of writing the beft for civil prudence, 280 ; his note on the policy of Fabius Maximus, 297 ; on money as the 
"finews of war," 302 ; his precept as to the difadvantage of virtue, Sc., 306.

Magic, Natural, 18 I ; related to inagination rather than reafon, 44 ; has a noble aim, 45 ; Perfian, what it was, 132 ; its true fenfe, 138 ; prefent degradation, 152.

Magnanimity, 255 .

Mahomet's law regarded diet, Scc., I63; interdicts all argument and uie of reafon, 317,318 .

Man, a microcofin, $135,166$.

Manichoan herefy, 163 .

Manners (mores) in divinity, 331 .

Mariner's compafs, $155,186$.

Mafter of the fentences, 323 .

Mathematique, 149; divided into pure and mixed, 150 ; handmaid to many fciences, I 5 ; pure, valuable for mental training, to fix attention, 228 .

Medicine, fcience of, apt to be too empirical, $16_{1}$; difcuffed, 166 ; its uncertainty gives room for impolture, 167 ; is judged by its refults, ib.; analogous to morality in order of its invertigations, 258.

Memorials, or hiftory unfinifhed, 11 I, 112.

Memory, art of, 205.

Menander on love, 266 .

Menenius Agrippa, fable of, 98 .

Mental philofophy, how divided, I 78 .

Metaphyfique, ujed in fomewhat a different fenfe from its ordinary acceptation, I38; how limited, 140, I41 ; diftinguifhed from phyfics, I4I ; its functions, 143; abridges the multitude of particulars, 145 ; enfranchifes man's powers, 146.

Metellus, how addreffed by Cæfar, 81 .

Method, a hindrance to learning, 49 .

Method of tradition of arts, 212 ; its place in logic, $i b$.; of probation, 213 ; magiftral, $i b$. ; enigmatical, 214 ; compared with aphorifms, $i b ., 215$; varies according to different fubjects, 216 ; ufeful in limiting propofitions, 218 ; a falle kind of, 220.

Microcofm, man faid to be a, 135,166 .

Midas' judgment, 91 .

Mind, its nature, 178 ; functions, 182 ; is naturally full of fuperftition and impolture, 200; Georgics of the, 233 . Mirabilaries, 108.

Miracles, not conficlered among marvels, 109 ; not wrought for atheifts, but for the idolatrous and fuperftitious, 134 . 
Mifitheus, a pedant, ruled wifely, I6.

Mithridatum, 174 .

Mixed mathematics will extend as knowledge does, 151 .

Modern Hiftory, I14; times are truly the moft ancient, 47. Momus, wanted a window to look into men's hearts, 285.

Monaftic life, not good unlefs joined with action, 237 .

Money, not merely of gold and filver, 209 ; not the " finews of war," 302 ; its value for advancement, $i b$.

Monodica, many things in nature are fuch, $20 \mathrm{r}$.

Monftrofities, or marvels in nature, not fufficiently noted, 107.

Moral Philofophy, 251, fqq.; a wife handmaid to divinity, 252 ; mult confider what is poffible, 253; characters muft be ftudied by it, 254; fhould take note of age, fex, \&c., $256,257$.

Mofes, a learned man, $5^{8}$; on the mount, 237 ; a pattern for controverfialifts, 321 ; his law regulated queftions of diet, \&c., 163 .

Mofs, between putrefaction and a herb, 60 .

Mountebanks, often preferred to phyficians, 168.

Mufic, 245 ; cadences in, 133 .

Mufician, the, who held the foul to be a harmony, $5^{1}$.

Mutianus, overreached Antonius, 287; his character in Tacitus, 294 .

Myfteries, enveloped in "poefy parabolical," 127.

Naples, Gonfalvo at, 239.

Narrations of particular actions (monographs), I 18.

Narrownefs of mind a hindrance to learning, 50.

Natural Hiftory, 107 ; philofophy is of the mine and furnace, 137 ; how fubdivided, 138 ; magic, $i b . ;$ prudence, what, $151,152$.

Nature, book of God's works, 12, 63; helps us to underftand the Scriptures, $i b$. ; how divided, 142 ; her fummary law, 145; refufes to be enchained by fyllogifm, 190; light of, infufficient, 315,316 ; ufed in two fenfes, 317.

Negociation, part of civil prudence, 273.

Nero, in his minority governed by Seneca, 1 6, 28 .

Nerva, a good and learned prince, 67 .

Nicodemus, his error, 319 .

Novelty, to be avoided in extremes, 47 ; not to be diftrufted, ib.

Nuncio, the advice of a papal, 289. 


\section{INDEX.}

Olympian games, 177 ; vifited, according to Pythagoras, for many purpoles, 237.

Orations, appendices to hiftory, 124 .

Orators, compared with fophifs, I 99 ; ftir the paffions of republics, as the wind the lea, 258 .

Organs of fenfe and reflection akin, I 33 ; of the body, are they feats of correfponding mental faculties? 165 .

Orpheus' theatre, 65.

Ortelius of Antwerp, 219.

Oforius, his "watery vein," 37 .

Oftenfive reduction, 197 .

Ofentation, a fault of manners, not of policy, 294 .

Ottomans, the Sultan of the, lays his brethren at his acceffion, 157 .

Papia Lex, 48.

Paracelfus' philofophy reduced by Severinus, I 59 ; held that man is a microcofin, 166 ; exalted the imagination, 181; views of his fehool on theology, 326 .

Paris, judgment of, $9 \mathrm{I}$.

Parmenides, I 57 ; his fpeculation as to the ultimate unity of all things, 146 .

Parmenio's advice to Alexander, 77,78 .

Particulars, purfuit of, a hindrance to learning, 49 .

Paul, St., a learned man, 6I; wifhed himfelf anathema for his brethren, fo placing focial above perfonal good, 236; judgment on the Cretans, 257; his widdom, $3=0$.

"Pedantes," fuccefsful as governors, 16 ; ftyled the " apes of tyranny," 26.

Pedantical knorwledge, or how knowledge may be handed down to youth, 227,228 .

Percennius and Vibulenus, 229.

Periander's advice as to the preferving a tyranny, 208.

Perfian magic, 133 .

Phalynus, brought Artaxerxes' meffage to the Greeks, 82.

Pharaoh's arrogance, 282.

Philip of Macedon, how anfwered by a mufician, 69 .

Philo-fudaus, on knowledge, II.

Philocrates, 268.

Philopcemen, II4.

Philofopher, the, who carried the lap-dog, 32.

Philofophers too cautionary in their precepts, 244 ; not wife writers on laws, being too vifionary, $3 \mathbf{I}$. 
Philosophia prima, 49, 130; its character not fatisfactory, I 3 I ; defined, 132 .

Philofophy, mental, tends towards degeneracy, 46 ; related to reafon, 106 ; threefold-divine, natural, and human, I30; divine, I34; ancient, to be inveftigated, $15^{8}$; not to be treated as a profeffion, 239 ; moral, $25 \mathrm{I}, \int 9 q$. ; what part is in our power, 253 .

Phocion's obftinacy, 19.

Phormio's theory of wars, 247.

Phyjicians, if wife, will confider the effect of mind on body, 164 ; apt to undertake other arts befides medicine, 168 ; muft not defpair of cure, 173 ; muft endeavour to leffen pain, $i b$.

Phyfics, diftinguifhed from metaphyfics, 141 ; their functions difcuffed, $i b$, ; limited to the material with which they have to do, 146.

Phyfognomy, the only found part of prediction, $x 62$.

Pindar on fudden fortune, 257.

Pius Quintus, 17.

Places of learning to be helped by the ftate, 95 .

Plato, 46,58 ; his doctrine of remembrance, 2 ; would not bear office, 27; on Socrates, 31; adorned philofophy with his eloquence, 38 ; mixed philofophy with theo$\operatorname{logy}, 50,148$; held that kings fhould be philofophers, or philofophers kings, 66 ; derides men's contempt for common things, 109; held that forms are the true objects of knowledge, I43; his fpeculation as to the ultimate unity of all things, 146 ; makes too much of final caufes, 147 ; on the leats of the different faculties in the body, I65; commends middle propofitions in fciences, as fruitful, 186 ; his induction vicious, $188, \mathrm{I} 89$; faw the advantage of well-directed enquiry, 195; why he introduced Socrates and the fophifts, 198 ; his fuppofition of the cave, 202 ; defpiled rhetoric, 222 ; his faying as to the beauty of virtue, $i b$.

Platonifts mix philofophy with mathematics, 50.

Plautus, marvels at beneficence in old age, 257 ; (quoted), 282 .

Pleafure, how related to happinefs according to the ancients, 238.

Pliny, too credulous, 43 ; faved the Chriftians from perfecution, 69 ; his panegyric, 266.

Plutarch, adorned philofophy with his eloquence, $3^{8}$; has 
fagotted together the ancient philofophies unfatisfactorily, I 59 .

Poefy related to imagination, 105,183 ; is feigned hiftory, I2 5 ; compared with hiltory, 126 ; its effects even on barbarians, $i b$. ; its divifions, 127 ; fables of, have they an inward meaning? 129 ; regarded as to its form, 210 ; called vinum domonum by one of the fathers, 263 . Poets and hiftorians have beft handled the affections, 259 . Politicians, why they object to learning, 13 ; the corrupt fort of them feek only their own gain, 29.

Pompey, his faying when charged with the relief of Rome from famine, 236 ; wifely burned Sertorius' papers, 275 ; the only great captain when Cæfar began his career of war, 292 ; erred in following Sylla's example too far, 293 ; damaged himfelf by clofenefs, 300 .

Pofitive precepts of law and theology, 3 I9.

Poverty, its praifes fit fubject for friars, 23 ; honoured in the beft days of Rome, 24; "paupertas virtutis fortuna," $i b$.

Power, varies according to the degree and pofition of the governed, 86.

Preaching, foftered by the Reformation, 36 .

Predicaments (or categories), their ufe, 200.

Prediction and prenotion, arts referring to the connection between body and mind, 162 .

Prenotion, foundation to the art of memory, 206.

Preparation, as an inftrument for invention, 193.

Priefthood, of fome weight in empire, 88.

Princes, bett feen into by watching their natures, 289 .

Proclus and the Platonifts, 50.

Prometheus, his inventions, 187.

Promus and condus in Roman houfekeeping, 240.

Prophecy, is divine hiftory, 106, 122.

Proteus, III.

Proverb (Spanifh), 288 ; (Italian), 289.

Providence, hiltory of, 123.

Proxenus, Xenophon's friend, 82 .

Pygmalion's frenzy, 37.

Pythagoras bafed his philofophy on numbers, I 50 ; his

praife of a contemplative life, 237 .

Pythagorean fuperfitions as to diet, \&c., 163.

Quantity, the fubject of mathematics, 150 ; the moft abftract of all forms, $i b$. 
Quickness of difpatch molt ufeful for rifing in the world, 275. Quirites, 80.

Rabbins, their labours in the law, $5^{8}$; their interpretations to be reftrained, 327 .

"Ragioni di fato," 7 .

Ramus did well in reviving the rules of propofitions, 218 . Raven, the, his inftinct, 188.

Raymond, Lully, his falfe method, 220.

Readerfhips in fciences, thould be fo well endowed as to get the beft men, 98 .

Reajon, fubordinate to divine truth, 135 ; its exceffive application in "divine philofophy" likely to beget error, 136 ; but not to be neglected therein, 317 ; Chriftianity holds the mean as to it, $i b$.; ufe of it of two kinds, 318 ; not yet enough enquired into, 319.

Reduction in logic, of two kinds, oftenfive and ad abfurdum, 197.

Reformation, the, awakened learning, and a claffical ftyle, 35,62 .

Regifters, II 2.

Religion, deals with the impreffions of body on mind, 163 . Remedies, much confufed, I 74 .

Republics (like the fea), ftirred by any wind, $25^{8}$.

Revelation, 315, 316.

Reverence, a hindrance to learning, 50.

Rewards, a chief help to learning, 94 .

Rhetoric (and Logic) too early ftudied at the Univerfities, ror ; feparated from philofophy by Socrates, 160 ; engaged on imaginative reafon, 184 ; requires ftore of places (or topics), 194; difcuffed at length, 220; defined, 221 ; defpifed by Plato, $i b$. ; helps to keep the paffions in order, 223 ; compared with logic, $i b$.; Ariftotle's treatife thereon difcuffes the affections, 259.

Rhetorical jurprifes, akin to mufical, 133.

Romans, the, were profeffors of a wifdom of bufinefs, 274; their wifelt men ufed to walk in the forum giving advice to their fellow-citizens, $i b$.

Rome and Greece, the two exemplar ftates, 114 ; under the fix kings the prepared for her greatnefs, 229.

Romulus, 114 .

Salluft, on royal fancies, 257 ; cenfures Pompey's referved and dark ways, 300 . 


\section{INDEX}

Samuel, 189 .

Saracens, foes to learning, 62 .

Sarah, an image of natural reafon, 315.

Saturn, planet of reft, 53 .

Saviour, our, the great phyfician, I70; commends rhetorical preparation, 193.

Sayings, or brief fpeeches, appendices to hiftory, 124.

Scale or ladder of knowledge, 138 .

Sceptic philofophers had good grounds for becoming fuch,

I 9 I.

Schoolmafters held in too little honour, 25.

Schoolmen, the rudenefs of their ftyle, $3^{6}$; held in contempt

as barbarous, 37 ; their degenerate or "vermiculate"

learning, 39 ; their ufelefs fubtilty in matter and manner, 40 ; drew from their own minds, not from nature,

42 ; their voluminous writings, 323 .

Scornful, the, will not receive correction, 279.

Scotland, hiftory of, ill handled, I I 5 .

Scriptures, the, a well of life, 322 ; how interpreted, 323 ;

plentifully expounded in England, 329.

Sculptor, the, compared with Nature, 265.

Scylla, a type of fcholaftic learning, 4I.

Self-advancement, rules for, $284, \int q q$.

Seneca governed wifely during Nero's minority, 16, 28 ;

on weaknefs of character, 20 ; adorned philofophy with eloquence, 38 ; his fubtilty of mind, 40 ; compares fallacies to juggling tricks, 198 ; condemns eloquence for difplay, 232; feigned too high an elevation for man's nature, 234 ; complains that men care little for reformation of manners, 252 .

Seraphim, angels of love, the higheft order, $5^{6}$.

Sermons, in King James I.'s time, excellent, 329.

Serpent, his nature, 250.

Sertorius' papers burnt by Pompey, 275 .

Seven Sages, their fayings akin to poefy parabolical, 127.

Severinus the Dane, 159 .

Severus (Septimius) hoped to employ well his ill-gotten

fortune, 308.

Sextus Quintus, 7.

Sibyl, the, felling her books to Tarquin, 298.

Sin, its divifions, 33 I.

Sifyphus, his offence of futility, 310.

Sleep, the gates of, 268 .

Sloth, its drawbacks, 276. 
Small things beft difcover great, 1 ro.

Socrates, accufed of corrupting youth, 14 ; reaction in his favour when dead, 22; his uglinefs and goodnefs, 31 ; his irony, 52, 19I; called philofophy down from heaven, 54 ; his reply to Hippias, 110 ; charged with feparating philofophy and rhetoric, 160 ; his method of refutation, 198 ; wherein he placed true felicity, 238 ; difputes with a fophift, 244; quoted, $231,249,272,320$.

Solomon, his learning, 6o; his aphorifms on civil wifdom, 274, fq?

Solon's Laws, their wifdom, 27 ; his juft judgment as to

Crœfus' wealth, 302 .

Sophifm, the greateft, is equivocation, 199.

Sophifts compared with orators, 199.

Soul, nature of the, 178 ; not a proper fubject for invertigation, 179 .

spanifh proverb, 288.

Speech, an organ of tradition, 207.

Spirits in divers ranks, $5^{6}$; evil, not to be dealt with, though

their power may be enquired into, 136.

Standing-point for argument, men defire a, 197.

Statefinen, learned and experienced, compared, 66.

Stoics, their dogmas fitted to the fables of the poets by

Chryfippus, 129; their difpute with the Epicureans as to felicity lettled by Chriltianity, 238 ; feem to have difcuffed the affections well, 259.

Sturmius ftudied Cicero and Hermogenes, 37.

Suetonius not fo credible as Tacitus, I 59 .

Suffering, when wife, overcomes difficulties, 254.

Suggeftion, an inftrument of invention, I94.

Summaries of theology are bad, 323 .

Summary law of Nature, 145.

"Summum bonum," the, not to be difcuffed by us, 234 .

Superfitious narrations not always defpicable, 108 ; divination, $\mathbf{I} 79$.

Sun, the, is never defiled, fee what he may, rog.

Sylla, 180, 276 ; how judged by Cxar, 82 ; never con. demned fo many to die as phyficians do in their ignorance, 173 ; a troubler of the world, 242 ; modeft towards Fortune, ftyling himfelf Felix, not Magnus, 283 ; his aflumed franknefs, 299 .

Syllogifm, cannot invent arts, 190; Nature refufes to be enchained by it, $i b^{*}$; ufe of judgment in, $19^{6}$; in civil life the "minor premifes" the more important, 285 . 
Sympathies between body and mind difcufted, I6 1 , fqq.

Tacitus, 166, 229; on the eloquence of Auguftus, 3; his judgment on Nerva, 67 ; his annals, 119 ; his note on the retention of ancient terms and titles, 140 ; far more truftworthy than Suetonius, from the form of his narrative, 159 ; on fudden profperity, 257 ; obfervation on Tiberius and Agrippina, 288; on Tiberius' referved manners, 292; his judgment on Mutianus, 294; on Pompey's dark dealing, 300 ; on Livia, 301 .

Talk, the common, is fometimes wifer than books, 253 .

Tantalus, 310.

Tarquin buys the Sibyl's books, 298.

Telefius, 159.

Tennis gives quick eye and body, 151 .

Thales, I10.

Themiflocles, his faying as to mufic and government, 31 .

Theology, how divifible, 106 ; difcuffed briefly, 315 .

The feus, 114.

Thirty Tyrants, the, 22.

Thucydides on Cleon's hatred of eloquence, 222.

Tiberius concealed his power at firtt, 191 ; jealous of his heir, 276; clofett of men, 286, 292; his manner of fpeech, $i b$.; quarrels with Agrippina, 288.

Tigellinus intrigues againft Turpilianus, 290.

Time, the author of authors, 46 ; devours his children, 47 ; as a river, finks things weighty, and carries down what is light and worthlefs, 49 .

Timotheus, the Athenian, too arrogant towards fortune, 282.

Topics, not deficiently handled, 195 ; of two forts, $i b$.; the "particular" ones commended, 196; combine logic with fubject-matter, $i b$.

Tradition of knowledge, faulty, and a hindrance to learning, 51 ; art of, 206.

Trajan, though not learned, a patron of learning, 68; nicknamed "wall-flower" by Conftantine, 75 ; how praifed by Pliny, 266.

Travels, much multiplied of late, $12 \mathrm{I}$.

Treacle, 174.

Tribonian, 323 .

Trifagion of knowledge, 146.

Triumvirs, the, fold their friends to one another, 306 .

Truft and diftruft flowly, if you will make your fortune, 286. 
Truth of being and of knowing are one, 42 ; demands much feverity of inveftigation, $157,158$.

Tudor period of hiftory, 115,116 .

Tumblers and ropedancers can do with the body what "memoria technica" enables men to do with their minds, 206.

Turpilianus deftroyed through Tigellinus' intrigues, 290.

Uly Jes' judgment, 92 .

Union of England and Scotland, 117.

Univerfal propofitions in fciences, 219.

Univerfities to be cherifhed, 95 ; teach logic and rhetoric

to minds not ftored with fubject-matter (knowledge), 101 ; their exercifes faulty, 102; do not keep up fufficient intercourfe with one another, $i b$.

Untruth in learning, 42 .

Urbanity fometimes too much confidered, 272.

Valentine, Duke (Cælar Borgia), his cliaraeter, 292.

Valour, falfe, lies in the eyes of its beholders, I 9 .

Varro, belt of antiquaries, 22 .

Velleius, the epicurean, his impatience of doubt, 52 ; his queltion as to the ordering of ftars by God, inconfiftent with his principles, 202.

Verus, 压lius (fc. Ceionius Commodus), patron of Martial, $7 \mathrm{I}$; L. Commodus (fc. Aurelius), a learned prince, $i b$. Vibulenus, 229.

Virgil prejudiced againft learning, 13 ; beft of poets, 22 ; quoted, 85 ; lines on Auguftus, 87 ; got great glory by linging of humble matters, 233 .

Virtue, not to be undervalued, 295 ; is rewarded, 307 .

Vificins, prophetic, 180.

Vifitors of colleges, \&cc., neglectful, 100.

Vitality, how likely to be increafed, 154 .

Voluptuary arts flourifh moft in a decaying ftate, 178 .

Vulcan, god of alchemifts, 99, 137.

Whitenefs, the caufes of, 144 .

Wifdom, an attribute of God, 55; three kinds of, in civil life, 271, 273; true, compared with verbal, 279; of prudence, beft drawn from hiftory, 280 ; helps much towards felf-advancement, 282 .

Witchcraft, the height of idolatry, $\hat{3} 3 \hat{3}$.

Women judge by fortune rather than excellence, 278 . 


\section{INDEX .}

Wonder, feed of knowledge, is broken knowledge, 7 .

Word of God, the, 315.

Words, images of matter, 37 ; tokens of current notions of things, 190, 209 ; apt to impore on us, 203; of others, not to be unnoted, if you will build your fortune, 288 . World, the, wrongly judged to be an image of God, I 35 . Writing, art of, 204.

Xenophon, a general and fcholar, I 5,82 ; adorned philofophy with eloquence, 38 ; on the good effects of love, 267.

Young men not fit auditors of queltions of morals or policy, till their good habits are formed, 263 .

Zeñ, 237 . 



\section{Che Library of English Tatortbies.}

A Series of reprints of the best Authors carefully edited and collated with the Early Copies, and handsomely printed by Whittingham in Octavo.

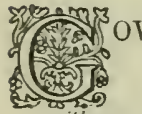

OWER'S Confessio Amantis, with Life by Dr. Pauli, and a Glossary. 3 rols. 2l. 2s. Antique calf, $3 l .6 s$. Only a limited number of Copies printed.

This important work is so scarce that it can seldom be met with eren in large libraries. It is wanting in nearly every collection of English Poctry.

Bishop Butler's Analogy of Religion; with Analytical Index, by the Rer. Edward Steere, LL.D. 12s. Antique calf, 1l. 1s.

"The present edition has been furnished with an Index of the Texts of Scripture quoted, and an Index of Words and Things considerably fuller than any hitherto published. These and the carefulness of the typography are small things in themselves perhaps, but he who ralues Butler at his true worth, will value any assistance in reading and referring to him."-Editor's Preface.

Bishop Jeremy Taylor's Rule and Exereises of Holy Living and Dring. 2 rols. Il. 1s. Antique calf, or moroceo, 2l. $2 s$.

Herbert's Poems and Remains; with S. T. Coleridge's Notes, and Life by Izaak Walton. Rerised, with additional Notes, by Mr. J. Yeorvell. 2 rols. 1l. 1s. Antique calf, or moroceo, 2l. $2 s$.

Spenser's Complete Works; with Life, Notes, and Glossary, by John Payne Collier, Esq., F.S.A.

[Shortly.

\section{Uniform with the above.}

The Physical Theory of Another Life. By Isaac Taylor, Esq., Anthor of "Logic in Theology," "Ultimate Civilization, \&c." New Edition. 10s, 6d. Antique calf, $21 s$.

\section{Cye Alane (E)ition of the Lititigh 3arts.}

G 3 KENSIDE'S Poetical Works, with Memoir by the Rev. A. Dyce, and additional Letters, carefully revised. 5s. Moroceo, or antique ealf, $10 s .6 d$.

Collins's Poems, with Memoir and Notes by W. Moy Thomas, Esq. 3s. $6 d$. Moroceo, or antique calf, $8 s .6 d$.

Gray's Poetical Works, with Notes and Memoir by the Rev. John Mitford. 5s. Morocco, or antique calf, 10s. $6 \mathrm{~d}$.

Shakespeare's Poems, with Memoir by the Rev. A. Dyce. $5 s$. Moroceo, or antique calf, 10s. $6 d$.

Young's Poems, with Memoir by the Rev. John Mitford, and additional Poems. 2 vols. 10s. II orocco, or antique calf, $1 l$. $1 s$.

Kirke White's Poems, with Memoir by Sir H. Nicolas, and additional notes. Carefully revised. $5 s$. Moroce or antique calf, 10s. $6 d$.

The general principle of Editing which has been adopted is to give the entire Poems of each author in strict conformity with the Edition which received his final revision, to prefix a Memoir, and to add such notes as may be necessary to elucidate the sense of obsolete words or explain obscure allusions. Each author will be placed in the hands of a competent editor specially aequainted with the literature and bibliography of the period. 


\section{Uniform with the Aldine Edition of the Poets.}

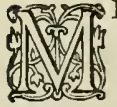

R. S. W. Singer's New Edition of Shakespeare's Dramatic Works. The Text carefully revised, with Notes. The Life of the Poet and a Critical Essay on each Play by W. W. Lloyd, Esq., MI.R.S.L. In 10 vols., price $6 s$. each. Calf, $5 l$. $5 s$. Morocco, 6l. $6 s$.

Large Paper Edition, erown 8ro., 4l. 10s. Calf, 6l. 16s, 6d. Morocco, 8l. 8s.

"Mr. Singer has produced a text, the accnracy of which cannot be surpassed in the present state of antiquarian and philological knowledge."Daily News.

The Works of Gray, edited by the Rev. John Mitford. With his Correspondence with Mr. Chute and others, Jonrnal kept at Rome, Criticism on the Seulptnres, \&ce. New Edition. 5 vols. $1 l .5 s$.

The Temple and other Poems. By George Herbert, with Coleridge's Notes. New Edition. 5s. Antiqne calf, or moroceo, 10s. $6 d$.

Vaughan's Sacred Poems and Pions Ejaculations, with Memoir by the Rer. H. F. Lyte. New Edition. 5s. Antique calf, or moroceo, 10s. 6d. Large Paper, 7s. 6d. Antique calf, 14s. Antique morocco, $15 s$.

"Preserving all the piety of George Herbert, they have less of his quaint and fantastic turns, with a mueh larger infusion of poetic feeling and expression."-Lyte.

Bishop Jeremy Taylor's Rule and Exercises of Holy Living and Holy Dying. $2 s .6 d$. each. Flexible morocco, $6 s .6 d$. each. Antique calf, 7s. 6d. each. Also in one volume, 5s. Antique calf, or moroceo, 10s. $6 d$.

Bishop Butler's Analogy of Religion; with Analytical Introduction and copious Index, by the Rev. Dr. Steere. 6s. Antique calf, 11s. 6d.

Bacon's Essays; or, Counsels Civil and Moral, with the Wisdom of the Ancients. With References and Notes by S. W. Singer, F.S.A. $5 s$. Morocco, or antique calf, $10 s .6 d$.

Bacon's Novum Organum. Newly translated, with short Notes, by the Rev. Andrew Johnson, M.A. 6s. Antiqne calf, 11s. $6 d$.

Locke on the Conduct of the Human Understanding; edited by Bolton Corney, Esq., M. R. S. L. $3 s .6 d$. Antique calf, $8 s .6 d$.

"I eanot think any parent or instruetor justified in neglecting to put this little treatise into the hands of a boy about the time when the reasoning faculties become developed."-Hallam.

Ultimate Civilization. By Isaac Taylor, Esq. $6 s$.

Logic in Theology, and other Essays. By Isaac Taylor, Esq. 6s.

The Physical Theory of Another Life. By Isaac Taylor, Esq., Author of the "Natural History of Enthusiasm," "Restoration of Belief," \&c. New Edition. 6s. Antique calf, 11s.6d.

\section{BELL \& DALDY, 186, FLEET STREET.}





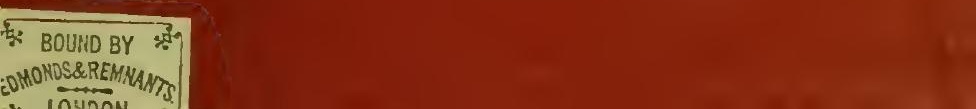


